MARIANA SEQUETIN CUNHA

Validação e uso de transcrição reversa seguida da reação em cadeia pela polimerase em tempo real (RT-qPCR) para a vigilância e diagnóstico de flavivírus transmitidos por mosquitos circulantes no Brasil

São Paulo

2018 
Validação e uso de transcrição reversa seguida da reação em cadeia pela polimerase em tempo real (RT-qPCR) para a vigilância e diagnóstico de flavivírus transmitidos por mosquitos circulantes no Brasil

Tese apresentada ao Programa de PósGraduação em Patologia Experimental e Comparada da Faculdade de Medicina Veterinária e Zootecnia da Universidade de São Paulo para a obtenção do título de Doutor em Ciências

Departamento:

Departamento de Patologia

Área de concentração:

Patologia Experimental e Comparada

Orientador:

Prof. Dr. Paulo César Maiorka

São Paulo 
Autorizo a reprodução parcial ou total desta obra, para fins acadêmicos, desde que citada a fonte.

DADOS INTERNACIONAIS DE CATALOGAÇÃO NA PUBLICAÇÃO

(Biblioteca Virginie Buff D'Ápice da Faculdade de Medicina Veterinária e Zootecnia da Universidade de São Paulo)

\begin{tabular}{|c|c|}
\hline $\begin{array}{l}\text { T. } 3618 \\
\text { FMVZ }\end{array}$ & $\begin{array}{l}\text { Cunha, Mariana Sequetin } \\
\text { Validação e uso de transcrição reversa seguida da reação em cadeia pela polimerase } \\
\text { em tempo real (RT-qPCR) para a vigilância e diagnóstico de flavivírus transmitidos por } \\
\text { mosquitos circulantes no Brasil / Mariana Sequetin Cunha. - } 2018 \text {. } \\
147 \mathrm{f} \text { : il. }\end{array}$ \\
\hline & $\begin{array}{l}\text { Tese (Doutorado) - Universidade de São Paulo. Faculdade de Medicina Veterinária e } \\
\text { Zootecnia. Departamento de Patologia, São Paulo, } 2018 .\end{array}$ \\
\hline & Programa de Pós-Graduação: Patologia Experimental e Comparada. \\
\hline & Área de concentração: Patologia Experimental e Comparada. \\
\hline & Orientador: Prof. Dr. Paulo César Maiorka. \\
\hline & 1. Flavivirus. 2. Vigilância. 3. RT-qPCR. I. Título. \\
\hline
\end{tabular}

Ficha catalográfica elaborada pela bibliotecária Camila Molgara Gamba, CRB 7070-8, da FMVZ/USP. 
CUNHA, M. S. Validação e uso de transcrição reversa seguida da reação em cadeia pela polimerase em tempo real (RT-qPCR) para a vigilância e diagnóstico de flavivírus transmitidos por

mosquitos circulantes no Brasil. 2018. $141 \mathrm{f}$. Tese (Doutorado em Ciências) - Faculdade de Medicina Veterinária e Zootecnia, Universidade de São Paulo, São Paulo, 2018.

Página

Ficha catalográfica

Resumo

Abstract

\section{Parágrafo}

$5^{\circ}$
Onde se lê

$147 \mathrm{f}$.
Leia-se

$141 \mathrm{f}$.
CUNHA, M. S. Validação e uso de transcrição reversa seguida da reação em cadeia pela polimerase em tempo real (RT-qPCR) para a vigilância e diagnóstico de flavivírus transmitidos por mosquitos circulantes no Brasil. 2018. 147 f. Tese (Doutorado em Ciências) - Faculdade de Medicina Veterinária e Zootecnia, Universidade de São Paulo, São Paulo, 2018.

CUNHA, M. S. Validation and use of reverse transcription followed by real-time polymerase chain reaction ( $R T-q P C R)$ for the surveillance and diagnosis of flavivirus transmitted by mosquitoes in Brazil. [Validação e uso de transcrição reversa seguida da reação em cadeia pela polimerase em tempo real (RT-qPCR) para a vigilância e diagnóstico de flavivírus transmitidos por mosquitos circulantes no Brasil]. 2018. $147 \mathrm{f}$. Tese (Doutorado em Ciências) - Faculdade de Medicina Veterinária e Zootecnia, Universidade de São Paulo, São Paulo, 2018.
CUNHA, M. S. Validação e uso de transcrição reversa seguida da reação em cadeia pela polimerase em tempo real (RT-qPCR) para a vigilância e diagnóstico de flavivírus transmitidos por mosquitos circulantes no Brasil. 2018. $141 \mathrm{f}$. Tese (Doutorado em Cièncias) - Faculdade de Medicina Veterinária e Zootecnia, Universidade de São Paulo, Săo Paulo, 2018.

CUNHA, M. S. Validation and use of reverse transcription followed by realtime polymerase chain reaction (RT. qPCR) for the surveillance and diagnosis of tlavivirus transmitted by mosquitoes in Brazil. [Validação e uso de transcrição reversa seguida da reação em cadeia pela polimerase em tempo real (RT-qPCR) para a vigilància e diagnóstico de flavivirus transmitidos por mosquitos circulantes no Brasil]. 2018. $141 \mathrm{f}$. Tese (Doutorado em Ciências) - Faculdade de Medicina Veterinária e Zootecnia, Universidade de São Paulo, São Paulo, 2018. 


\section{CERTIFIED}

We certify that the Research "Validation and use of real-time RT-PCR for the surveillance and diagnosis of flavivirus transmitted by circulating mosquitoes in Brazil.", protocol number CEUAx 5400050214, under the responsibility Paulo César Maiorka, agree with Ethical Principles in Animal Research adopted by Ethic Committee in the Use of Animals of School of Veterinary Medicine and Animal Science (University of São Paulo), and was approved in the meeting of day January 29, 2018.

Certificamos que o protocolo do Projeto de Pesquisa intitulado "Validação e uso de RT-PCR em tempo real para a vigilância e diagnóstico de flavivírus transmitidos por mosquitos circulantes no Brasil.", protocolado sob o CEUAx no 5400050214, sob a responsabilidade de Paulo César Maiorka, está de acordo com os princípios éticos de experimentação animal da Comissão de Ética no Uso de Animais da Faculdade de Medicina Veterinária e Zootecnia da Universidade de São Paulo, e foi aprovado na reunião de 29 de janeiro de 2018.

$$
\text { Mnneliese Teala. }
$$

Profa. Dra. Anneliese de Souza Traldi Presidente da Comissão de Ética no Uso de Animais Faculdade de Medicina Veterinária e Zootecnia da Universidade de São Paulo

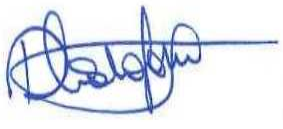

Roseli da Costa Gomes

Secretária Executiva

Faculdade de Medicina Veterinária e Zootecnia da Universidade de São Paulo 
Autor: CUNHA, Mariana Sequetin

Título: Validação e uso de transcrição reversa seguida da reação em cadeia pela polimerase em tempo real (RT-qPCR) para a vigilância e diagnóstico de flavivírus transmitidos por mosquitos circulantes no Brasil

Tese apresentada ao Programa de PósGraduação em Patologia Experimental e Comparada da Faculdade de Medicina Veterinária e Zootecnia da Universidade de São Paulo para obtenção do título de Doutor em Ciências

Data:

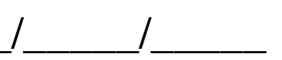

\section{Banca Examinadora}

Prof. Dr.

Instituição: Julgamento:

Prof. Dr.

Instituição: Julgamento:

Prof. Dr. Instituição: Julgamento:

Prof. Dr. Instituição: Julgamento:

Prof. Dr. Instituição: Julgamento: 


\section{DEDICATÓRIA}

Dedico esta humilde tese à minha família, pelo total apoio à minha carreira desde seu início: meus pais, Newton Oliveira da Cunha e Elenice Maria Sequetin Cunha, e meu irmão, Bruno Sequetin Oliveira da Cunha, e aos meus avós (in memorian): Angelina Daglio Sequetin, José Cechetim, Maria Conceição Oliveira da Cunha e Jeosua da Cunha, tendo a certeza de vosso apoio e orgulho. Dedico, ainda, ao meu querido "anexo", Ricardo Domingues Martins Parra, pela amizade, paciência, apoio e compreensão nesses anos.

Fica aqui esta singela homenagem para as grandes pessoas que me iluminam nesta jornada. 


\section{AGRADECIMENTOS}

Meus sinceros agradecimentos a todos que colaboraram de alguma forma para que este projeto fosse possível:

Ao meu orientador, Prof. Dr. Paulo César Maiorka, pela confiança, convite e aceite da orientação do presente trabalho;

À Dra. Fabiana Cristina Pereira de Sousa, do NDTV, pela amizade, dedicação, conhecimento repassado e pelo apoio indispensável a este trabalho;

À Dra. Adriana Luchs, do NDE, pela amizade e parceria, pelas reações de sequenciamento, pelos congressos frequentados, risadas, conversas e incentivo, sem os quais este trabalho seria muito difícil de ser realizado;

Ao Prof. Dr. Maurício Lacerda Nogueira, da FAMERP, pela amizade, conversas e sugestões, e também pela ajuda quando tive dúvidas;

À PqC. VI Terezinha Lisieux Moraes Coimbra, pelo carinho, apoio e isolamento dos vírus utilizados neste trabalho;

À PqC. VI Akemi Suzuki, pelas coletas e identificação dos mosquitos, e pelo seu apoio quando diretora do NDTV para que eu iniciasse este projeto;

À PqC. VI Iray Maria Rocco, pelo apoio, amizade e ajuda com a inoculação em células;

À PqC. VI Áurea Silveira Cruz Garçon, do NCC, e aos demais funcionários do núcleo pelo fornecimento das culturas celulares utilizadas;

Ao Dr. Renato Pereira de Sousa, diretor técnico do NDTV, pelas sugestões e pelo apoio para o término do projeto;

À Milena de Oliveira, secretária do VPT, pela ajuda; 
A Antônio Herculiane Júnior, do Centro de Virologia, pela colaboração no sequenciamento das amostras;

Aos meus colegas do NDTV, pela ajuda e apoio;

À FAPESP, pelo auxílio financeiro deste projeto $\left(\mathrm{n}^{\circ} 2012 / 23645-4\right)$

A toda minha família e meus amigos. 
A vida é breve, a arte é longa, a ocasião, fugidia, o experimento, perigoso, o juízo, difícil. Hipócrates 


\section{RESUMO}

CUNHA, M.S. Validação e uso de transcrição reversa seguida da reação em cadeia pela polimerase em tempo real (RT-qPCR) para a vigilância e diagnóstico de flavivírus transmitidos por mosquitos circulantes no Brasil. [Validation and use of reverse transcription followed by real-time polymerase chain reaction (RT-qPCR) for the surveillance and diagnosis of flavivirus transmitted by mosquitoes in Brazil]. 2018. 147 f. Tese (Doutorado em Ciências) - Faculdade de Medicina Veterinária e Zootecnia, Universidade de São Paulo, São Paulo, 2018.

Os flavivírus são considerados uma séria ameaça à saúde pública em diversas partes do mundo, pois muitos são agentes altamente patogênicos a seres humanos e animais, tais como os vírus da febre amarela, vírus do Oeste do Nilo, vírus da encefalite japonesa e vírus da dengue, capazes de causar encefalites ou febres hemorrágicas em seus hospedeiros. Muitos deles têm avançado a diferentes regiões geográficas onde sua circulação não havia sido detectada previamente, causando novos surtos. O diagnóstico clínico destas infecções é, muitas vezes, difícil, devido ao grande número de sintomas apresentados, que podem se confundir com outras enfermidades de diferentes causas etiológicas. Os principais métodos diretos utilizados atualmente no Brasil para detecção destes vírus são a inoculação intracerebral em camundongos neonatos, inoculação em culturas de células e RTPCR específica. O presente trabalho tem como objetivos avaliar a sensibilidade e validar a detecção dos vírus pertencentes ao gênero Flavivirus circulantes no Brasil por meio de uma reação single de RT-PCR em tempo real e implementá-la, tanto na rotina diagnóstica de casos com suspeita de arbovirose como na pesquisa de amostras de campo para monitoramento viral. Amostras dos flavivírus padrões da Febre Amarela, Bussuquara, Iguape, Ilheus, Encefalite de Saint Louis, Cacipacore e Zika foram quantificados por titulação em unidades formadoras de placa (UFP) ou TCID50 para se avaliar os limites de detecção para cada um deles por RT-qPCR que detecta o gênero Flavivirus. Os limites encontrados variaram de 0,01 UFP, para

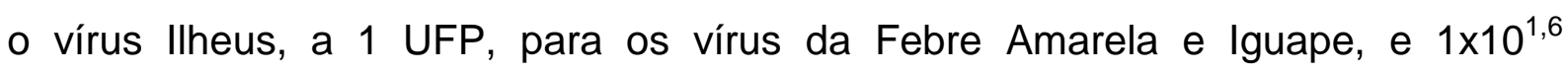

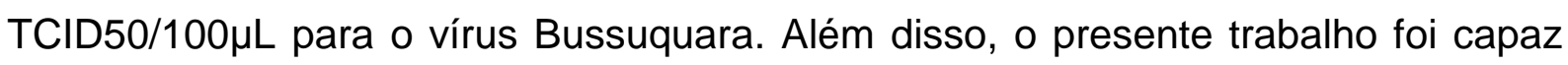
de identificar, após sequenciamento de cDNA gerado, os vírus Zika, isolado de um paciente febril, e os vírus Ilheus e Iguape, isolados a partir de diferentes espécies de Culicídeos, após uma única reação de RT-qPCR, e um possível novo flavivírus 
específico de insetos, isolado de mosquitos Aedes coletados em Guapiaçu, São Paulo. Não houve sinal de amplificação para os Alphavirus Mayaro e Chikungunya. O presente protocolo mostrou-se com alta sensibilidade e especificidade, podendo dessa forma ser utilizado para o diagnóstico diferencial dos diferentes flavivírus que ocorrem no Brasil, bem como para estudos de monitoramento viral em animais sentinelas e vetores, colaborando dessa forma com a saúde pública. Pode-se, ainda, detectar possíveis novos vírus específicos de artrópodes.

Palavras-chave: Flavivirus. Vigilância. RT-qPCR. 


\begin{abstract}
CUNHA, MS. Validation and use of reverse transcription followed by real-time polymerase chain reaction (RT-qPCR) for the surveillance and diagnosis of flavivirus transmitted by mosquitoes in Brazil. [Validação e uso de transcrição reversa seguida da reação em cadeia pela polimerase em tempo real (RTqPCR) para a vigilância e diagnóstico de flavivírus transmitidos por mosquitos circulantes no Brasil]. 2018. 147 f. Tese (Doutorado em Ciências) - Faculdade de Medicina Veterinária e Zootecnia, Universidade de São Paulo, São Paulo, 2018.
\end{abstract}

Flaviviruses are considered a serious threat to public health in many parts of the world, as many are highly pathogenic to humans and animals, such as Yellow Fever virus, West Nile virus, Japanese encephalitis virus and dengue virus, which are capable of causing encephalitis or hemorrhagic fever in their hosts. Many of them have spread to different geographic regions where their circulation had not been detected previously, causing new outbreaks. Diagnosis of these infections is often difficult, due to the large number of symptoms presented, which can be confused with other diseases of different etiological causes. The main direct methods currently used in Brazil for detecting these viruses are intracerebral inoculation in neonatal mice, inoculation in cell cultures and specific RT-PCR. The present work aims to evaluate the sensitivity and validate the detection of viruses belonging to the genus Flavivirus circulating in Brazil through a single real-time RT-PCR reaction and to implement it, both in the diagnostic routine of cases with arbovirus suspicions and in field samples for viral monitoring. Samples of the standard flaviviruses Yellow Fever, Bussuquara, Iguape, Ilheus, Saint Louis Encephalitis, Cacipacore and Zika were quantified by titration by plaque forming units (UFP) or TCID50 to evaluate the detection limits for each of them by RT- qPCR that detects genus Flavivirus. The limits found ranged from 0.01 PFU for Ilheus virus to 1 PFU for Yellow Fever and Iguape viruses and $1 \times 10^{1.6}$ TCID50 / 100 $\mathrm{L}$ for the Bussuquara virus. In addition, the present work was able to identify, after cDNA sequencing Zika virus, isolated from a febrile patient, and both Ilheus and Iguape viruses, isolated from different species of Culicidae, and a possible new insect-specific flavivirus, isolated from Aedes mosquitoes collected in Guapiaçu, São Paulo. The Alphaviruses Mayaro and Chikungunya were not amplified. The present protocol shoed high sensitivity and specificity, and therefore it may may be used for the differential diagnosis of the 
different flaviviruses that occur in Brazil, as well as for viral monitoring studies in sentinel animals and vectors, thus collaborating with public health. It is also possible to detect new flavivirus that are arthopode-specific.

Keywords: Flavivirus. Surveillance RT-qPCR. 


\section{LISTA DE FIGURAS}

Figura 1- Organização do genoma e da poliproteína dos membros do gênero Flavivirus, indicando as proteínas estruturais e não estruturais geradas após processo proteolítico.........................................................30

Figura 2 - Rede de laboratórios brasileiros macro-regionais .57

Figura 3 - Placas formadas por Vírus Zika SPH341957 em células Vero 62

Figura 4 - Efeito citopático observado em células Vero causado por Flavivírus. 63

Figura 5 - Reação de imunofluorescência indireta positiva, utilizando-se células C6/36

Figura 6- Perfil linear da absorbância emitida durante cada ciclo no protocolo da curva de concentração decrescente para o protocolo de RT-qPCR para o vírus vacinal da Febre Amarela, utilizando-se os primers Flavi all S e Flavi all AS2, com sonda Flavi all 3. Estão incluídas 3 plicatas para as diluições do vírus, de 10-1 a 10-8. Registro de resultado de experimento interpretado pelo software $A B I$ StepOne v2.3 .74

Figura 7- Perfil linear da absorbância emitida durante cada ciclo no protocolo da curva de concentração decrescente para o protocolo de RT-qPCR para 0 vírus Ilheus, utilizando-se os primers Flavi all S e Flavi all AS2, com sonda Flavi all 3. Estão incluídas 2 plicatas para as diluições do vírus, de 10-1 a 10-8. Registro de resultado de experimento interpretado pelo software ABI StepOne v2.3.

Figura 8- Perfil linear da absorbância emitida durante cada ciclo no protocolo da curva de concentração decrescente para o protocolo de RT-qPCR para 
o vírus da Encefalite de Saint Louis, utilizando-se os primers Flavi all S e Flavi all AS2, com sonda Flavi all. Estão incluídas 2 plicatas para as diluições do vírus, de $10^{-1}$ a $10^{-8}$. Registro de resultado de experimento interpretado pelo software ABI StepOne v2.3.

Figura 9- Perfil linear da absorbância emitida durante cada ciclo no protocolo da curva de concentração decrescente para o protocolo de RT-qPCR para o vírus Zika, utilizando-se os primers Flavi all S e Flavi all AS2, com sonda Flavi all 3. Estão incluídas 4 plicatas para as diluições do vírus, de $10^{-1}$ a $10^{-8}$. Registro de resultado de experimento interpretado pelo software $A B I$ StepOne v2.3. .79

Figura 10- Perfil linear da absorbância emitida durante cada ciclo no protocolo da curva de concentração decrescente para o protocolo de RT-qPCR para o vírus Iguape, utilizando-se os primers Flavi all S e Flavi all AS2, com sonda Flavi all 3. Estão incluídas 3 plicatas para as diluições do vírus, de $10^{-1}$ a $10^{-8}$. Registro de resultado de experimento interpretado pelo software ABI StepOne v2.3. .81

Figura 11- Perfil linear da absorbância emitida durante cada ciclo no protocolo da curva de concentração decrescente para o protocolo de RT-qPCR para o vírus Cacipacore, utilizando-se os primers Flavi all S e Flavi all AS2, com sonda Flavi all 3. Estão incluídas 3 plicatas para as diluições do vírus, de $10^{-1}$ a $10^{-8}$. Registro de resultado de experimento interpretado pelo software $A B I$ StepOne v2.3. .83

Figura 12- Perfil linear da absorbância emitida durante cada ciclo no protocolo da curva de concentração decrescente para o protocolo de RT-qPCR para o vírus Bussuquara, utilizando-se os primers Flavi all S e Flavi all AS2, com sonda Flavi all 3. Estão incluídas 3 plicatas para as diluições do vírus, de $10^{-1}$ a $10^{-8}$ Registro de resultado de experimento interpretado pelo software $A B I$ StepOne v2.3 .85 
Figura 13- Alinhamento de fragmento 1360 pares de base da NS5 gerado dos isolados SPARFlavi01 e SPARFlavi02 com demais vírus específicos de insetos recuperados do GenBanK

Figura 14- Árvore filogenética (nucleotídeos) do vírus llheus para a região parcial da NS5 gerada por meio do método de Máxima Parcimônia baseada no modelo Kimura 2-parâmetro. Os números próximos a cada nó representam os valores de 1000 repetições de bootstrap. A escala representa o número de substituições/sítio

Figura 15- Árvore filogenética (nucleotídeos) de Flavivirus isolado a partir de mosquitos do gênero Aedes para a região parcial de 1374 nt da NS5 gerada por meio do método de Máxima Parcimônia baseada no modelo Kimura 2-parâmetro. Os números próximos a cada nó representam os valores de 1000 repetições de bootstrap. A escala representa o número de substituições/sítio. Estão representados na figura valores acima de 70 .94

Figura 16- Árvore filogenética (aminoácidos) de Flavivirus isolado a partir de mosquitos do gênero Aedes para a região parcial de 1374 nt da NS5 gerada por meio do método de Máxima Parcimônia baseada no modelo JTT. Os números próximos a cada nó representam os valores de 1000 repetições de bootstrap. A escala representa o número de substituições/sítio. Estão representaos na figura valores acima de 70 


\section{LISTA DE TABELAS}

Tabela 1- Vírus utilizados no presente estudo, fonte, passagem e data. .58

Tabela 2 - Amostras inoculadas em camundongos neonatos, com possível isolamento positivo para arbovírus, provenientes de mosquitos capturados pelo NDTV. 59

Tabela 3 - Relação de amostras encaminhadas ao NDTV para diagnóstico ou monitoramento viral.

Tabela 4 - Sequência e posição de anelamento dos oligoiniciadores utilizados no estudo. 66

Tabela 5 - Oligoiniciadores descritos por Kuno et al. (1998a) utilizados para confirmação de flavivírus isolados a partir de mosquitos Aedes sp. capturados no município de Guapiaçu em 2017

Tabela 6 - Relação de vírus usados na construção de árvores filogenéticas do presente estudo, e seus números de acesso no GenBank.

Tabela 7- Títulos obtidos para cada flavivírus usado no presente estudo. .73

Tabela 8- Médias dos valores de Ct obtidos através de reação de RT-qPCR utilizando-se os primers Flavi all S e Flavi all AS2, com sonda Flavi all 3 para cada dilução dos flavivírus usados no presente estudo e respectivos valores da eficiência de cada reação. .86 
Tabela 9- Comparação dos resultados dos limites de deteç̧ão para cada um dos flavivírus utilizados no presente estudo em diferentes técnicas, demonstrados em unidades formadoras de placa por

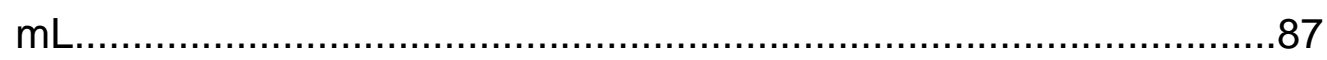

Tabela 10 - Valores de Ct obtidos através de reação de RT-qPCR utilizando-se os pares de iniciadores descritos por DOMINGO et al., 2012 (VFA); DYER; CHISENHALL; MORES, 2007 (VESL) e LANCIOTTI et al., 2008 (VZIK) .87

Tabela 11- Flavivírus identificados no presente estudo após reação de RT-qPCR seguida de sequenciamento utilizando-se os primers Flavi all S e Flavi all AS 2 e sonda Flavi all 3, com análise de nucleotídeos utilizando-se a ferramenta BLAST. 88 


\section{LISTA DE GRÁFICOS}

Gráfico 1- Curva padrão de eficiência para o protocolo de RT-qPCR para o vírus vacinal da Febre Amarela, utilizando-se os primers Flavi all S e Flavi all AS2, com sonda Flavi all 3. Para o cálculo da mesma, foram selecionados 6 pontos com 3 repetições. Registro de resultado de experimento interpretado pelo software ABI StepOne v2.3..................74

Gráfico 2- Curva padrão de eficiência para o protocolo de RT-qPCR para o vírus Ilheus, utilizando-se os primers Flavi all S e Flavi all AS2, com sonda Flavi all 3. Para o cálculo da mesma, foram selecionados 6 pontos com 2 repetições. Registro de resultado de experimento interpretado pelo software ABI SteOne v2.3......................................................... 76

Gráfico 3- Curva padrão de eficiência para o protocolo de RT-qPCR para o vírus da Encefalite de Saint Louis, utilizando-se os primers Flavi all S e Flavi all AS2, com sonda Flavi all. 3 Para o cálculo da mesma, foram selecionados 5 pontos com 3 repetições. Registro de resultado de experimento interpretado pelo software $A B I$ StepOne v2.3. .78

Gráfico 4- Curva padrão de eficiência para o protocolo de RT-qPCR para o vírus Zika, utilizando-se os primers Flavi all S e Flavi all AS2, com sonda Flavi all 3. Para o cálculo da mesma, foram selecionados 5 pontos com 3 repetições. Registro de resultado de experimento interpretado pelo software ABI StepOne v2.3. 80

Gráfico 5- Curva padrão de eficiência para o protocolo de RT-qPCR para o vírus Iguape, utilizando-se os primers Flavi all S e Flavi all AS2, com sonda Flavi all 3. Para o cálculo da mesma, foram selecionados 5 pontos com 3 repetições. Registro de resultado de experimento interpretado pelo software $\mathrm{ABI}$ StepOne v2.3. 82 
Gráfico 6- Curva padrão de eficiência para o protocolo de RT-qPCR para o vírus Cacipacore, utilizando-se os primers Flavi all S e Flavi all AS2, com sonda Flavi all 3. Para o cálculo da mesma, foram selecionados 6 pontos com 3 repetições. Registro de resultado de experimento interpretado pelo software ABI StepOne v2.3....................................84 


\section{SUMÁRIO}

1 INTRODUÇÃO

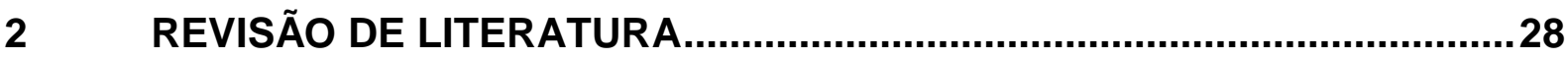

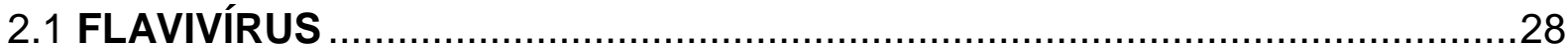

2.2 GENOMA E REPLICAÇÃO

2.3 DINÂMICA VIRAL NA INFECÇÃO DE MOSQUITOS …...............................

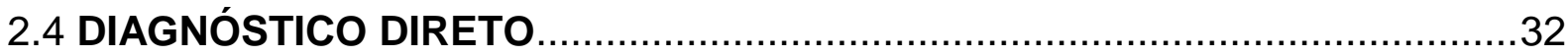

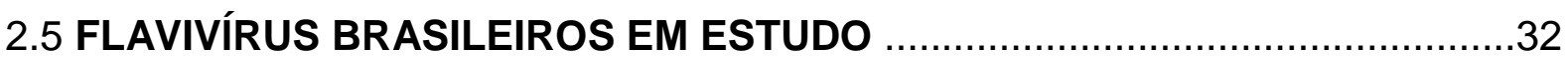

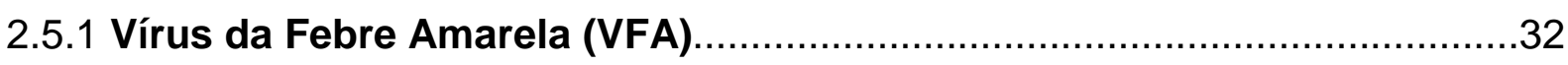

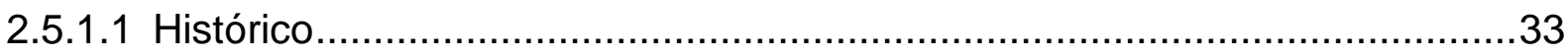

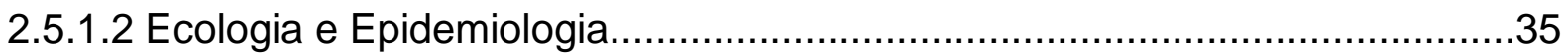

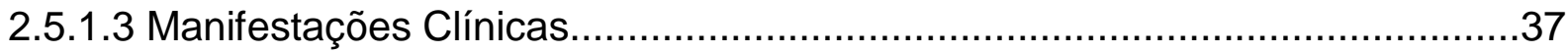

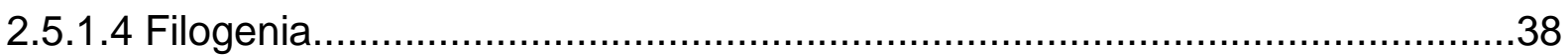

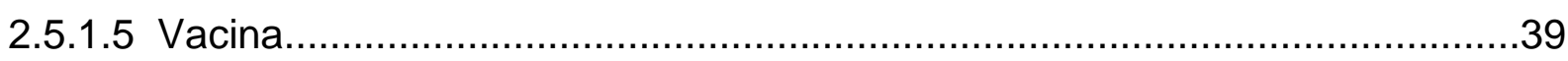

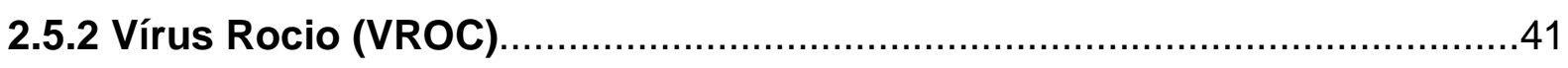

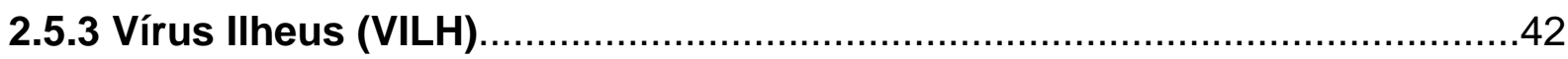

2.5.4 Vírus da Encefalite de Saint Louis (VESL) ...........................................

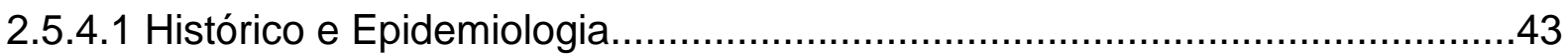

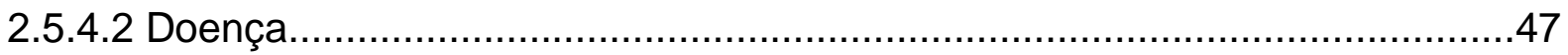

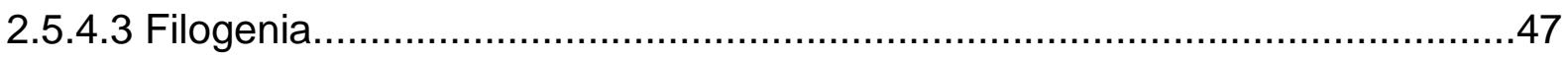

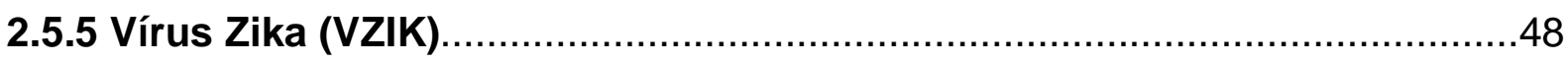

2.5.5.1 Epidemiologia e Histórico................................................... 48

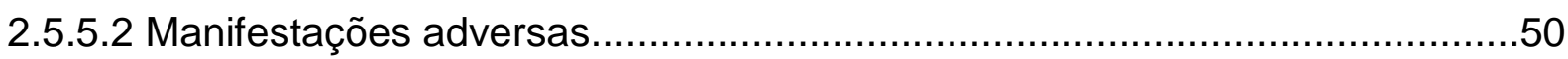

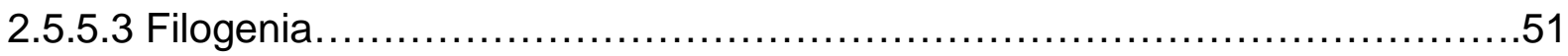

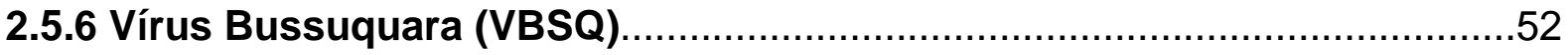

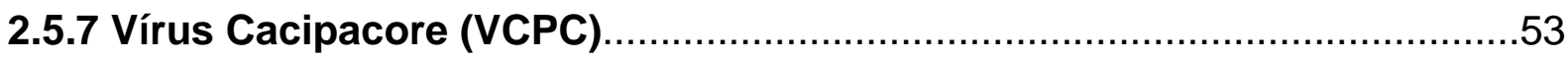

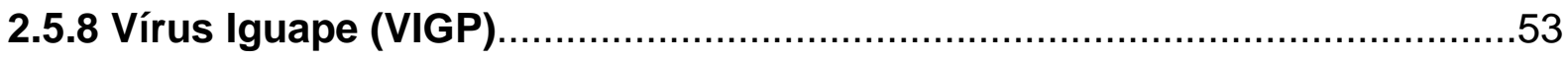

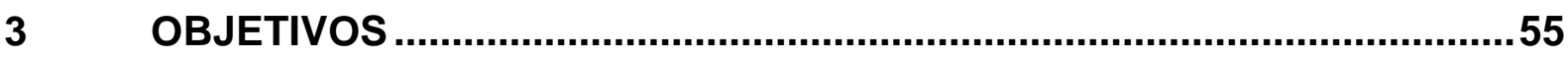

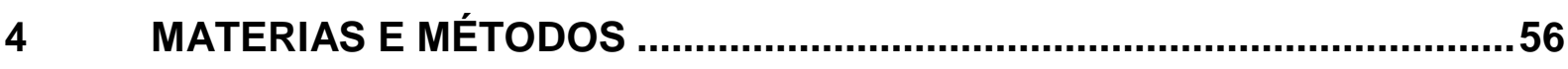

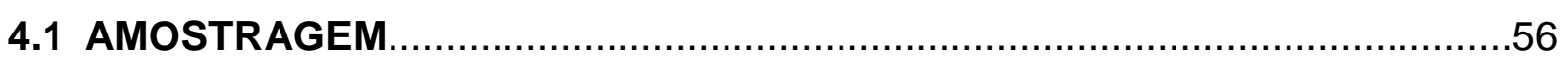

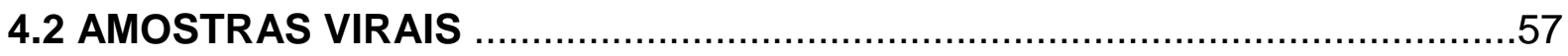

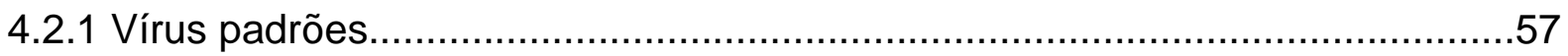


4.2.2 Amostras testadas a partir de mosquitos coletados pelas equipes de campo do NDTV .58

4.2.3 Amostras enviadas ao NDTV pela rede ou por demais órgãos. .59

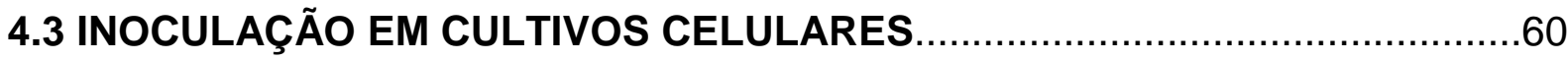

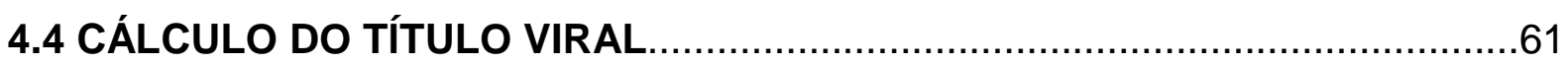

4.4.1 Titulação por Unidade Formadora de Placa (UFP).......................................61

4.4.2 Titulação por Dose Infectante por cultura de Tecido 50\% (TCID50).................62

4.5. INOCULAÇÃO EM CÉLULAS C6/36 SEGUIDA DE IMUNOFLUORESCÊNCIA

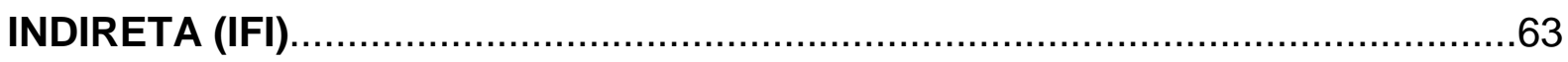

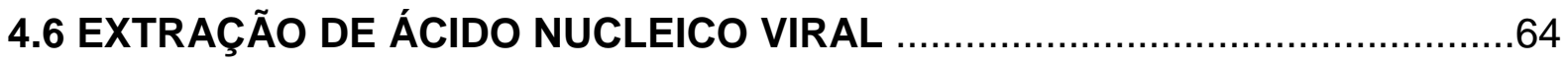

4.7 TRANSCRIÇÃO REVERSA SEGUIDA DA REAÇÃO EM CADEIA PELA

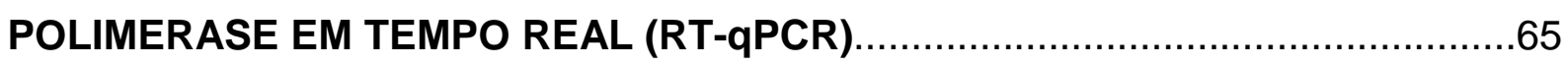

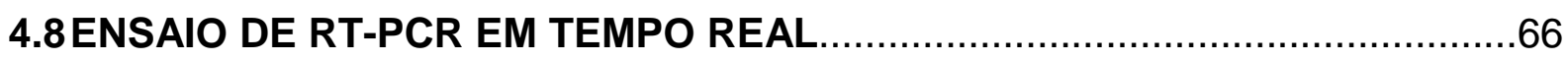

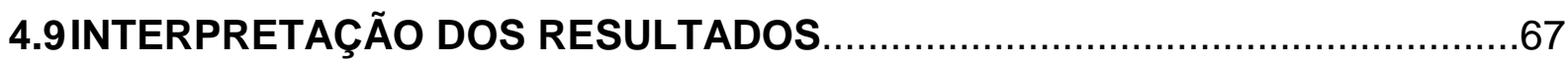

4.10 VALIDAÇÃO DOS ENSAIOS DE RT-QPCR E ANÁLISE ESTATÍSTICA........67

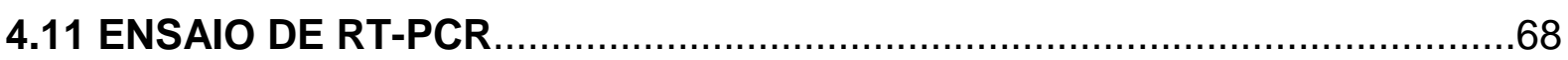

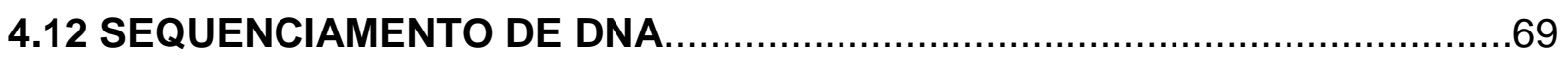

4.13 PURIFICAÇÃO E PRECIPITAÇÃO DO PRODUTO DA REAÇÃo DE

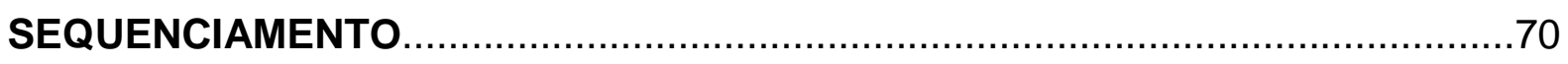

4.14 ANÁLISE DAS SEQUÊNCIAS E FILOGENIA .............................................

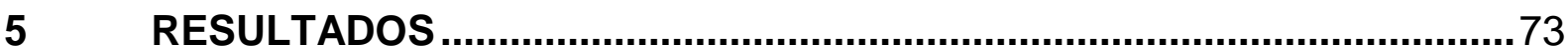

5.1 TITULAÇÃO

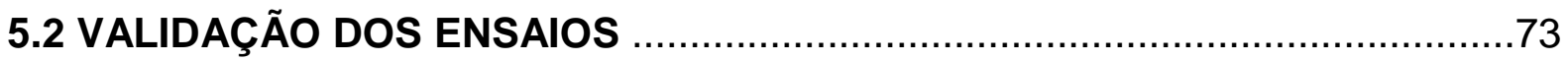

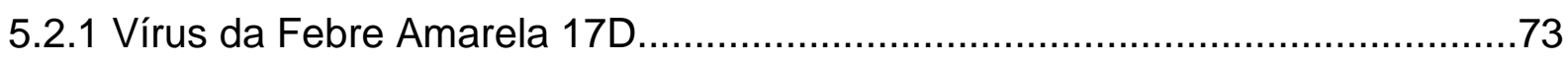

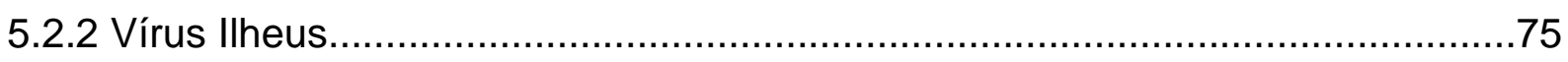

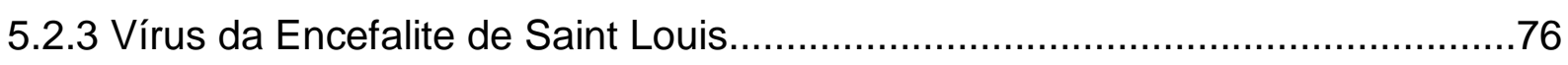

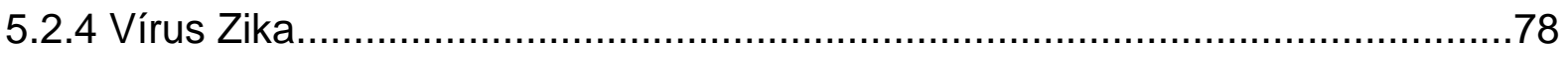

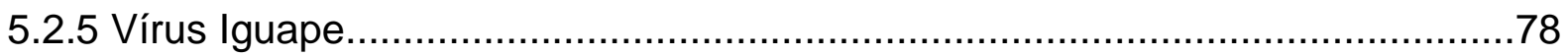

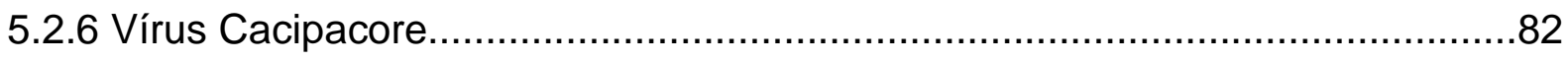

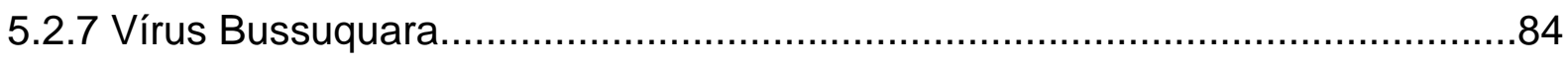

5.3 EFICIÊNCIA E LIMITES DE DETECÇÃO

5.4 COMPARAÇÃO DA DETECÇÃO COM OUTRAS METODOLOGIAS...............86

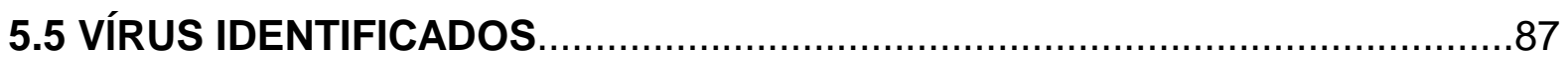


5.6 FILOGENIA

6 DISCUSSÃO

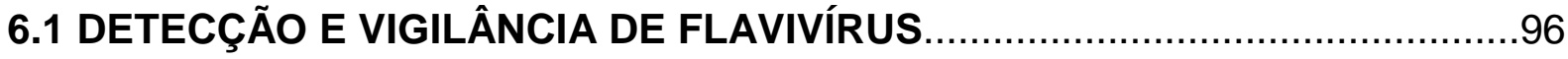

6.2 USO DA RT-QPCR PARA DIAGNÓSTICO DIFERENCIAL DE FLAVIVÍRUS .......................................................................... 102

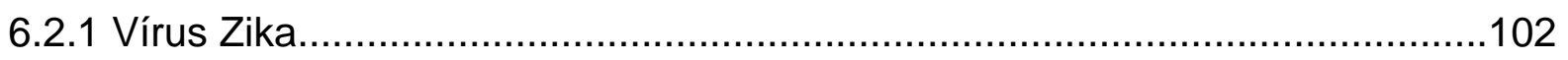

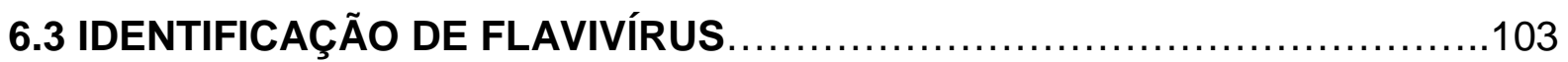

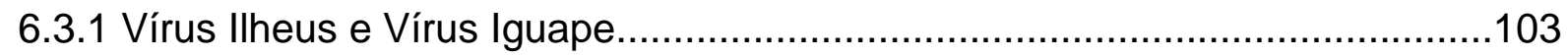

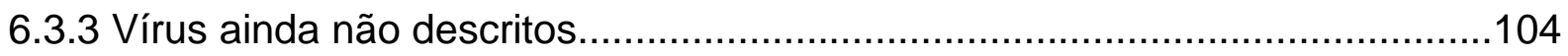

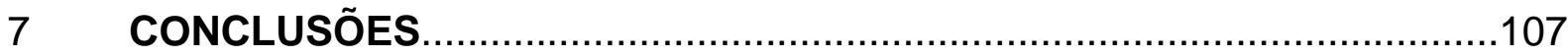

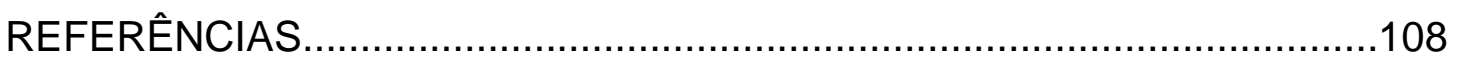

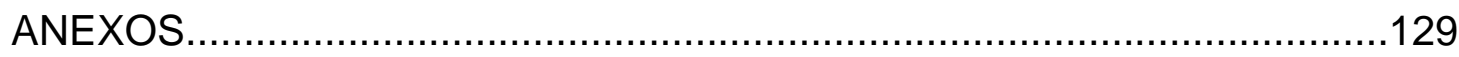




\section{INTRODUÇÃO}

Doenças causadas por arbovírus (que deriva do inglês arthropod-borne viruses) são aquelas transmitidas às pessoas através da picada de um artrópode infectado. De forma geral, pouca prioridade foi dada à pesquisa nessa área. Durante os últimos 50 anos, no entanto, a emergência de alguns arbovírus alterou a percepção de sua importância na Saúde Pública, graças à alta letalidade e/ou morbidade que eles causam mundialmente (GUBLER; CLARK, 1995). A disseminação de vários agentes virais tem ocorrido de forma progressiva desde o final do século $X X$ e início do $X X I$, resultando em novas áreas de distribuição dos vírus, possíveis novos vetores e novas manifestações clínicas, tanto em seres humanos quanto em animais. Tem-se como exemplos, no início do século XXI, a rápida expansão mundial o vírus Zika, que foi declarado como emergência em saúde global pela Organização Mundial de Saúde (OMS) em 2016. Neste mesmo ano, o vírus da Febre Amarela teve seu primeiro caso importado em viajantes internacionais confirmado laboratorialmente na Ásia, colocando 1,8 bilhões de pessoas não vacinadas em risco, graças à presença do vetor urbano Aedes aegypti (MONATH et al., 2017). O vírus do Oeste do Nilo foi introduzido em 1999 nos Estados Unidos da América, expandindo-se rapidamente para as Américas do Norte e do Sul em poucos anos (ARTSOB et al., 2009). Da mesma forma que os flavivírus anteriores, o vírus da Encefalite Japonesa disseminou-se pelo oeste, norte e sul asiático (MACKENZIE; GUBLER; PETERSEN, 2004).

Dentre os principais arbovírus patogênicos de ocorrência no país, temos os pertencentes aos gêneros Flavivirus, Alphavirus (família Togaviridae) e Orthobunyavirus (família Bunyaviridae), que apresentam diferenças em seus ciclos de transmissão, reservatórios e vetores, sendo exemplos os vírus Mayaro, Chikungunya e vírus das Encefalites Equinas (Alphavirus) e Oropouche e Caraparu (Bunyavirus). Nesse contexto, tem-se o gênero Flavivirus como principais agentes causadores de tais infecções no Brasil. Estes pertencem à família Flaviviridae, que são vírus envelopados de RNA fita simples, classificados em complexos antigênicos e subcomplexos, baseados em critérios sorológicos clássicos ou em clusters, clados 
e espécies, de acordo com estudos de filogenia molecular epidemiológicos distintos: vírus neurotrópicos, geralmente associados a casos de encefalite em humanos e/ou animais de produção, que têm como vetores Culex spp. e pássaros como reservatórios, e os não neurotrópicos, associados a doenças hemorrágicas em humanos, com Aedes spp. como vetores e hospedeiros primatas (GAUNT et al., 2001). Dessa forma, vírus do complexo antigênico da Encefalite Japonesa foram isolados de diversos vetores, porém são mais comumente associados a mosquitos do gênero Culex, enquanto que dentre os não neurotrópicos, como vírus Dengue e vírus da Febre Amarela, estes são predominantemente transmitidos pelo Aedes aegypti (GUBLER, 1988; TAYLOR, 1951).

Os seres humanos vêm causando sérias alterações no ecossistema, como fragmentações em habitats naturais, aquecimento global e exploração de recursos naturais sem controle, o que proporcionou um maior contato entre eles e diversos patógenos transmitidos por artrópodes. Visando, então, uma diminuição desse risco, e também minimizar o impacto dessas doenças para as populações humana e animal, foi criado o Plano Estratégico Global para Saúde. Tais doenças revelam a importância do conceito da Saúde Única (One Health) (FRANK, 2008), o qual reconhece que a saúde dos seres humanos está ligada com a saúde dos animais daquele ambiente compartilhado. Trata-se de uma aproximação colaborativa, multissetorial e transdiciplinar, que tem o objetivo de obter resultados ótimos de saúde, reconhecendo a interconexão entre pessoas, animais, plantas o e ambiente. Como parte desse programa, sugeriu-se o uso de políticas de vigilância em animais, contribuindo dessa forma para a manutenção da saúde humana, envolvendo médicos, ecologistas e veterinários no controle de tais ameaças à Saúde Pública (SHAFFER, 2008).

Existem inúmeros testes para o sorodiagnóstico destes vírus usados atualmente, dos quais podemos citar o Teste de Inibição da Hemaglutinação $(\mathrm{IH})$, que é baseado na capacidade viral de agregar eritrócitos de certos animais, avaliando dessa forma a existência de imunoglobulinas das classes $\lg G$, $\lg M$ e $\lg A$ (KUNO, 2003). Testes de neutralização são uma outra ferramenta para tal, que identificam imunoglobulinas neutralizantes, incluindo $\lg \mathrm{e} \lg \mathrm{M}$, com boa especificidade (ISHII; MATSUNAGA; KONO, 1968). Dentre eles, o mais utilizado é o 
Teste de Neutralização por Redução de Placa. Além destes, há atualmente uma gama de imunoensaios enzimáticos, em particular testes ELISA, que variam desde o tipo e de anticorpo detectado até o tipo do teste, podendo ser comerciais ou não (KUNO, 2003). A detecção de anticorpos pode distinguir alguns deles, mas, considerando exposições prévias a flavivírus relacionados, principalmente em um país tropical endêmico, com ciclos epidemiológicos silvestres complexos, tais testes, como o ELISA IgM e testes de neutralização, podem não ser confiáveis por causa da existência de reações cruzadas, havendo dessa forma, uma grande dificuldade na interpretação destes resultados, levando a uma subnotificada na população. Outro fator que pode levar a essa questão é o uso de vacinas, que podem complicar o diagnóstico de infecções naturais.

Métodos de detecção direta consistem principalmente de testes moleculares e inoculação em cultivos celulares ou camundongos neonatos. Porém, a co-circulação dos múltiplos flavivírus no Brasil, seja no ambiente urbano, peri-urbano ou silvestre, que resulta em seres humanos quadros febris indistinguíveis, levam à necessidade de testes diagnósticos rápidos que possam diferenciá-los. Os ensaios mais fidedignos são os testes moleculares e o ELISA NS1, de detecção de fase aguda (WILDER-SMITH et al., 2017). Este último, porém, não está disponível para todos os vírus. Dessa forma, é de suma importância que se busquem testes sensíveis e específicos para esta detecção. Ainda, devido à dificuldade da realização de ensaios sorológicos em amostras de animais reservatórios ou sentinelas, a detecção por meio de RT-qPCR, principalmente nas aves, contribuiria para a maior compreensão de seus papéis no ciclo enzóotico. Essa ferramenta pode ser usada também para vigilâncias entomológicas e acarológicas, podendo levar ainda à descoberta de vírus ainda desconhecidos.

Como mamíferos e aves atuam como principais hospedeiros primários de inúmeros arbovírus, nos quais a infecção varia de assintomática até uma doença fatal hemorrágica ou com manifestação neurológica, é imprescindível que se faça de forma ativa uma pesquisa de agentes virais zoonóticos nessa população, bem como nos vetores, em especial os flavivírus, que são causadores de doenças graves no país e com potencial risco de disseminação para novas áreas sem uma prévia ocorrência. Assim, o uso de RT-qPCR por meio de sonda Taqman, teste molecular 
rápido de alta sensibilidade e especifidade, pode contribuir, tanto para elucidação de diagnósticos diferenciais em seres humanos de quadros causados por flavivírus, como para uma melhora em estudos de vigilância a campo com coleta de vetores e amostras de animais sentinelas ou sintomáticos, ferramentas estas que podem auxiliar em uma resposta rápida a uma emergência em saúde pública, além de contribuir para um panorama real da circulação destes vírus no Brasil. 


\section{REVISÃO DA LITERATURA}

\subsection{FLAVIVIRUS}

O gênero Flavivirus, pertencente à família Flaviviridae, consiste de 53 espécies de vírus transmitidos por artrópodes de acordo com 0 9० ICTV (SIMMONDS et al., 2017). O gênero é dividido em quatro clados: vírus específicos de insetos, que não possuem a capacidade de replicação em vertebrados; vírus de vertebrados que não necessitam de vetor; vírus transmitidos por carrapatos, que se replicam em carrapatos e vertebrados; e vírus transmitidos por mosquitos, que se replicam em mosquitos e vertebrados (GAUNT et al., 2001; KUNO; CHANG, 2005). Aqueles transmitidos por carrapatos são divididos em flavivirus patogênicos associados primariamente com lxodes spp. e roedores, e não patogênicos, associados a carrapatos Ornithodorus spp., que parasitam primariamente aves marinhas (GRARD et al., 2007). Não há descrição de sua ocorrência no Brasil. Os vírus transmitidos por mosquitos são, por sua vez, subdivididos entre os que são associados a mosquitos do gênero Culex spp., que são preferencialmente ornitofílicos, e associados aos Aedes spp., cuja alimentação se dá principalmente em mamíferos (GAUNT et al., 2001). Vírus não associados a vetores são divididos a partir de sua associação com roedores ou morcegos (GAUNT et al., 2001). Curiosamente, a árvore filogenética derivada da NS5 tem como grupo basal este último, o que sugere que uma transmissão direta precedeu a biológica (KUNO et al., 1998a). O gênero inclui ainda 2 linhagens divergentes não associadas ainda com nenhum grupo reconhecido pelo ICTV (SIMMONDS et al., 2017): Tamana bat virus, isolado de um morcego frugívoro em 1973, em Trinidad e Tobago (GRARD et al., 2007) e Ngoye virus, identificado por meio de biologia molecular em carrapatos do gênero Rhipicephalus no Senegal (GRARD et al., 2006).

\subsection{GENOMA E REPLICAÇÃO}


Os vírions deste gênero são tipicamente esféricos com um envelope proteico, com genoma composto por uma fita única de RNA não segmentado de senso positivo, tendo aproximadamente entre 9.2 a $11 \mathrm{~kb}$ (SIMMONDS et al., 2017). Este genoma possui uma única sequência aberta de leitura (ORF) com 10.233 nucleotídeos que codificam inúmeras proteínas, flanqueada por duas regiões não codificantes (UTR) 5' 3', com cerca de 100 nucleotídeos e 400 a 700 nucleotídeos, respectivamente (LINDENBACH et al., 2007). Vírions envelopados são compostos por uma camada bilipídica com uma ou mais espécies de glicoproteínas do envelope (E), que envolve o nucleocapsídeo, que consiste de uma fita única de RNA com senso positivo complexado com cópias múltiplas da proteína do capsídeo (C) (LINDENBACH et al., 2007). O baixo pH da via endossomal induz a fusão do envelope com membranas celulares. $O$ genoma viral tem as seguintes funções no ciclo: como RNA mensageiro, para tradução das proteínas; como molde durante a replicação e montagem de novas partículas virais (LINDENBACH et al., 2007). A poliproteína produz três proteínas estruturais: capsídeo (C), envelope (E) e membrana (M), e sete não estruturais: NS1, NS2A, NS2B, NS3, NS4A, NS4B e NS5 (HEINZ; ALLISON, 2000) que desempenham funções reguladoras e de expressão do vírus, como a replicação, virulência e patogenicidade (LINDENBACH et al., 2007). 
Figura 1 - Organização do genoma e da poliproteína dos membros do gênero Flavivirus, indicando as proteínas estruturais e não estruturais geradas após processo proteolítico.

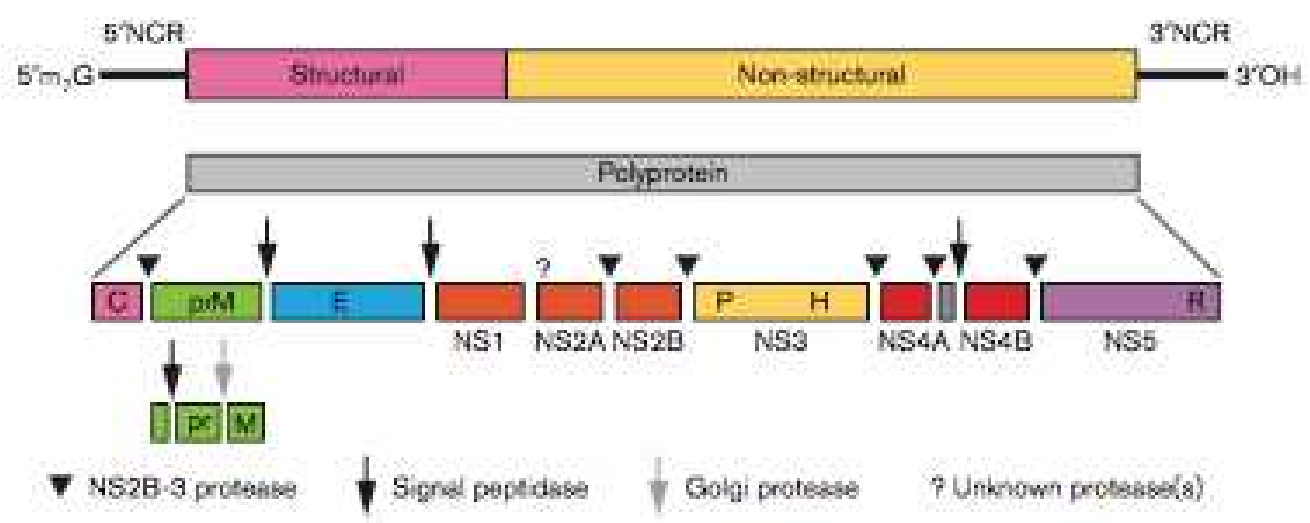

Fonte: ICTV Virus Taxonomy Profile: Flaviviridae , 2017.

As proteínas virais são sintetizadas como parte da poliproteína, que é clivada por proteases celulares e virais. As proteínas estruturais $\mathrm{C}, \mathrm{E}$ e $\mathrm{M}$ estão contidas na porção $\mathrm{N}$-proximal da poliproteína, enquanto que as não estruturais estão no restante da mesma (Figura 1) (LINDENBACH et al., 2007). O ciclo replicativo destes vírus inicia-se mediante a ligação do receptor à superfície celular. Não se conhece ainda qual a estrutura que serve como receptor, porém diversas moléculas presentes na superfície celular têm se mostrado capazes de interagir com partículas de flavivírus (LINDENBACH et al., 2007). Após a adsorção, a partícula é endocitada em vesículas recobertas por clatrinas. O baixo pH do endossoma induz a fusão do envelope do vírus com membranas celulares, provocando mudanças conformacionais da proteína $\mathrm{E}$, para, então, liberar o nucleocapsídeo no citoplasma (LINDENBACH et al., 2007). Após a perda do capsídeo, o genoma de RNA é liberado para o citoplasma (LINDENBACH et al., 2007). As proteínas estruturais são codificadas na porção Nterminal da poliproteína, e as proteínas não estruturais na parte restante (LINDENBACH et al., 2007).

Os flavivírus replicam-se no citoplasma, associados às membranas, por meio de interações que envolvem as pequenas proteínas hidrofóbicas NS, o RNA viral, e, presumivelmente, alguns fatores do hospedeiro (LINDENBACH et al., 2007). A síntese de uma fita de RNA de polaridade negativa é a primeira etapa da replicação do RNA genômico, que por sua vez servirá de molde para novas fitas de RNA de polaridade positiva (LINDENBACH et al., 2007). A finalização do ciclo replicativo ocorre com a montagem das novas partículas virais, próximo ao retículo endoplasmático, 
onde o nucleocapsídeo é envelopado (LINDENBACH et al., 2007). A transição até a membrana plasmática é realizada pelas vesículas que se fundem com a membrana celular e a liberação de novas partículas virais ocorre principalmente por exocitose (LINDENBACH et al., 2007).

\subsection{DINÂMICA VIRAL NA INFECÇÃO DE MOSQUITOS}

Surtos causados pelos flavivírus são influenciados por fatores intrínsecos, como a cepa viral, competência vetorial (proporção de vetores que, após ingestão, tornam-se infectivos) e susceptibilidade do hospedeiro, ou extrínsecos, tais como temperatura, quantidade de chuva e atividades antrópicas, que podem afetar a biologia do mosquito.

A transmissão de um arbovírus a partir de mosquitos competentes se dá somente passado o período extrínseco de incubação (PEI), ou seja, após a aquisicição de partículas virais infectivas no repasto sanguíneo. Os vírus atingem a parte posterior do mesentério, onde se dá a replicação, com posterior disseminação para hemocela e então para os vários tecidos, incluindo as glândulas salivares e transmissão do vírus para um hospedeiro susceptível durante um novo repasto (KRAMER; EBEL, 2003). Esse período de tempo dura de 8 a 14 dias e depende da temperatura ambiente, da cepa viral e do vetor.

Segundo alguns estudos, o período extrínseco de incubação (PEI) diminui com o aumento da temperatura (REISEN et al., 1993). Esta, quando aliada à precipitação, pode afetar ainda a transmissão de arbovírus por causarem impacto na abundância dos vetores (EPSTEIN, 2001; HUBALEK, 2000), seu comportamento alimentar (VAN HANDEL et al., 1994) e a longevidade e duração do ciclo gonadotrófico (FOCKS et al, 1995). Além disso, o aquecimento global pode aumentar a probabilidade de epidemias em países com clima temperado (JETTEN, FOCKS, 1997).

\subsection{DIAGNÓSTICO DIRETO}


Até a década de 1980, a detecção viral consistia basicamente de isolamento em cultivos celulares seguido de imunofluorescência, isolamento viral em camundongos ou microscopia eletrônica (CHAMBERS; MONATH, 2003). O isolamento viral requer partículas viáveis na amostra, podendo levar uma semana ou mais para obtenção do resultado, enquanto que a microscopia eletrônica depende de equipamento específico e de alto custo, bem como pessoal altamente capacitado, sendo ainda inviável para um grande número de amostras (CHAMBERS; MONATH, 2003). Durante os últimos anos, no entanto, foram desenvolvidos vários ensaios de RT-PCR para amplificação molecular dos Flavivírus com uso de primers degenerados, com posterior visualização em gel de agarose (BRONZONI et al., 2005; CHANG et al., 1994; FIGUEIREDO et al., 1998; KUNO, 1998a; SCARAMOZZINO et al., 2001). Posteriormente, com o advento da PCR em tempo real, outros protocolos foram desenvolvidos, tanto pelo método de SYBR Green ou por sonda tipo TaqMan (JOHNSON et al., 2010; MOUREAU et al., 2007; PATEL et al., 2013), com variações nos limites de detecção e nos vírus detectados.

\subsection{FLAVIVÍRUS BRASILEIROS EM ESTUDO}

\subsubsection{Vírus da Febre Amarela (VFA)}

O vírus da febre amarela, causador de uma doença hemorrágica aguda, foi o primeiro Flavivírus descrito, sendo, portanto, o protótipo desta família, isolado em 1927 e cultivado in vitro em 1932. Além disso, foi a primeira doença transmitida por vetor cientificamente comprovada, responsável por grandes epidemias na África e nas Américas no final do século XIX e início do XX (FINLAY, 1937; REED et al., 1901; STRODE, 1951). A doença, na sua forma urbana, é mantida por seres humanos e mosquitos da espécie Aedes aegypti (REED et al., 1901; STRODE, 1951); na forma silvestre, tem seu ciclo enzoótico entre primatas não humanos e mosquitos arbóreos, principalmente Haemagogus spp e Sabethes spp na América do Sul (RODANICHE, GALINDO, 1957a; RODANICHE et al., 1957b; RODANICHE, GALINDO, JOHNSON, 1957; RAWLINS et al., 1990; VASCONCENLOS et al., 2003; 
CARDOSO et al., 2010) e Aedes spp na África (SHANNON et al., 1938; MONATH et al., 1989; BARRETT, MONATH, 2003).

\subsubsection{Histórico}

O primeiro relato de epidemia de uma enfermidade com sintomatologia parecida à da febre amarela no Hemisfério Ocidental é um manuscrito Maia de 1648 existente no México, na península de Yucatán (CARTER, 1931). Durante os séculos XVIII e XIX, surtos foram descritos nas Américas do Sul e Central, bem como regiões portuárias da América do Norte e da Europa (TOMLINSON; HODGSON, 2005).

Durante os séculos XIX e XX, houve inúmeros debates acerca do modo de transmissão da febre amarela. O pesquisador Carlos Finlay, médico cubano, em 1881, foi o primeiro a propor que a mesma era transmitida a partir de mosquitos, e não por miasmas ou de pessoa a pessoa, como se acreditava. Posteriormente, no início do século XX, Walter Reed e colaboradores relataram que o agente era filtrável, transmitido pela picada do mosquito Aedes aegypti. O vírus foi somente isolado em 1927 de um paciente de Gana (Asibi) (STAPLES; MONATH, 2008).

No Brasil, o primeiro relato da presença da mesma data do século XVII, tornando-se a partir daí a principal doença infecciosa do país. Durante o período colonial, o país sofreu diversas epidemias, sendo a primeira em 1685, na cidade de Olinda e em outras de Pernambuco, além de um grande surto na Bahia, em 1686 (TEIXEIRA, 2001).

A epidemia descrita em meados do século XIX na capital brasileira foi atribuída à chegada de um navio negreiro vindo de Nova Orleans, com escalas em Havana e Salvador antes de atracar no Rio de Janeiro, em dezembro de 1849. Segundo estimativas, ocorreram 90.658 casos, com 4.160 mortes (TEIXEIRA, 2001). Foi então constituída a Junta de Higiene Pública, que, em 1886, transformou-se em Inspetoria Geral de Higiene e Inspetoria Geral de Saúde dos Portos (TEIXEIRA, 2001). Outras duas grandes epidemias ocorreram em 1873 e 1876, com 3.659 e 
3.476 óbitos, respectivamente. Elas ocorriam em épocas de calor e chuvas (TEIXEIRA, 2001).

Posteriormente, houve epidemia de febre amarela na cidade de Santos (SP), zona portuária pela qual havia entrada de imigrantes que iriam trabalhar nas lavouras cafeeiras, chegando posteriormente a Campinas, capital agrícola da província e seu segundo maior centro. De lá, os surtos se disseminaram para o Oeste (TEIXEIRA, 2001).

A teoria da transmissão pela picada de um mosquito foi aceita por Emílio Ribas, diretor do Serviço Sanitário e, acompanhado por Adolpho Lutz, empenharamse para prová-la em 1902, utilizando voluntários no Hospital de Isolamento em São Paulo. Ao final, foi provado que a febre amarela não era contagiosa, e que o único vetor de transmissão da doença era o mosquito (TEIXEIRA, 2001). Desde 1901, porém, as comissões sanitárias que atuavam em Sorocaba já realizavam ações que procuravam acabar com as águas estagnadas que pudessem facilitar 0 aparecimento de mosquitos. Em 1902, tal controle foi realizado na cidade de São Simão e, no ano seguinte, o próprio Ribas comandou a destruição dos focos de mosquitos, como medida principal de profilaxia. Todas essas cidades acabaram, em pouco tempo, livres da febre amarela (TEIXEIRA, 2001).

Em 1915, as únicas áreas endêmicas na América eram Guayaquil, no Equador, e os estados da Bahia e Pernambuco, no Brasil (SOPER, 1944), graças a programas de controle de erradicação do mosquito financiados pela Fundação Rockefeller. Em 1928, no entanto, houve uma emergência da doença no Rio de Janeiro, e investigações subsequentes levaram à descrição do ciclo silvestre, envolvendo primatas não humanos, e mosquitos Haemagogus sp. (SOPER et al., 1933; SOPER, 1944). A primeira cepa sul americana, JSS, foi identificada no Brasil em 1935 (MONATH, 2001). A última epidemia urbana ocorreu em Serra Madureira, no Acre, em 1942 (SOPER, 1942).

\subsubsection{Ecologia e Epidemiologia}

Na natureza, o virus é mantido pela transmissao entre primatas não humanos $(\mathrm{PNH})$ e mosquitos hematófagos, especialmente os que pertencem aos gêneros 
Haemagogus, Sabethes chloropterus e Aedes (Stegomyia) na América do Sul e na África, respectivamente, e também por transmissão transovariana nos vetores (BARRETT; MONATH, 2003; MONATH; VASCONCELOS, 2015). Apenas PNHs parecem estar implicados no ciclo de transmissão, apresentando viremia curta com duração de 2 a 5 dias. Esses animais ou morrem graças à infecção, ou adquirem imunidade duradoura, atuando, portanto, como amplificadores da febre amarela (BARRETT; MONATH, 2003). No Brasil, os seres humanos são infectados esporadicamente em um ciclo silvestre do vírus, quando adentram áreas de mata ou mesmo peri-urbanas, e são picados por mosquitos que se alimentaram em PNH virêmico. Porém, podem servir também como hospedeiros em um ciclo de transmissão intra-humana, cujos vetores são os mosquitos Aedes aegypti, conhecida como febre amarela urbana (MONATH; VASCONCELOS, 2015). Se uma fêmea picar um vertebrado infectado que apresente uma viremia acima de $10^{4}$ $\mathrm{PFU} / \mathrm{mL}$, o vírus é transmitido no próximo repasto sanguíneo, passado o $\mathrm{PEI}$ (BARRETT; MONATH, 2003).

$\mathrm{Na}$ África, a epidemia da doença é descrita nas formas silvestre e urbana, ocorrendo dessa forma grandes epidemias (MONATH; VASCONCELOS, 2015). A primeira delas descrita ocorreu em tropas britânicas no Senegal, em 1778 (HADDOW, 1968). Apesar de outros surtos descritos no oeste africano, estes não eram tão severos como aqueles que ocorriam no Novo Mundo, que apresentavam taxas de letalidade maiores. Por outro lado, foram raras as epidemias descritas no leste da África, quando, em 1959, surtos ocorreram na fronteira do Sudão com a Etiópia, causando uma grande epidemia entre 1960 e 1962 (SOPER, 1944; HADDOW, 1968). Surtos menores continuaram a acontecer no oeste e centro africanos até o início do século XXI (ORGANIZAÇÃO MUNDIAL DE SAÚDE, 2000). O principal foco enzoótico é a floresta equatorial, que se estende da Uganda até Angola, em que as epidemias ocorrem em intervalos irregulares de 5 a 20 anos (MONATH, VASCONCELOS, 2015). Há, ainda, a chamada zona de emergência, localizada nas regiões de savana africana, onde mosquitos Aedes sp. alcançam altas densidades populacionais, transferindo o vírus dos PNHs ao homem, e, posteriormente, entre eles. O vírus é mantido durante o período seco através da transmissão vertical nos vetores (MONATH, 2001). Os vetores na África são Aedes africanus, A. furcifer, A. vittatus, A. luteocephalus, A. opok, A. metallicus, A. 
simpsoni, e A. bromeliae no leste africano (BARRETT; HIGGS, 2007; MONATH; VASCONCELOS, 2015).

Na Região Amazônica, assim como em outras regiões endêmicas do país, ocorrem surtos de epizootias a cada 5 a 7 anos (VASCONCELOS, 2003). Essa periodicidade dá-se provavelmente pela renovação de PNHs não imunes ao vírus, pois eles são essenciais para a amplificação deste, o que não ocorre com a população dos vetores. Tais epizootias, especialmente PNHs do gênero Alouatta, são indicadores da ocorrência em casos humanos, por isso constam no rol de doenças de notificação imediata no país. No Brasil, o vetor mais importante atualmente é o mosquito Haemagogus janthinomys (VASCONCELOS et al., 1997), enquanto que $\mathrm{Hg}$. leucocelaenus e Sabethes spp. atuam como vetores secundários (VASCONCELOS et al., 2003). Os mosquitos do gênero Haemagogus são essencialmente diurnos, silvestres e acrodendrófilos, com ovos muito resistentes à dessecação, que são colocados em substratos úmidos de recipientes naturais, especialmente ocos de árvores, com eclosão na época das chuvas. São encontrados quase que exclusivamente em florestas tropicais úmidas primárias e nas suas imediações, e raramente no peridomicílio (CONSOLI, OLIVEIRA, 1994). Por causa dessa característica, a febre amarela ocorre geralmente de dezembro a maio, com pico durante os 3 primeiros meses do ano, quando a população dos vetores está alta (BARRETT; MONATH, 2003). O Haemagogus janthinomys, uma vez infectado, torna-se infectante por toda sua vida, que pode ser de até 3 meses. Nesta espécie é descrita a transmissão vertical. Além disso, as fêmeas têm longa capacidade de vôo, podendo alcançar até $11 \mathrm{~km}$, inclusive entre florestas separadas por cerrados (CONSOLI, OLIVEIRA, 1994).

A partir de 1997, estendendo-se ainda durante os primeiros anos do século XXI, observou-se uma intensa circulação do vírus no Brasil, com início no Pará e em Goiás, que se alastrou mais tarde até o centro-oeste e também a outros países, como Paraguai e Argentina (MONATH; VASCONCELOS, 2015). Outra onda de disseminação do vírus foi observada a partir de 2008. Em 2009, epidemias e epizootias foram descritas, atingindo o sudeste e o sul do Brasil, consideradas até então como áreas livres. No estado de São Paulo, foram reportados 28 casos humanos com 11 óbitos em 2009 (MONATH; VASCONCELOS, 2015), e 99 eventos 
epizoóticos, com 174 animais positivos (MORENO et al., 2011).

No final de 2015, houve uma epidemia em Angola que se alastrou para a República Democrática do Congo, a qual totalizou 7.334 casos suspeitos, 962 casos suspeitos e com 393 óbitos, incluindo a capital Luanda (GROBBELAAR et al., 2016; KRAEMER et al., 2017). Posteriormente, casos importados de trabalhadores provenientes desse continente foram detectados na China, com um caso de óbito, colocando milhões de pessoas em risco na Ásia devido à presença de vetores, área considerada livre da doença (CHEN et al., 2016; CUI et al., 2017).

No Brasil, de dezembro de 2016 até 31 de maio de 2017, de acordo com o Ministério da Saúde (2017c), foram notificados 3.240 casos de febre amarela, dos quais foram confirmados 792 com 435 óbitos, em um total de 9 Estados e 130 municípios, sendo este considerado o maior surto da doença nos últimos anos, envolvendo áreas consideradas antes como livres de vacinação. Não houve, até o momento, nenhum caso urbano de febre amarela no país. Foram notificadas, ainda, durante esse período, 3.850 epizootias, com 642 confirmadas para febre amarela (MINSTÉRIO DA SAÚDE, 2017c). Ainda, no início de 2017, foi detectado um caso importado na Holanda, em uma mulher que viajou para o Suriname, que apresentou febre e sinais de alterações hepáticas (WOUTHUYZEN-BAKKER et al., 2017).

\subsubsection{Manifestações Clínicas}

Apesar da existência de uma vacina eficaz, estima-se que ainda ocorram 200 mil casos da doença no mundo, com 30.000 mortes anualmente, principalmente no continente africano (VAINIO, CUTTS, 1998). O período de incubação após a picada do vetor é de 3 a 6 dias. Durante o chamado período de infecção, nos casos sintomáticos, que dura cerca de 3 dias, há título viral suficiente para infectar mosquitos (GARDNER; RYMAN, 2010). Nos casos mais leves, os sintomas são inespecíficos, e incluem febre e dor de cabeça. Este estágio é geralmente seguido pelo período de remissão, no qual muitos casos evoluem para cura (GARDNER; RYMAN, 2010). Em alguns pacientes, após uma breve remissão dos sintomas, a doença se manifesta de uma forma mais grave (período de intoxicação), com febre alta, epistaxe, icterícia, dor epigástrica, hematêmese, melena e outras 
manifestações hemorrágicas, com evolução para coma e morte. Podem ocorrer, ainda, acometimento renal, com albominúria e insuficiência aguda, e do SNC, manifestado por confusão mental e coma. Nesse estágio, são detectados anticorpos, sendo a viremia ausente (GARDNER; RYMAN, 2010). Estima-se que 55\% das infecções sejam assintomáticas, 33\% sejam de doença leve e que $12 \%$ resultem na forma grave (JOHANSSON; VASCONCELOS; STAPLES, 2014). Na África, a taxa de letalidade para esses casos é de aproximadamente $20 \%$, enquanto que na América do Sul é de cerca de 40 a 60\% (MONATH; VASCONCELOS, 2015).

\subsubsection{Filogenia}

Estudos filogenéticos mostraram que o vírus pode ser dividido em 2 grupos geográficos com diferentes linhagens virais observadas na África e nas Américas, com 7 genótipos principais: cinco africanos (Angola, Leste Africano, Leste/Centro Africano, Oeste/Centro e Oeste Africano II) e Sul Americanos (SA) I e II, sendo que estes últimos são monofiléticos (BECK et al., 2013; BRYANT; BARRETT, 2003; BRYANT; HOLMES; BARRETT, 2007), cuja origem se deu provavelmente no Brasil (AUGUSTE et al., 2010). Tais observações também revelam que os isolados sul americanos são mais relacionados aos do oeste africano, enquanto que os do leste africano são os mais divergentes (BRYANT; HOLMES; BARRETT, 2007). Esse padrão mostra-se compatível com a hipótese do surgimento do vírus no continente africano, mais provavelmente na região leste, e que foi importado para as Américas a partir do oeste africano (BRYANT; HOLMES; BARRETT, 2007). Estes autores mostram ainda que a média estimada de divergência destes clados deu-se há aproximadamente 470 anos, enquanto que a origem dos genótipos sul americanos é de 306 anos, dando suporte a prováveis múltiplas introduções virais feita na época das rotas de escravos.

O Brasil foi, provavelmente, no decorrer dos anos, através da Região Amazônica, a principal fonte de introduções do VFA para alguns países da América Latina como Venezuela, Peru, Trinidad e Tobago, e, provavelmente Equador, onde ocorreram evoluções independentes (AUGUSTE et al., 2010; AUGUSTE et al., 2015). A região Norte, onde supostamente se originou o genótipo SAI, em torno de 
1908, foi também a fonte de disseminação para outros estados brasileiros ao longo da segunda metade do século XX (MIR et al., 2017).

Com exceção de uma amostra do VFA de Rondônia, a qual pertence ao genótipo SA II, junto com amostras do Peru e da Bolívia, todas as amostras circulantes no Brasil pertencem ao SA I (BONALDO et al., 2017; DE SOUZA et al., 2010; VASCONCELOS et al., 2004). As mesmas divergiram em dois clados: um mais antigo, já extinto, e outro que se tornou a linhagem dominante, sendo descritos, atualmente, 5 grupos (1A-1E) (DE SOUZA et al., 2010; VASCONCELOS et al., 2004). A linhagem 1A é representada por isolados de 1972 a 1973 em Goiás e um isolado do Pará feito em 1984. A 1B representa amostras obtidas nos estados do Mato Grosso do Sul, Pará, Rondônia e Maranhão entre 1984 e 1996. A linhagem $1 C$ consiste de isolados da Região Amazônica, Maranhão, Goiás e Minas Gerais, entre 1971 e 1998, enquanto que 1D representa a atividade epizoótica ocorrida entre 1998 e 2001 (VASCONCELOS et al., 2004). Finalmente, a nova linhagem 1E, que emergiu da anterior, foi descrita no sudeste brasileiro durante o surto ocorrido a partir de 2008, quando o vírus atingiu novas áreas fora de sua ocorrência esperada (DE SOUZA et al., 2010). Análises dos isolados sul americanos mostram, ainda, que houve uma evolução independente após sua introdução, e que a maior parte de sua dispersão no continente ocorreu nos últimos 50 anos (NUNES et al., 2012).

\subsubsection{Vacina}

Para obtenção da vacina, a cepa Asibi foi primeiramente passada 53 vezes em primatas não humanos antes da tentativa de atenuação em outros tipos de tecidos. Uma das séries, denominada 17D, foi passada 18 vezes em embriões de camundongos, 58 vezes em embrião de galinha e, por fim, 100 vezes em embrião de galinha sem cérebro e medula espinhal (THEILER; SMITH, 1937a). Na 114 passagem da amostra parental, observou-se que o vírus se tornou menos patogênico tanto para camundongos como primatas não humanos, que apresentaram encefalite com febre transiente ao serem desafiados por via intracerebral ou subcutânea. A passagem de número 176 foi menos letal em camundongos quando comparada à $114^{\text {a }}$ passagem quando inoculada por via intracerebral, sendo portanto selecionada para uso como vacina (THEILER; SMITH, 
1937a;). Uma outra vacina atenuada foi desenvolvida concomitantemente a partir de um isolado do Senegal de 1927, que foi usada entre as décadas de 1940 e 1960 em alguns países africanos, e que foi descontinuada em 1980 (GARDNER; RYMAN, 2010). As vacinas para febre amarela utilizadas nos dias de hoje derivam da 17D original, produzida em 1936, que, apesar de menos imunogênica, se mostrou mais segura que a cepa francesa (STUART, 1953; THEILER; SMITH, 1937a, 1937b), sendo a 17DD produzida no Brasil e 17D-204 em outros países, não havendo entre elas diferenças na segurança ou na imunogenicidade (MONATH; VASCONCELOS, 2015). Atualmente, é recomendada somente uma dose para a maior parte das pessoas, sendo a revacinação indicada para alguns viajantes e trabalhadores de laboratório pelo menos 10 anos após a primeira dose (STAPLES et al., 2015). Pessoas não vacinadas que visitam a África em períodos epidêmicos têm um risco estimado de contrair a doença em 50 casos para cada 100 mil, enquanto que na América do Sul esse risco é de 5 casos para cada 100 mil (STAPLES et al., 2015). Nas áreas endêmicas onde há alta cobertura vacinal, ocorrências de surtos diminuíram drasticamente (MONATH, CETRON, 2002).

Apesar de ser considerada uma vacina segura, casos de doença neurológica associados à mesma foram descritos por muitos anos e, em 2001, foi reconhecida também a forma viscetrópica (VASCONCELOS et al., 2001; ADHIYAMAN; OKE; CEFAI, 2001; TROILLET; LAURENCET, 2001; CHAN et al., 2001; MARTIN, TSAI; CROPP, 2001; WERFEL, POPP, 2001; CENTRO DE CONTROLE DE DOENÇAS E PREVENÇÃO, 2001). Clinicamente, esta assemelha-se à forma grave da febre amarela; tendo ocorrência de 0,4 a cada 100 mil doses (LINDSEY; SCHROEDER; MILLER, 2008). Por outro lado, a forma neurológica pode causar meningoencefalite, tanto pela invasão direta do vírus no sistema nervoso central ou por manifestação autoimune, com ocorrência de 0,8 por 100 mil doses. Os fatores de risco para estes efeitos adversos incluem idade (acima de 60 anos), lúpus sistêmico, timoma e outras desordens auto-imunes (MONATH, 2005).

\subsubsection{Vírus Rocio (VROC)}


Durante o início da década de 1970, houve uma epidemia de casos de encefalite em humanos na região do Vale do Ribeira, no sudeste do estado de São Paulo, sem causa conhecida, que teve início em 1975 e disseminou-se por 20 municípios da região. Estima-se que ocorreram cerca de 1.000 casos de infecção, com 100 mortes aproximadamente e $20 \%$ de sobreviventes ficaram com sequelas neurológicas (COIMBRA et al., 1998; LOPES et al., 1978b; IVERSSON, 1988; IVERSSON et al., 1989). No ano seguinte, conseguiu-se o isolamento da amostra protótipo do vírus Rocio a partir do cerebelo de um caso fatal, de um camundongo sentinela e de uma ave silvestre Zenothrichia capensis (LOPES et al., 1978a). Análises sorológicas foram realizadas em aves, sugerindo a participação das mesmas no ciclo de transmissão da doença (FERREIRA et al., 1994). Lopes e colaboradores (1981) isolaram o vírus de mosquitos Psorophora ferox em um estudo no qual foram coletados 38.896 mosquitos pertencentes a 88 espécies na área epidêmica. Inicialmente, acreditou-se que o vírus fosse relacionado antigenicamente ao vírus llheus, sendo agrupado no complexo do vírus da encefalite japonesa (VEJ) (CHAMBERLAIN, 1980), porém, Kuno e colaboradores (1998a) realizaram um estudo filogenético baseado em um gene parcial da proteína NS5, que revelou uma relação próxima, porém distinta, daquele complexo. Atualmente, o vírus Rocio é considerado um genótipo do llheus e, de acordo com o Ninth Report of the International Committee on Taxonomy of Viruses (ICTV), ambos estão incluídos no grupo do vírus Ntaya (LINDENBACH et al., 2007; KING et al., 2012). Ao longo dos anos, alguns testes sorológicos realizados em diferentes regiões do Brasil revelaram anticorpos neutralizantes para o vírus, evidenciando sua circulação nos estados de São Paulo e Bahia (FIGUEIREDO, 1985; TAVARES-NETO et al., 1986; STRAATMANN et al., 1997).

\subsubsection{Vírus Ilheus (VILH)}

O vírus llheus foi isolado pela primeira vez em 1944 de um pool de mosquitos dos gêneros Ochlerotatus e Psorophora em Ihéus, Bahia (LAEMMERT; HUGHES, 1947), PERTENCENDO HOJE AO COMPLEXO ANTIGÊNICO DO VÍRUS NTAYA DE ACORDO COM O ICTV (KING ET AL., 2012). Sugere-se que seu ciclo seja 
mantido por aves e mosquitos, sendo os últimos sua principal fonte de isolamento nas Américas do Sul e Central (RODANICHE, GALINDO, 1957a; RODANICHE, GALINDO, 1961; TRAVASSOS DA ROSA et al., 1998; TURELL et al., 2005). Foram isoladas duas cepas em sangue de aves das espécies Sporophila caerulescens (papa-capim) e Molothrus bonariensis (chupim) no Parque Ecológico do Tietê, no município de São Paulo, detectando-se também anticorpos em aves das espécies Columbina talpacoti, Geopelia cuneata, Molothrus bonariensis e Sicalis flaveola, em saguis das espécies Callithrix jacchus e Callithrix penicillata e no quati Nasua nasua, o que mostra a circulação viral em ambientes urbanos utilizados como área de lazer (PEREIRA et al., 2001). Turell e colaboradores (2005), em coletas que totalizaram a captura de 539.694 mosquitos na Amazônia peruana, que duraram 5 anos, isolaram este vírus de Psophora ferox, um artrópode ávido e diurno. Os mesmos autores, em um estudo separado (dados não publicados), relataram seu isolamento em Culex coronator.

O vírus não é associado a epidemias, sendo detectado esporadicamente em humanos, somente nas Américas Central e do Sul (SRIHONGSE et al., 1967; FIGUEIREDO, 2000; NASSAR et al., 1997; PRIAS-LANDINEZ; BERNAL-CUBIDES, C.; MORALES-ALARCON, 1968), com variações de casos assintomáticos até sinais de envolvimento de sistema nervoso central, sugestivo de encefalite. No Brasil, Nassar e colaboradores (1997) isolaram o vírus em 5 humanos no Estado de São Paulo, todos homens entre 20 e 72 anos, tendo como locais prováveis de infecção o estado de Rondônia, regiões de caverna dos estados do Paraná e Goiás e a floresta Amazônica. Os sintomas mais comuns descritos foram febre, acompanhada de dor de cabeça, mialgia, artralgia e fotofobia. Relataram-se também pacientes com sintomas de pneumonia, diarreia, dores abdominais, exantema e dor retroorbital. Um deles, um homem de 20 anos, teve alterações em sistema nervosa central, apresentando confusão mental e paralisia facial (NASSAR et al., 1997).

O vírus foi ainda isolado no Equador, em 2004, em um soldado apresentando febre, rash cutâneo, epistase, mialgia, dor retroocular, náusea, vômito, icterícia, dor de garganta e dor abdominal com 4 dias de duração. Sequências obtidas nesse estudo mostraram identidades dos genes codificadores de proteínas de envelope e não estrutural 5 (NSP5) variando de 95 a 100\% com os demais isolados (JOHNSON 
et al., 2007). Em 2005, na Bolívia, foi identificado em um garoto que procurou atendimento médico apresentando mal estar, astenia, conjuntivite, rash maculopapular, edema facial, artralgia, mialgia, dor abdominal e cefaleia por 5 dias. Não ocorreu alteração nervosa. Houve detecção de anticorpos IgM monotípicos para o vírus llheus, que foi confirmado por detecção molecular (VENEGAS et al., 2012).

Estudos de soroprevalência foram realizados em equinos do Pantanal, com aumento da soropositividade nos anos estudados (IVERSSON et al., 1993; PAUVOLID-CORREA et al., 2010). No entanto, pouco se sabe sobre a infecção nos animais domésticos. Mais recentemente, isolou-se o vírus de pool de mosquitos Aedes scapularis, também na região do Pantanal, cujo sequenciamento demonstrou 95\% de similaridade com a amostra padrão de 1944, com 44 alterações não sinônimas em aminoácidos e três inserções nucleotídicas na região do Capsídeo (PAUVOLID-CORREA et al., 2013). Análises filogenéticas de NS5 e Envelope agruparam este vírus com $\mathrm{O}$ isolado humano do Equador. $\mathrm{O}$ comportamento antropofílico deste vetor sugere um risco de transmissão de arbovírus aos seres humanos na região (PAUVOLID-CORREA et al., 2013).

\subsubsection{Vírus da Encefalite de Saint Louis (VESL)}

\subsubsection{Histórico e Epidemiologia}

Em 1933, em Saint Louis, Missouri, nos EUA, ocorreu uma epidemia de encefalite na qual foram descritos mais de mil casos, chamada à época de encefalite letárgica (LUMSDEN, 1958). O vírus da encefalite de Saint Louis, pertencente ao complexo do vírus da encefalite japonesa, foi posteriormente isolado a partir de amostras de suspensão de tecido nervoso de óbitos humanos por inoculação intracerebral em macacos rhesus e camundongos (MUCKENFUSS; ARMSTRONG; WEBSTE; 1934; WEBSTER, FITE, 1933). Cerca de 10.000 casos foram descritos durante o ano de 1933, com mais de mil mortes e milhares de infecções leves ou assintomáticas (MONATH, 1980). Grandes surtos foram descritos nos EUA no Missouri (1937), Texas (1954, 1956, 1964, 1966), Mississipi, Ohio, Indiana e Illinois 
em 1975, e na Flórida em 1977 e 1990. A maior parte deles foi descrita tendo uma associação estatística a temperaturas mais elevadas durante a primavera e chuvas abaixo da média no verão (MONATH, 1980).

O ciclo silvestre deste vírus provavelmente já ocorria no Novo Mundo há milhares de anos, mas a chegada dos europeus no século XVII trouxe alterações antrópicas ao ambiente, que levou a um aumento de mosquitos do gênero Culex e de algumas aves reservatórios, intensificando-se, dessa forma, o contato homemmosquito e a prevalência da infecção. Atualmente, o vírus tem distribuição do Canadá até a Argentina (MONATH, 1980), com ampla distribuição na América do Norte, cujo ciclo de transmissão envolve mosquitos do gênero Culex como vetores e pássaros selvagens peridomésticos como hospedeiros amplificadores (REISEN, 2003).

Mesmo que diversos estudos de soroprevalência em animais tenham demonstrado presença de anticorpos anti-VESL em diversas espécies, inoculações experimentais não foram capazes de produzir altas viremias em animais domésticos, incluindo equinos, porcos, bovinos e felinos (MCLEAN, BOWEN, 1980). No entanto, aves de criação de até 1 mês (incluindo frangos e patos) frequentemente desenvolvem viremia suficientemente capaz de infectar mosquitos (HARDY, REEVES, 1990; MCLEAN, BOWEN, 1980), porém, semelhante a adultos, não adoecem. Os que possuem mais de 22 semanas não apresentam viremia detectável, desenvolvendo, no entanto, anticorpos neutralizantes detectáveis nos exames sorológicos de ELISA e HI (MCLEAN, BOWEN, 1980; REISEN et al., 1994). O mesmo ocorre em aves silvestres, com aves jovens apresentando altas viremias. Além disso, nesses animais, esta depende da espécie da cepa viral, tendo duração de até 5 dias após a infecção (MCLEAN, BOWEN, 1980).

Nos Estados Unidos, os vetores são Culex tarsalis, no oeste americano, e Culex pipiens, nas regiões de Ohio e no Mississipi (MCLEAN, BOWEN, 1980). O primeiro desenvolve-se principalmente em áreas de irrigação e, portanto, a maioria dos casos ocorre em zonas rurais. Os principais reservatórios descritos são os passeriformes Carpodacus mexicanus, Agelaius tricolor, Euphagus cyanocephalus e Passer domesticus, e também Zenaidura macroura (rola-carpideira) da ordem 
Columbiforme (MCLEAN, BOWEN, 1980). Mosquitos do complexo Culex pipiens (Culex pipiens pipiens e Culex pipiens quinquefasciatus) ocorrem predominantemente em ambientes urbanos com presença de água poluída. Nestas áreas, aves peridomésticas como corvos, pombas e outras espécies associadas participam no ciclo de transmissão viral (MCLEAN, BOWEN, 1980). Na Flórida, além das aves, guaxinins e roedores, tendo como vetor Culex nigripalpus, que se desenvolve em água fresca dos pântanos, atuam no ciclo rural (MCLEAN, SCOTT, 1979).

O vírus foi também isolado de várias espécies de morcegos, como Tadarida e Myotis, e muitas populações estudadas apresentaram altos níveis de anticorpos neutralizantes (MCLEAN, BOWEN, 1980). Devido às suas hibernações, podem produzir uma infecção duradoura que recidiva natural ou artificialmente (SULKIN; MIURA; TOYOKA, 1970), podendo ter importante papel na manutenção do vírus durante o inverno. No entanto, estudos demonstram que mosquitos do gênero Culex alimentam-se frequentemente em aves, ocasionalmente em grandes mamíferos e lagomorfos, raramente em roedores e quase nunca em morcegos (EDMAN, 1974; REISEN, REEVES, 1990; TEMPELIS, 1975). Pouco se sabe, no entanto, acerca do ciclo de transmissão nas Américas Central e do Sul. O vírus já foi isolado de Culex spp. na região amazônica do Peru (provavelmente de $C x$. coronator), e também de garças e cormorões (SPENCE, 1980). Curiosamente, muitos destes vetores tropicais alimentam-se frequentemente em mamíferos, por isso, acredita-se que haja diferenças significativas entre a ecologia e a epidemiologia do vírus na parte tropical da América.

No Brasil, poucos estudos relatam quais são os vetores e os reservatórios responsáveis pela manutenção do ciclo, tanto em áreas rurais como urbanas. $\mathrm{O}$ primeiro isolamento do vírus foi realizado na região Norte, a partir de pool de mosquitos da espécie Sabethes belisarioi (CAUSEY; SHOPE, THEILER, 1964). Na região amazônica, os reservatórios descritos são pássaros selvagens, primatas, tatus e marsupiais, com Culex declarator e Culex coronator como vetores (VASCONCELOS et al., 1998). Até o fim do século XX, houve somente dois isolamentos de amostras de sangue humano, ambos na região amazônica na década de 70 (LOPES et al., 1979; TSAI, MITCHELL, 1988). Diferentemente dos 
quadros de encefalite observados na América do Norte, a sintomatologia descrita nesses casos foi de febre com icterícia, sem sinais de acometimento do sistema nervoso central (LOPES et al., 1979; TSAI, MITCHELL, 1989). No Estado de São Paulo, inquéritos sorológicos demonstraram a circulação viral em habitantes do Vale do Ribeira, SP (IVERSSON et al. 1981; IVERSSON, 1980), bem como em diversas espécies de aves (FERREIRA et al 1994). Ademais, foi isolado de roedores e de animais sentinelas (LOPES et al., 1979). O vírus foi isolado em humano pela primeira vez neste estado em 2004 a partir de uma mulher com quadro clínico semelhante ao da dengue, por meio de inoculação de amostra de soro em células C6/36 e em camundongos neonatos, sendo posteriormente confirmado com RTPCR e sequenciamento (ROCCO el al., 2005). Recentemente, o material genético do vírus foi detectado em quatro pacientes com sintomas de dengue grave e dois com suspeita de meningoencefalite em São José do Rio Preto (MONDINI et al, 2007a; MONDINI et al., 2007b). Heinen e colaboradores (2015) identificaram em uma área metropolitana de Cuiabá o RNA viral de um pool de fêmeas de $C x$. quinquefaciatus, com uma MIR (taxa mínima de infecção) de 0.29 por 1.000 espécimes. Valores acima de 1 por mil são considerados como tendo impacto para a saúde pública (DAY, 2001). Detectou-se, também, na mesma área, RNA viral em 3 pacientes co-infectados com DENV-4, sendo um deles com tripla infecção com DENV-1. Nenhum dos pacientes relatou viagem a áreas rurais, indicando que a transmissão tenha ocorrido em área urbana (HEINEN et al., 2015).

Por outro lado, inúmeros são os estudos de soroprevalência em cavalos no Pantanal e na Amazônia (RODRIGUES et al., 2010; PAUVOLID-CORREA et al., 2010), e em primatas e cavalos no Paraná (SVOBODA et al., 2014) revelando a circulação viral em diversas regiões do país. Recentemente, teve seu isolamento confirmado de um equino com sinais de encefalite, em Minas Gerais (ROSA et al., 2013). O baixo número de isolados em regiões tropicais reflete um diagnóstico inadequado, principalmente pela sintomatologia semelhante com dengue, circulação de cepas menos virulentas e/ou ciclos enzóoticos envolvendo mosquitos não antropofílicos (SPENCE et al., 1980).

\subsubsection{Doença}


O número de casos da forma neuroinvasiva da doença flutua ao longo dos anos, sendo relatados, de 1964 a 2010, mais de 4.000 casos (CENTRO DE CONTROLE DE DOENÇAS E PREVENÇÃO, 2016). A maior parte das infeções, especialmente em jovens e adultos, é assintomática. Indivíduos sintomáticos apresentam uma doença branda de curta duração e cura espontânea (TSAI, MITCHELL, 1989), com quadros mais graves em idosos. A infecção por este vírus pode ser dividida em três síndromes: encefalite, incluindo meningoencefalite e encefalomielite, com febre alta, alteração de consciência e disfunção neurológica; meningite asséptica, com febre alta e enrijecimento de pescoço, e por fim, quadro febril com cefaleia, possivelmente associado com náuseas e vômitos, sem acometimento do SNC (BRINKER, MONATH, 1980).

\subsubsection{Filogenia}

Análises filogenéticas avaliando-se 62 isolados de diversas localidades de sua ocorrência classificaram-no em 7 linhagens, revelando que algumas delas permaneceram inalteradas por períodos maior que 25 anos (KRAMER; CHANDLER, 2001). Porém, uma análise filogenética mais recente realizada utilizando-se também isolados de diferentes estados da Amazônia brasileira por Rodrigues e colaboradores (2010) revelou a existência de oito grupos filogenéticos (I-VIII), sendo os grupos de I a VII correspondentes ao que foi previamente descrito. Quatorze delas foram classificadas como genótipo VIII (VIIIA e VIIIB), 23 como genótipo V (VA e VB) e 7 como VIIIA. Ademais, o vírus da Encefalite de Saint Louis isolado no estado de São Paulo (ROCCO et al., 2005) foi identificado como genótipo III (RODRIGUES et al., 2010; SANTOS et al., 2006), a qual foi geneticamente relacionada com amostras isoladas de Culex quinquefasciatus durante um surto ocorrido em Córdoba, na Argentina (DIAZ et al., 2006), enquanto que um isolado feito por Rosa e colaboradores em Minas Gerias (2013) foi identificado como genótipo VB. As amostras obtidas em São Paulo são, portanto, distintas daquelas encontradas na Amazônica, e provavelmente restritas à Mata Atlântica.

Estima-se que o tempo de emergência do ancestral comum mais recente para o vírus nas Américas tenha ocorrido entre 1875 e 1973, enquanto que para o genótipo II, o primeiro a emergir na América, calcula-se que tenha havido um 
ancestral comum que emergiu entre 1893 e 1942 (RODRIGUES et al., 2010). Dessa forma, parece que o VESL seja um flavivírus relativamente novo, quando comparado a outros de mesmo gênero. Esta análise também indica a disseminação do vírus da América do Sul para a do Norte, com eventos evolutivos ocorrendo simultaneamente em ambos os hemisférios, gerando dessa forma uma emergência e dispersão geográfica de linhagens distintas ao longo do tempo, feita provavelmente por aves migratórias (RODRIGUES et al., 2010).

\subsubsection{Vírus Zika (VZIK)}

\subsubsection{Epidemiologia e Histórico}

O vírus Zika é um flavivirus emergente (KUNO et al., 1998a), que foi isolado primeiramente em 1947 a partir de um macaco rhesus, em Uganda (SIMPSON, 1964). É um membro do complexo Spondweni, cujo ciclo de transmissão se dá por mosquitos do gênero Aedes e primatas não humanos (HAYES, 2009). Até o início do século XXI, somente 14 casos da doença haviam sido descritos na África e na Ásia, porém sem nenhum surto relatado (FAGBAMI, 1979; PELLISIER, 1954; OLSON et al., 1981). O primeiro grande surto foi na Micronésia, na ilha Yap, onde foram detectados casos de pacientes com exantema, conjuntivite, febre moderada, artralgia e artrite (DUFFY et al., 2009). Lá, apesar de sorologias IgM positivas para dengue, o vírus Zika foi confirmado como agente etiológico causador deste. (LANCIOTTI et al., 2008). Estima-se que 73\% da população acima de 3 anos tenha se infectado na região, com altas taxas de ataque (DUFFY et al., 2009), com o Aedes hensilli implicado como vetor (LEDERMANN et al., 2014).

A partir daí, o vírus começou a se alastrar, causando surtos na Polinésia Francesa, em 2013 (CAO-LORMEAU, 2014), Nova Caledônia, Ilhas Cook e Ilha da Páscoa (MUSSO; NILLES; CAO-LORMEAU, 2014). O primeiro caso autóctone no Brasil foi detectado no início de 2015 (ZANLUCA et al., 2015). Na mesma época, o vírus foi isolado pela primeira vez no país no Estado de São Paulo a partir de uma amostra de um doador de sangue sintomático e de seu receptor, assintomático. A 
análise do genoma completo revelou que o vírus Zika pertencia à linhagem asiática, a mesma responsável pelos surtos anteriores descritos (CUNHA et al., 2016). Análises filogenéticas e de relógio molecular utilizando outros isolados do país confirmaram a linhagem asiática circulante, e estimando que a entrada do vírus na América tenha ocorrido entre maio e dezembro de 2013 a partir de viajantes virêmicos, provavelmente durante a Copa das Confederações, sediada no Brasil, e com uma única introdução (FARIA et al., 2016). Concomitantemente ao isolado de São Paulo, ocorreram relatos de doença exantemática no nordeste brasileiro com posterior confirmação do vírus Zika como agente causal, sendo descrito o primeiro surto no estado de Pernambuco, com 895 infecções classificadas por critério clínico epidemiológico (BRITO et al., 2016), e na Bahia (CARDOSO et al., 2015). Posteriormente, o vírus disseminou-se para outros países da América, incluindo os Estados Unidos da América, com casos autóctones relatados (LIKOS et al., 2016; THOMAS et al., 2016; OPAS, 2017).

Entre 2016 e 2017, até a semana epidemiológica 35, foram registrados 231.793 casos prováveis de febre pelo vírus Zika no país, com 8 óbitos confirmados laboratorialmente, sendo quatro no Rio de Janeiro, dois no Espírito Santo, um no Maranhão e um na Paraíba, com as regiões CentroOeste e Norte apresentando as maiores taxas de incidência da doença. Em relação às gestantes, foram registrados 2.105 casos prováveis, sendo 728 confirmados por critério clínico-epidemiológico ou laboratorial (MINISTÉRIO DA SAÚDE, 2017b). Além disso, até setembro de 2017, as áreas de risco mundiais incluem diversos países africanos, áreas do sudeste asiático, como Paquistão, Indonésia e Índia, Filipinas e Indonésia, toda a América Latina e Caribe, com exceção do Chile, e alguns estados americanos (ORGANIZAÇÃO PAN-AMERICANA DE SAÚDE, 2017). Na Flórida, o surto de 2016 confirmou 256 infecções por vírus Zika, provavelmente a partir de pelo menos quatro introduções distintas de regiões do Caribe (METSKY et al., 2017).

\subsubsection{Manifestações adversas}

Alguns meses após os primeiros relatos da ocorrência do vírus no território brasileiro, houve um aumento de notificação de casos de neonatos ao Ministério da Saúde, apresentando microcefalia nos estados de Pernambuco, Paraíba e Rio Grande do Norte (OLIVEIRA et al., 2016; SCHULER-FACCINI et al., 2016), pertencentes à Região Nordeste do país. 
Posteriormente, RNA viral foi encontrado em líquido amniótico de duas gestantes da Paraíba com histórico de doença exantemática e com diagnóstico de fetos apresentando microcefalia na ultrassonografia (CALVET et al., 2016). Em seguida, detectou-se material genético para vírus Zika em amostras de córtex cerebral, medula oblongata, liquor e em líquido amniótico a partir de um natimorto apresentando microcefalia, hidrencefalia e calcificações intracranianas (SARNO et al., 2016). O RNA viral foi também detectado na Eslovênia, a partir de amostra de tecido nervoso de um feto abortado com microcefalia de uma gestante que residia em Natal, que apresentou sintomas compatíveis com infecção por vírus Zika no primeiro trimestre da gestação (MLAKAR et al., 2016). Os autores sugerem que a ausência de material genético deste vírus em outros tecidos fetais que não o cérebro ocorra graças a um forte neurotropismo (MLAKAR et al., 2016). Driggers e colaboradores (2016) relataram uma gestante com viremia de até 10 semanas após o início dos sintomas, com feto apresentando alterações de sistema nervoso central. Esses autores conseguiram detectar cargas virais altas no cérebro do feto, na placenta, membranas fetais e cordão umbilical, e baixas cargas no músculo, fígado, pulmão e baço, bem como líquido amniótico no momento da interrupção da gestação. O soro da mãe apresentou, neste momento, carga de $2,1 \times 10^{3}$ cópias $/ \mathrm{mL}$ (DRIGGERS et al., 2016). Foram descritas, ainda, alterações oftalmológicas em crianças nascidas com microcefalia com suspeita de infecção congênita pelo vírus Zika (DE PAULA FREITAS et al., 2016). Entre novembro de 2015 até julho de 2017, foram notificados 14.258 casos suspeitos de alterações no crescimento e desenvolvimento possivelmente relacionadas à infecção pelo vírus Zika, dos quais $2.869(20,1 \%)$ foram confirmados e $170(1,2 \%)$ foram classificados como prováveis para relação com infecção congênita durante a gestação (MINISTÉRIO DA SAÚDE, 2017a).

Além dos casos de microcefalia, outra manifestação grave associada ao vírus Zika é a Síndrome de Guillain-Barré (SGB), uma neuropatia autoimune, que tem início geralmente de 2 a 8 semanas após uma infecção viral ou bacteriana, que foi associada ao vírus Zika pela primeira vez durante o surto da Polinésia Francesa, em 2013 (CAO-LORMEAU et al., 2014), com 42 casos confirmados e risco estimado de 2,4 para 10 mil infecções por Zika (MUSSO; NILLES; CAO-LORMEAU, 2014; OEHLER et al., 2014). Até este momento, não havia relatos de formas graves 
causadas pelo vírus. A SGB foi relatada posteriormente em várias regiões afetadas (KASSAVETIS et al., 2016), inclusive no Brasil (BRASIL et al., 2016).

Devido à grande frequência de cruzamento com outros flavivírus em testes sorológicos, o diagnóstico do vírus baseia-se na detecção de RNA viral em amostras de sangue ou soro até o quinto dia após início de sintomas, graças à curta viremia na maioria das pessoas. Como a virúria pode ser maior e mais prolongada que a viremia, amostras de urina até o oitavo dia têm sido utilizadas como alternativa quando o material genético não está mais presente no soro (GOURINAT et al., 2015; HAYES, 2009; HEANG et al., 2012; KUTSUNA et al., 2014). No entanto, foi demonstrada a presença de RNA viral após 26 dias de início dos sintomas na urina, e 58 dias no sangue em um estudo realizado em Israel (LUSTIG et al., 2016). O vírus pode ser também encontrado no sêmen, com relatos de disseminação pela via sexual (FOY et al., 2011; MUSSO et al., 2015a), leite materno (DUPONTROUZEYROL et al., 2016) e saliva (MUSSO et al., 2015b). O vírus foi também isolado no Brasil a partir de urina e saliva em pacientes na fase aguda da doença (BONALDO et al., 2016).

\subsubsection{Filogenia}

Faye e colaboradores (2014) relataram que o vírus provavelmente emergiu em Uganda, provavelmente em 1940 (entre 1892 e 1943), com duas introduções independentes no oeste africano a partir da região leste, sendo a primeira um cluster descrito no Senegal e Costa do Marfim, e uma segunda introdução relacionada com um cluster nigeriano. Uma linhagem adicional de Uganda provavelmente disseminou-se para a Malásia nos anos 40, alcançando a Micronesia nos anos 60, formando a linhagem asiática (HADDOW et al., 2012).

Atualmente, são descritas 3 linhagens virais, baseadas em estudo de filogenia com as proteínas E e NS5: linhagens Africana 1 e 2, e Asiática/Americana (SHEN et al., 2016). A linhagem Africana 1 foi responsável por casos identificados entre 1947 e 1997 e entre 2002 e 2007, enquanto que a linhagem 2 foi identificada em mosquitos isolados do Senegal entre 1998 e 2001 (SHEN et al., 2016). Aparentemente, a linhagem 2 evoluiu separadamente, divergindo anteriormente das 
demais linhagens. Tais resultados indicam que é possível que a circulação de linhagens mais antigas ainda ocorra no Senegal e na Costa do Marfim (SHEN et al., 2016). Como a linhagem 1 também é descrita no primeiro país, provavelmente diferentes recombinações ocorreram entre diferentes genótipos. Os autores descrevem 3 eventos de recombinação, todos em mosquitos, identificados na NS5 nas posições 9652, 9754, 10314, e 10315 (SHEN et al., 2016). Previamente, Faye e colaboradores (2014) identificaram 13 eventos recombinantes utilizando genomas completos do vírus nas posições 1044 a 1095, 5181 a 5238, 9007 a 9132 e 9580 a 9631, também em isolados de mosquitos africanos, mostrando dessa forma a importância de isolados a partir de vetores naturalmente infectados.

Nas Américas, por outro lado, todos os isolados formam um único cluster, com três principais linhagens observadas (ALDUNATE et al., 2017). Os autores relatam ainda a co-circulação de diferentes linhagens genéticas dentro das cidades, como o Rio de Janeiro, revelando portanto um aumento da diversidade viral no continente (ALDUNATE et al., 2017).

\subsubsection{Vírus Bussuquara (VBSQ)}

$O$ vírus Bussuquara foi originalmente isolado do sangue de um primata Alouatta beelzebul sentinela, em Belém, que mais tarde foi a óbito e apresentou sinais semelhantes a febre amarela (GOMES, CAUSEY, 1959). Tem distribuição pelo Caribe e nas Américas Central e do Sul, até a Argentina, porém, foi relatado somente um caso de infecção em seres humanos, no Panamá, em 1971, que apresentou febre, cefaleia e artralgia, com sintomas durando 4 dias (SRIHONGSE, JOHNSON, 1971). Diversos estudos conduzidos em florestas próximas a Belém implicaram o rato-do-espinho (família Echimyidae) como reservatório do vírus, uma vez que esta espécie mostrou ser infectada durante a estação chuvosa por meio de soroconversão em IH (SHOPE, 2003). O vírus foi isolado desta espécie e também em mosquitos do gênero Culex (SHOPE, 2003). 


\subsubsection{Vírus Cacipacore (VCPC)}

O vírus Cacipacore foi primeiramente isolado em 1977 a partir de sangue de Percnostola rufifrons na região Amazônica brasileira, próximo ao Rio Cacipacoré, no Pará (ROSA et al., 1998). Somente um caso humano foi descrito até o presente, ocorrido em 2011, em um paciente de 33 anos residente em área rural de Rondônia, apresentando doença febril com suspeita inicial de dengue, febre amarela ou leptospirose (BATISTA et al., 2011). Ainda não se sabe o vetor implicado em sua transmissão, no entanto, o vírus teve sua detecção molecular em pools de Aedes aegypti, Anopheles sp. e Culex sp. coletados entre 2002 e 2006 na região Amazônica (FIGUEIREDO et al., 2017), sendo também isolado de carrapato Amblyomma sculptum coletado de uma capivara em Matão, SP, em 1997, cujo sequenciamento de genoma completo revelou $99 \%$ de identidade com o protótipo isolado de 1977 (DE FIGUEIREDO ET AL., 2017). Existem, ainda, detecções sorológicas deste agente, assim como outros flavivírus do complexo da encefalite japonesa em búfalos no Pará (CASSEB et al., 2014), equinos no Pantanal (PAUVOLID-CORREA et al., 2010) e primatas não humanos com resposta monotípica no Mato Grosso do Sul (BATISTA et a., 2013).

\subsubsection{Vírus Iguape (VIGP)}

O vírus lguape foi isolado no município homônimo de um camundongo sentinela em 1979 na região do Vale do Ribeira, localizado no estado de São Paulo, após a epidemia de Rocio, porém, não se conhece seu vetor (COIMBRA et al., 1993). Ferreira e colaboradores (1994) mostraram a presença de anticorpos neutralizantes monotípicos para 0 vírus lguape em 25 espécies de aves pertencentes a 16 famílias no Vale do Ribeira, sugerindo o provável papel destes animais no ciclo de manutenção do vírus. Pertence ao grupo do vírus Aroa, junto com o vírus Bussuquara, sendo que este último forma um grupo irmão com o vírus Naranjal, enquanto que o Iguape forma outro com o vírus Aroa (MOUREAU et al., 2015). 
Outros estudos utilizando soros humanos e de animais submetidos a testes de $\mathrm{IH}$ demonstraram anticorpos monotípicos para vírus Iguape, evidenciando a circulação do agente em pássaros, roedores silvestres, marsupiais, morcegos, aves domésticas e humanos (Coimbra et al., 1993). Pouco se sabe, no entanto, acerca de suas manifestações, tanto em humanos como em animais. Dessa forma, considerando a diversidade viral no país, bem como uma possível entrada de novos patógenos e sua provável disseminação e colonização de novas áreas, é importante que se faça, aliado à vigilância passiva dos casos humanos, programas de monitoramento que realizem busca ativa em hospedeiros e vetores, implementando assim as ações de saúde pública no país no que tange a questão dos flavivírus. Ademais, a busca ativa em artrópodes pode levar também à descoberta de novos vírus específicos a eles. O diagnóstico clínico das infecções por esses vírus é difícil por causa da inespecificidade dos sintomas apresentados. Os principais métodos diretos utilizados atualmente no Brasil são a inoculação intracerebral em camundongos neonatos, inoculação em culturas de células e RT-PCR. Além disso, os flavivírus possuem epítopos comuns na proteína do envelope, o que leva a reações cruzadas nos métodos indiretos de detecção, tais como ELISA, ELISA de Captura (MAC-ELISA) e inibição da hemaglutinação, impossibilitando ou dificultando sua diferenciação (Gubler, 1998). 


\section{OBJETIVOS}

\subsection{OBJETIVOS GERAIS}

- O presente trabalho tem como objetivo validar e implementar a detecção de flavivírus circulantes no Brasil por meio de RT-qPCR, substituindo assim o isolamento viral em camundongos neonatos.

\subsection{OBJETIVOS ESPECÍFICOS}

- Validar a reação de RT-PCR em tempo real com os sistema Taqman para detecção de flavivírus circulantes no Brasil com a utilização de primers universais que amplifiquem o gene codificador da proteína não estrutural 5 (NS5), a mais conservada do gênero;

- Comparar os limites de detecção em unidade formadora de placa (UFP) pelo ensaio com o isolamento viral em cultivos celulares seguido de reação de imunofluorescência IFI;

- Identificar e caracterizar vírus isolados pelo NDTV ainda sem identificação;

- Implantar o método de RT-qPCR na triagem de amostras provenientes de humanos para diagnóstico diferencial;

- Implantar o método de RT-qPCR na triagem de amostras de pesquisa de campo, tais como vetores e/ou sangue de animais reservatórios e sentinelas. 


\section{MATERIAIS E MÉTODOS}

\subsection{AMOSTRAGEM}

Este é um estudo de validação de RT-qPCR para detecção de gênero flavivírus de ocorrência no Brasil, utilizando para isso diluições séricas de vírus previamente titulados em células tipo Vero. O Instituto Adolfo Lutz (IAL), órgão ligado à Secretaria de Saúde do estado de São Paulo, atua na promoção da saúde, sendo, além de um Instituto de Pesquisa, um Laboratório Central de Saúde Pública, credenciado pelo Ministério da Saúde, juntamente com seus doze laboratórios regionais, sediados em municípios estratégicos do Estado. O mesmo lidera as ações de vigilância sanitária, epidemiológica e ambiental, respondendo dessa forma a diversas emergências de agravos importantes para a saúde da população. Uma vez que o Núcleo de Doenças de Transmissão Vetorial (NDTV) do Centro de Virologia do Instituto Adolfo Lutz (IAL) é um centro de referência macrorregional para a vigilância de arboviroses, o mesmo possui um banco de vírus isolados pelo próprio desde sua criação ou que foram fornecidos por instituições de pesquisa, sendo mantidos em passagens em camundongos neonatos ou em culturas de células, mantidos em freezer $-70^{\circ} \mathrm{C}$ nas dependências do IAL. O NDTV recebe amostras de vários estados da federação para confirmação e/ou diagnóstico diferencial de doenças causadas por arbovírus, além de amostras de animais e mosquitos coletados a campo quando solicitado por órgãos governamentais, para monitoramento viral. A Figura 2 mostra a rede de laboratórios de saúde pública brasileiros e sua área de atuação. 
Figura 2 - Rede de laboratórios brasileiros macro-regionais.

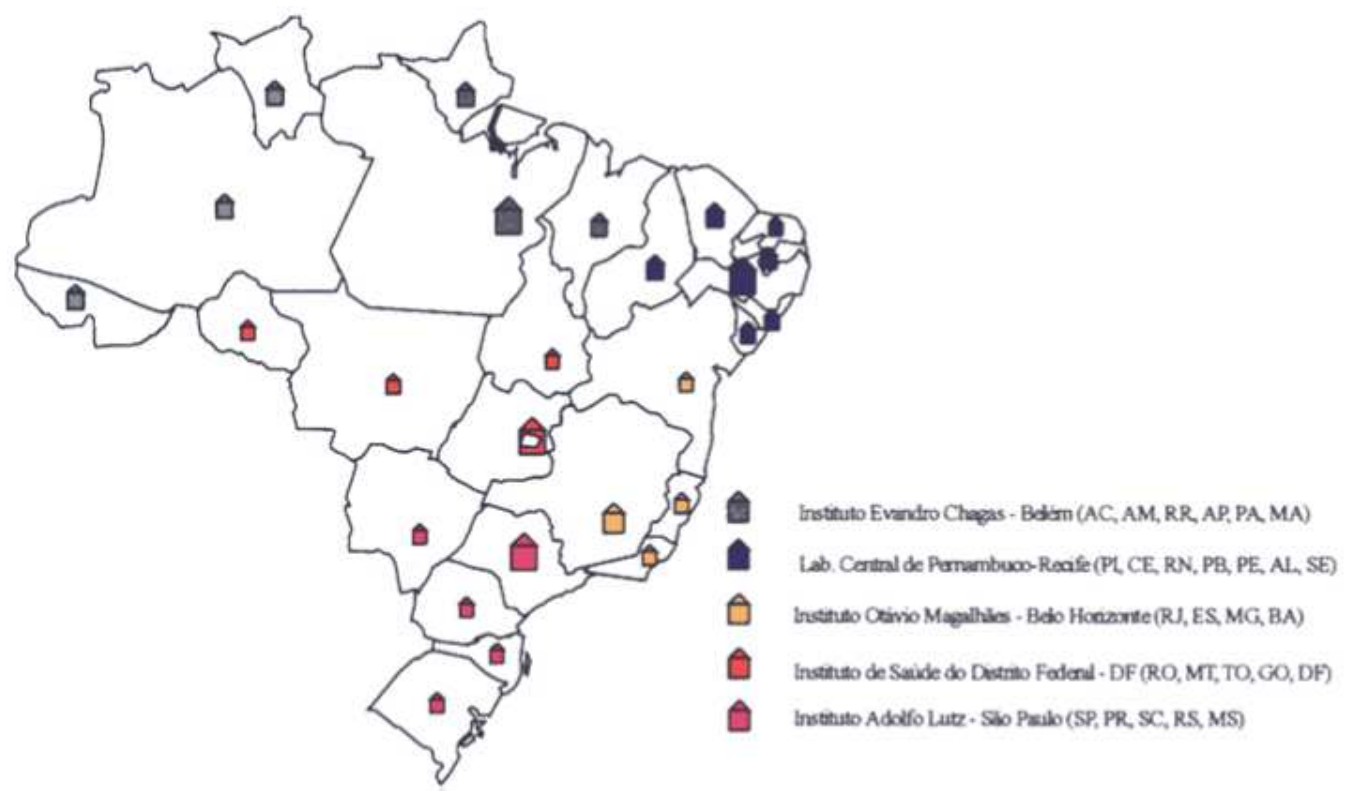

Fonte: dos Santos, 1997

\subsection{AMOSTRAS VIRAIS}

\subsubsection{Vírus padrões}

Para obtenção das curvas padrões de eficiência, foram utilizados os vírus padrões Cacipacore (BeAn 327600), vírus Iguape (SPAN71683), vírus Ilheus (BeH7445), vírus Bussuquara (BeAn 4116), vírus da Febre Amarela (vírus vacinal 17D), vírus da encefalite de Saint Louis (SPAN 11916) e vírus Zika (SPH341957). A Tabela 1 mostra os vírus usadas no presente estudo para a validação da técnica de RT-qPCR.

Para avaliar a viabilidade daqueles que se encontravam mantidos em cérebros de camundongos neonatos, foi feita maceração do sistema nervoso central (SNC) em Cabine de Segurança Biológica com uso de pistilo e cadinho em bacia contendo gelo, adicionando-se de $1,0 \mathrm{ml}$ a $1,5 \mathrm{~mL}$ de meio 199 , centrifugados em tubos tipo Falcon a 10.000 rpm por 30 minutos e filtrados com micro filtro de 25 
nanômetros, ou com adição de gentamicina, se necessário, para posterior inoculação em culturas de células.

Tabela 1 - Vírus utilizados no presente estudo, fonte, passagem e data.

\begin{tabular}{llclc}
\hline \multicolumn{1}{c}{ Vírus } & \multicolumn{1}{c}{ Amostra } & Passagem & \multicolumn{1}{c}{ Fonte } & Data \\
\hline VBQS & BeAn 4073 & 22 & camundongo & 12/11/2001 \\
VESL & SPAn 11916 & ni & C6/36 & ni \\
VIGP & SPAN71683 & 13 & camundongo & $01 / 12 / 1995$ \\
VFA & 17D & ni & C6/36 & ni \\
VILH & BeH7445 & ni & C6/36 & ni \\
VCPC & BeAn 327600 & ni & camundongo & ni \\
VZIK & SPH341957 & 1 & C6/36 & 02/04/2015 \\
\hline Legenda: ni: não informado; An: animal; H: humano; SP: São Paulo; Be: Belém
\end{tabular}

4.2.2 Amostras testadas a partir de mosquitos coletados pelas equipes de campo do NDTV

Equipes de campo do NDTV realizaram, com início em maio de 1970 até recentemente, coletas de vetores e amostras de aves e mamíferos, que são possíveis reservatórios, em diferentes municípios do estado de São Paulo, como parte de programas de vigilância de arboviroses para detecção viral. Mosquitos e sangue total de aves, principalmente, eram preparados e inoculados por via intracerebral em camundongos neonatos de até 3 dias, que ficavam em observação por até 21 dias. Animais que fossem a óbito ou que apresentassem sinais condizentes com isolamento viral, especialmente paralisia ou paresia, eram eutanasiados para posterior identificação pela técnica de Fixação de Complemento. No entanto, alguns deles nunca foram testados. As amostras encontradas e testadas por RT-qPCR no presente estudo, após a maceração de SNC citada acima, estão demonstradas na Tabela 2. 
Tabela 2 - Amostras inoculadas em camundongos neonatos, com possível isolamento positivo para arbovírus, provenientes de mosquitos capturados pelo NDTV.

\begin{tabular}{|c|c|c|c|}
\hline Amostra & Ano & Fonte & Município \\
\hline SPAR158482 & 1994 & Anopholes cruzii & Juquitiba \\
\hline SPAR158486 & 1994 & Anopholes cruzii & Juquitiba \\
\hline SPAR158517 & 1994 & Anopheles triannulatus & Juquitiba \\
\hline SPAR158584 & 1994 & Anopholes cruzii & Juquitiba \\
\hline SPAR158533 & 1994 & Coquillettidia juxtamansonia & Juquitiba \\
\hline SPAR158495 & 1994 & Anopholes cruzii & Juquitiba \\
\hline SPAR147628 & 1991 & $\begin{array}{l}\text { Haemagogus capricornii/Sabethes } \\
\text { spp. }\end{array}$ & Araçatuba \\
\hline SPAR150983 & 1994 & Coquillettidia sp. & Iguape \\
\hline SPAR158470 & 1994 & Anopholes cruzii & Juquitiba \\
\hline SPAR172852 & 1997 & Aedes scapularis & Guarulhos \\
\hline SPAR172766 & 1997 & Culex declarator & Guarulhos \\
\hline SPAR158495 & 1994 & Anopholes cruzii & Juquitiba \\
\hline SPAR158477 & 1994 & Anopholes cruzii & Juquitiba \\
\hline SPAR158584 & 1994 & Culex sp. & Juquitiba \\
\hline
\end{tabular}

Legenda: AR: artrópode; SP: São Paulo.

\subsubsection{Amostras enviadas ao NDTV pela rede ou por demais órgãos}

Como dito anteriormente, o NDTV recebe amostras de pacientes para diagnóstico e/ou diagnóstico confirmatório e de animais e mosquitos para monitoramento viral e pesquisa.

Em março de 2015, um paciente do sexo masculino, 52 anos, doou sangue no Hemocentro da Unicamp, em Campinas, voltando no dia seguinte com quadro febril compatível com dengue. Dessa forma, uma amostra de soro foi encaminhada ao NDTV-IAL/SP para diagnóstico de dengue, sendo portanto encaminhada aos testes de RT-qPCR multiplex para dengue (JOHNSON; RUSSELL; LANCIOTTI, 2005), sorologia por ELISA e para isolamento em células C6/36. Com exceção do isolamento, positivo para flavivírus em IFI, os demais tiveram resultado negativo e, dessa forma, esta amostra foi incluída no presente trabalho para elucidação do caso, 
visando uma resposta para o diagnóstico do paciente em questão.

Em 2016, 5 amostras de soro e/ou líquor de 3 equinos internados no Hospital Veterinário da USP (HOVET) com quadro neurológico foram encaminhadas ao NDTV-IAL para possível elucidação de encefalite causada por flavivírus, sendo também utilizadas no presente trabalho.

Além disso, dois pools de mosquitos capturados pela Superintendência de Controle de Endemias (SUCEN) no município de Guapiaçu, frente ao surto de febre amarela que se iniciou no Estado de São Paulo em 2016, e que continua até o presente momento, foram testados com o presente protocolo após terem seu isolamento confirmado em células $\mathrm{C6/36}$ seguido de IFI com uso de anticorpos policlonais para flavivírus, mas que foram negativos com uso de monoclonais para os vírus Dengue sorotipos 1, 2, 3 e 4 e vírus da Febre Amarela. A Tabela 3 mostra a relação de amostras recebidas pelo NDTV para diagnóstico e monitoramento viral utilizadas no presente estudo.

Tabela 3 - Relação de amostras encaminhadas ao NDTV para diagnóstico ou monitoramento viral.

\begin{tabular}{cccc}
\hline Amostra & Ano & Fonte & Município \\
\hline 03/17829 & 2015 & soro & Campinas \\
cavalo USP 1 & 2016 & soro & São Paulo \\
cavalo USP 2 & 2016 & líquor & São Paulo \\
cavalo USP 2 & 2016 & soro & São Paulo \\
cavalo USP 3 & 2016 & soro & São Paulo \\
cavalo USP 3 & 2016 & líquor & São Paulo \\
SPAR01/17 & 2017 & Aedes terrens & Guapiaçu \\
SPAR02/17 & 2017 & Aedes scapularis & Guapiaçu \\
\hline
\end{tabular}

\subsection{INOCULAÇÃO EM CULTIVOS CELULARES}

Alíquotas de $200 \square \mathrm{L}$ de cada vírus (macerado de SNC ou fluidos de C6/36) utilizados no presente estudo foram inoculadas em garrafas para cultivo celular com 
área de $25 \mathrm{~cm}^{2}$ contendo monocamada pré-formada de células Vero (até passagem número 150), fornecidas pelo Núcleo de Cultura de Células do Instituto Adolfo Lutz, para propagação viral, que foram incubadas em estufa úmida de $\mathrm{CO} 2$ a $36^{\circ} \mathrm{C}$ por 1 hora para adsorção. Após esse período, o inóculo foi vertido em solução de hipoclorito a $10 \%$, sendo adicionados $5 \mathrm{~mL}$ de meio 199 , acrescido de $2,5 \%$ de soro fetal e gentamicina (1mL/L). As mesmas foram observadas diariamente por período de até 10 dias para visualização de efeito citopático, até que este tivesse atingido pelo menos $75 \%$ da monocamada. Neste momento, o sobrenadante foi coletado, centrifugado a 2500 rpm por 10 minutos e separado em alíquotas de $200 \mu \mathrm{L}$ em tubos criogênicos e congelados em freezer a $-70^{\circ} \mathrm{C}$ para posterior titulação. Caso 0 título tenha se mostrado baixo, uma nova passagem foi feita até a obtenção de um valor adequado para obtenção da curva padrão no teste de RT-qPCR.

\subsection{CÁLCULO DO TíTULO VIRAL}

\subsubsection{Titulação por Unidade Formadora de Placa (UFP)}

Os títulos do VFA, VILH, VIGP, VZIK, VESL e VCPC foram calculados por unidade formadora de placa (UFP) por $\mathrm{mL}$ após passagens cegas sucessivas citadas anteriormente. Brevemente, as amostras puras dos vírus utilizados foram diluídas seriamente na base 10 em meio de cultura 199 e inoculadas em microplacas de 24 orifícios contendo células Vero (até passagem número 150), fornecidas pelo Núcleo de Culturas Celulares do Instituto Adolfo Lutz. Após retirada do meio de crescimento, foram inoculados $100 \mu \mathrm{L}$ de cada diluição viral em triplicata, até a diluição $10^{-8}$. As mesmas foram colocadas a $37^{\circ} \mathrm{C}$ em estufa úmida de $\mathrm{CO}^{2}$ a $5 \%$ por 1 hora, com agitações a cada 15 minutos. Após isso, foi acrescentado $1 \mathrm{~mL}$ de meio 199 com 0,5\% de metilcelulose, 2,5\% de soro fetal bovino e gentamicina $(1 \mathrm{~mL} / \mathrm{L})$. As microplacas foram então incubadas por 5 a 7 dias na mesma estufa, com exceção do vírus Zika, que foi incubado por 8 dias, até a contagem das placas. O meio de manutenção foi removido vertendo-se a placa em recipiente contendo hipoclorito a $10 \%$, lavando-se os orifícios com água deionizada. Adicionaram-se 500 $\mu \mathrm{L}$ de acetona para fixação durante 10 minutos, e os poços foram novamente 
lavados com água deionizada. Posteriormente, foram adicionados $200 \mu \mathrm{L}$ de cristal violeta para coloração e visualização das, que foi removido após 5 minutos, e a placa lavada novamente com água deionizada. Escolheu-se a diluição em que foram contadas de 10 a 50 unidades de placas, tirando-se uma média entre elas para se calcular o valor de UFP por mL. A Figura 3 mostra placas formadas pelo vírus Zika isolado SPH341957 em microplacas de células Vero.

Figura 3 - Placas formadas por Vírus Zika SPH341957 em células Vero.

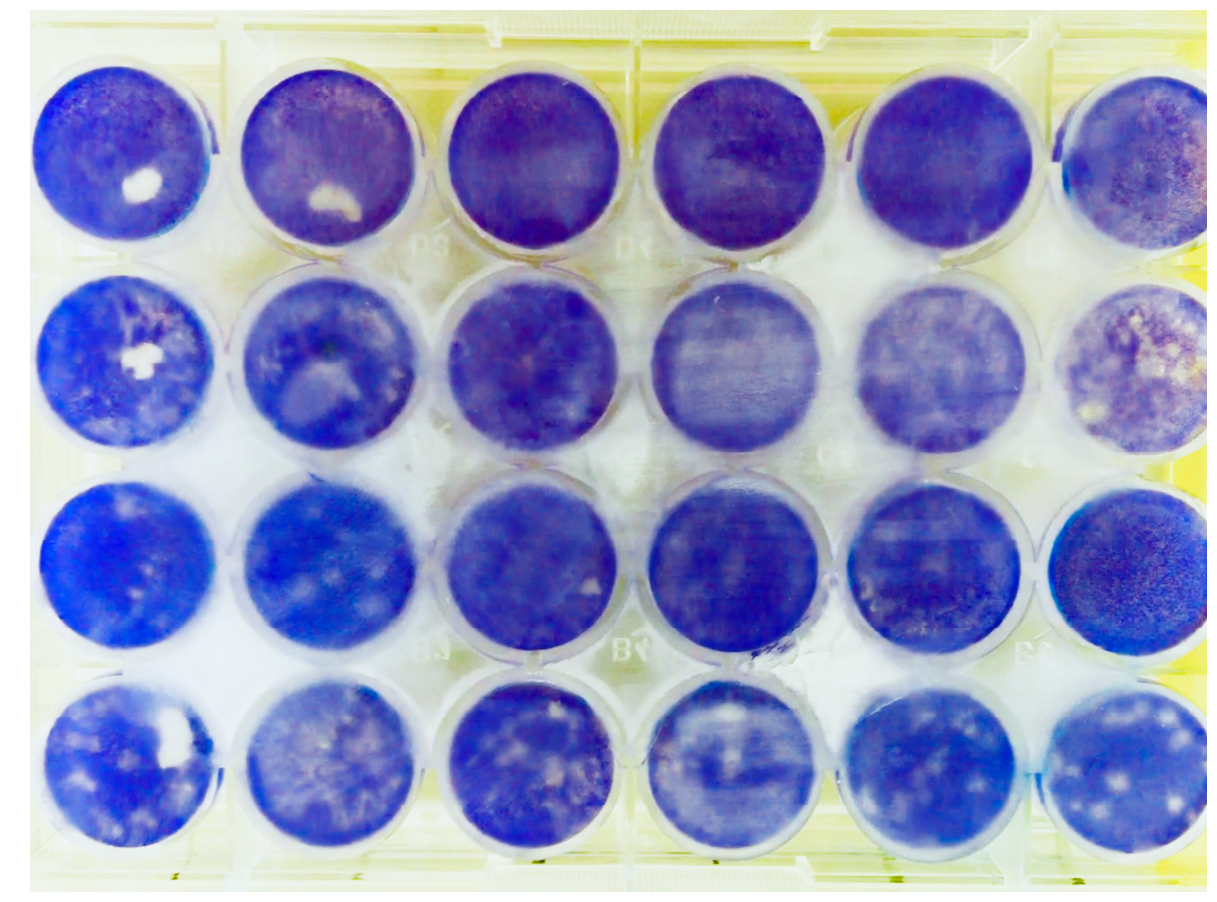

4.4.2 Titulação por Dose Infectante por cultura de Tecido 50\% (TCID50)

O vírus Bussuquara foi titulado por TCID50, segundo método descrito por Reed e Muench (1938). A amostra pura foi diluída seriamente na base 10 em meio de cultura 199 e inoculadas em microplaca de 24 orifícios contendo células Vero (até passagem número 150), fornecida pelo Núcleo de Culturas Celulares do Instituto Adolfo Lutz. Após retirada do meio de crescimento, foram inoculados $100 \mu \mathrm{L}$ de cada diluição viral em triplicata, até a diluição $10^{-8}$. A microplaca foi colocada a $37^{\circ} \mathrm{C}$ em estufa úmida de $\mathrm{CO}^{2}$ a $5 \%$ por 1 hora, com agitações a cada 15 minutos. Após isso, foi acrescentado com adição de meio 199 acrescido de $2,5 \%$ de soro fetal bovino e 
gentamicina (1mL/L), avaliando-se presença de efeito citopático em cada poço após 5 dias de inoculação. A Figura 4 mostra o efeito citopático causado em células Vero.

Figura 4 - Efeito citopático observado em células Vero causado por Flavivírus

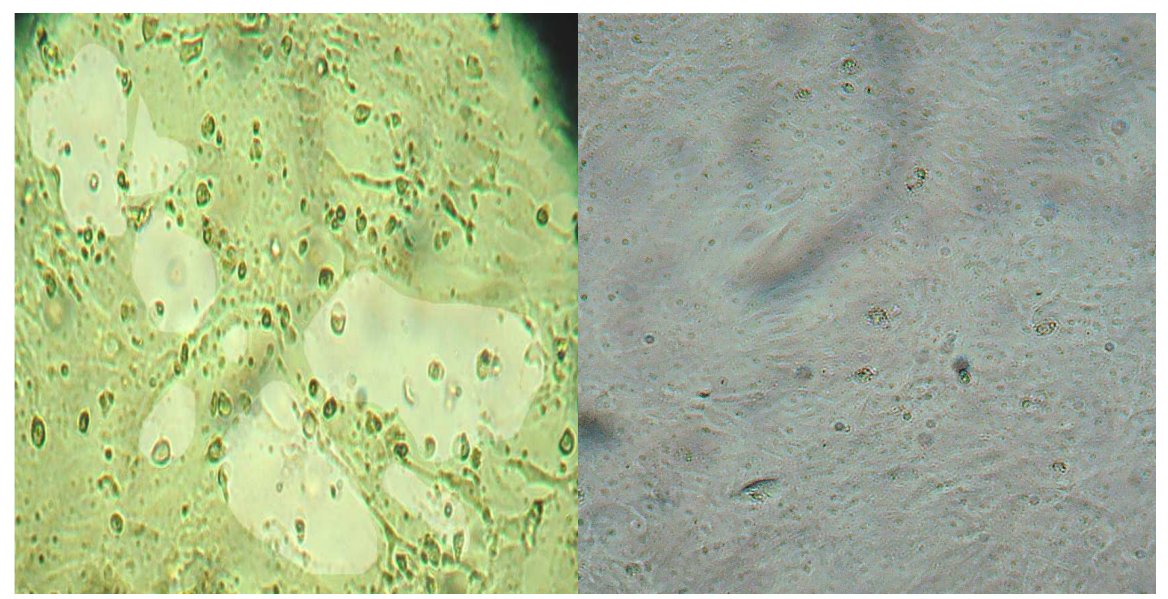

Legenda: à esquerda, célula Vero infectada com vírus da Encefalite de Saint Louis isolado SPAN 11916. À direita, controle negativo

\subsection{INOCULAÇÃO EM CÉLULAS C6/36 SEGUIDA DE IMUNOFLUORESCÊNCIA INDIRETA (IFI)}

Visando uma comparação dos limites de detecção de cada flavivírus utilizado, uma alíquota de cada diluição já titulada de todos deles foi diluída novamente seriamente na base de 10. Posteriormente, $100 \mu \mathrm{L}$ de cada diluição foram inoculados em microplacas de 24 orifícios contendo tapete formado por células C6/36 após remoção do meio de crescimento, sendo inoculado um controle positivo de VFA, e dois orifícios somente com meio para controles negativos. Após 1 hora de adsorção em estufa a $28^{\circ} \mathrm{C}$, foi inoculado $1 \mathrm{~mL}$ de meio Leibovitz (L-15), acrescido de $2,5 \%$ de soro fetal bovino e gentamicina $(1 \mathrm{~mL} / \mathrm{L})$, e colocadas novamente em estufa a $28^{\circ} \mathrm{C}$, embaladas em papel filme. Após 7 dias da inoculação, as células foram desprendidas da microplaca com uso de pipeta Pasteur, sendo cada amostra adicionada, em duplicata, em lâminas de 12 poços, que ficaram em CSB até secar. Após isso, as mesmas foram fixadas em acetona por 10 minutos a $-20^{\circ} \mathrm{C}$. Em seguida, foi acrescida uma gota de fluido ascético imune anti-flavivírus (pool de 
soros imunes dos vírus DENV-1, DENV-2, DENV-3 e DENV-4 ou anti-SLEV SPH253175) produzidos no NDTV, previamente diluídos. No controle negativo, adicionou-se PBS. As lâminas foram então incubadas a $37^{\circ} \mathrm{C}$ em câmara úmida, por 30 minutos. Posteriormente, foram lavadas com PBS por 5 minutos e mergulhadas em cuba com água deionizada. Após secagem, foi adicionada uma gota de anti-IgG de camundongo conjugado com fluoresceína (Sigma-Aldrich®, Saint Louis, Missouri, EUA), na diluição de 1:32 conforme instrução do fabricante, em cada orifício, e novamente incubadas a $37^{\circ} \mathrm{C}$ em câmara úmida, por 30 minutos. As lâminas foram novamente lavadas em PBS e água deionizada. Por fim, colocou-se uma gota de glicerina tamponada em lamínulas fixando-as em cada lâmina, e a leitura foi feita em microscópio de imunofluorescência em sala escura, no aumento de 40x, considerando-se orifícios positivos aqueles com presença de pelo menos uma célula infectada. A Figura 5 ilustra células C6/36 infectadas com vírus Zika e Bussuquara.

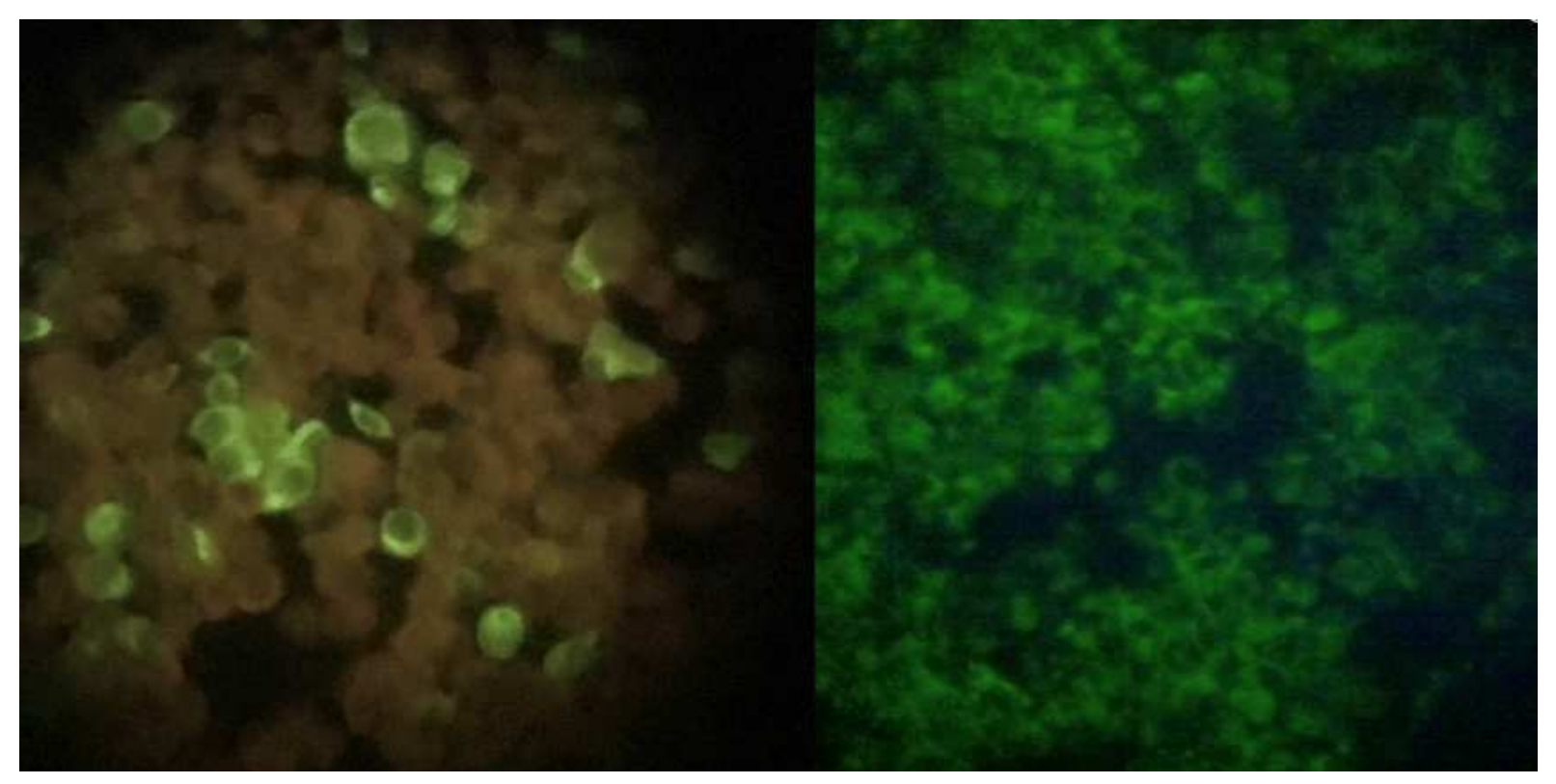

Figura 5 - Reação de imunofluorescência indireta positiva, utilizando-se células C6/36. Legenda: à esquerda: IFI para vírus Bussuquara $\left(10^{-3}\right)$; à direita, IFI para vírus Zika $\left(10^{-1}\right)$.

\subsection{EXTRAÇÃO DE ÁCIDO NUCLEICO VIRAL}

Para a extração viral das alíquotas de cada uma das amostras diluídas dos vírus padrões, dos macerados de SNC de camundongos com suspeita de 
isolamento e dos fluidos de cultura de células, foi utilizado o kit comerciai QIAamp viral RNA mini kit (QIAGEN®, Hilden, Alemanha), de acordo com as instruções do fabricante. Brevemente, foram adicionados $140 \mu \mathrm{l}$ de cada diluição de título conhecido (de $10^{-1}$ a $10^{-8}$ ) e de cada uma das demais amostras a tubos de 1,5 ml contendo 5,6 $\mu$ l de carregador de RNA, acrescidos a 560 $\mu$ l de tampão de digestão, com posterior uso de Vortex por 15 segundos, e incubado por 10 minutos a temperatura ambiente. Em seguida, adicionaram-se $560 \mu \mathrm{l}$ de etanol 100\%, transferindo $630 \mu \mathrm{l}$ da solução, cuidadosamente, ao centro da coluna sílica gel identificada previamente. A mesma foi centrifugada a 6.000xg por 1minuto, e transferida a um novo tubo coletor. Após descarte do sobrenadante, foi transferido o restante da solução ao centro da coluna, que foi novamente centrifugada a $6.000 \mathrm{xg}$ por 1 minuto. O tubo coletor contendo o filtrado foi descartado, e foram adicionados $500 \mu l$ do tampão de lavagem AW1. A coluna foi novamente centrifugada e o procedimento descrito acima repetido, adicionando-se $500 \mu l$ do tampão de lavagem AW2. A coluna foi então centrifugada a $10.000 \times \mathrm{xg}$ por 3 minutos, o filtrado foi descartado, e novamente foi feita uma centrifugação a 10.000xg por 1 minuto para secagem da mesma. Em seguida, a coluna foi transferida a um tubo de $1,5 \mathrm{~mL}$ identificado, na qual foram adicionados $60 \mu$ de tampão de eluição AVE incluso no kit, e incubado por 1 minuto em temperatura ambiente. Foi feita outra centrifugação a $6.000 \times$ g por 1 minuto. A coluna foi descartada e o RNA coletado foi congelado a $70^{\circ} \mathrm{C}$ até o uso. Para cada tipo viral foi extraído junto um controle negativo da reação.

\subsection{TRANSCRIÇÃO REVERSA SEGUIDA DA REAÇÃo EM CADEIA PELA POLIMERASE EM TEMPO REAL (RT-qPCR)}

Para o presente estudo, foram selecionados oligonucleotídeos iniciadores que amplifiquem o gene codificador da proteína não estrutural 5 (NS5) e, após uma análise in silico dos mesmos, escolheu-se o descrito por Patel e colaboradores (2013). As informações acerca dos oligonucleotídeos iniciadores estão descritas na Tabela 4. 
Tabela 4 - Sequência e posição de anelamento dos oligoiniciadores utilizados no estudo.

\begin{tabular}{|c|c|c|}
\hline Primer & Sequência & $\begin{array}{l}\text { Posição } \\
\text { Genoma }\end{array}$ \\
\hline & & $8993-$ \\
\hline senso: Flavi all S & 5'- TACAACATgATggggAARAgAgARAA - 3 & 9019 \\
\hline antissenso: Flavi & & 9232- \\
\hline all S2 & 5'- gTgTCCCAgCCNgCKgTgTCATCWgC - 3 & 9260 \\
\hline & FAM-Tg + gTWYATgT + ggYTNg + gRgC- & $9062-$ \\
\hline probe 3 & $\mathrm{BBQ}$ & 9082 \\
\hline
\end{tabular}

\subsection{ENSAIO DE RT-PCR EM TEMPO REAL (RT-QPCR)}

Para a realização das reações $\mathrm{RT}$-qPCR deste estudo, foi utilizado o equipamento $\mathrm{ABI}$ StepOne (Applied Biosystems®), Foster City, Califórnia, EUA), disponível no Centro de Virologia do Instituto Adolfo Lutz. O protocolo utilizado para a reação com volume final de $25 \mu \mathrm{L}$ utilizando-se o par de iniciadores iniciadores Flav all S e Flav all S2, com probe do tipo Taqman marcada na região 5'terminal com a molécula sinalizadora 6-carboxifluoresceína (FAM) e na região 3'terminal com Blackhole Quencher 1 (BHQ1). Para um volume final de $25 \mu \mathrm{L}$, foram utilizados 12,5 $\mu \mathrm{L}$ de Master Mix (SuperScript® III Platinum® One-Step Quantitative RT-PCR System with Rox, Thermo Fisher Scientific, Walthan, Massachutes, EUA), 0,5 $\mu \mathrm{L}$ de cada iniciador na concentração de $25 \mu \mathrm{M}, 0,5 \mu \mathrm{L}$ de probe na concentração de 10 $\mu \mathrm{M}$ e água grau puro para completar o volume, com acréscimo de $5 \mu \mathrm{L}$ de RNA extraído. As condições de ciclagem foram: 1 ciclo de $50^{\circ} \mathrm{C}$ por 10 minutos, seguido de $95^{\circ} \mathrm{C}$ por 2 minutos, e 45 ciclos de $95^{\circ} \mathrm{C}$ por 10 segundos e $60^{\circ} \mathrm{C}$ por 30 segundos.

Para cada reação de RT-qPCR para detecção de flavivírus foram utilizados 4 controles de reagentes e ambiente (NTC - no template control) e como controle positivo o YFV. Foram usados, ainda, para avaliação da especificidade os alphavirus 
Chikungunya (CHIKV) e Mayaro (MAYV), que também são arbovírus com circulação no país com quadros semelhantes aos causados pelas infecções por flavivírus.

\subsection{INTERPRETAÇÃO DOS RESULTADOS}

Os resultados obtidos após a reação de RT-qPCR foram interpretados como positivos a partir da formação de uma curva sigmóide observada no software do aparelho ABI StepOne v2.3. (Applied Biosystems ${ }^{\circledR}$, Foster City, Califórnia, EUA). Após o ajuste manual do Threshold, foram anotados os valores de Ct (Cycle Threshold), que corresponde ao ciclo em que a fluorescência ultrapassa a linha do Threshold, que permite correlacionar o aumento da mesma com a quantidade inicial de DNA alvo. Foram considerados como positivos Cts até o valor de 39,7, de acordo com Patel e colaboradores (2010), valor este que corresponde a 10 cópias de RNA para o vírus da Dengue sorotipo 1.

\subsection{VALIDAÇÃO DOS ENSAIOS DE RT-QPCR E ANÁLISE ESTATÍSTICA}

Para avaliar a eficiência dos protocolos de RT-qPCR para todos os flavivírus padrões utilizados no presente estudo, foi feita uma curva de diluição em série de 10 a partir dos resultados positivos obtidos, em triplicata, composta pelas diluições de $10^{-1}$ a $10^{-8}$, escolhendo-se no mínimo 5 pontos para o cálculo da mesma, de acordo com a diluição máxima em que houve amplificação, considerando-se, hipoteticamente, que a mesma contém aproximadamente 1 cópia de RNA viral.

Os resultados das análises prévias foram expressos de acordo com seu limite de detecção. Para análise estatística referente à eficiência dos protocolos de RTPCR em tempo real, inclinação da curva (Slope) e coeficiente de correlação $\left(R^{2}\right)$, foi utilizado o software do equipamento $A B I$ StepOne v2.3. Uma eficiência de $100 \%$ revela que a quantidade de produto gerado aumentado exponencialmente dobra a cada ciclo. Na prática, valores ideais estão entre 90 a 110\%. Seu valor é calculado segundo a equação Eficiência $=10^{(-1 / \text { slope })}-1$. Dessa forma, um valor de Slope de - 
3,32 equivale a $100 \%$ de eficiência, $-3,5$ equivale a $93 \%$ de eficiência e $-4,0$ a $78 \%$, e assim por diante. Uma PCR com baixa eficiência terá uma sensibilidade menor.

O coeficiente de correlação $\left(R^{2}\right)$ é a medida de como os pontos se ajustam à curva padrão, refletindo a linearidade da curva. Um $R^{2}>0,99$ indica boa confiança ao correlacionar os valores de $\mathrm{Ct}$ e a quantidade. Se ele for igual a 0 , o valor de $\mathrm{Ct}$ não pode predizer o valor da quantidade.

A comparação dos limites de detecção de cada vírus padrão (em UFP/mL) deste ensaio foi feita com os resultados obtidos na IFI, conforme descrito no item 4.5, uma das técnicas de detecção etiológica utilizada na rotina do laboratório para isolamento viral de amostras provenientes de diversos locais para diagnóstico ou para fins de vigilância.

\subsection{ENSAIO DE RT-PCR}

Visando a confirmação de vírus identificados a partir de mosquitos Aedes terrens e Aedes scapularis capturados em Guapiaçu, SP, em 2017, amostras estas positivas em isolamento em células C6/36 sem confirmação do tipo viral, uma vez que o fragmento de cDNA gerado após a reação de RT-qPCR não foi suficiente para tal, foi feita uma RT-PCR para a NS5 e NCR 3` segundo protocolo descrito por Kuno e colaboradores (1998a), cujos oligoinicadores estão descritos na Tabela 5, utilizando-se, para um volume final de $30 \mu \mathrm{L}, 3 \mu \mathrm{L}$ de tampão 10X concentrado (Platinum Taq DNA Polymerase Thermo Fisher Scientific, Walthan, Massachutes, EUA, $0,9 \mu \mathrm{L}$ de $\mathrm{MgCl}_{2}$ a $50 \mathrm{mM}$ (Thermo Fisher Scientific, Walthan, Massachutes, EUA), 1,5 $\mu \mathrm{L}$ de DTT 0,1M (Thermo Fisher Scientific, Walthan, Massachutes, EUA), 0,6 $\mu \mathrm{L}$ de mix de DNTP 10mM (Thermo Fisher Scientific, Walthan, Massachutes, EUA), 0,9 $\mu \mathrm{L}$ de cada iniciador na concentração de $20 \mu \mathrm{M}, 0,375 \mu \mathrm{L}$ da enzima RT (Thermo Fisher Scientific, Walthan, Massachutes, EUA), 0,25 $\mu \mathrm{L}$ de Taq Platinum $5 \mathrm{u} / \mu \mathrm{L}$ (Thermo Fisher Scientific, Walthan, Massachutes, EUA) e água grau puro para completar o volume, com acréscimo de $3 \mu \mathrm{L}$ de RNA extraído. As condições de ciclagem foram: 1 ciclo de $50^{\circ} \mathrm{C}$ por 30 minutos, seguido de $94^{\circ} \mathrm{C}$ por 2 minutos, e 35 ciclos de $94^{\circ} \mathrm{C}$ por 30 segundos, $45^{\circ} \mathrm{C}$ por 60 segundos e $72^{\circ} \mathrm{C}$ por 2 minutos, e um 
ciclo de $72^{\circ} \mathrm{C}$ por 7 minutos. A visualização das bandas foi feita por uso de gel de agarose a 1,25\% corado com GelRed (Thermo Fisher Scientific, Walthan, Massachutes, EUA), observadas sob luz ultravioleta em transiluminador. A imagem gerada foi captada pelo sistema de fotodocumentação digital UV Transiluminator, UVP, Laboratory Products. A positividade dos fragmentos gerados foram comparados ao peso molecular e com o controle positivo utilizado para cada reação.

Tabela 5 - Oligoiniciadores descritos por Kuno et al. (1998a) utilizados para confirmação de flavivírus isolados a partir de mosquitos Aedes sp. capturados no município de Guapiaçu em 2017.

\begin{tabular}{ccc}
\hline Oligoniciadores & $\begin{array}{c}\text { Posição do } \\
\text { Genoma }\end{array}$ & $\begin{array}{c}\text { Tamanho do } \\
\text { Fragmento }(\mathrm{pb})\end{array}$ \\
\hline FU1PM F & 8993 & 265 \\
cFD2 R & 9258 & \\
FU1PM F & 8993 & 655 \\
cFD4 R & 9648 & \\
FU2 F & 9233 & 415 \\
cFD4 R & 9648 & 448 \\
FU3PM F & 9629 & \\
cFD3PM R & 10077 & 1099 \\
FU3PM F & 9629 & \\
VD8 R & 10728 & \\
\hline
\end{tabular}

\subsection{SEQUENCIAMENTO DE DNA}

Os fragmentos de cDNA obtidos após as reações de RT-qPCR, diretamente coletados a partir da placa de 96 orifícios de tempo real, bem como os gerados pela RT-PCR para NS5, foram submetidos à reação cíclica de sequenciamento usando o kit comercial BigDye ${ }^{\circledR}$ Terminator v3.1 Cycle Sequencing Ready Reaction Kit (Thermo Fisher Scientific, Walthan, Massachutes, EUA), utilizando-se os mesmo oligoiniciadores das reações de RT-PCR e RT-qPCR. Foi realizada a mistura para sequenciamento em microtubos contendo $2 \mu \mathrm{L}$ de BigDye® (Thermo Fisher Scientific, Walthan, Massachutes, EUA); $6 \mu \mathrm{L}$ de tampão 5x concentrado (Thermo 
Fisher Scientific, Walthan, Massachutes, EUA); $1 \mu \mathrm{L}$ de primer e água MilliQ estéril. Os mesmos foram levados ao termociclador (Perkin Elmer Cetus, modelo GeneAmp PCR System 9600), o qual foi programado para amplificação em 25 ciclos $\left(96^{\circ} \mathrm{C}\right.$ por 10 segundos, $50^{\circ} \mathrm{C}$ por 5 segundos, $64^{\circ} \mathrm{C}$ por 4 minutos).

\subsection{PURIFICAÇÃO E PRECIPITAÇÃO DO PRODUTO DA REAÇÃO DE SEQUENCIAMENTO}

Os produtos de sequenciamento foram purificados utilizando-se colunas de centrifugação Centri-SepTM spin columns (Thermo Fisher Scientific, Walthan, Massachutes, EUA), de acordo com o protocolo descrito pelo fabricante. As colunas de purificação foram previamente hidratadas com $800 \mu \mathrm{L}$ de água milliQ estéril por 30 minutos à temperatura ambiente. Após a hidratação, as colunas foram acopladas a tubos coletores e centrifugadas em microcentrífuga (Eppendorf, modelo Centrifuge $5415 \mathrm{C})$ a $3.000 \mathrm{rpm}$ por 3 minutos a temperatura ambiente. Os tubos coletores foram removidos e as colunas foram transferidas para novos microtubos. Adicionaram-se $20 \mu \mathrm{L}$ do produto de cada cycle sequencing nos microtubos contendo a coluna de purificação, seguindo-se de centrifugação em microcentrífuga (Eppendorf, modelo Centrifuge 5415 C) a 3.000 rpm por 3 minutos. O filtrado contendo o produto de sequenciamento foi seco por centrifugação em centrifuga a vácuo (Eppendorf, modelo Concentrator 5301) a $45^{\circ} \mathrm{C}$ por 2,5 horas. O produto precipitado foi armazenado em freezer $-20^{\circ} \mathrm{C}$ até o momento de sequenciar.

$\mathrm{Na}$ etapa final os produtos marcados (Dye) e ressuspendidos em $10 \mu \mathrm{L}$ de formamida Hi-DiTM (Applied Biosystems, Foster City, Califórnia, EUA), foram aplicados no analisador automático de DNA (sequenciador automático) modelo $\mathrm{ABI}$ Prism 3100 (Applied Biosystems, Foster City, Califórnia, EUA) utilizando o polímero POP6 (Applied Biosystems, Foster City, Califórnia, EUA).

\subsection{ANÁLISE DAS SEQUÊNCIAS E FILOGENIA}


De posse dos cromatogramas das amostras de flavivírus a serem identificadas, foi feita uma inspeção visual das sequências geradas para cada fita senso e antissenso através do aplicativo Sequencher. Após isso, a especificidade do amplicon foi avaliada através das ferramentas online Blast e Blastx (Basic Local Alignment Search Tool) para identificação do vírus a partir das sequências de NS5 geradas, avaliando-se nucleotídeos e aminoácidos. Cada alinhamento gera uma medida estatística denominada E-value (valor de expectativa), que indica a probabilidade de encontrar uma sequência igual. Aquelas com valores iguais ou menores que 0,01 têm maior chance de serem homólogas (ALTSCHUL et al., 1990; KARLIN; ALTSCHUL, 1990). Em seguida, elas foram editadas com o programa Bioedit v.7.0.9 (HALL, 1999) e alinhadas entre si e com outras homólogas recuperadas do Genbank, utilizando-se o software CLUSTAL W versão 1.8.3 no programa BioEdit versão v.7.0.9 (HALL, 1999). As matrizes de similaridade de nucleotídeos e de aminoácido foram calculadas usando o programa Bioedit v.7.0.9. A inferência filogenética foi realizada mediante uso do programa Mega versão 7 (KUMAR; STECHER; TAMURA; 2016). As árvores geradas a partir da sequência nucleotídica foi construída com o método de Máxima Parcimônia através do modelo Kimura 2-parâmetros com distribuição gama, enquanto que a de aminoácidos foi construída com o método de Máxima Parcimônia através do modelo de substituição JTT, ambas definidas com os valores de bootstrap de 1.000 repetições. A tabela 6 mostra os vírus utilizados para a construção das árvores filogenéticas e seus respectivos números de acesso no GenBank. 
Tabela 6 - Relação de vírus usados na construção de árvores filogenéticas do presente estudo e seus respectivos números de acesso no GenBank.

\begin{tabular}{cc}
\hline Vírus & Número de Acesso \\
\hline Ilheus & AY632539 \\
Ilheus & EF396952 \\
Ilheus & EF396952 \\
Ilheus & EF396951 \\
Ilheus & JN679229 \\
Ilheus & EF396947 \\
Rocio & KC481679 \\
Long Pine Key & KY290249 \\
Long Pine Key & KY290250 \\
Long Pine Key & KY290251 \\
Long Pine Key & KY290253 \\
Long Pine Key & KY290254 \\
Long Pine Key & KY290255 \\
Long Pine Key & KY290256 \\
Nhumirim & NC024017 \\
Aedes flavivirus & KC181923 \\
Mercadeo & NC027819 \\
Culex flavivirus & HQ634598 \\
Culex flavivirus & HQ634594 \\
\hline
\end{tabular}




\section{RESULTADOS}

\subsection{TITULAÇÃO}

Os títulos obtidos para cada um dos sete flavivírus utilizados no presente estudo para a validação do teste de RT-qPCR e suas respectivas curvas de eficiência encontram-se na Tabela 7.

Tabela 7- Títulos obtidos para cada flavivírus usado no presente estudo.

\begin{tabular}{ll}
\hline \multicolumn{1}{c}{ Vírus } & \multicolumn{1}{c}{ Título } \\
\hline VBSQ & $1 \times 10^{3,6} \mathrm{TCID} 50 / 100 \mu \mathrm{L}$ \\
VESL & $9,4 \times 10^{4} \mathrm{UFP} / \mathrm{ml}$ \\
VIGP & $4,4 \times 10^{8} \mathrm{UFP} / \mathrm{mL}$ \\
VFA & $5,2 \times 10^{6} \mathrm{UFP} / \mathrm{mL}$ \\
VILH & $1,7 \times 10^{4} \mathrm{UFP} / \mathrm{mL}$ \\
VCPC & $3 \times 10^{4} \mathrm{UFP} / \mathrm{mL}$ \\
VZIK & $7,5 \times 10^{5} \mathrm{UFP} / \mathrm{mL}$ \\
\hline
\end{tabular}

Legenda: UFP/mL: unidade formadora de placa por mililitro

TCID 50: Dose Infectante por cultura de Tecido 50\%

\subsection{VALIDAÇÃO DOS ENSAIOS}

\subsubsection{Vírus da Febre Amarela 17D}

O VFA, cujo título foi de $5,2 \times 10^{6} \mathrm{UFP} / \mathrm{mL}$, teve seu limite máximo de detecção na diluição de $10^{-6}$, que corresponde a 1 UFP. A figura 6 mostra as curvas de amplificação obtidas, em triplicata, enquanto que o Gráfico 1 mostra a curva padrão e valores de Slope $(-3,767)$, Y-intercepto $(16,196)$, valor de coeficiente de correlação $\left(R^{2}\right)(99,6 \%)$ e eficiência da reação $(84,3 \%)$ obtidos com uso dos primers Flavi all S e Flavi all AS2, com sonda Flavi all 3. 
Figura 6 - Perfil linear da absorbância emitida durante cada ciclo no protocolo da curva de concentração decrescente para o protocolo de RT-qPCR para o vírus vacinal da Febre Amarela, utilizando-se os primers Flavi all S e Flavi all AS2, com sonda Flavi all 3. Estão incluídas 3 repetições para as diluições do vírus, de $10^{-1}$ a $10^{-8}$. Registro de resultado de experimento interpretado pelo software ABI StepOne v2.3.

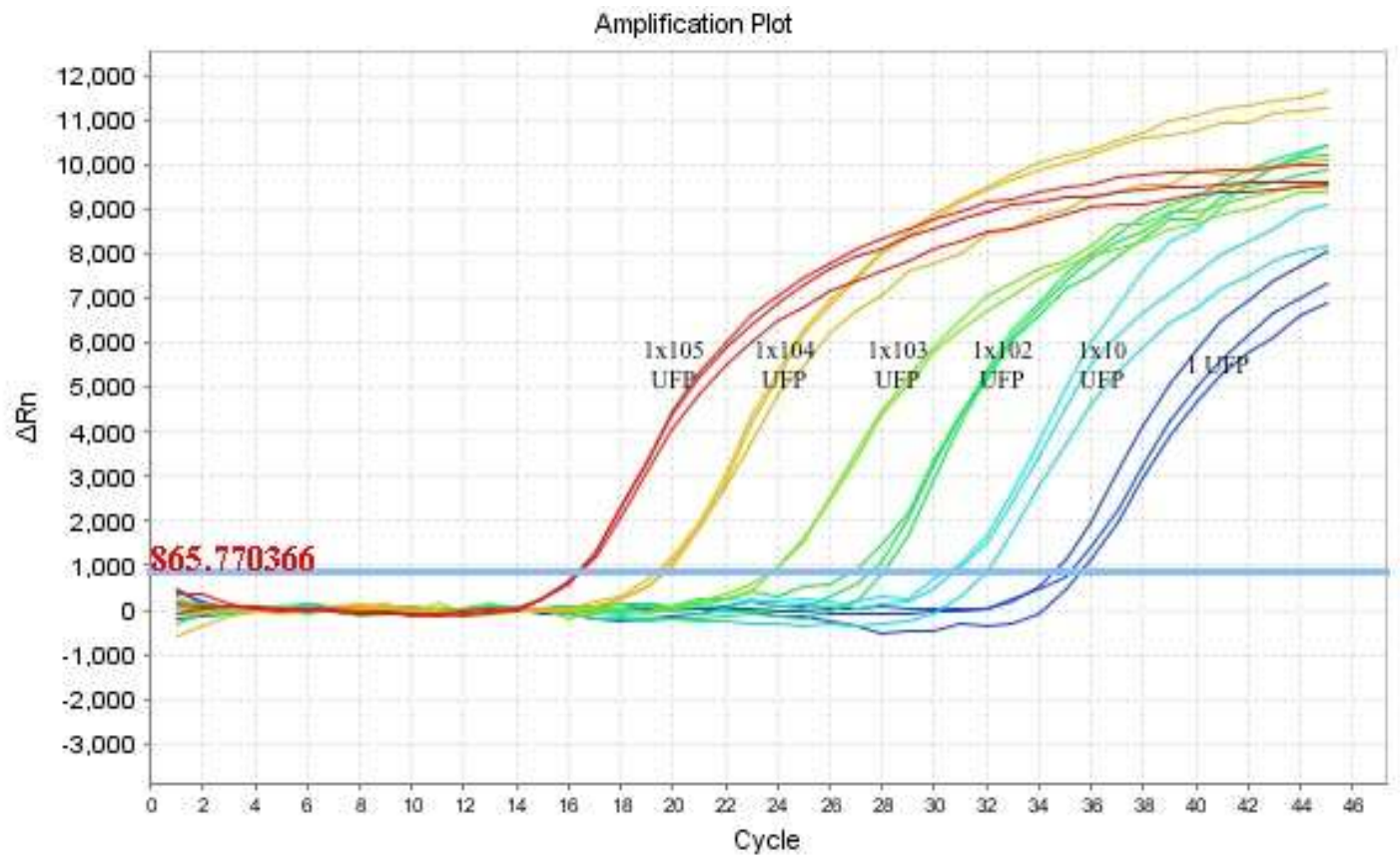

Gráfico 1 - Curva padrão de eficiência para o protocolo de RT-qPCR para o vírus vacinal da Febre Amarela, utilizando-se os primers Flavi all S e Flavi all AS2, com sonda Flavi all 3. Para o cálculo da mesma, foram selecionados 6 pontos com 3 triplicata. Registro de resultado de experimento

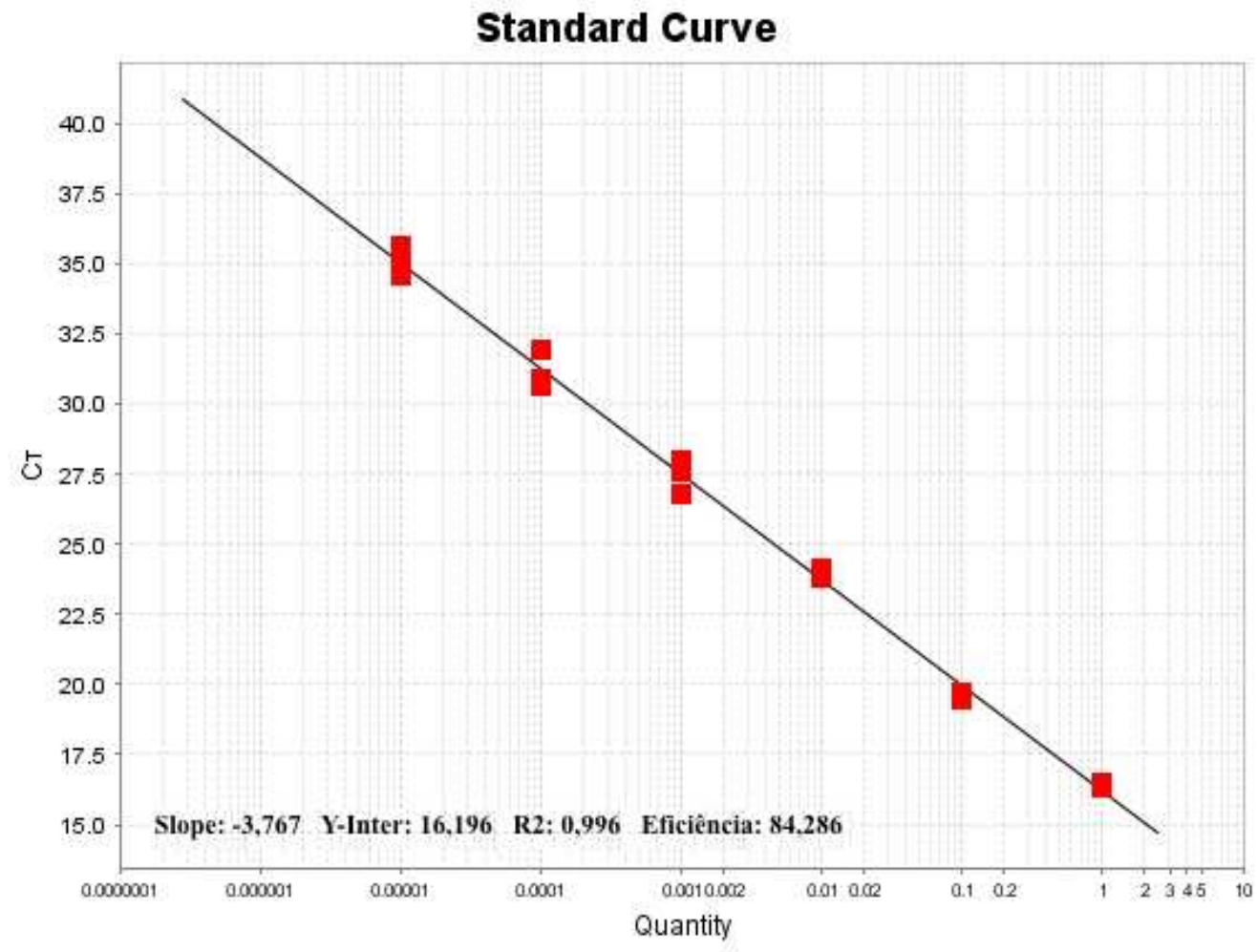


O VILH, cujo título foi de $1,7 \times 10^{4} \mathrm{UFP} / \mathrm{mL}$, teve seu limite máximo de detecção na diluição de $10^{-7}$, que corresponde a 0,01 UFP. A figura 7 mostra as curvas de amplificação obtidas, em duplicata, enquanto que o Gráfico 2 mostra a curva padrão e valores de Slope $(-3,787)$ Y-intercepto $(16,482)$, valor de coeficiente de correlação $\left(R^{2}\right)(98,8 \%)$ e eficiência da reação $(83,7 \%)$ obtidos com uso dos primers Flavi all S e Flavi all AS2, com sonda Flavi all 3.

Figura 7 - Perfil linear da absorbância emitida durante cada ciclo no protocolo da curva de concentração decrescente para o protocolo de RT-qPCR para o vírus llheus, utilizando-se os primers Flavi all S e Flavi all AS2, com sonda Flavi all 3. Estão incluídas 2 repetições para as diluições do vírus, de $10^{-1}$ a $10^{-8}$. Registro de resultado de experimento interpretado pelo software $A B I$ StepOne v2.3.

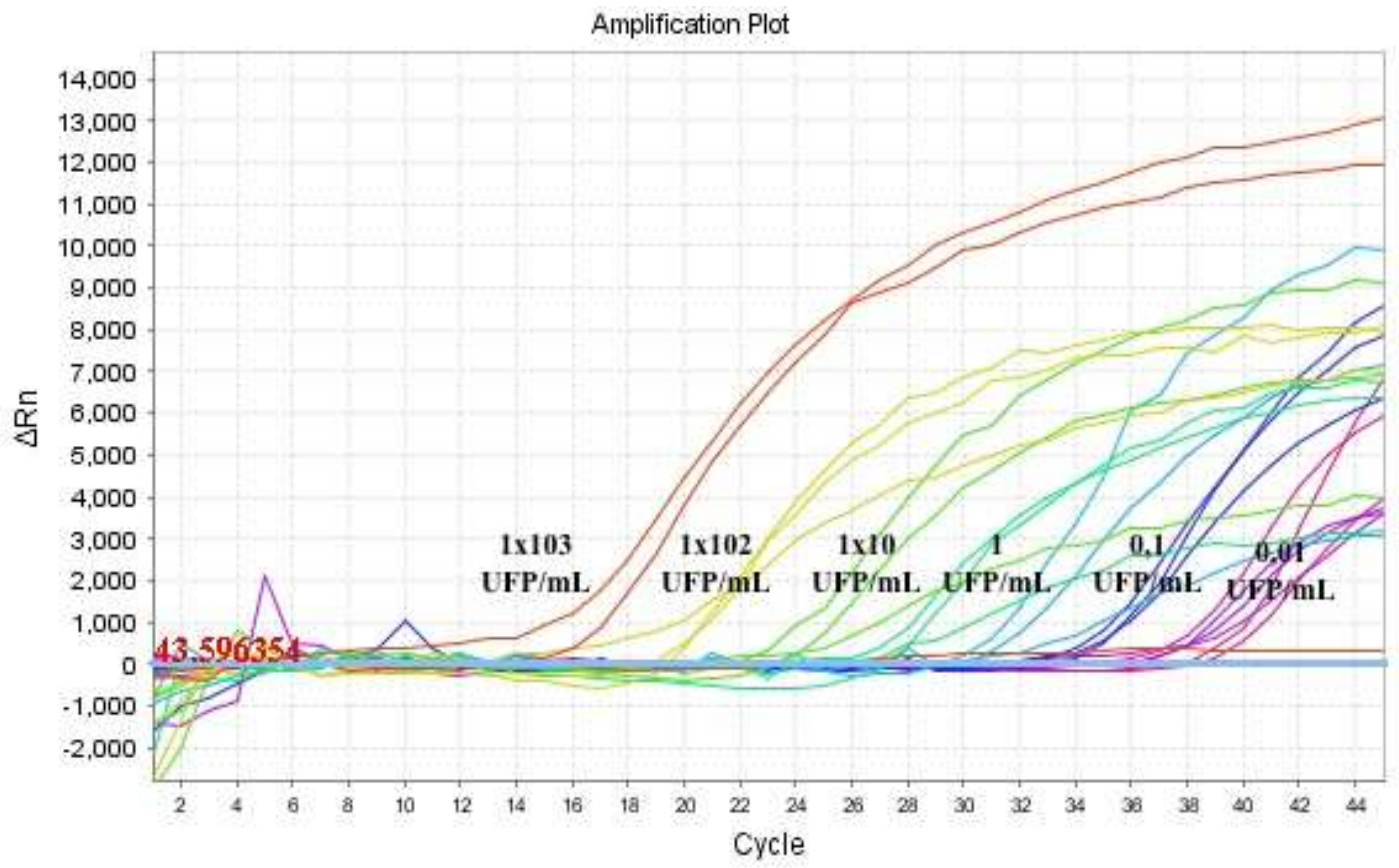


Gráfico 2 - Curva padrão de eficiência para o protocolo de RT-qPCR para o vírus llheus, utilizando-se os primers Flavi all S e Flavi all AS2, com sonda Flavi all 3. Para o cálculo da mesma, foram selecionados 6 pontos com 2 repetições. Registro de resultado de experimento interpretado pelo software ABI StepOne v2.3.

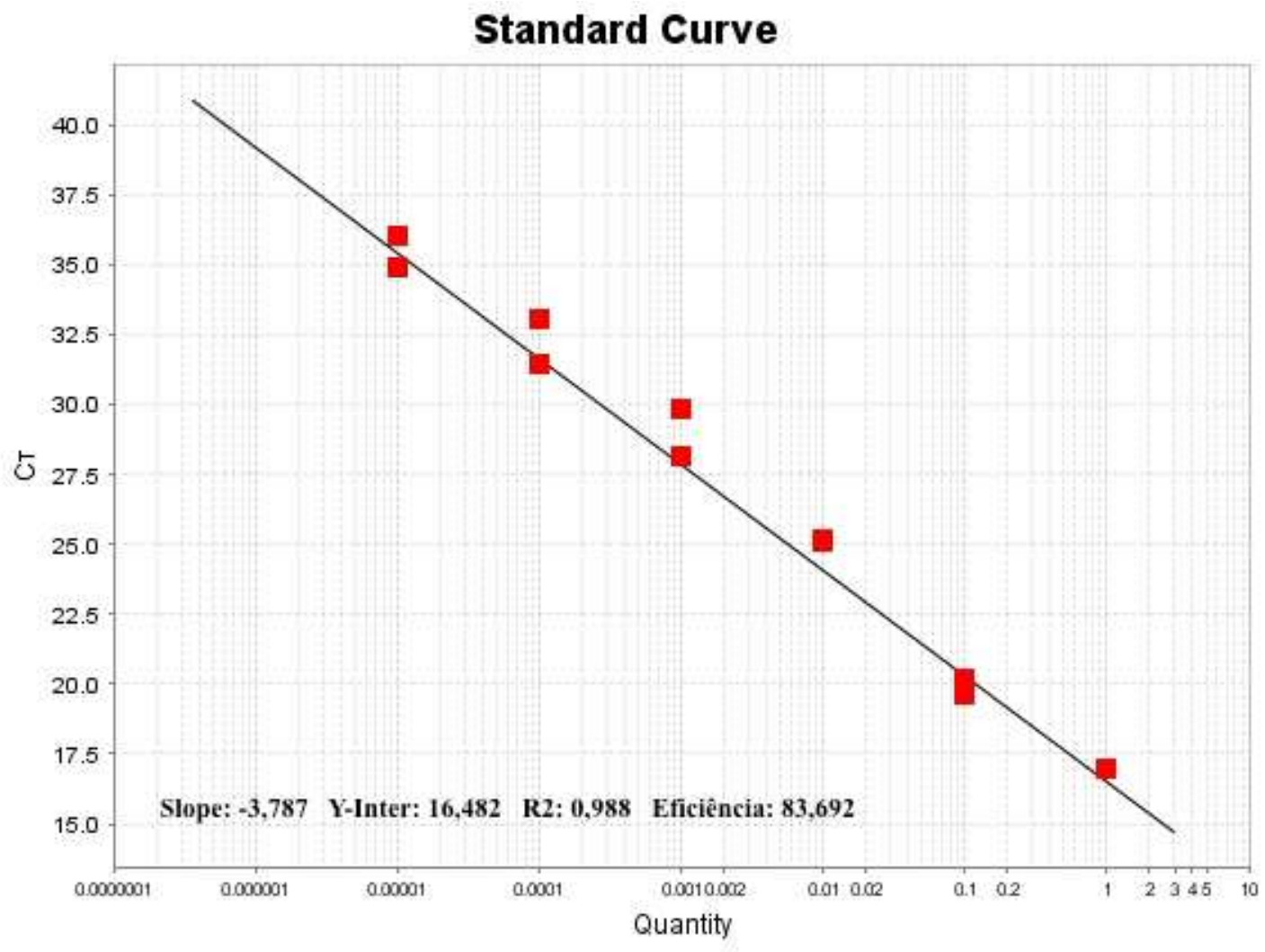

\subsubsection{Vírus da Encefalite de Saint Louis}

O VESL, cujo título foi de $9,4 \times 10^{4} \mathrm{UFP} / \mathrm{mL}$, teve seu limite máximo de detecção na diluição de $10^{-5}$, que corresponde a 0,1 UFP. A figura 8 mostra as curvas de amplificação obtidas, em triplicata, enquanto que o Gráfico 3 mostra a curva padrão e valores de Slope $(-3,973)$ Y-intercepto $(23,459)$, valor de coeficiente de correlação $\left(R^{2}\right)(97,2 \%)$ e eficiência da reação $(78,5 \%)$ obtidos com uso dos primers Flavi all S e Flavi all AS2, com sonda Flavi all 3. 
Figura 8- Perfil linear da absorbância emitida durante cada ciclo no protocolo da curva de concentração decrescente para o protocolo de RT-qPCR para o vírus da Encefalite de Saint Louis, utilizando-se os primers Flavi all S e Flavi all AS2, com sonda Flavi all. Estão incluídas 2 repetições para as diluições do vírus, de 10-1 a 10-8. Registro de resultado de experimento interpretado pelo software ABI StepOne v2.3.

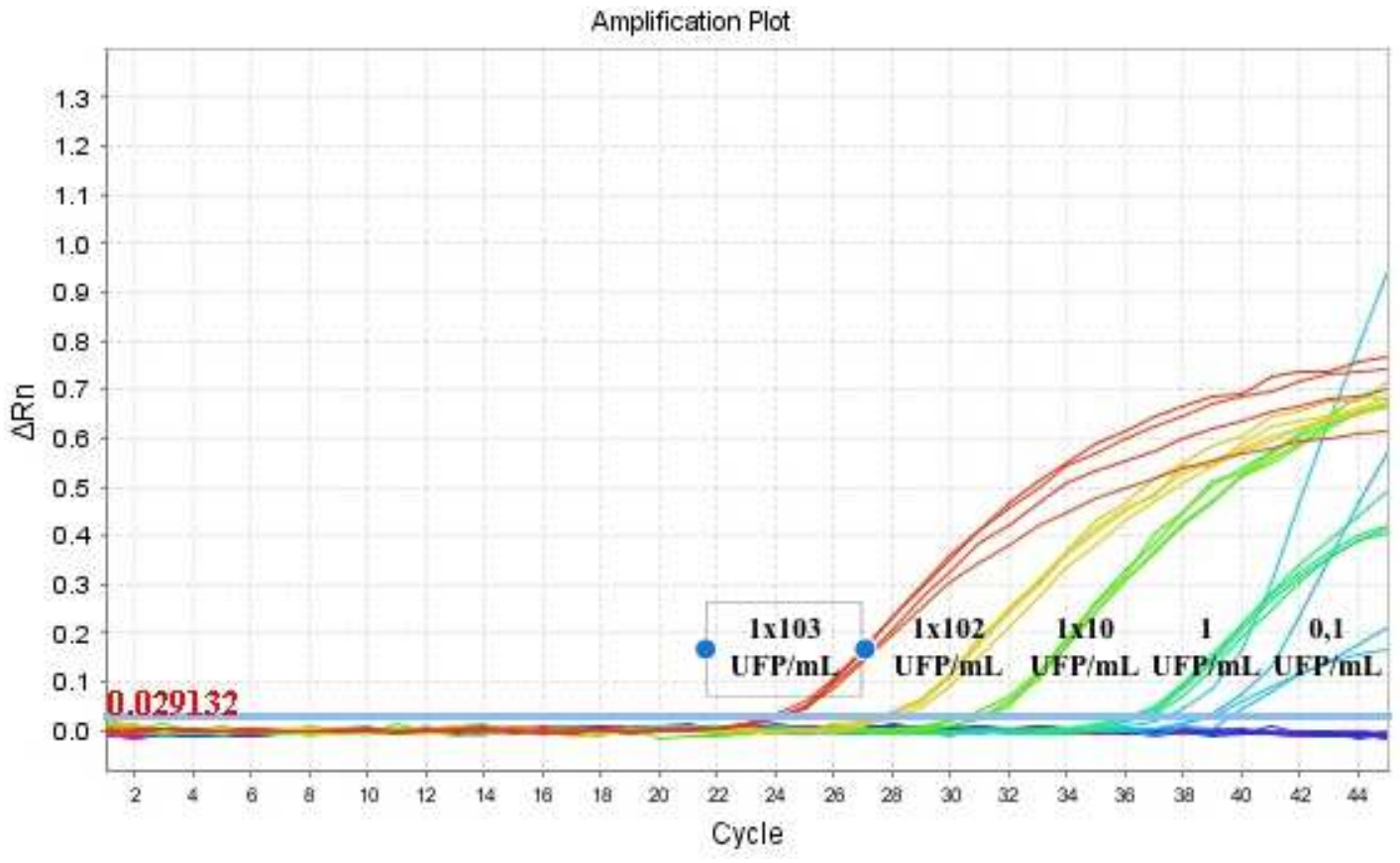


Gráfico 3 - Curva padrão de eficiência para o protocolo de RT-qPCR para o vírus da Encefalite de Saint Louis, utilizando-se os primers Flavi all S e Flavi all AS2, com sonda Flavi all. 3 Para o cálculo da mesma, foram selecionados 5 pontos com 3 repetições. Registro de resultado de experimento interpretado pelo software ABI StepOne v2.3.

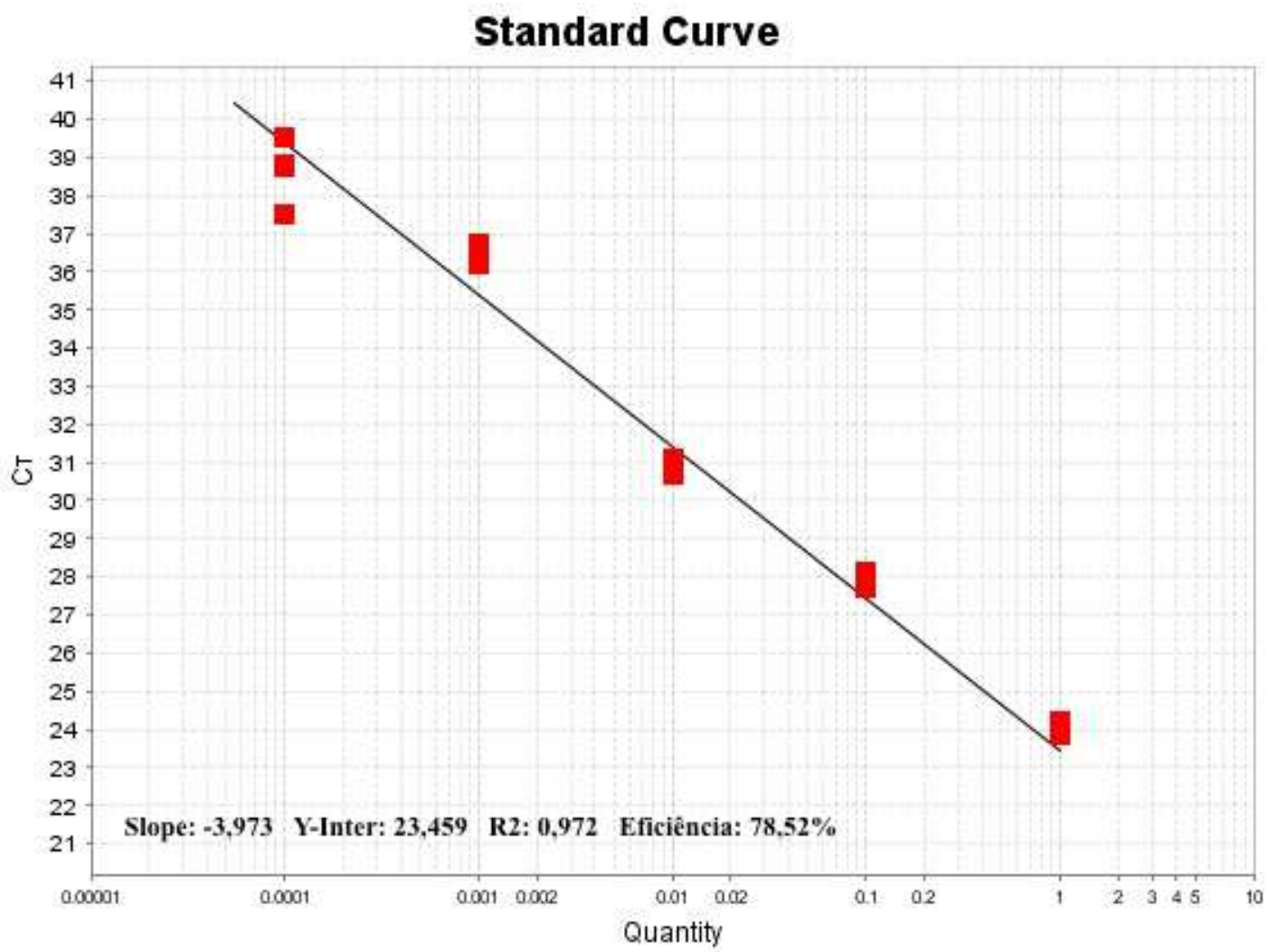

\subsubsection{Vírus Zika}

O VZIK, cujo título foi de $7,5 \times 10^{5} \mathrm{UFP} / \mathrm{mL}$, teve seu limite máximo de detecção na diluição de 10-6, que corresponde a 0,1 UFP. A figura 9 mostra as curvas de amplificação obtidas, em triplicata, enquanto que o Gráfico 4 mostra a curva padrão e valores de Slope $(-3,558)$ Y-intercepto $(20,863)$, valor de coeficiente de correlação (R2) (99,5\%) e eficiência da reação (91\%) obtidos com uso dos primers Flavi all S e Flavi all AS2, com sonda Flavi all 3. 
Figura 9 - Perfil linear da absorbância emitida durante cada ciclo no protocolo da curva de concentração decrescente para o protocolo de RT-qPCR para o vírus Zika, utilizando-se os primers Flavi all S e Flavi all AS2, com sonda Flavi all 3. Estão incluídas 4 repetições para as diluições do vírus, de $10^{-1}$ a $10^{-8}$. Registro de resultado de experimento interpretado pelo software $A B I$ StepOne v2.3.

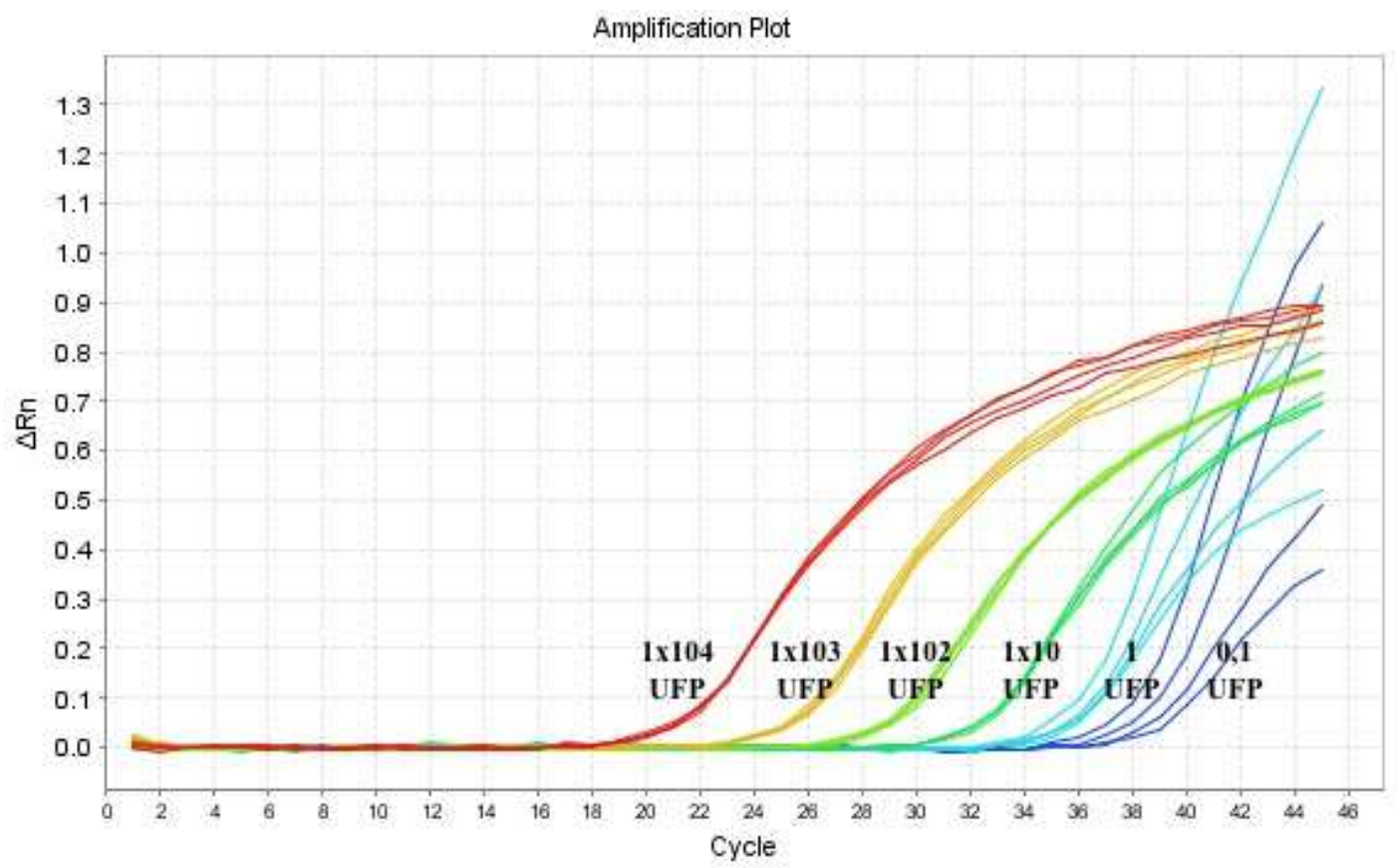


Gráfico 4 - Curva padrão de eficiência para o protocolo de RT-qPCR para o vírus Zika, utilizando-se os primers Flavi all S e Flavi all AS2, com sonda Flavi all 3. Para o cálculo da mesma, foram selecionados 5 pontos com 3 repetições. Registro de resultado de experimento interpretado pelo software ABI StepOne v2.3.

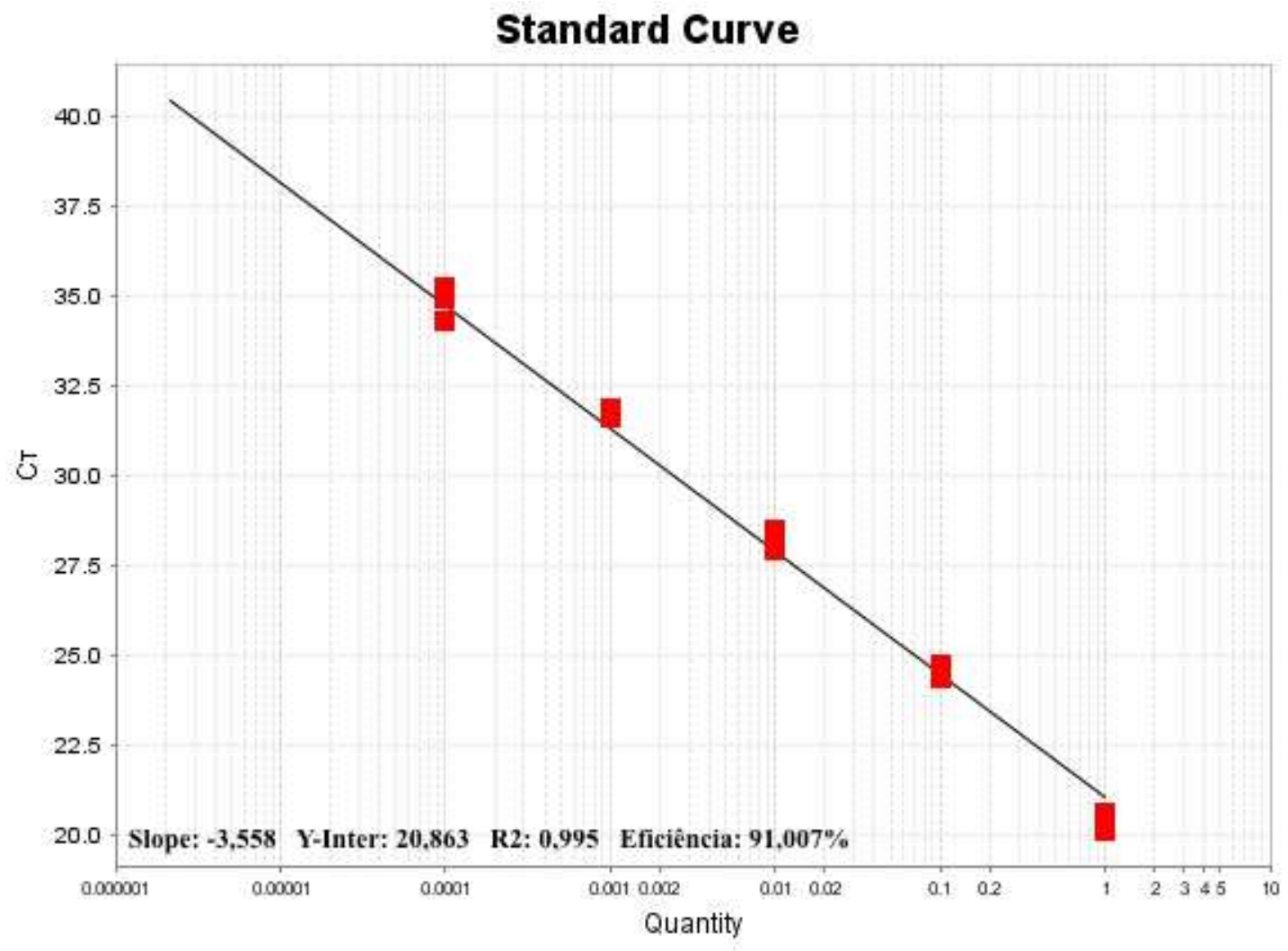

\subsubsection{Vírus Iguape}

O VIGP, cujo título foi de $4,4 \times 10^{8} \mathrm{UFP} / \mathrm{mL}$, teve seu limite máximo de detecção na diluição de $10^{-6}$, que corresponde a 1 UFP. A figura 10 mostra as curvas de amplificação obtidas, em triplicata, enquanto que o Gráfico 5 mostra a curva padrão e valores de Slope $(-3,357)$ Y-intercepto $(21,03)$, valor de coeficiente de correlação $\left(R^{2}\right)(97,2 \%)$ e eficiência da reação $(98,5 \%)$ obtidos com uso dos primers Flavi all S e Flavi all AS2, com sonda Flavi all 3. 
Figura 10 - Perfil linear da absorbância emitida durante cada ciclo no protocolo da curva de concentração decrescente para o protocolo de RT-qPCR para o vírus Iguape, utilizando-se os primers Flavi all S e Flavi all AS2, com sonda Flavi all 3. Estão incluídas 3 repetições para as diluições do vírus, de $10^{-1}$ a $10^{-8}$. Registro de resultado de experimento interpretado pelo software $A B I$ StepOne v2.3.

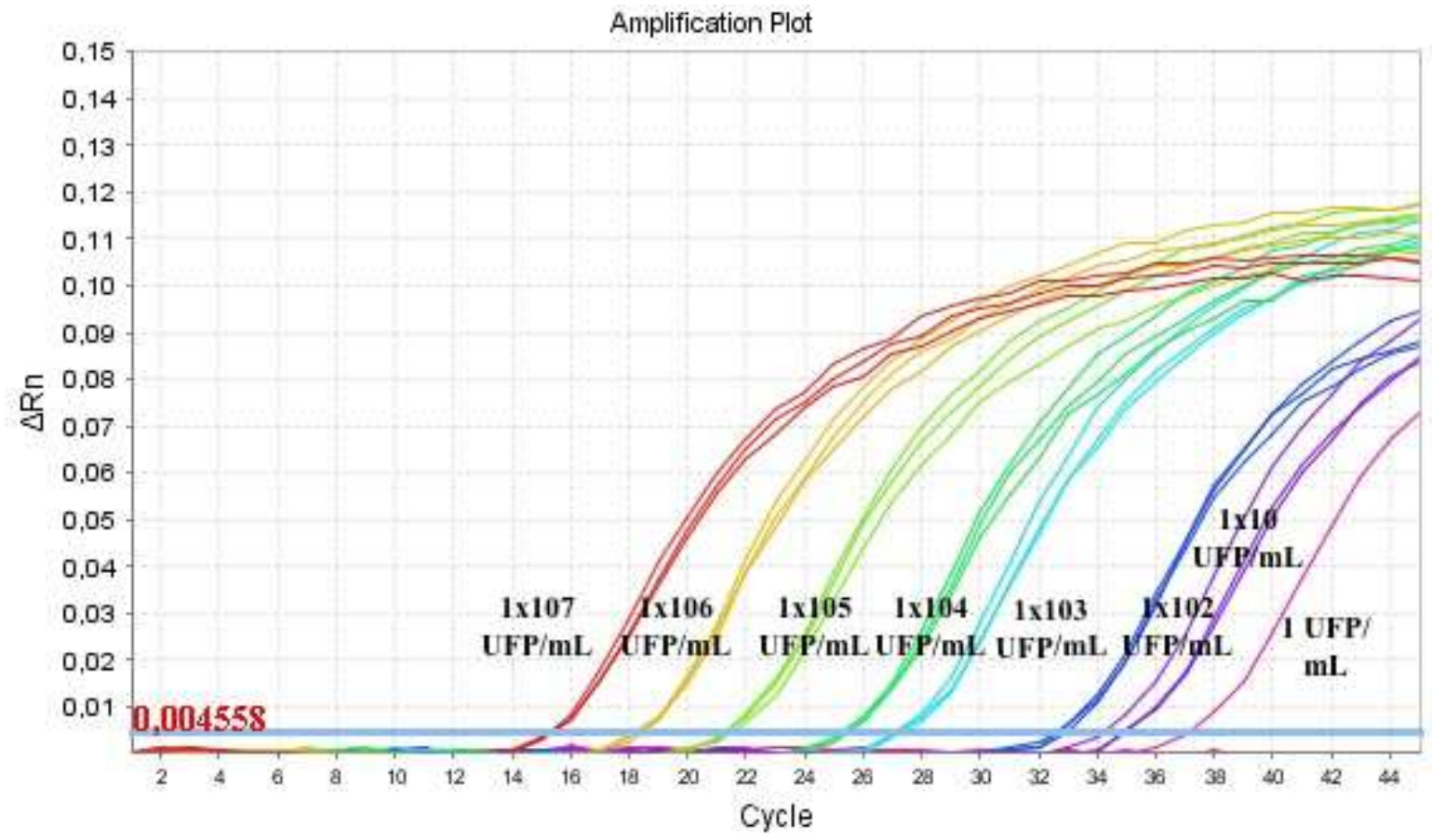


Gráfico 5 - Curva padrão de eficiência para o protocolo de RT-qPCR para o vírus Iguape, utilizandose os primers Flavi all S e Flavi all AS2, com sonda Flavi all 3. Para o cálculo da mesma, foram selecionados 5 pontos com 3 repetições. Registro de resultado de experimento interpretado pelo software ABI StepOne v2.3.

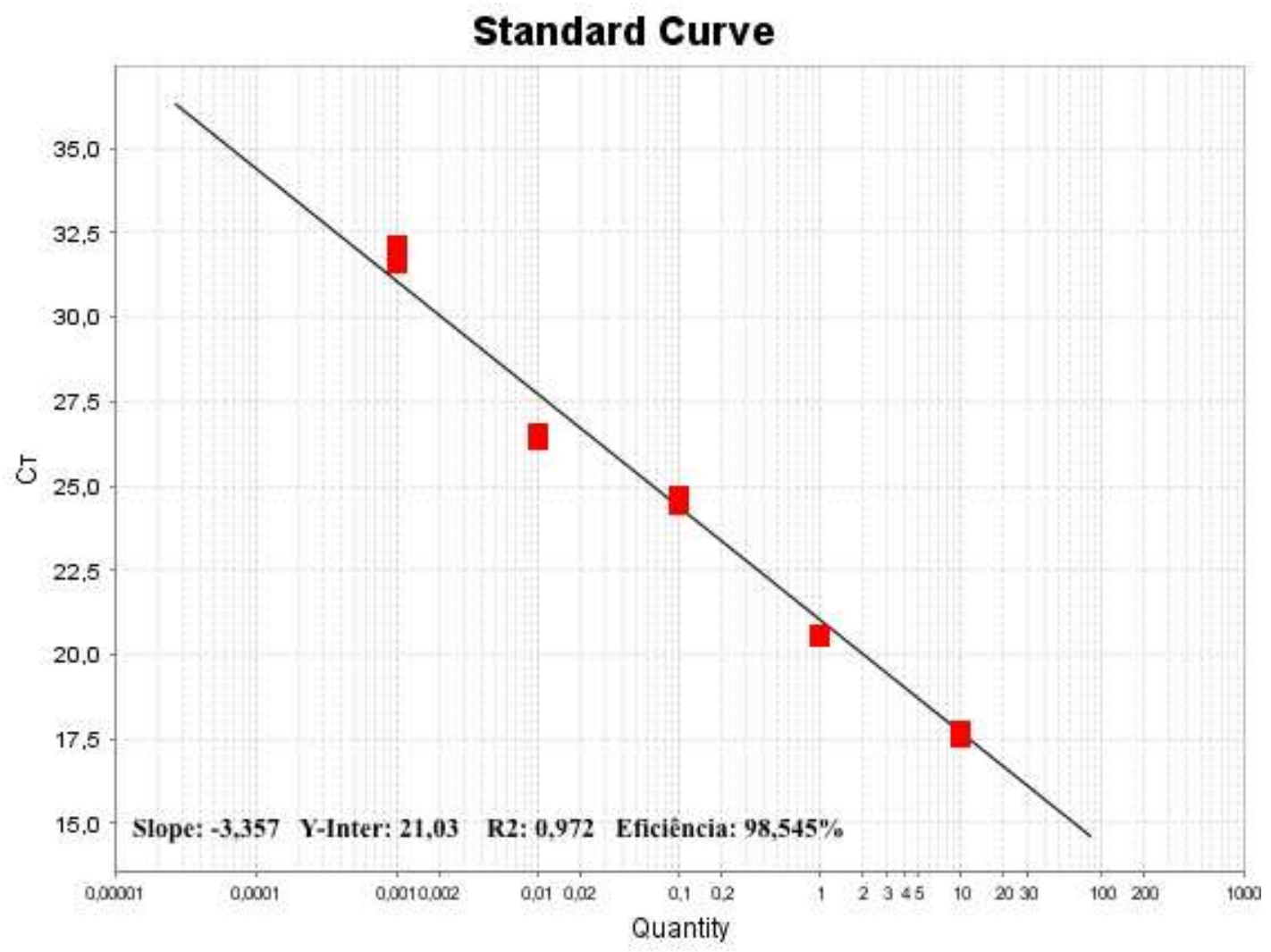

\subsubsection{Vírus Cacipacore}

O VCPC, cujo título foi de $3 \times 10^{4} \mathrm{UFP} / \mathrm{mL}$, teve seu limite máximo de detecção na diluição de $10^{-7}$, que corresponde a 0,1 UFP. A figura 11 mostra as curvas de amplificação obtidas, em triplicata, enquanto que o Gráfico 6 mostra a curva padrão e valores de Slope $(-3,581)$ Y-intercepto $(18,056)$, valor de coeficiente de correlação $\left(R^{2}\right)(97,4 \%)$ e eficiência da reação $(90,2 \%)$ obtidos com uso dos primers Flavi all S e Flavi all AS2, com sonda Flavi all 3. 
Figura 11- Perfil linear da absorbância emitida durante cada ciclo no protocolo da curva de concentração decrescente para o protocolo de RT-qPCR para o vírus Cacipacore, utilizando-se os primers Flavi all S e Flavi all AS2, com sonda Flavi all 3. Estão incluídas 3 repetições para as diluições do vírus, de $10^{-1}$ a $10^{-8}$. Registro de resultado de experimento interpretado pelo software $A B I$ StepOne v2.3.

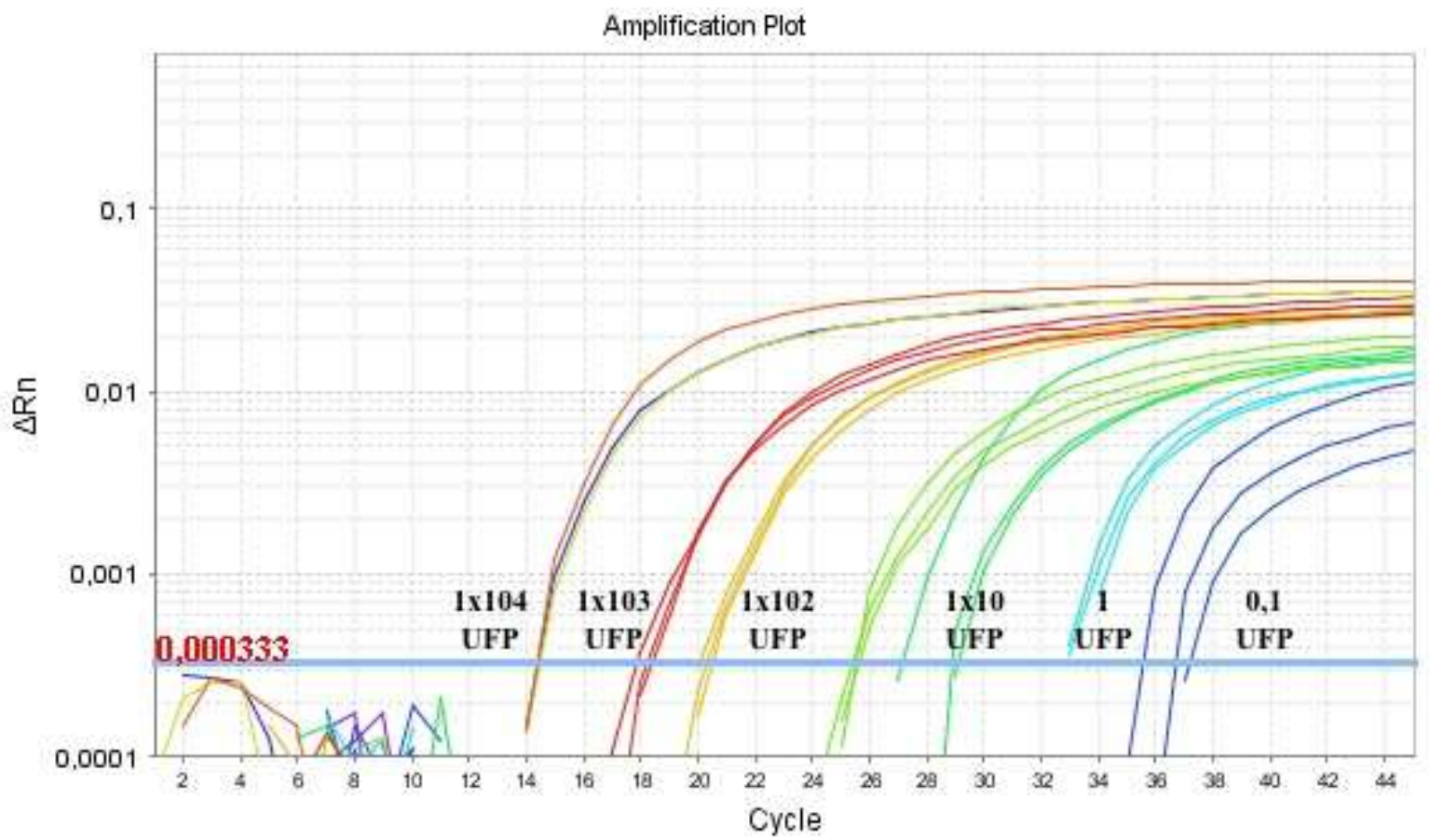


Gráfico 6 - Curva padrão de eficiência para o protocolo de RT-qPCR para o vírus Cacipacore, utilizando-se os primers Flavi all S e Flavi all AS2, com sonda Flavi all 3. Para o cálculo da mesma, foram selecionados 6 pontos com 3 repetições. Registro de resultado de experimento interpretado pelo software ABI StepOne v2.3.

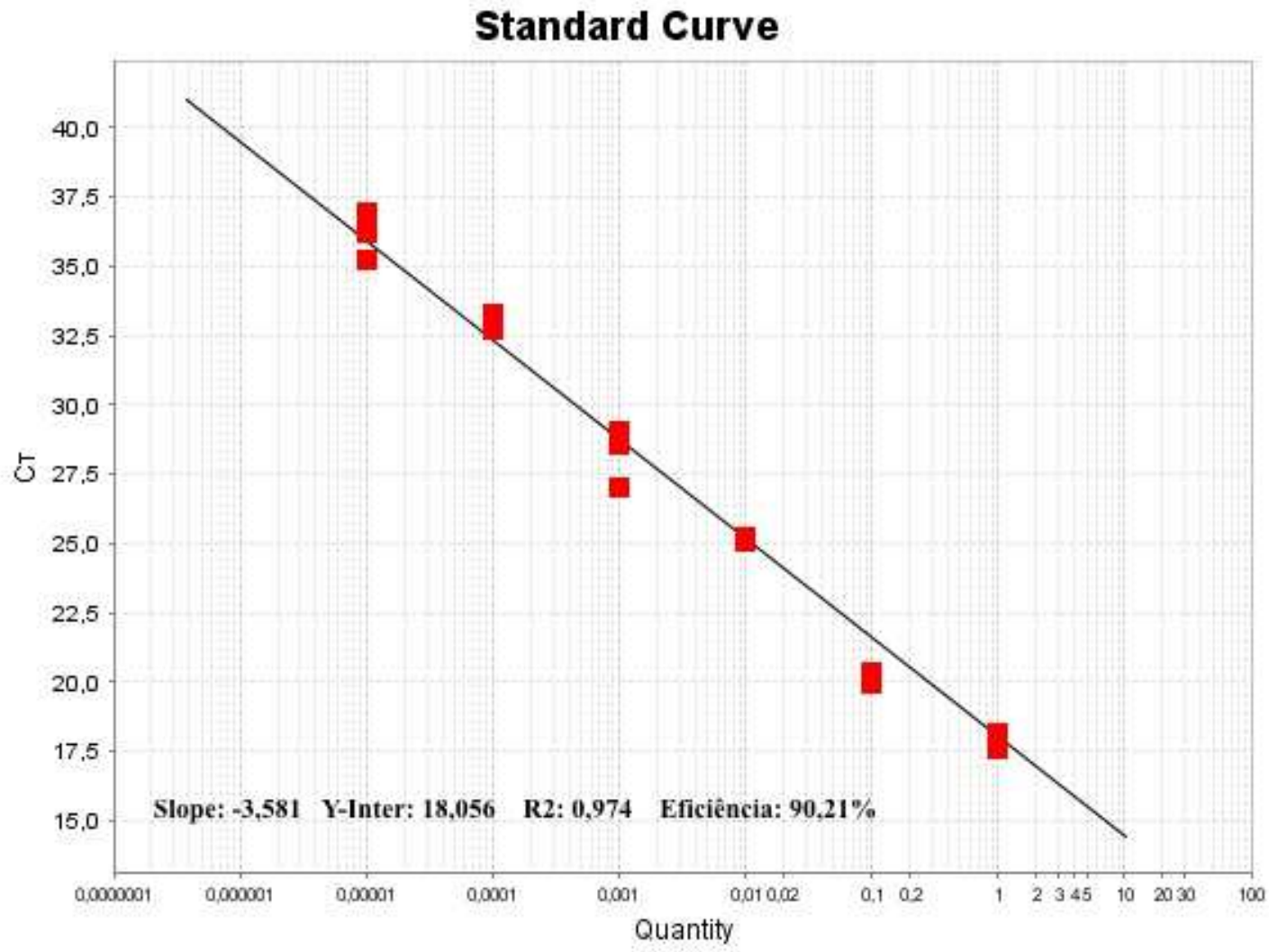

\subsubsection{Vírus Bussuquara}

O VBSQ, cujo título foi de $1 \times 10^{3,6} \mathrm{TCID} 50 / 100 / \mu \mathrm{L}$, teve seu limite máximo de

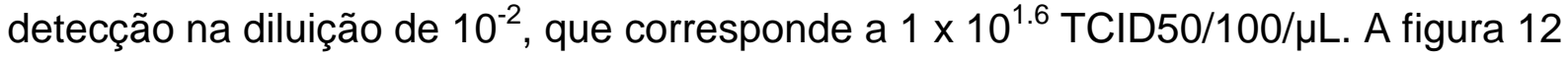
mostra as curvas de amplificação obtidas, em triplicata, obtidos com uso dos primers Flavi all S e Flavi all AS2, com sonda Flavi all 3. A curva de eficiência não pôde ser realizada para este vírus, uma vez que não foi possível selecionar pelo menos cinco pontos para sua elaboração. 
Figura 12 - Perfil linear da absorbância emitida durante cada ciclo no protocolo da curva de concentração decrescente para o protocolo de RT-qPCR para o vírus Bussuquara, utilizando-se os primers Flavi all $S$ e Flavi all AS2, com sonda Flavi all 3. Estão incluídas 3 repetições para as diluições do vírus, de $10^{-1}$ a $10^{-8}$. Registro de resultado de experimento interpretado pelo software $A B I$ StepOne v2.3.

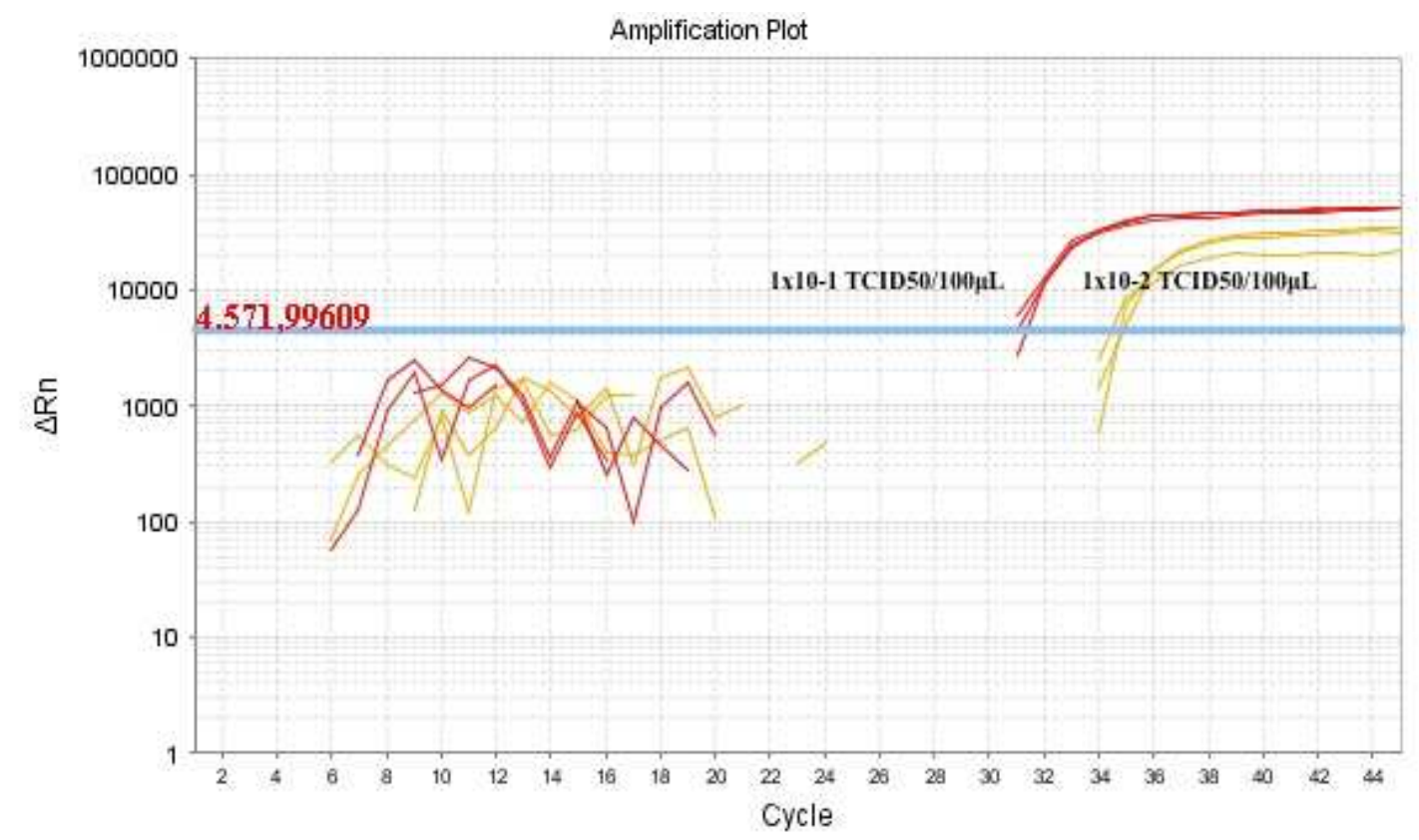

\subsection{EFICIÊNCIA E LIMITES DE DETECÇÃO}

A Tabela 8 mostra as médias dos valores de Ct obtidos para cada diluição dos vírus utilizados, bem como a eficiência da reação de RT-qPCR calculada pelo software do aparelho ABI SteOne v2.3, com exceção do vírus Bussuquara, cuja curva padrão não foi obtida graças a baixa sensibilidade da técnica. 
Tabela 8 - Médias dos valores de Ct obtidos através de reação de RT-qPCR utilizando-se os primers Flavi all S e Flavi all AS2, com sonda Flavi all 3 para cada dilução dos flavivírus usados no presente estudo e respectivos valores da eficiência de cada reação.

\begin{tabular}{cccccccccc}
\hline & $\mathbf{1 0}^{-\mathbf{- 1}}$ & $\mathbf{1 0 ^ { - 2 }}$ & $\mathbf{1 0 ^ { - 3 }}$ & $\mathbf{1 0}^{-4}$ & $\mathbf{1 0}^{-5}$ & $\mathbf{1 0}^{-\mathbf{6}}$ & $\mathbf{1 0}^{-\mathbf{7}}$ & $\mathbf{1 0}^{-\mathbf{8}}$ & Eficiência \\
\hline VFA 17D & 16 & 20 & 24 & 27 & 31,3 & 35,3 & 40,4 & 0 & $84,3 \%$ \\
VCAC & 18 & 20 & 25 & 29 & 33 & 35,6 & 40 & 40,5 & $90,21 \%$ \\
VBSQ & 31 & 34,5 & 0 & 0 & 0 & 0 & 0 & 0 & - \\
VIGP & 15 & 18 & 21 & 24,6 & 27 & 32 & 33,6 & 36 & $98,5 \%$ \\
VILH & 17 & 20 & 25 & 28,6 & 32,6 & 36 & 39 & 39,8 & $83,7 \%$ \\
VESL & 24 & 28 & 31,25 & 37 & 39 & 0 & 0 & 0 & $78,5 \%$ \\
ZIKV & 20 & 24 & 28 & 31,75 & 35,25 & 37,75 & 40,5 & 0 & $91,0 \%$ \\
\hline
\end{tabular}

Os resultados aqui obtidos mostram uma boa sensibilidade para os flavivírus de ocorrência no Brasil, que variaram de 0,01 UFP a 1 UFP, com exceção do VBSQ, uma vez que a mesma não pôde ser calculada devido à ausência de pelo menos cinco positivos para seu cálculo. No entanto, foi possível demonstrar que, mesmo com menor sensibilidade, este vírus tem sua detecção positiva pela técnica, cujo

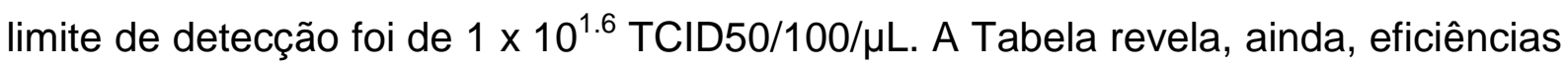
que variaram de $78,5 \%$ a $98,5 \%$, dependendo do vírus.

\subsection{COMPARAÇÃO DA DETECÇÃO COM OUTRAS METODOLOGIAS}

Os limites de detecção de cada diluição dos vírus padrões foram comparados tanto com as RT-qPCR específicas utilizando-se os oligoiniciadores específicos já descritos para VFA, VESL e VZIK (DOMINGO et al., 2012; DYER; CHISENHALL; MORES, 2007; LANCIOTTI et al., 2008), e também comparados com isolamento celular após uma passagem em células C6/36, seguido de IFI, utilizando-se anticorpos anti-flavivírus policlonais. Todos os valores obtidos estão descritos na Tabela 9. Além disso, os valores de Ct das RT-qPCR específicas obtidos estão demonstrados na Tabela 10. Os demais vírus não possuem protocolos específicos 
descritos em literatura. Consideram-se positivos os resultados de Ct até 39,7, com todas as repetições positivas.

Tabela 9 - Comparação dos resultados dos limites de detecção para cada um dos flavivírus utilizados no presente estudo em diferentes técnicas, demonstrados em unidades formadoras de placa por $\mathrm{mL}$ ou TCID50.

\begin{tabular}{cccccccc}
\hline & BUSQ & CACV & IGPV & ILHV & SLEV & YFV & ZIKV \\
\hline $\begin{array}{c}\text { RT-qPCR } \\
\text { pan Flavi }\end{array}$ & $1 \times 10^{1,6}$ & 0,1 & 1 & 0,01 & 0,1 & 1 & 0,1 \\
RT-qPCR & NR & NR & NR & NR & 0,01 & 0,1 & 0,1 \\
específico & & & & & & & \\
IFI & $1 \times 10^{0,6}$ & 1 & 1000 & 100 & 1 & 100 & 1 \\
\hline Legenda: NR: não realizado & & & &
\end{tabular}

Legenda: NR: não realizado

Tabela 10 - Valores de Ct obtidos através de reação de RT-qPCR utilizando-se os pares de iniciadores descritos por DOMINGO et al., 2012 (VFA); DYER; CHISENHALL; MORES, 2007 (VESL) e LANCIOTTI et al., 2008 (VZIK).

\begin{tabular}{cccc}
\hline Diluição & VFA & VESL & VZIK \\
\hline $10^{-1}$ & NR & NR & 21 \\
$10^{-2}$ & 19 & NR & 26 \\
$10^{-3}$ & 22 & 24 & 28 \\
$10^{-4}$ & 26 & 29 & 32 \\
$10^{-5}$ & 29 & 32 & 35 \\
$10^{-6}$ & 33 & 38 & 38 \\
$10^{-7}$ & 37 & 0 & 41 \\
$10^{-8}$ & 0 & 0 & 0 \\
\hline
\end{tabular}

Legenda: NR: não realizado

\subsection{VÍRUS IDENTIFICADOS}

Camundongos neonatos com suspeita de isolamento viral provenientes de inoculação de mosquitos capturados previamente, armazenados em freezer $-70^{\circ} \mathrm{C}$, tiveram os cérebros macerados e testados com o presente protocolo. Os resultados positivos para gênero Flavivirus obtidos após a reação de sequenciamento de nucleotídeos e análise no BLAST estão demonstrados na Tabela 11. 
Tabela 11 - Flavivírus identificados no presente estudo após reação de RT-qPCR seguida de sequenciamento utilizando-se os primers Flavi all S e Flavi all AS 2 e sonda Flavi all 3, com análise de nucleotídeos utilizando-se a ferramenta BLAST.

\begin{tabular}{ccccccc}
\hline Amostra & Local & Data & Espécie & Resultado & $\begin{array}{c}E- \\
\text { value }\end{array}$ & ID \\
& & & & & & \\
\hline SPAR158533 & Juquitiba & $01 / 11 / 94$ & Cq. juxtamansonia & VILH & $7 \mathrm{e}-100$ & $100 \%$ \\
SPAR158482 & Juquitiba & $01 / 07 / 94$ & An. cruzii & VIGP & $1 \mathrm{e}-107$ & $99 \%$ \\
SPAR158495 & Juquitiba & $01 / 07 / 94$ & An. cruzii & VIGP & $1 \mathrm{e}-123$ & $98 \%$ \\
SPAR158517 & Juquitiba & $30 / 10 / 94$ & An. triannulatus & VILH & $4 \mathrm{e}-107$ & $99 \%$ \\
SPAR158470 & Juquitiba & $01 / 07 / 94$ & An. cruzii & VIGP & $1 \mathrm{e}-123$ & $98 \%$ \\
SPAR158584 & Juquitiba & $27 / 10 / 94$ & Cx.spp & VILH & $7 \mathrm{e}-100$ & $100 \%$ \\
03/17829 & Campinas & $02 / 04 / 15$ & Humana & VZIK & $5 \mathrm{e}-112$ & $99 \%$ \\
\hline
\end{tabular}

Legenda: E-value: valor de expectativa; ID: identidade

O presente descreve a ocorrência dos vírus llheus e Iguape em diferentes espécies de Culicídeos, capturados no município de Juquitiba no ano de 1994, sendo o VILH isolado de pools de mosquitos Anopheles triannulatus, Culex spp. e Coquillettidia juxtamansonia, e o VIGP de mosquitos Anopheles cruzii. Foi possível identificar, ainda, o primeiro isolado do vírus Zika no Brasil, obtido a partir de um doador de sangue sintomático com suspeita de dengue, visando a confirmação de seu diagnóstico após isolamento positivo em células C6/36 e resultados negativos para o vírus Dengue sorotipos 1, 2, 3 e 4.

Ainda, a partir de meados de 2016, foram realizadas pesquisas entomológicas para o vírus da Febre Amarela devido ao surto no estado de São Paulo, sendo enviados pela SUCEN cerca de 800 pools de mosquitos de gêneros variados coletados em diversos, para isolamento viral. Dois deles, de Aedes scapularis e Aedes terrens, coletados em Guapiaçu, tiveram isolamento confirmado para flavivírus após reação de IFI com anticorpos policlonais, sendo no entanto negativos quando usados anticorpos monoclonais de dengue e febre amarela. Visando, portanto, a identificação desses isolados, o presente protocolo foi utilizado, com resultados positivos com valores de $\mathrm{Ct}$ de 13 e 18 . Os fragmentos de 247 e 240 pares de base gerados por sequenciamento foram alinhados no programa BioEdit, com $100 \%$ de homologia entre eles. Quando a sequência de nucleotídeos foi testada com a ferramenta $B L A S T$, as identidades encontradas variaram de $81 \%$ a $83 \%$ com 
isolados do vírus do Oeste do Nilo sul-africanos pertencentes à linhagem 2 (números de acesso no GenBank EF429199 e EF429198, JN393308, KY523178, KM052152, DQ318020), com 70\% e 65\% de cobertura para o SPARFLAVI1 e SPARFLAV2, respectivamente. Quando analisada a cadeia de aminoácidos, obtiveram-se similaridades de $91 \%$ com 7 amostras do vírus Long Pine Key (números de acesso no GenBank ATN29918, ATN29919, ATN29916, ATN29921, ATN29917 e ATN29915), um flavivírus específico de mosquitos, com $94 \%$ de cobertura. A reação de RT-qPCR específica para o vírus do Oeste do Nilo foi negativa usando-se protocolo descrito por Lanciotti e colaboradores (2000), e os vírus não apresentaram efeito citopático quando inoculados em células Vero. Posteriormente, a reações de sequenciamento com uso de iniciadores descritos por Kuno e colaboradores (1998a) resultaram em um fragmento de 1576 pb da NS5, que foram idênticas para os dois isolados, que mostrou similaridades entre 75 e $77 \%$ com diferentes isolados do vírus Long Pine Key por meio de análise no BLAST. O alinhamento deste possível novo vírus está demonstrada na Figura 13. 
Figura 13 - Alinhamento de fragmento 1360 pares de base da NS5 gerado dos isolados SPARFlavi01 e SPARFlavi02 com demais vírus específicos de insetos recuperados do GenBanK.

IcI|KY290256.1_Long Pine Key V Icl|KY290255.1 Long Pine Key v Icl|KY290254.1_Long Pine Key v Icl|KY290253.1_Long Pine Key Icl|KY290251.1 Long Pine Key v Icl|KY290249.1_Long Pine Key v IcI|KY290250.1_Long Pine Key v SPARFlavi01

SPARFlavi02

KC181923.1 Aedes flavivirus st NC_024017.1 Nhumirim virus HQ634598.1 Culex flavivirus HQ634594.1 Culex flavivirus NC_027819.1 Mercadeo virus KP688058.1 Mercadeo virus

IcI|KY290256.1_Long Pine Key V Icl|KY290255.1 Long Pine Key v Icl|KY290254.1_Long Pine Key v Ic||KY290253.1_Long Pine Key IcI|KY290251.1_Long Pine Key v Icl|KY290249.1_Long Pine Key v IcI|KY290250.1_Long Pine Key v SPARFlavi01

SPARFlavi02

KC181923.1 Aedes flavivirus st NC_024017.1 Nhumirim virus HQ634598.1 Culex flavivirus HQ634594.1 Culex flavivirus NC 027819.1 Mercadeo virus KP688058.1 Mercadeo virus

Icl|KY290256.1_Long Pine Key V Icl|KY290255.1 Long Pine Key v Icl|KY290254.1 Long Pine Key v IcI|KY290253.1_Long Pine Key Icl|KY290251.1_Long Pine Key v Icl|KY290249.1_Long Pine Key v Icl|KY290250.1_Long Pine Key v SPARFlavi01

SPARFlavi02

KC181923.1 Aedes flavivirus st NC 024017.1 Nhumirim virus HQ634598.1 Culex flavivirus HQ634594.1 Culex flavivirus NC 027819.1 Mercadeo virus KP688058.1 Mercadeo virus

IcI|KY290256.1_Long Pine Key V IcI|KY290255.1 Long Pine Key v Icl|KY290254.1_Long Pine Key v Icl|KY290253.1 Long Pine Key IcI|KY290251.1_Long Pine Key v IcI|KY290249.1_Long Pine Key v Icl|KY290250.1_Long Pine Key v SPARFlavi01 SPARFlavi02

KC181923.1 Aedes flavivirus st NC 024017.1 Nhumirim virus HQ634598.1 Culex flavivirus HQ634594.1 Culex flavivirus NC_027819.1 Mercadeo virus KP688058.1 Mercadeo virus

IcI|KY290256.1_Long Pine Key V Icl|KY290255.1 Long Pine Key v IcI|KY290254.1_Long Pine Key v IcI|KY290253.1_Long Pine Key Icl|KY290251.1_Long Pine Key v
AAACG TGA A A A A A G AGC TC TGAG T TGG CAAGG C CAAAGGCAGCCGGGC

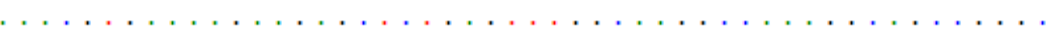

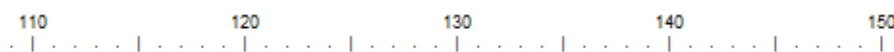

GATTCCTGAACGAAGATCACTGGTTGAG TCGCGAGAACAGCGGAGGAGGA

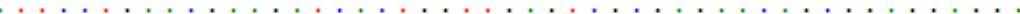

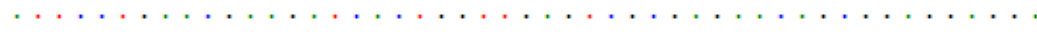
$\ldots$. . . . . . . . . . . . . . . . .

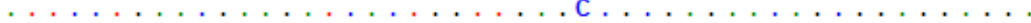
$\ldots \mathrm{T} \ldots \mathrm{T} \ldots \mathrm{C} \ldots \mathrm{C} \mathrm{C} \mathrm{G} \ldots \mathrm{A} \ldots \mathrm{T} \ldots \ldots$

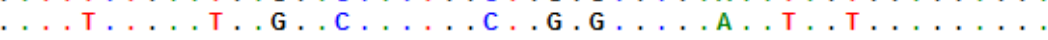

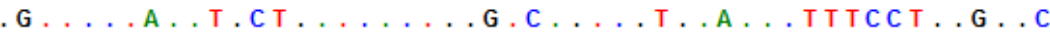
$\ldots T \mathrm{~T} \ldots \mathrm{T} \ldots \mathrm{G} \ldots \mathrm{C} \ldots \mathrm{C} \ldots \mathrm{A} \ldots \mathrm{G} \ldots \mathrm{A} \ldots \mathrm{A} \ldots \mathrm{T} \ldots \mathrm{CAT} \ldots \mathrm{C}$...

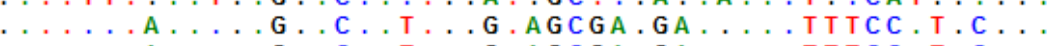

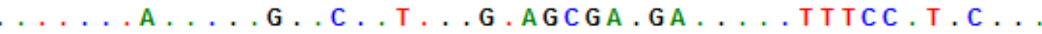

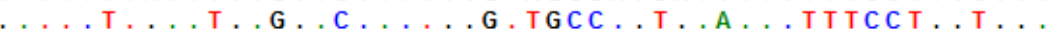

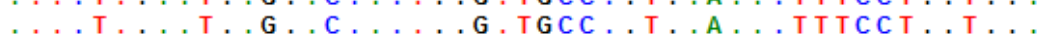

$210 \quad 220 \quad 230 \quad 250$

AAAGAAGGAAGGAGGAAATT TCTATGCTGATGAC ACAGCTGGGTGGGAC

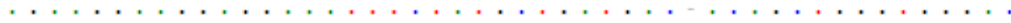

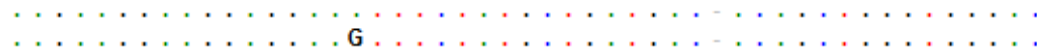

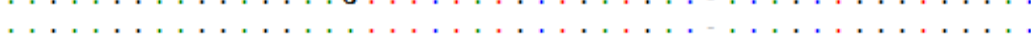
$\mathrm{T} \ldots \mathrm{A} \ldots \mathrm{A} \ldots \mathrm{C} \mathrm{T} \mathrm{C} \ldots \mathrm{C} \mathrm{C} \mathrm{C} \mathrm{C} \ldots$

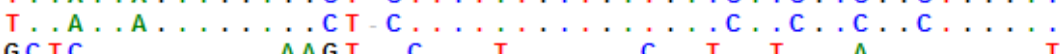

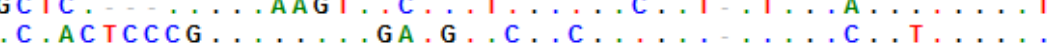

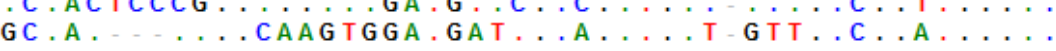

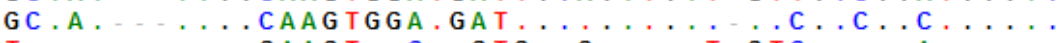

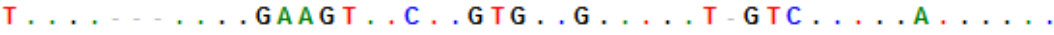

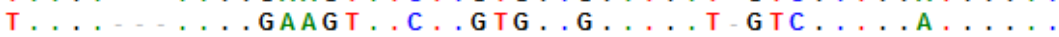

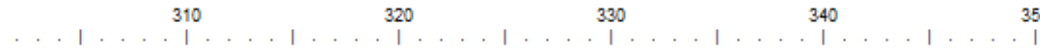
GATGAAAGG TGATCACAAGAAACTCACCCAA $\sim$ GCCATCATGGAGC

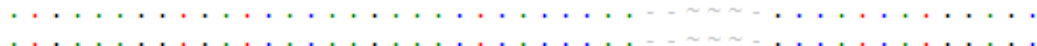
$\ldots \ldots \ldots \ldots \ldots \ldots \ldots \ldots \ldots \ldots \ldots \ldots \ldots \ldots \ldots \ldots \ldots \ldots \ldots \ldots \ldots$

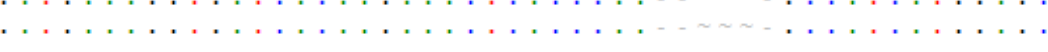

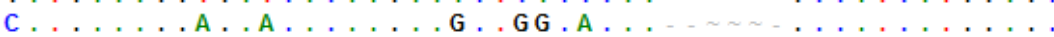

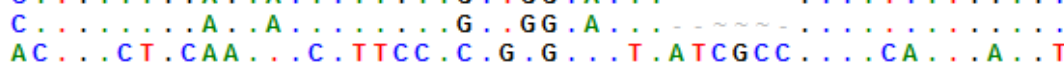

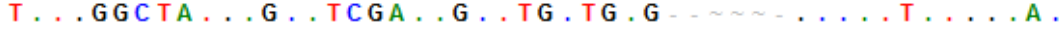
C CAAGTGAC...C.C.T.CC.CGCACAGTTGATACGT.TTG . G T. CA. . CCAAGTGAC...C.C.T.CC.CGCACAGTTGATACGT.TTG.GT.CA.T

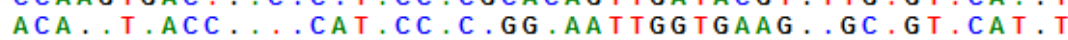
$A C A \ldots T, A C C \ldots C A T, C C, C, G G, A A T T G G T G A A G \ldots G C, G T, C A T \cdot T$

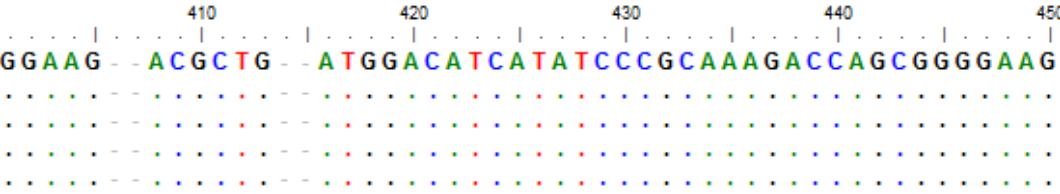


Icl|KY290249.1 Long Pine Key IcI|KY290250.1_Long Pine Key v SPARFlavi01

SPARFlavi02

KC181923.1 Aedes flavivirus st NC_024017.1 Nhumirim virus HQ634598.1 Culex flavivirus HQ634594.1 Culex flavivirus NC_027819.1 Mercadeo virus KP688058.1 Mercadeo virus

Icl|KY290256.1_Long Pine Key v
Ic||KY290255.1 Long Pine Key v
Icl|KY290254.1_Long Pine Key v
Icl|KY290253.1_Long Pine Key
Icl|KY290251.1_Long Pine Key v
Icl|KY290249.1_Long Pine Key v
Icl|KY290250.1_Long Pine Key v
SPARFlavi01
SPARFlavi02
KC181923.1 Aedes flavivirus st
NC_024017.1 Nhumirim virus
HQ634598.1 Culex flavivirus
HQ634594.1 Culex flavivirus
NC_027819.1 Mercadeo virus
KP688058.1 Mercadeo virus

Icl|KY290256.1_Long Pine Key V Icl|KY290255.1 Long Pine Key v IcI|KY290254.1_Long Pine Key v IcI|KY290253.1_Long Pine Key Icl|KY290251.1_Long Pine Key v Icl|KY290249.1_Long Pine Key v IcI|KY290250.1_Long Pine Key v SPARFlavi01 SPARFlavi02

KC181923.1 Aedes flavivirus st NC_024017.1 Nhumirim virus HQ634598.1 Culex flavivirus HQ634594.1 Culex flavivirus NC_027819.1 Mercadeo virus KP688058.1 Mercadeo virus

Icl|KY290256.1_Long Pine Key V IcI|KY290255.1 Long Pine Key v IcI|KY290254.1_Long Pine Key v Icl|KY290253.1_Long Pine Key IcI|KY290251.1_Long Pine Key v Icl|KY290249.1_Long Pine Key v IcI|KY290250.1_Long Pine Key $y$ SPARFlavi01

SPARFlavi02

KC181923.1 Aedes flavivirus st NC_024017.1 Nhumirim virus HQ634598.1 Culex flavivirus HQ634594.1 Culex flavivirus NC_027819.1 Mercadeo virus KP688058.1 Mercadeo virus

Icl|KY290256.1_Long Pine Key V IcI|KY290255.1 Long Pine Key v IcI|KY290254.1_Long Pine Key Icl|KY290253.1 Long Pine Key Icl|KY290251.1_Long Pine Key v IcI|KY290249.1_Long Pine Key v Icl|KY290250.1_Long Pine Key v SPARFlavi01 SPARFlavi02

KC181923.1 Aedes flavivirus st NC 024017.1 Nhumirim virus HQ634598.1 Culex flavivirus

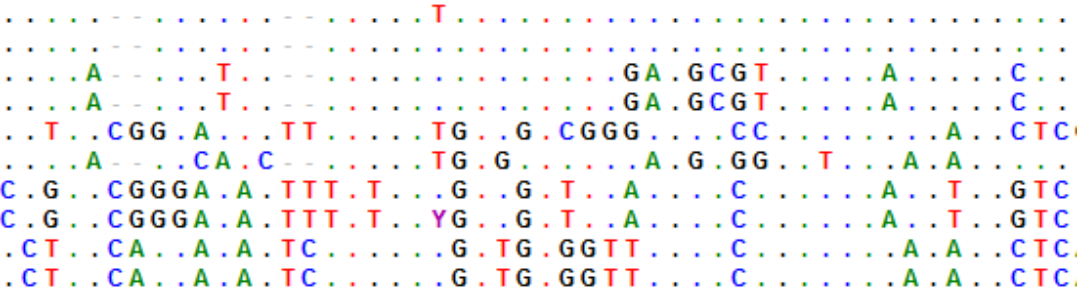

$$
520
$$$$
530
$$

540

550

AACTCATACGCATGGCGGAGAGTGAGGGAG TTAT TACTGATGGCGACGTG

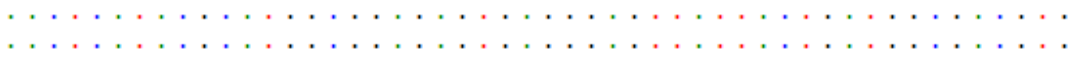

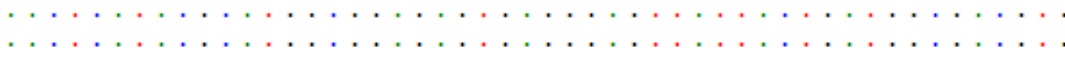
G T A A A A A C C C C C A A

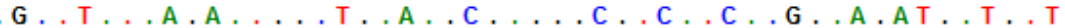

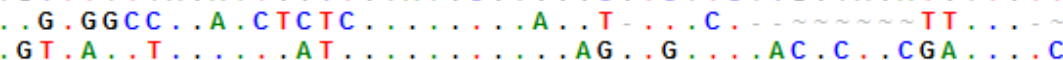

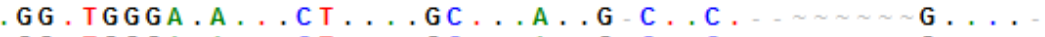

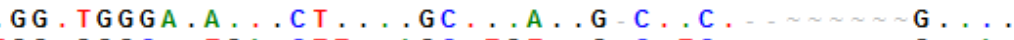

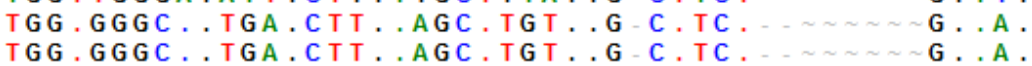

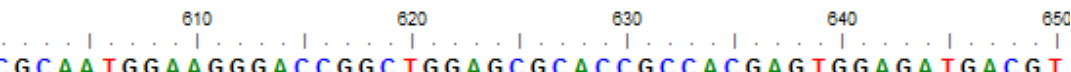

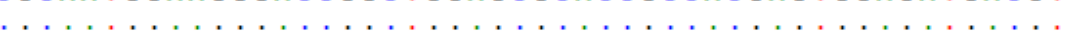

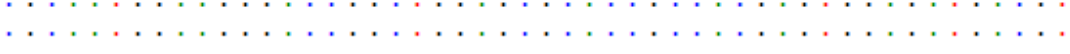

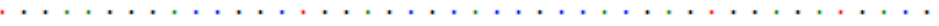

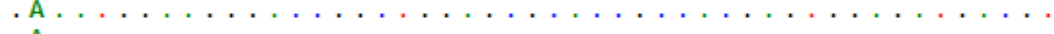

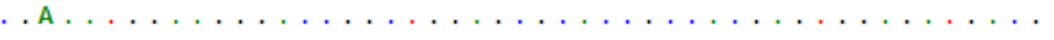
$\ldots \mathrm{C} \ldots \mathrm{A} \ldots \mathrm{A} \ldots \mathrm{AT} . \mathrm{A} \ldots \mathrm{A} \ldots \mathrm{T} \ldots \mathrm{C} \ldots \mathrm{T} \mathrm{TG}$ $\ldots$. . . . . . . AT A . . . . . . . . . T T

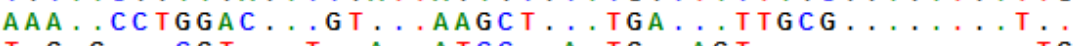
$T . G . G \ldots C G T \ldots T \ldots A \ldots A T C C \ldots A . T G \ldots A G T \ldots . . . . . T G$

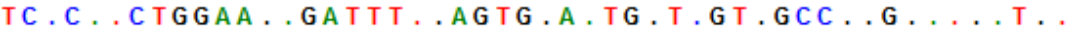
TC.C. C T TGGA..GATTT. A A T T . A. TG. T.GT.GCC. . . . . . . .

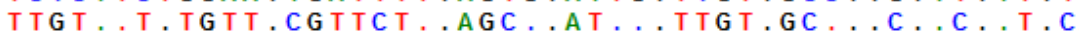

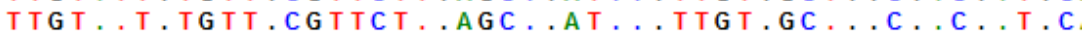

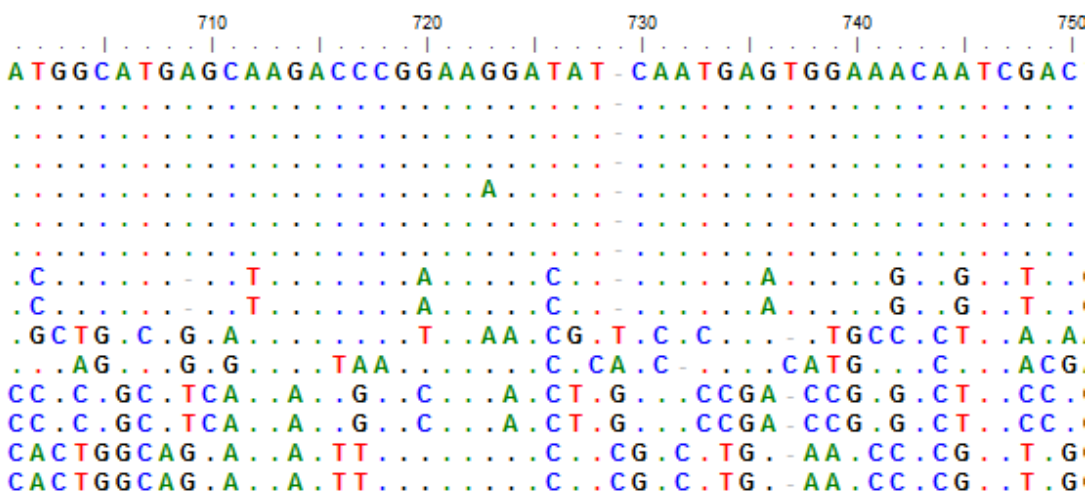

$$
810 \quad 820 \quad 830 \quad 840 \quad 850
$$

AGCTACAGT TGCGCGACGGAAGGAGCATAGTCGTCCCATGTAGATGTCAA

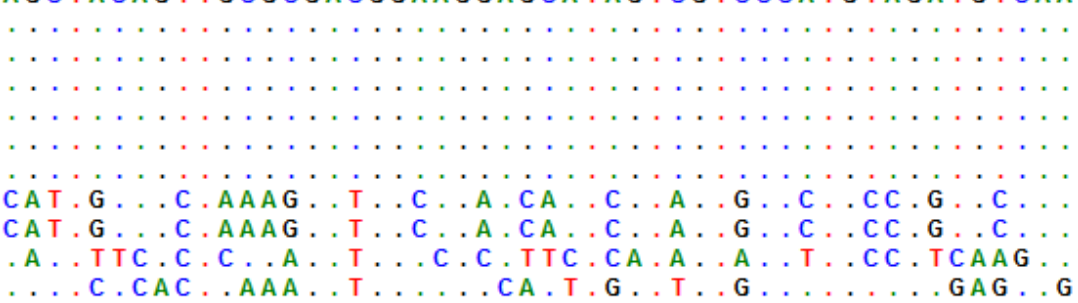

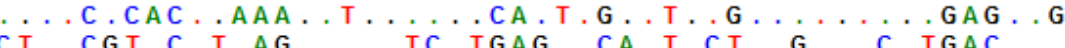


HQ634594.1 Culex flavivirus NC 027819.1 Mercadeo virus KP688058.1 Mercadeo virus

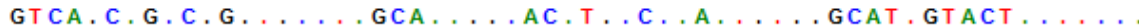

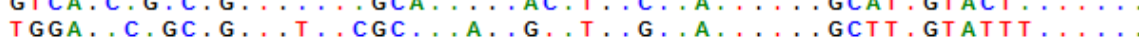

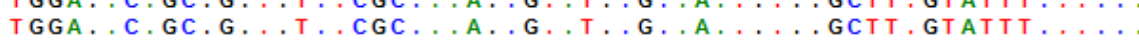

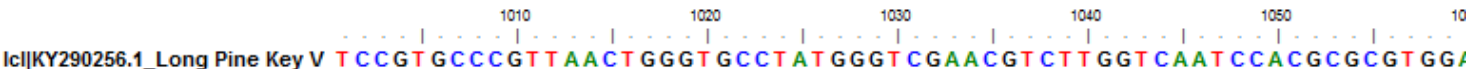
ICI|KY290255.1 Long Pine Key y

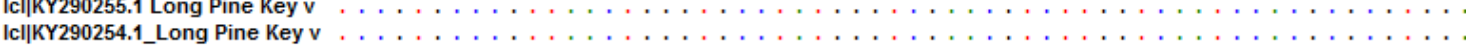
Icl|KY290253.1_Long Pine Key IcI|KY290251.1_Long Pine Key v IcI|KY290249.1_Long Pine Key v Icl|KY290250.1_Long Pine Key y SPARFlavi01 SPARFlavi02

KC181923.1 Aedes flavivirus st NC_024017.1 Nhumirim virus HQ634598.1 Culex flavivirus HQ634594.1 Culex flavivirus NC_027819.1 Mercadeo virus KP688058.1 Mercadeo virus

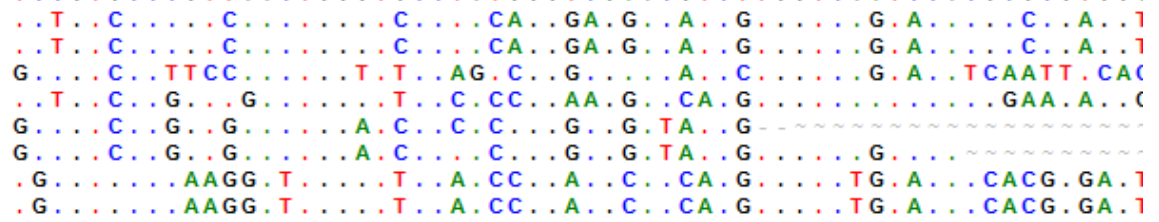

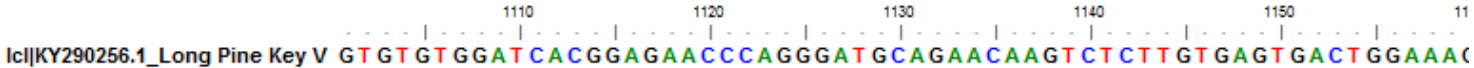

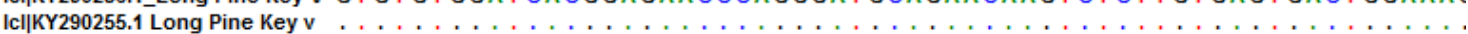

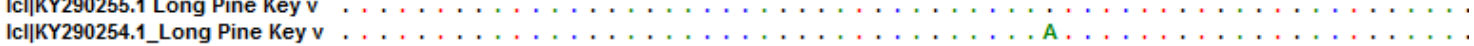

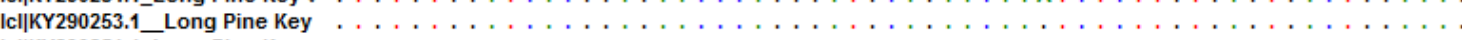
Icl|KY290251.1_Long Pine Key v

Ic||KY290249.1 Long Pine Key v Icl|KY290250.1_Long Pine Key v

C

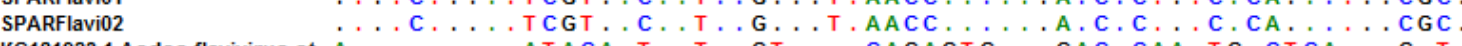
KC181923.1 Aedes flavivirus st A . . . . . . A T ACA. T . T . . GT . . . CAGAGT G . . GAC. CAA. T G. CT CA . . G. T .

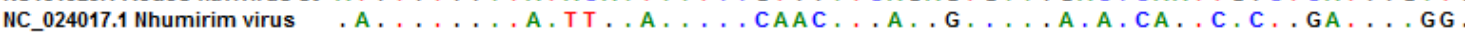
HQ634598.1 Culex flavivirus HQ634594.1 Culex flavivirus IC 027819.1 Mercadeo vir KP688058.1 Mercadeo virus

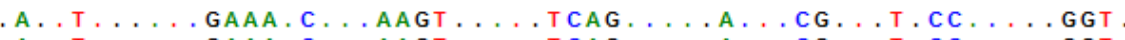
A. . . . . . . . . . . . . . . . . . . . . . . . . . . . . . . .

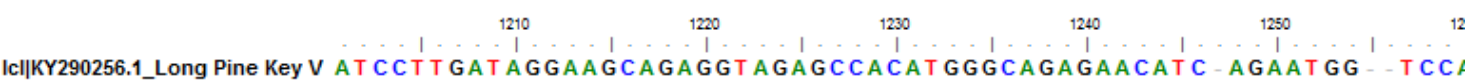

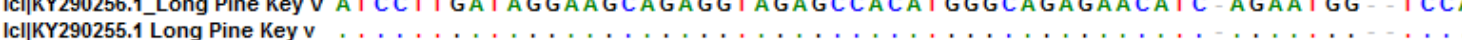

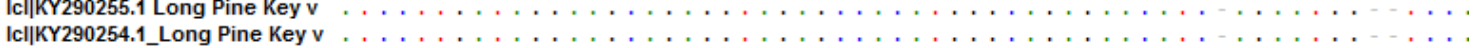

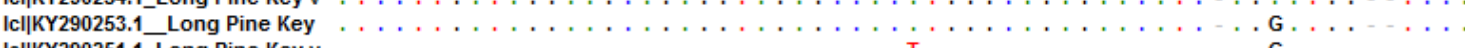

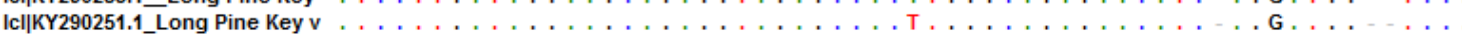

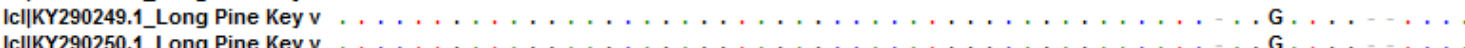

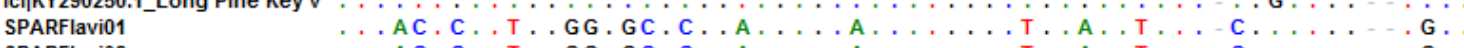

SPARFlavi02

KC181923.1 Aedes flavivirus st NC_024017.1 Nhumirim virus HQ634598.1 Culex flavivirus HQ634594.1 Culex flavivirus NC 027819.1 Mercadeo virus KP688058.1 Mercadeo virus

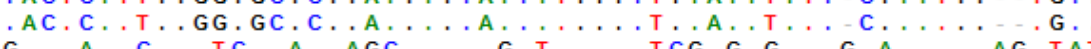

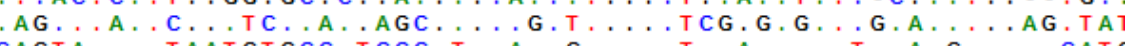

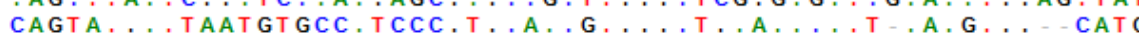

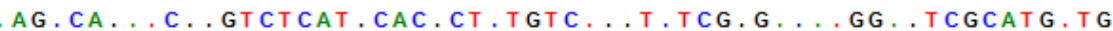
AG. CA... . . . GT CT CAT. CAC.CT.TGTC...T.TCG.G...GG. TCGCATG.TG

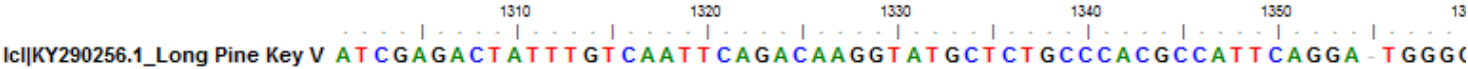

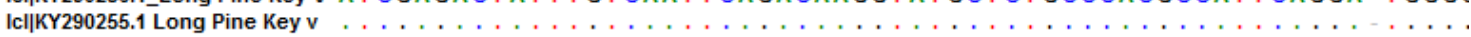

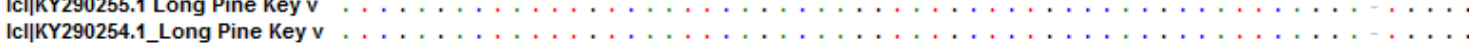

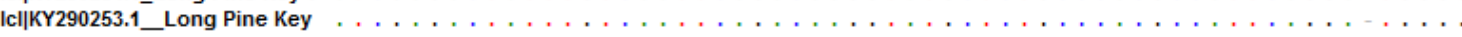

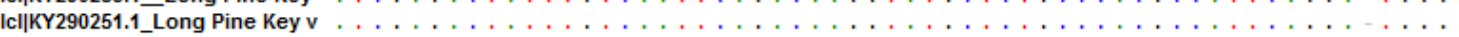

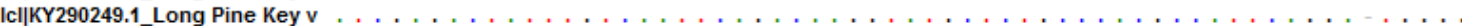
Ic||KY290250.1 Long Pine Keyv SPARFlavi01 SPARFlavi01

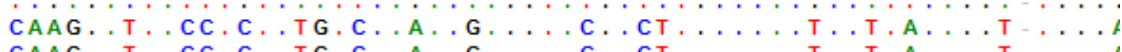

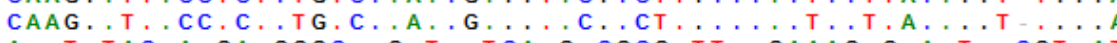

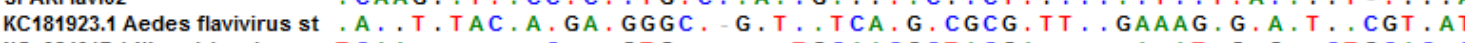

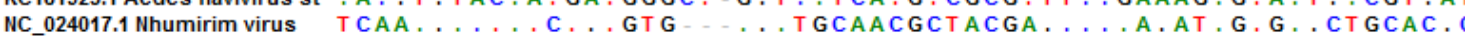
HQ634598.1 Culex flavivirus HQ634594.1 Culex flavivirus NC_027819.1 Mercadeo virus KP688058.1 Mercadeo virus
GA $\sim$ T T, CCGAACGCT C, T, GA, T, T, CGCGCGATA, GCAAAGCCGG, A, T G, CAT GA $\sim$ T T. CCGAACGCTC. T.GA.T.T.CGCGCGATA.GCAAAGCCGG.A.TG. CAT 1

\subsection{FILOGENIA}


A árvore filogenética de nucleotídeos gerada a partir dos isolados SPAR158533, SPAR158517 e SPR158584, identificados como vírus llheus, está demonstrada na Figura 14, utilizando-se o vírus Rocio como grupo externo. Os números próximos a cada nó representam os valores de "bootstrap" (1.000 repetições) e a escala representa o número de substituições/sítio.

Figura 14 - Árvore filogenética (nucleotídeos) do vírus llheus para a região parcial da NS5 gerada por meio do método de Máxima Parcimônia baseada no modelo Kimura 2-parâmetro. Os números próximos a cada nó representam os valores de 1000 repetições de bootstrap. A escala representa o número de substituições/sítio.

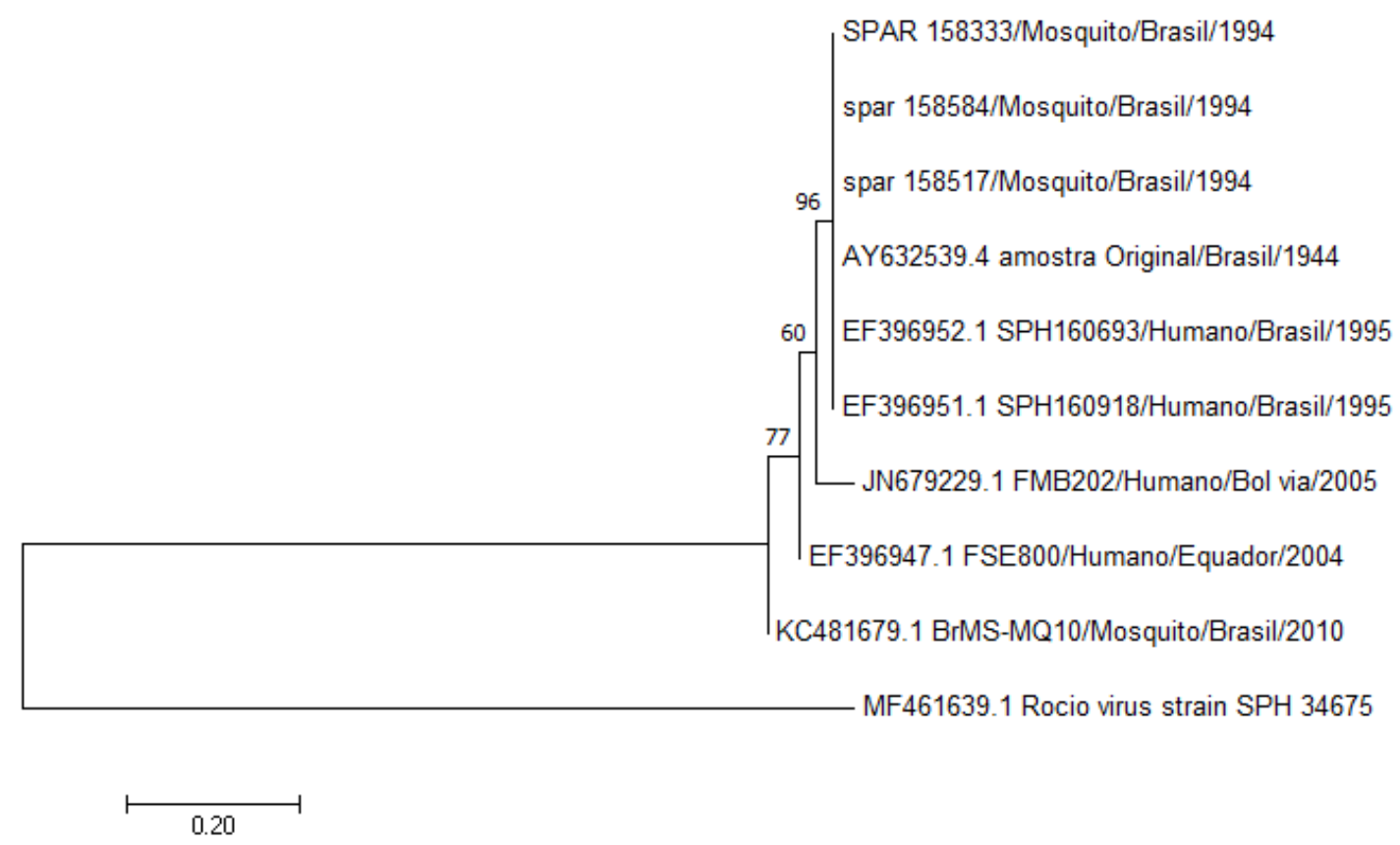

As similaridades nucleotídicas do fragmento de NS5 encontradas para os vírus llheus no presente estudo variaram de $97,1 \%$ a $100 \%$ entre elas, sendo as amostras SPAR 158333, SPAR 158495 e SPAR 158584 100\% idênticas. Quando comparadas com os demais isolados presentes no GenBank, as similaridades variaram de $81,1 \%$ a $98,5 \%$. As amostras caracterizadas como vírus Iguape tiveram $100 \%$ de homologia de nucleotídeos entre elas e $83,4 \%$ com a amostra original SPAn 71686 (número de acesso AY632538). 
Com o intuito de se observar a divergência do flavivírus encontrado em mosquitos Aedes terrens e Aedes scapularis com outros flavivírus específicos a insetos, foram construídas árvores pelo método de Máxima Parcimônia baseadas no modelo Kimura 2-parâmetro e no modelo JTT, baseada em nucleotídeos e em aminoácidos, respectivamente, demonstradas nas Figuras 15 e 16.

Pode-se observar, em ambas as árvores, que o flavivírus isolado forma um clado com os vírus Long Pine Key, isolados nos EUA em 2013, e com o vírus Nhumirim, isolado no Pantanal a partir de mosquito do gênero Culex em 2010.

Figura 15 - Árvore filogenética (nucleotídeos) de Flavivirus isolado a partir de mosquitos do gênero Aedes para a região parcial de 1374 nt da NS5 gerada pelo método de Máxima Parcimônia baseada no modelo Kimura 2-parâmetro. Os números próximos a cada nó representam os valores de 1000 repetições de bootstrap. A escala representa o número de substituições/sítio. Estão representados na figura valores acima de 70 .

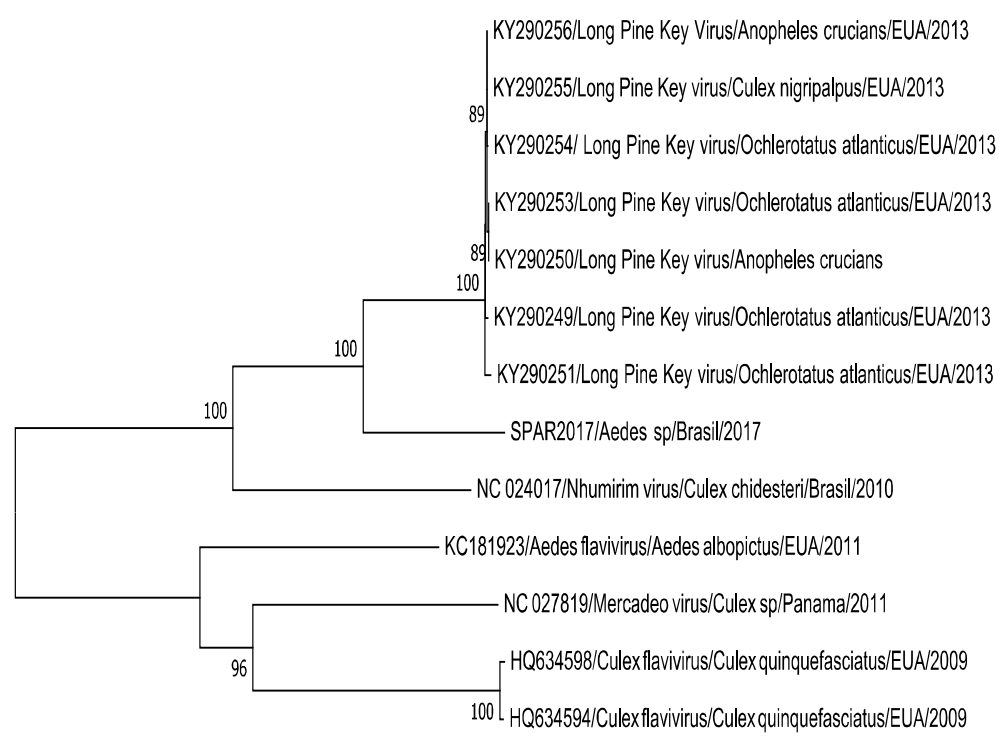


Figura 16 - Árvore filogenética (aminoácidos) de Flavivirus isolado a partir de mosquitos do gênero Aedes para a região parcial de 1374 nt da NS5 gerada por meio do método de Máxima Parcimônia baseada no modelo JTT. Os números próximos a cada nó representam os valores de 1000 repetições de bootstrap. A escala representa o número de substituições/sítio. Estão representados na figura valores acima de 70 .

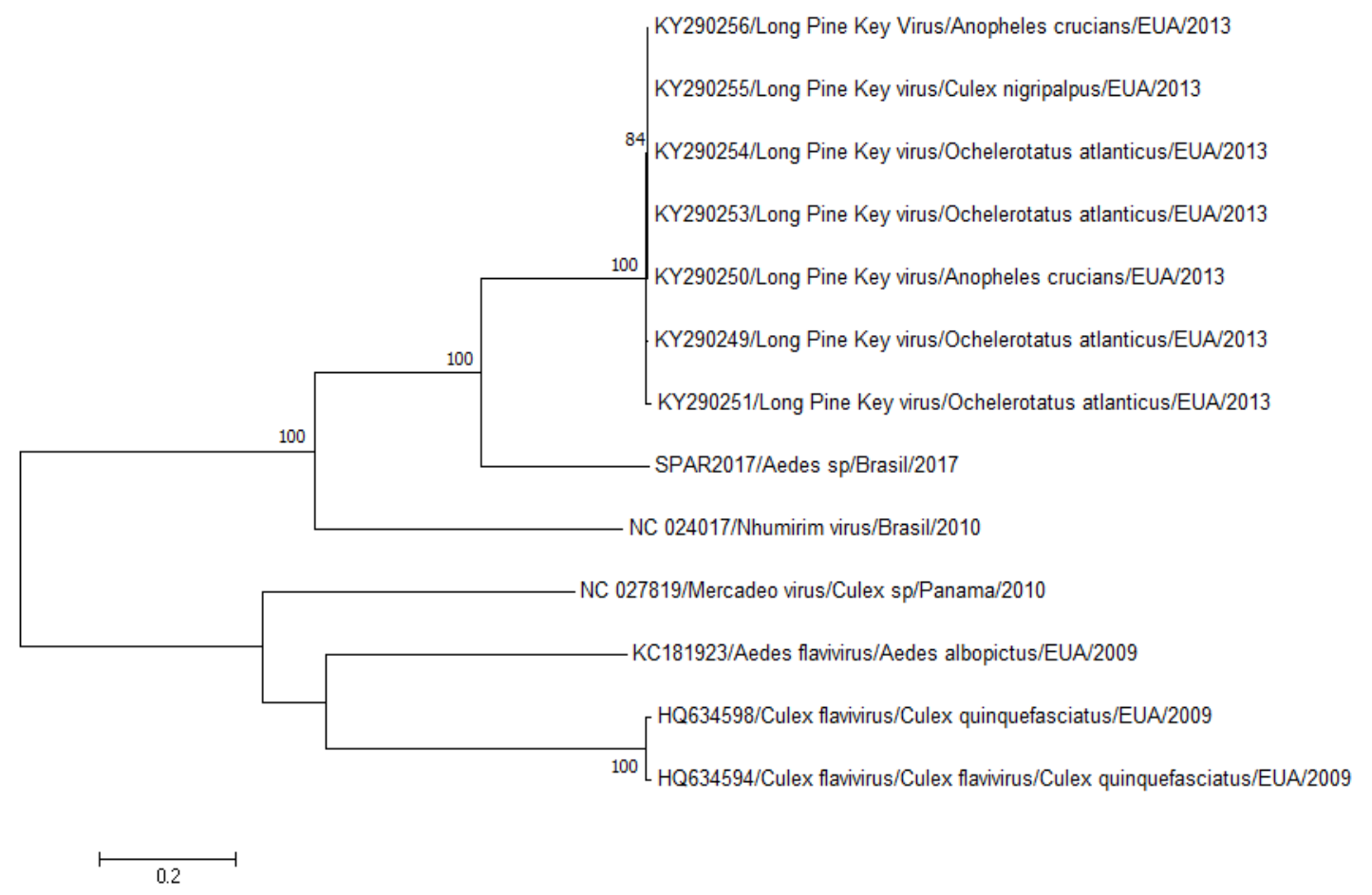

A matriz de identidade de nucleotídeos entre o fragmento gerado da amostra SPAR2017 e os demais flavivírus específicos de insetos obtiveram similaridades que variaram de $75,5 \%$ a $75,1 \%$ quando comparados com os isolados de Long Pine Key virus, $61,9 \%$ com vírus Nhumirim, 51\% para o Aedes flavivirus, 48,7\% para Mercadeo virus, e $40,3 \%$ e $39,2 \%$ com Culex flavivirus, enquanto que matriz de identidade de aminoácidos entre o fragmento gerado da amostra SPAR2017 e os demais flavivírus específicos de insetos obtiveram similaridades que variaram de $58,5 \%$ a $57,7 \%$ quando comparados com os isolados de Long Pine Key virus, 40,2\% com vírus Nhumirim, 27\% para o Aedes flavivirus, 26,3\% para Mercadeo virus, e $23,8 \%$ e $22,5 \%$ com Culex flavivirus, o que sugere a possibilidade de este ser um novo vírus pertencente ao gênero Flavivirus, encontrado em mosquitos Aedes.

\section{DISCUSSÃO}




\subsection{DETECÇÃO E VIGILÂNCIA DE FLAVIVÍRUS}

Doenças causadas por arbovírus emergentes e re-emergentes têm, atualmente, grande importância no contexto das enfermidades infecciosas, graças ao aumento de incidência em diversas partes do mundo (ERLANGER et al., 2009; FROST et al., 2012; MACKENZIE; GUBLER; PETERSEN, 2004). Vírus pertencentes ao gênero Flavivirus, em especial, incluem patógenos relacionados a doenças em humanos e animais, com propensão a se disseminarem para novas áreas geográficas, onde podem causar graves impactos sociais e econômicos. Têm-se como exemplos a ocorrência e disseminação do vírus do Oeste do Nilo nos Estados Unidos (LANCIOTTI et al., 1999), do vírus da Encefalite Japonesa na Austrália (HANNA et al., 1999), e os vírus Usutu, Oeste do Nilo e Dengue na Europa (GUZMAN; HARRIS, 2017; MARCANTONIO et al., 2015; ZIEGLER et al., 2015). Além disso, fatores como rápida e má urbanização, trânsito de pessoas e animais, e também o desflorestamento, podem contribuir para esta expansão (BHATT et al., 2013; PETERSEN; MARFIN, 2005).

Muitos flavivírus são agentes zoonóticos, dependendo de diversos vetores que se alimentam em animais nos quais se replicam para término do ciclo. Em países onde ocorre circulação de múltiplos agentes virais, é importante que se faça o diagnóstico diferencial dos mesmos, auxiliando dessa forma a vigilância e o controle de certas doenças (CALLAHAN et al., 2001). As técnicas usadas para este fim devem ser rápidas, reprodutíveis e capazes de detectar uma ampla gama de agentes com alta sensibilidade.

Dessa forma, uma vigilância ampla e sensível, visando uma detecção etiológica, pode servir como triagem para um monitoramento viral em determinadas áreas. São realizadas para isso pesquisas de arbovírus em pools de mosquitos e aves sentinelas em países Europeus (CHAINTOUTIS et al., 2014; CHASKOPOULOU et al., 2013; OSÓRIO et al., 2014; ZIEGLER et al., 2015), no Japão (HOSHINO et al., 2012), Índia (ARUNACHALAM et al., 2008) e Taiwan 
(YANG et al., 2010). Tal ferramenta pode ainda servir como um alerta prévio aos sistemas de saúde, especialmente nos casos de vírus re-emergentes ou emergentes para os quais a população é susceptível e não há vacina disponível (CHIU et al., 2017).

A captura de mosquitos é também amplamente utilizada nos Estados Unidos da América. Em 2000, o Centro de Controle de Doenças e Prevenção dos EUA (CDC) estabeleceu uma rede com o intuito de fazer vigilância para o vírus do Oeste do Nilo, visando elaborar um guia para profissionais da área da saúde para sua detecção, monitoramento e prevenção, que foi ampliada em 2003 para outras arboviroses, na qual os departamentos de saúde fazem notificações semanais de detecção destes vírus em humanos, animais e mosquitos (CENTRO DE CONTROLE DE DOENÇAS, 2013). Os indicadores gerados a partir da vigilância em vetores podem levar a ações de controle, que podem minimizar a amplificação viral, diminuindo assim chances de um surto em populações animais ou humanas. A vigilância do vírus do Oeste do Nilo nos Estados Unidos a partir da vigilância em mosquitos mostrou ser melhor quando comparada a outros métodos, como uso de animais sentinelas ou investigações a partir do relato de aves mortas (CENTRO DE CONTROLE DE DOENÇAS, 2013). Além disso, a detecção em artrópodes pode ser útil para identificar possíveis vetores ainda desconhecidos (PHILIP SAMUEL; TYAGI, 2006).

$\mathrm{O}$ isolamento viral em cultivos celulares ou em camundongos neonatos são ainda os testes padrão ouro para confirmação viral (LANCIOTTI et al., 2000; SAVAGE et al., 1999), porém, atualmente, métodos moleculares vêm substituindoos em alguns casos por serem mais sensíveis para esta deteç̧ão em pool de mosquitos (LANCIOTTI et al., 2000; NASCl et al., 2002). O uso de camundongos para diagnóstico e atividades de vigilância vem sendo diminuído por questões éticas de acordo com programas de redução, refinamento e substituição do uso de animais, havendo ainda desvantagem por problemas com contaminação das amostras e falha no isolamento de vírus específicos de insetos. São descritos em literatura diversos protocolos para a maior parte dos flavivírus, existindo ainda ensaios que detectem o gênero a partir da NS5 ou NS5 e região $3^{`} \mathrm{NC}$, seja por RT- 
PCR convencional (BRONZONI et al., 2005; FIGUEIREDO et al., 1998; FULOP et al., 1993; KUNO, 1998b; SCARAMOZZINO et al., 2001; TANAKA, 1993) ou RTqPCR com sondas do tipo TaqMan (PATEL et al; 2013) ou SYBR GREEN (JOHNSON et al., 2010; MOUREAU et al., 2007). A NS5 é a maior e mais conservada proteína não estrutural dos flavivírus, abrigando a atividade de RNA polimerase RNA dependente, que é necessária para replicação e transcrição do genoma viral (CHOl et al., 2004).

Uma das vantagens da RT-qPCR do tipo TaqMan, quando comparada à convencional, é o aumento da especificidade, uma vez que se utilizam sondas específicas durante a amplificação. Além disso, como o cDNA amplificado não é manipulado no laboratório, diminui-se a chance de contaminação do amplicon (LANCIOTTI, 2003). Outro fator importante é a rapidez do teste, bem como a possibilidade de se testar um grande número de amostras em uma única corrida, como é o caso de se testar pools de mosquitos coletados em estudos de monitoramento viral, quando são coletados diversos indivíduos dependendo do local e da estação do ano. Vale ressaltar ainda que, na RT-PCR, a observação de bandas em gel de poliacrilamida é a análise final para a interpretação qualitativa do resultado e, dessa forma, introduz-se a subjetividade do leitor, que pode levar a erros. Além disso, a reação de RT-qPCR do tipo TaqMan permite o sequenciamento direto do cDNA gerado na placa sem a presença de bandas inespecíficas e dimers, geralmente visualizados nos géis de poliacrimilamida, e sem a necessidade de purificação do mesmo, como demonstrado no presente estudo, quando foram sequenciados vírus isolados de mosquitos capturados no ano de 1994, e que estavam até este momento armazenados sem identificação, relatando assim a ocorrência dos vírus lguape e llheus em culicídeos de diferentes espécies, e também a identificação do primeiro isolado de vírus Zika no Brasil, uma vez que este não tinha sua circulação no país e, portanto, não constava no rol de diagnósticos diferenciais para quadros compatíveis com dengue.

A RT-PCR com oligoiniciadores descritos por Figueiredo e colaboradores (1998), em formato one-step, foi capaz de identificar os flavivírus circulantes no Brasil, com exceção do VBSQ, sem descrever os limites de detecção dos mesmos. A duplex RT-PCR seguida de nested-PCR para identificação de flavivírus descrita 
por Bronzoni e colaboradores (2005) descreve um limite de detecção para o vírus da Febre Amarela de $10^{1.3}$ TCID50/ml, porém, sem avaliação de VCPC e VIGP, cujo presente estudo detectou uma sensibilidade de 0,1 UFP e 1 UFP, respectivamente. Nestes estudos, também não foi avaliado o VZIK, que foi introduzido recentemente no país, cuja detecção foi de 0,1 UFP. Ademais, avaliou-se que o protocolo de RTqPCR aqui testado foi capaz de amplificar o vírus Bussuquara, apresentando um

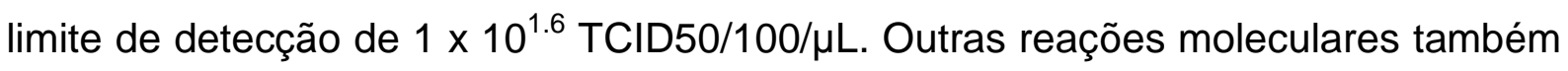
não relatam a detecção de grande parte dos vírus de ocorrência no Brasil (SCARAMOZZINO et al., 2001; TANAKA, 1993).

Quando comparados com a detecção do gênero Flavivirus por SYBR Green, os valores de sensibilidade para alguns vírus são similares (YANG et al., 2010), porém, sem a necessidade de se analisar a curva de melting, sem a qual podem ser gerados resultados falso positivos. Os iniciadores descritos por Johnson e colaboradores (2010) foram somente avaliados para oito flavivírus, entre os quais somente o vírus Dengue com ocorrência no Brasil, e testados para diversos isolados do vírus Oeste no Nilo com Cts menores quando comparados aos específicos, enquanto que o protocolo descrito por Moureau e colaboradores (2007) avaliou primers para 86 amostras de 51 espécies virais e 3 espécies tentativas, com limites de detecção que variaram de 3 a 50 cópias de RNA por reação, dependendo do vírus.

Descreve-se, ainda, na literatura, uma RT-qPCR multiplex capaz de identificar 8 flavivírus de importância médica em mosquitos (CHAO; DAVIS; CHANG, 2007), o qual teve $100 \%$ de especifidade, com sensibilidades de $3.5 \mathrm{UFP} / \mathrm{mL}$ para o VFA (Ct igual a 40.8) e $10 \mathrm{UFP} / \mathrm{mL}$ para o VESL (Ct igual a 41.6).

O protocolo de Patel e colaboradores (2013), cujos limites de detecção encontrados foram de 100 cópias para o vírus vacinal da Febre Amarela, com Ct de 36,4 , e de 10 cópias para o vírus da Dengue sorotipo 1, com Ct de 39,7, não descrevem a eficiências e nem os limites de detecção para grande parte dos vírus circulantes no Brasil, os quais foram descritos no presente trabalho. Uma vez que não existem protocolos específicos para os vírus Cacipacore, llheus, Iguape e Bussuquara, é de suma importância que os órgãos responsáveis considerem estes 
flavivírus como diagnóstico diferencial em amostras de fase aguda de pacientes febris dengue negativos, bem como quando da realização de monitoramento viral em mosquitos. Dessa forma, conhecer-se-iam as reais prevalências dessas arboviroses em humanos ou em que ambientes eles circulam atualmente, e em quais espécies de vetores, possibilitando estudos de competência vetorial para estes vírus. Uma outra vantagem seria também uma possível vigilância de epizootias no Brasil, uma vez que aves e equinos atuam como hospedeiros de grande parte destes vírus, sendo alguns deles sensíveis a eles, em especial cavalos para os vírus da Encefalite de Saint Louis (ROSA et al., 2013) e as linhagens 1 e 2 do vírus do Oeste do Nilo relatados na Europa, Estados Unidos e África do Sul (AHARONSONRAZ et al., 2014; CANTILE et al., 2001; VENTER et al., 2009), algumas aves (LANCIOTTI et al., 2000) e animais de zoológico nos EUA (LANCIOTTI et al., 2000) e Dubai (JOSEPH et al., 2016). Esta vigilância a partir de animais é o que prega a questão da Saúde Única, na qual a saúde dos animais e do meio ambiente está ligada à saúde humana, já que a detecção prévia de patógenos pode levar a uma ação de controle que diminua o risco de infecção em seres humanos. No Brasil, a única doença transmitida por artrópode com esta característica é a Febre Amarela, que passou a ser preconizada para a vigilância no estado de São Paulo no ano de 1999, uma vez que amostras de primatas não humanos encontrados doentes ou mortos são enviadas ao NDTV do IAL para detecção viral, já que esta desencadeia a vacinação de uma população susceptível, servindo, portanto, como um alerta à Saúde Pública (MINISTÉRIO DA SAÚDE, 2017d).

Além de mosquitos, existem ainda flavivírus transmitidos por carrapatos de importância médica e veterinária em outras partes do mundo, entre eles o vírus da encefalite transmitida por carrapatos, causador de infecções neurológicas em humanos em países da Europa e Ásia (GRITSUN; LASHKEVICH; GOULD, 2003), o vírus da Febre Hemorrágica de Omsk, vírus Powassan, vírus Langat, vírus da Doença da Floresta Kyasanur e Louping ill vírus, todos causadores de doenças em mamíferos (GRITSUN; NUTTALL; GOULD, 2003). No Brasil, país com muitos arbovírus descritos, houve somente uma descrição recente do flavivírus Cacipacore em carrapatos (DE FIGUEIREDO et al., 2017). Nesse sentido, seria interessante que se fizessem mais estudos que busquem vírus nesses vetores, utilizando-se a técnica de RT-qPCR, que mostrou ter alta sensibilidade e especifidade para os flavivírus de 
ocorrência no país.

Lanciotti e colaboradores (2003) observaram, em geral, uma queda na sensibilidade com o uso de oligoiniciadores degenerados quando comparados com os específicos sem degenerações, encontrando diferenças cuja redução de sensibilidade variou de 10 a 100 vezes com o vírus do Oeste do Nilo. O presente estudo comparou os limites de detecção dos vírus da Febre Amarela, Encefalite de Saint Louis e Zika com aqueles obtidos por meio de RT-qPCR com os oligoiniciadores específicos descritos em literatura (DOMINGO et al., 2012; DYER; CHISENHALL; MORES, 2007; LANCIOTTI et al., 2008). Os valores obtidos foram de 1 UFP, 0,1 e 0,1 UFP/mL, respectivamente, resultados estes compatíveis com o descrito acima, com exceção do vírus Zika, cujo limite de detecção foi igual nos testes, tendo-se como corte valores de Ct de até 38,5 (LANCIOTTI et al., 2008). Estima-se que aproximadamente 500 partículas de cópias de RNA sejam necessárias para produzir 1 UFP para o vírus do Oeste do Nilo (SHI et al., 2001), o que mostra que o protocolo utilizado tem boa sensibilidade, ainda que 10 ou 100 vezes menor quando comparada com primers específicos, podendo, dessa forma, substituir a técnica de isolamento em camundongos neonatos nas pesquisas de campo realizadas pela equipe do NDTV, em amostras de vetores e/ou animais, ou para diagnóstico diferencial de quadros compatíveis com arboviroses, realizando a pesquisa do gênero Flavivirus em uma única reação, seguida de sequenciamento em amostras positivas, economizando, dessa forma, reagentes. Quando comparados com o isolamento em células C6/36, o método de RT-qPCR demonstrou ter maior sensibilidade para os flavivírus testados, com exceção do VBSQ, que teve como limite de detecção $1 \times 10^{1,6}$ TCID50/100 $\mu$ L nesta técnica, e $1 \times 10^{0,6}$ TCID50/100 $\mu \mathrm{L}$ no isolamento em células C6/36. No entanto, a vantagem do método molecular é a possibilidade da detecção em amostras em que os vírus não estejam mais viáveis para o isolamento.

\subsection{USO DA RT-QPCR PARA DIAGNÓSTICO DIFERENCIAL DE FLAVIVÍRUS}




\subsubsection{Vírus Zika}

O vírus Zika, até recentemente, era pouco relatado em seres humanos, sendo que sua ocorrência era descrita em países da África e da Ásia somente, sem casos graves associados (FAGBAMI, 1979; OLSON et al., 1981). No entanto, a partir da metade da primeira década do século XXI, foram descritos os primeiros surtos a ele relacionados nas ilhas do Pacífico Sul (DUFFY et al., 2009, CAO-LORMEAU, 2014; MUSSO, NILLES, CAO-LORMEAU, 2014). Porém, é esperado que alguns vírus, em especial os flavivírus, que têm diferentes ciclos de transmissão, e que possuem diferentes hospedeiros e vetores, tenham a capacidade de se disseminar para novas áreas, onde encontram uma população susceptível, seja graças a alterações ambientais causadas principalmente pelo homem, migrações de animais ou devido à globalização. Assim, é importante que orgãos ligados à vigilância, bem como os laboratórios de pesquisa e saúde, estejam atentos à entrada de novos patógenos no país, que possui em grande escala mosquitos hematófagos de diferentes espécies que podem atuar como vetores competentes de diversos vírus. O presente estudo pôde, dessa forma, colaborar nesse sentido, uma vez que foi capaz de identificar o vírus Zika em uma amostra de soro, a partir do qual foi isolado em células C6/36 um flavivírus de um doador de sangue em março de 2015, sendo este o primeiro isolado do vírus no país (CUNHA et al, 2016).

Uma vez que o VZIK não era ainda descrito no país, a hipótese diagnóstica gerada pela equipe médica foi dengue, e somente o protocolo multiplex de RTqPCR, descrito por Johnson e colaboradores (2005) para os sorotipos 1, 2, 3 e 4 foi utilizado. O presente estudo sugere, portanto, que se façam diagnósticos diferenciais em amostras de pacientes febris negativos para dengue, Zika e Chikungunya, ou de viajantes, uma vez que se mostrou que a técnica aqui validada tem boa sensibilidade para a deteç̧ão dos diversos flavivírus que ocorrem no Brasil, e que pode ser realizada em uma única corrida de RT-qPCR de uma forma simples e rápida, sendo o vírus confirmado por reação de sequenciamento tipo Sanger, sem a necessidade de géis de agarose e sem riscos de contaminação. Ainda, o uso deste 
método pode detectar um flavivírus emergente no país antes que o mesmo se alastre.

\subsection{IDENTIFICAÇÃO DE FLAVIVÍRUS}

\subsubsection{Vírus llheus e Vírus Iguape}

O vírus llheus, identificado no presente estudo a partir de isolados de mosquitos Culex spp., Anopheles triannulatus e Coquilettidia juxtamansonia coletados na cidade de Juquitiba, São Paulo, raramente é associado a doença em humanos, e tais infecções podem não ser corretamente identificadas graças a falhas no diagnóstico e/ou presença de cruzamentos em testes sorológicos com os demais flavivírus. No entanto, no início dos anos 2000, o vírus foi identificado em humanos na Bolívia e no Equador com quadros febris exantemáticos (JOHNSON et al., 2007; VENEGAS et al., 2012). No caso da Bolívia, o vírus não foi isolado em células e nem em camundongos neonatos, demonstrando dessa forma a importância de métodos moleculares para detecção viral. No Brasil, foi isolado no Pantanal a partir de pool de mosquitos Aedes scapularis (PAUVOLID-CORREA et al., 2013), revelando sua circulação na América Latina. Os demais isolados de mosquitos descritos em literatura são a amostra original, isolada de Ochlerotatus e Psorophora spp., no Brasil, (LAEMMERT; HUGHES, 1947), Psorophora ferox (TURELL et al., 2005) e Culex coronator (dados não publicados) no Peru. De acordo com as relações entre os flavivírus e seus vetores, este vírus é associado a mosquitos do gênero Culex spp. e aves (GAUNT et al., 2001). Sua identificação em outras espécies de culicídeos, como mostrado no presente estudo, revela a importância de mais pesquisas acerca de seu papel na transmissão dos flavivírus no Brasil, indicando que investigações entomológicas devam ser realizadas com mais frequência.

Outro vírus identificado a partir de mosquitos Anopheles coletados em 1994 na cidade de Juquitiba foi o vírus Iguape, cujas sequências obtidas se mostraram idênticas entre elas. No entanto, não se sabe ainda qual o impacto deste vírus na saúde humana ou na dos animais, e nem os vetores implicados em seu ciclo. 
Além da identificação de vírus de baixa ocorrência, que pode alertar o sistema de saúde, e também uma maior compreensão de seus ciclos de transmissão, podese ampliar o conhecimento de seus mecanismos de evolução a partir de depósitos de novas sequências virais, bem como melhorar testes moleculares já conhecidos para sua detecção. Ao se disponibilizar tais sequências genômicas, espera-se que vírus emergentes sejam mais facilmente identificados no futuro, culminando com maior rapidez das medidas de controle (HOWARD; FLETCHER, 2012).

\subsubsection{Vírus ainda não descritos}

Sugere-se que o gênero Flavivirus contenha vírus ainda a serem identificados (PYBUS et al., 2002). O uso da técnica aqui descrita com oligoiniciadores degenerados, seguida de sequenciamento, possibilitou a identificação de um possível novo vírus específico de mosquitos, a partir de vírus isolados de pools de mosquitos Aedes terrens e Aedes scapularis capturados em Guapiaçu, SP, em 2017, gerando fragmentos de cerca de 200 pb, que mostrou ao redor de $80 \%$ de similaridade de nucleotídeos com diferentes isolados africanos do vírus do Oeste do Nilo. Quando a comparação foi feita com aminoácidos, estes flavivírus, que se mostraram idênticos, tiveram 93\% de similaridade com o vírus Long Pine Key, específicos de insetos, isolados em 2013 na Flórida, EUA, de diferentes mosquitos. Visando, portanto, uma confirmação destes vírus, um fragmento de 1576 da NS5 foi obtido após sequenciamento com primers descritos por Kuno e colaboradores (1998b) e comparado novamente através da ferramenta BLASTx, que revelou similaridades de aminoácidos entre 58,5\% e 57,7\% com o vírus Long Pine Key, o que pressupõe que este seja um vírus ainda não descrito, devido à baixa similaridade. Tanto a árvore filogenética de nucleotídeos (Figura 15) quanto a de aminoácidos (Figura 16) agruparam a amostra SPAR2017 em um clado com os vírus específicos Long Pine Key, Nhumirim e Aedes flavivirus, com altos valores de bootstrap.

O termo vírus específico a inseto refere-se a vírus que infectam naturalmente mosquitos, replicando in vitro em suas células derivadas, mas que não se replicam em células de mamíferos e infectam seres humanos e outros vertebrados. $O$ primeiro descrito, isolado há 40 anos, foi o flavivírus Cell fusion agent virus (CFAV), 
que apresentou 45\% de similaridade de aminoácidos da NS5 com os vírus previamente descritos (STOLLAR; THOMAS, 1975). Durante as últimas décadas, outros foram isolados e identificados em diversas localidades (BOLLING et al., 2011; BOLLING et al., 2015; FERREIRA et al., 2013; HADDOW et al., 2013; KOLODZIEJEK et al., 2013; PAPA et al., 2014; ZUO et al., 2014), entre eles Kamiti River virus (KRV), Culex flavivirus (CxFV), Spanish Culex flavivirus, Culex theileri flavivirus, Aedes flavivirus (AeFV), Aedes vexans flavivirus (AeveFV), Czech Aedes vexans flavivirus, Aedes galloisi flavivirus, Aedes cinereus flavivirus, Ochlerotatus flavivirus, Quang Binh virus, Nakiwogo virus, Calbertado virus, Chaoyang virus e Hanko virus, dentre outros, graças aos avanços das ferramentas de biologia molecular e sequenciamento de nova geração, bem como ao crescente interesse pelo microbioma de invertebrados.

Recentemente, no Brasil, na região do Pantanal, Pauvolid-Corrêa e colaboradores (2015) detectaram por meio de RT-qPCR SYBR Green®, seguido de sequenciamento da NS5, o vírus Nhumirim em pool de fêmeas de mosquitos Culex (Culex) chidesteri, capturados em abril de 2010. As amostras originais inoculadas em cultivos celulares não apresentaram efeito citopático em C6/36 e nem placas em células Vero. O fragmento de 218 pb teve $82 \%$ de similaridade com Barkedji virus (BJV), enquanto que o de 1061 pb teve 74\%. Posteriormente, a análise do genoma revelou somente 63\%. Kenney e colaboradores (2014) relataram que este vírus foi capaz de reduzir a replicação do Vírus do Oeste do Nilo, da Encefalite Japonesa e da Encefalite de Saint Louis em células C6/36, as quais, diferentemente dos moquitos, não possuem resposta antiviral por RNAi (BRACKNEY et al., 2010). No entanto, um estudo avaliou o efeito da infecção causada por vírus específicos na capacidade vetorial para arbovírus usando mosquitos Culex quinquefasciatus infectados com Vírus do Oeste do Nilo, comparando fêmeas infectadas experimentalmente com Culex flavivirus com não infectadas, não sendo observada, no entanto, alteração da replicação do Vírus do Oeste do Nilo (KENT; CRABTREE; MILLER, 2010). Por outro lado, verificou-se que uma cepa deste mosquito proveniente de Honduras inoculada simultaneamente com estes vírus teve aumento da transmissão do Vírus do Oeste do Nilo após 14 dias da infecção (KENT; CRABTREE; MILLER, 2010). Outro estudo comparou a capacidade vetorial do vírus do Oeste do Nilo em cepas de $C x$. pipiens do Colorado naturalmente infectadas com 
Culex flavivirus com a capacidade vetorial de $C x$. pipiens de lowa livres do mesmo (BOLLING et al., 2012), que demonstrou uma redução significativa da taxa de disseminação do Vírus do Oeste do Nilo após 7 dias de infeção.

Pouco se sabe ainda acerca das dinâmicas de transmissão que ocorrem naturalmente nos insetos, bem como o potencial dessas infecções nos mesmos. A descoberta de taís vírus e seus mecanismos de atuação podem ser importantes para compreender como eles poderiam modular a transmissão dos arbovírus na natureza. Considerando a grande biodiversidade brasileira e seus diferentes biomas, sua descrição é esperada, uma vez que a Amazônia brasileira é a fonte da maior variedade de arbovírus no mundo (VASCONCELOS et al., 2005). Além disso, tal busca pode levar a estudos para novas ferramentas para o controle de arbovírus que ocorrem no país, já que alguns trabalhos mostram evidências que alguns vírus específicos de mosquitos podem alterar a susceptibilidade a certos arbovírus patogênicos (BOLLING et al., 2012; KENT; CRABTREE; MILLER, 2010). 


\section{CONCLUSÕES}

O protocolo de RT-qPCR aqui testado foi capaz de:

- Detectar os vírus da Febre Amarela, Iguape, Ilheus, Encefalite de Saint Louis e Zika, com limites que variaram de 0,01 a 1 unidade formadora de placa $/ \mathrm{mL}$, e de $10^{1,6} \mathrm{TCID} 50 / 100 \mu \mathrm{L}$ para o vírus Bussuquara;

- Identificar o vírus Zika a partir de isolado de soro de um doador de sangue febril com suspeita de dengue;

- Identificar os vírus llheus e Iguape, isolados de mosquitos capturados a campo;

- Identificar um possível novo flavivírus isolado de mosquitos Aedes em células C6/36.

Dessa forma, conclui-se que o presente protocolo pode ser usado, através de uma reação $\mathrm{RT}$-qPCR single, tanto para diagnóstico diferencial de flavivírus em pacientes febris e animais, bem como em estudos de monitoramento viral, de forma rápida e sensível, podendo, ainda, detectar novos flavivírus específicos de artrópodes. 


\section{REFERÊNCIAS}

ADHIYAMAN, V.; OKE, A.; CEFAI, C. Effects of yellow fever vaccination. Lancet, v. 358, p. 1907-1908, 2001.

AHARONSON-RAZ, K. et al. Spatial and temporal distribution of West Nile virus in horses in Israel (1997-2013) from endemic to epidemics. PloS one, v. 9, n. 11, p. e113149, 2014.

ALDUNATE, F. et al. Evidence of increasing diversification of Zika virus strains isolated in the American continent. Journal of medical virology, v. 12, n. 89, p. 2059-2063, dez, 2017.

ALTSCHUL, S. F. et al. Basic local alignment search tool. Journal of molecular biology, v. 215, n. 3, p. 403-410, out. 1990.

ARTSOB, H. et al. West Nile Virus in the New World: Trends in the Spread and Proliferation of West Nile Virus in the Western Hemisphere. Zoonoses and Public Health, v. 56, n. 6-7, p. 357-369, 2009.

ARUNACHALAM, N. et al. Natural vertical transmission of dengue viruses by Aedes aegypti in Chennai, Tamil Nadu, India. The Indian journal of medical research, $v$. 127, n. 4, p. 395-397, abr. 2008.

AUGUSTE, A. J. et al. Enzootic Transmission of Yellow Fever Virus, Venezuela. Emerging Infectious Diseases, v. 21, n. 1, p. 99-102, jan. 2015.

AUGUSTE, A. J. et al. Yellow fever virus maintenance in Trinidad and its dispersal throughout the Americas. Journal of Virology, v. 84, n. 19, p. 9967-9977, out. 2010.

BARRETT, A. D.; MONATH, T. P. Epidemiology and ecology of yellow fever virus. Advances in Virus Research, v. 61, p. 291-315, 2003.

BARRETT, A. D. T.; HIGGS, S. Yellow fever: a disease that has yet to be conquered. Annual Review of Entomology, v. 52, p. 209-229, 2007.

BATISTA, P. M. et al. Detection of arboviruses of public health interest in free-living New World primates (Sapajus spp.; Alouatta caraya) captured in Mato Grosso do Sul, Brazil. Revista da Sociedade Brasileira de Medicina Tropical, v. 46, n. 6, p. 684-690, 2013.

BATISTA, W. C. et al. Notification of the first isolation of Cacipacore virus in a human in the State of Rondonia, Brazil. Revista da Sociedade Brasileira de Medicina Tropical, v. 44, n. 4, p. 528-530, 2011.

BECK, A. et al. Phylogeographic Reconstruction of African Yellow Fever Virus Isolates Indicates Recent Simultaneous Dispersal into East and West Africa. PLoS Neglected Tropical Diseases, v. 7, n. 3, p. e1910, 14 mar. 2013. 
BHATT, S. et al. The global distribution and burden of dengue. Nature, v. 496, n. 7446, p. 504-507, abr. 2013.

BOLLING, B. G. et al. Insect-Specific Flaviviruses from Culex Mosquitoes in Colorado, with Evidence of Vertical Transmission. The American Journal of Tropical Medicine and Hygiene, v. 85, n. 1, p. 169-177, 1 jul. 2011.

BOLLING, B. G. et al. Insect-specific viruses and their potential impact on arbovirus transmission. Current opinion in virology, v. 15, p. 69-74, 31 dez. 2015.

BOLLING, B. G. et al. Transmission dynamics of an insect-specific flavivirus in a naturally infected Culex pipiens laboratory colony and effects of co-infection on vector competence for West Nile virus. Virology, v. 427, n. 2, p. 90-97, jun. 2012.

BONALDO, M. C. et al. Isolation of infective Zika virus from urine and saliva of patients in Brazil. Plos Negleted Tropical Diseases, v. 10, n. 6, p. e0004816, 2016.

BONALDO, M. C. et al. Genome analysis of yellow fever virus of the ongoing outbreak in Brazil reveals polymorphisms Memórias do Instituto Oswaldo Cruz, v. 112, n. 6, p. 447-451, Junho 2017.

BRACKNEY, D. E. et al. C6/36 Aedes albopictus cells have a dysfunctional antiviral RNA interference response. PLoS neglected tropical diseases, v. 4, n. 10, p. e856, out. 2010.

BRASIL. Ministério da Saúde. Boletim Epidemiológico SVS: Monitoramento dos casos de dengue, febre de chikungunya e febre pelo vírus Zika até a Semana Epidemiológica 35. Brasília, DF, 2017a.

BRASIL. Ministério da Saúde. Boletim Epidemiológico SVS: Monitoramento integrado de alterações no crescimento e desenvolvimento relacionadas à infecção pelo vírus Zika e outras etiologias infecciosas, até a Semana Epidemiológica 28/2017. Brasília, DF, 2017b.

BRASIL. Ministério da Saúde. Secretaria de Vigilância em Saúde. Centro de Operações de Emergências em Saúde Pública sobre Febre Amarela. Informe 43/2017. Brasília, DF, 2017c.

BRASIL. Ministério da Saúde. Secretaria de Vigilância em Saúde Departamento de Vigilância das Doenças Transmissíveis. Guia de vigilância de epizootias em primatas não humanos e entomologia aplicada à vigilância da febre amarela. 2. ed. atualizada. Brasília, DF, 2017d.

BRASIL, P. et al. Guillain-Barré syndrome associated with Zika virus infection. The Lancet, v. IN PRESS, n. 10026, p. 1482, 2016.

BRINKER, K. R., MONATH, T. P. The acute disease. In: MONATH, T. P. St. Louis Encephalitis. Washington, DC: American Public Health Association, 1980, p. 503534.

BRITO, C. A. A. DE et al. Zika in Pernambuco: rewriting the first outbreak. Revista 
da Sociedade Brasileira de Medicina Tropical, v. 49, n. 5, p. 553-558, 2016.

BRONZONI, R. V. DE M. et al. Duplex Reverse Transcription-PCR Followed by Nested PCR Assays for Detection and Identification of Brazilian Alphaviruses and Flaviviruses. Journal of Clinical Microbiology, v. 43, n. 2, p. 696-702, 5 fev. 2005.

BRYANT, J. E.; BARRETT, A. D. T. Comparative phylogenies of yellow fever isolates from Peru and Brazil. FEMS Immunology and Medical Microbiology, v. 39, n. 2, p. 103-118, nov. 2003.

BRYANT, J. E.; HOLMES, E. C.; BARRETT, A. D. T. Out of Africa: A Molecular Perspective on the Introduction of Yellow Fever Virus into the Americas. PLOS Pathogens, v. 3, n. 5, p. e75, Maio 2007.

CALISHER, C. H.; GOULD, E. A. Taxonomy of the virus family Flaviviridae. Advances in virus research, v. 59, p. 1-19, 2003.

CALLAHAN, J. D. et al. Development and Evaluation of Serotype- and GroupSpecific Fluorogenic Reverse Transcriptase PCR (TaqMan) Assays for Dengue Virus. Journal of Clinical Microbiology, v. 39, n. 11, p. 4119-4124, 13 nov. 2001.

CALVET, G. et al. Detection and sequencing of Zika virus from amniotic fluid of fetuses with microcephaly in Brazil: A case study. The Lancet Infectious Diseases, p. 653-660, 2016.

CANTILE, C. et al. Pathologic and immunohistochemical findings in naturally occuring West Nile virus infection in horses. Veterinary pathology, v. 38, n. 4, p. 414-421, jul. 2001.

CAO-LORMEAU, V. M. R. E. Zika virus, French Polynesia, South Pacific, 2013. Emerging Infectious Diseases, v. 20, n. 11, p. 1960, 2014.

CARDOSO, C. W. et al. Outbreak of Exanthematous Illness Associated with Zika, Chikungunya, and Dengue Viruses, Salvador, Brazil. Emerging infectious diseases, v. 21, n. 12, p. 2274-2276. Dez. 2015.

CARDOSO, J. D. A. C. et al. Yellow fever virus in Haemagogus leucocelaenus and Aedes serratus mosquitoes, Southern Brazil, 2008. Emerging Infectious Diseases, n. 16, v.12, p. 1918-1924, 2010.

CARTER, H. R. Yellow Fever: an epidemiological and historical study of its place of origin. Baltimore: Williams \& Wilkins, 1931. 334 p.

CASSEB, A. R. et al. Seroprevalence of flaviviruses antibodies in water buffaloes (Bubalus bubalis) in Brazilian Amazon. The Journal of Venomous Animals and Toxins Including Tropical Diseases, v. 20, p. 9, 25 mar. 2014.

CAUSEY, O. R.; SHOPE, R. E.; THEILER, M. Isolation of St. Louis encephalitis virus from arthropods in Pará, Brazil. The American Journal of Tropical Medicine and Hygiene, v. 13, p. 449, 1964. 
CENTRO DE CONTROLE DE DOENÇAS E PREVENÇÃO (CDC). Fever, jaundice, and multiple organ system failure associated with 17D-derived yellow fever vaccination, 1996-2001. Morbidity and Mortality Weekly Report, n. 50, p. 643645, 2001.

CENTRO DE CONTROLE DE DOENÇAS E PREVENÇÃO (CDC). Saint Louis Encephalitis, 2016. Disponível em: <http://www.cdc.gov/sle/technical/epi.html>. Acesso em: 31 Jan. 16.

CENTRO DE CONTROLE DE DOENÇAS E PREVENÇÃO (CDC). West Nile Virus in the United States: Guidelines for Surveillance, Prevention and Control, [S.I], 2013.

CHAINTOUTIS, S. C. et al. Evaluation of a West Nile virus surveillance and early warning system in Greece, based on domestic pigeons. Comparative immunology, microbiology and infectious diseases, v. 37, n. 2, p. 131-141, mar. 2014.

CHAMBERLAIN, R. W. Epidemiology of arthropod-borne togaviruses: the role of arthropods as hosts and vectors and of vertebrate hosts in natural transmission cycles. In: SCHLESINGER, R. W. The Togaviruses: Biology, Structure, Replication. New York: Academic Press, 1980, p. 175-239.

CHAMBERS, T. J; MONATH, T. P. The Flaviviruses: Detection, Diagnosis, and Vaccine Development. Advances in Virus Research, v. 61, p. 3-577, 2003.

CHANG, G. J. et al. An integrated target sequence and signal amplification assay, reverse transcriptase-PCR-enzyme-linked immunosorbent assay, to detect and characterize flaviviruses. Journal of clinical microbiology, v. 32, n. 2, p. 477-483, fev. 1994.

CHAN, R. C. et al. Hepatitis and death following vaccination with 17D-204 yellow fever vaccine. Lancet; v. 358, p. 121-22, 2001.

CHAO, D.-Y.; DAVIS, B. S.; CHANG, G.-J. J. Development of multiplex real-time reverse transcriptase PCR assays for detecting eight medically important flaviviruses in mosquitoes. Journal of clinical microbiology, v. 45, n. 2, p. 584-589, fev. 2007.

CHASKOPOULOU, A. et al. Detection and early warning of West Nile Virus circulation in Central Macedonia, Greece, using sentinel chickens and mosquitoes. Vector borne and zoonotic diseases (Larchmont, N.Y.), v. 13, n. 10, p. 723-732, out. 2013.

CHEN, Z. et al. A fatal yellow fever virus infection in China: description and lessons. Emerging Microbes \& Infections, v. 5, n. 7, p. e69, 13 jul. 2016.

CHIU, C. Y. et al. Diagnosis of Fatal Human Case of St. Louis Encephalitis Virus Infection by Metagenomic Sequencing, California, 2016. Emerging Infectious Diseases, v. 23, n. 10, p. 1964-1968, out. 2017. 
$\mathrm{CHOI}, \mathrm{K}$. H. et al. The structure of the RNA-dependent RNA polymerase from bovine viral diarrhea virus establishes the role of GTP in de novo initiation. Proceedings of the National Academy of Sciences of the United States of America, v. 101, n. 13, p. 4425-4430, mar. 2004.

COIMBRA, T. L. et al. Iguape: a newly recognized flavivirus from Sao Paulo State, Brazil. Intervirology, v. 36, n. 3, p. 144-152, 1993.

COIMBRA, T. L.; ROCCO, I. M.; SUZUKI, A. Arthropod-and-rodent-borne detected in São Paulo State, Brazil. In: TRAVASSOS DA ROSA, A.P.A.; VASCONCELOS, P. F. C., TRAVASSOS DA ROSA J.F.S. An overview of arbovirology in Brazil and neighbouring countries. Belém, [S.I], 1998. p. 168-176.

CUI, S. et al. Detection of yellow fever virus genomes from four imported cases in China. International journal of infectious diseases, v. 60, p. 93-95, jul. 2017.

CUNHA, M. S. et al. First Complete Genome Sequence of Zika Virus (Flaviviridae, Flavivirus) from an Autochthonous Transmission in Brazil. Genome announcements, v. 4, n. 2, p. 2015-2016, 2016.

DAY, J. F. Predicting St. Louis encephalitis virus epidemics: Lessons from recent, and not so recent, outbreaks. Annual Review of Entomology, v. 46, p, 111-138, 2001.

DE FIGUEIREDO, G. G. et al. Genetic characterization of Cacipacore virus from ticks collected in Sao Paulo State, Brazil. Archives of virology, v. 162, n. 6, p. 17831786, jun. 2017.

DE PAULA FREITAS, B. et al. Ocular Findings in Infants With Microcephaly Associated With Presumed Zika Virus Congenital Infection in Salvador, Brazil. JAMA ophthalmology, fev. 2016.

DE SOUZA, R. P. et al. Detection of a new yellow fever virus lineage within the South American genotype I in Brazil. Journal of medical virology, v. 82, n. 1, p. 175-185, jan. 2010.

DIAZ, L. A. et al. Genotype III Saint Louis encephalitis virus outbreak, Argentina, 2005. Emerging infectious diseases, v. 12, n. 11, p. 1752-1754, nov. 2006.

DRIGGERS, R. W. et al. Zika Virus Infection with Prolonged Maternal Viremia and Fetal Brain Abnormalities. The New England journal of medicine, v. 22, n. 74, p. 2142-2151, 2016.

DOMINGO, C. et al. Advanced Yellow Fever Virus Genome Detection in Point-ofCare Facilities and Reference Laboratories. Journal of Clinical Microbiology, v. 50, n. 12, p. 4054-4060, dez. 2012.

DUFFY, M. et al. Zika Virus Outbreak on Yap Island, Federated States of Micronesia. New England Journal of Medicine, v. 360, p. 2536-2543, 2009.

DUPONT-ROUZEYROL, M. et al. Erratum: Infectious Zika viral particles in breastmilk 
(The Lancet (2016) 387 (1051). The Lancet, v. 387, n. 10023, p. 1056, 2016.

DYER, J.; CHISENHALL, D. M.; MORES, C. N. A multiplexed TaqMan assay for the detection of arthropod-borne flaviviruses. Journal of virological methods, v. 145, n. 1, p. 9-13, out. 2007.

EDMAN, J. D. Host-feeding patterns of Florida mosquitoes. 3. Culex (Culex) and Culex (Neoculex). Journal of Medical Entomoly, v. 11, p. 95-104, 1974.

ERLANGER, T. E. et al. Past, present, and future of Japanese encephalitis. Emerging infectious diseases, v. 15, n. 1, p. 1-7, jan. 2009.

EPSTEIN, P. R. West Nile virus and the climate. Journal of Urban Health, vol. 78, p. 367-371, 2001.

FAGBAMI, A. H. Zika virus infections in Nigeria: virological and seroepidemiological investigations in Oyo State. The Journal of Hygiene, v. 83, n. 2, 213-219, 1979.

FARIA, N. R. et al. Zika virus in the Americas: Early epidemiological and genetic findings. v. 352, n. 6283, p. 345-349, Abril 2016.

FAYE, O. et al. Molecular Evolution of Zika Virus during Its Emergence in the 20th Century. PLoS Neglected Tropical Diseases, v. 8, n. 1, p. 36, 2014.

FERREIRA, D. D. et al. Characterization of an insect-specific flavivirus (OCFVPT) coisolated from Ochlerotatus caspius collected in southern Portugal along with a putative new Negev-like virus. Virus genes, v. 47, n. 3, p. 532-545, dez. 2013.

FERREIRA, I. B. et al. Surveillance of arbovirus infections in the Atlantic Forest Region, State of São Paulo, Brazil. Detection of hemagglutination-inihibiting antibodies in wild birds between 1978 and 1990. Revista do Instituto de Medicina Tropical de São Paulo, n. 3, v. 36, p. 265-274, 1994.

FIGUEIREDO, L. T. M. et al. Identification of Brazilian flaviviruses by a simplified reverse transcription-polymerase chain reaction method using Flavivirus universal primers. The American journal of tropical medicine and hygiene, v. 59, n. 3, p. 357-362, set. 1998.

FIGUEIREDO, L. T. M. Estudo sobre infecções por arbovírus na região de Ribeirão Preto, Estado de São Paulo. Tese de doutorado, Faculdade de Medicina de Ribeirão Preto da Universidade de São Paulo, Ribeirão Preto, SP, 1985.

FIGUEIREDO L. T. M. The Brazilian flaviviruses. Microbes and Infection, n. 2, p.1643-1649, 2000.

FIGUEIREDO, M. L. G. DE et al. Cacipacore virus as an emergent mosquito-borne Flavivirus. Revista da Sociedade Brasileira de Medicina Tropical, v. 50, n. 4, p. 539-542, 2017.

FINLAY, C. J. The mosquito hypothetically considered as the agent of transmission of Yellow Fever Poison. Yale Journal of Biology and Medicine, v. 6, n. 9, p. 589604, 1937. 
FOCKS, D. A. et al. A simulation model of the epidemiology of urban dengue fever: Literature analysis, model development, preliminary validation, and samples of simulation results. American Journal of Tropical Medicine and Hygene, v. 5, n. 53, p. 489-506, 1995.

FOY, B. D. et al. Probable Non-Vector-borne Transmission of Zika Virus, Colorado, USA. Emerging Infectious Diseases, v. 17, n. 5, p. 880-882, 2011.

FRANK, D. One world, one health, one medicine. The Canadian Veterinary Journal, v. 49, n. 11, p. 1063-1065, nov. 2008.

FROST, M. J. et al. Characterization of virulent West Nile virus Kunjin strain, Australia, 2011. Emerging infectious diseases, v. 18, n. 5, p. 792-800, maio 2012. Guidelines for surveillance, prevention and control of West Nile virus.

Epidemiological bulletin, v. 23, n. 4, p. 12-14, dez. 2002.

FULOP, L. et al. Rapid identification of flaviviruses based on conserved NS5 gene sequences. Journal of virological methods, v. 44, n. 2-3, p. 179-188, out. 1993.

GARDNER, C. L.; RYMAN, K. D. Yellow Fever: A Reemerging Threat. Clinics in laboratory medicine, v. 30, n. 1, p. 237-260, mar. 2010.

GAUNT, M. W. et al. Phylogenetic relationships of flaviviruses correlate with their epidemiology, disease association and biogeography. The Journal of general virology, v. 82, n. 8, p. 1867-1876, ago. 2001.

GOMES, G.; CAUSEY, O. R. Bussuquara, A New Arthropod-Borne Virus.

Proceedings of the Society for Experimental Biology and Medicine, v. 101, n. 2, p. 275-279, jun. 1959.

GOURINAT, A. C. et al. Detection of zika virus in urine. Emerging Infectious Diseases, v. 21, n. 1, p. 84-86, 2015.

GRARD, G. et al. Genetic characterization of tick-borne flaviviruses: new insights into evolution, pathogenetic determinants and taxonomy. Virology, v. 361, n. 1, p. 80-92, abr. 2007.

GRARD, G. et al. Ngoye virus: a novel evolutionary lineage within the genus Flavivirus. The Journal of general virology, v. 87, n. Pt 11, p. 3273-3277, nov. 2006.

GRITSUN, T. S.; LASHKEVICH, V. A.; GOULD, E. A. Tick-borne encephalitis. Antiviral research, v. 57, n. 1-2, p. 129-146, jan. 2003.

GROBBELAAR, A. A. et al. Resurgence of Yellow Fever in Angola, 2015-2016.

Emerging Infectious Diseases, v. 22, n. 10, p. 1854, out. 2016.

GUBLER, D. J.; CLARK, G. G. Dengue/dengue hemorrhagic fever: the emergence of a global health problem. Emerging Infectious Diseases, v. 1, n. 2, p. 55-57, 1995. 
GUBLER, D. J. Dengue. In: The Arboviruses: Epidemiology and Ecology.

Monath, T. P. (eds), CRC Press, Boca Raton, Fla, 1988, p. 223-260.

GUBLER, D. J. The global pandemic of dengue/dengue haemorrhagic fever: current status and prospects for the future. Annals of the Academy of Medicine, Singapore, n. 2, v. 27, p. 227-234, 1998.

GUZMAN, M. G.; HARRIS, E. Dengue. The Lancet, v. 385, n. 9966, p. 453-465, 18 out. 2017.

HANNA, J. N. et al. Japanese encephalitis in north Queensland, Australia, 1998. The Medical journal of Australia, v. 170, n. 11, p. 533-536, jun. 1999.

HAYES, E. B. Zika virus outside Africa. Emerging Infectious Diseases, v. 15, n. 9, p. 1347-1350, 2009.

HADDOW, A. D. et al. First isolation of Aedes flavivirus in the Western Hemisphere and evidence of vertical transmission in the mosquito Aedes (Stegomyia) albopictus (Diptera: Culicidae). Virology, v. 440, n. 2, p. 134-139, jun. 2013.

HADDOW, A. D. et al. Genetic characterization of Zika virus strains: geographic expansion of the Asian lineage. PLoS Negl Trop Dis, v. 6, 2012.

HADDOW A. J. The natural history of yellow fever in Africa. Proceedings of the Royal Society of Edinburgh, v, 70, p. 191-227, 1968.

HALL, T. A. Bioedit: a user-friendly biological sequence aligment editor and analysis program for Windons 95/98/NT. Nucleic Acids Symposium Series, [S.I], v. 41, p. 95-98, 1999.

HARDY, J. L., REEVES, W. C. Experimental studies on infection in vectors. In: Epidemiology and control of mosquito-borne arboviruses in California, 1943-1987 (W. C. Reeves, ed.). 1990. California Mosquito Vector Control Association, Sacramento, CA, pp. 145-250.

HEANG, V. et al. Zika virus infection, Cambodia, 2010. Emerging Infectious Diseases, v. 18, n. 2, p. 349-351, 2012.

HEINEN, L. B. DA S. et al. Saint Louis Encephalitis Virus in Mato Grosso, CentralWestern Brazil. Revista do Instituto de Medicina Tropical de São Paulo, v. 57, n. 3, p. 215-20, 2015.

HEINZ, F. X.; ALLISON, S. L. Structures and mechanisms in flavivirus fusion. Advances in virus research, v. 55, p. 231-269, 2000.

HOSHINO, K. et al. Entomological surveillance for flaviviruses at migratory bird stopover sites in Hokkaido, Japan, and a new insect flavivirus detected in Aedes galloisi (Diptera: Culicidae). Journal of medical entomology, v. 49, n. 1, p. 175182, jan. 2012. 
HOWARD, C. R.; FLETCHER, N. F. Emerging virus diseases: can we ever expect the unexpected? Emerging microbes \& infections, v. 1, n. 12, p. e46, dez. 2012.

HUBALEK, Z. European experience with the West Nile virus ecology and epidemiology: Could it be relevant for the New World? Viral Immunology, v. 13, p. 415-426, 2000.

IVERSSON, L. B. Aspectos da epidemia de encefalite por arbovírus na região do vale do Ribeira, S. Paulo, Brasil, no período de 1975 a 1978. Revista de Saúde Pública, n. 14, p.9-35, 1980.

IVERSSON, L. B. Circulation of Eastern equine encephalitis, Western equine encephalitis, Ilhéus, Maguari and Tacaiuma viruses in equines of the Brazilian Pantanal, South America. Revista do Instituto de Medicina Tropical de São Paulo, n. 4, v. 35, p.355-359, 1993.

IVERSSON, L.B. Rocio encephalitis. In: MONATH, T.P. The arboviruses: epidemiology and ecology. 4 ed. Boca Raton: CRC Press, 1988, p. 77-92.

IVERSSON, L. B.; TRAVASSOS, A. P. R.; ROSA, M. D. Recent occurrence of human infection by Rocio arbovirus in the Valley of Ribeira region. Revista do Instituto de Medicina Tropical de São Paulo, n. 1, v. 31, p. 28-31, 1989.

IVERSSON, L.B.; TRAVASSOS DA ROSA, A.P.A.; TRAVASSOS DA ROSA, J. Estudos sorológicos para pesquisa de anticorpos de arbovírus em população humana da região do Vale do Ribeira. II. Inquérito em pacientes do Hospital Regional de Pariquera-Açu, 1980. Revista de Saúde Pública, v. 15, p. 587-602, 1981.

ISHII, K.; MATSUNAGA, Y.; KONO, R. Immunoglobulins produced in response to Japanese encephalitis virus infections of man. Journal of immunology, v. 101, n. 4, p. $770-775$, out. 1968.

JETTEN, T. H.; FOCKS, D. A. Potential changes in the distribution of dengue transmission under climate warming. American Journal of Tropical Medicine Hygiene, v. 57, p. 285-297, 1997.

JOHANSSON, M. A.; VASCONCELOS, P. F. C.; STAPLES, J. E. The whole iceberg: estimating the incidence of yellow fever virus infection from the number of severe cases. Transactions of the Royal Society of Tropical Medicine and Hygiene, v. 108, n. 8, p. 482-487, ago. 2014.

JOHNSON, B. W. et al. Ilheus virus isolate from a human, Ecuador. Emerging Infectious Diseases, n. 6, v. 13, p. 956-958, 2007.

JOHNSON, B. W.; RUSSELL, B. J.; LANCIOTTI, R. S. Serotype-specific detection of dengue viruses in a fourplex real-time reverse transcriptase PCR assay. Journal of clinical microbiology, v. 43, n. 10, p. 4977-4983, out. 2005. 
JOHNSON, N. et al. Assessment of a novel real-time pan-flavivirus RT-polymerase chain reaction. Vector borne and zoonotic diseases, v. 10, n. 7, p. 665-671, out. 2010.

JOSEPH, S. et al. First isolation of West Nile virus from a dromedary camel. Emerging Microbes \& Infections, v. 5, n. 6, p. e53, 8 jun. 2016

KARLIN, S.; ALTSCHUL, S. F. Methods for assessing the statistical significance of molecular sequence features by using general scoring schemes. Proceedings of the National Academy of Sciences of the United States of America, v. 87, n. 6, p. 2264-2268, mar. 1990.

KASSAVETIS, P. et al. Zika virus-associated Guillain-Barré syndrome variant in Haiti. Neurology, [S.I], maio 2016.

KENNEY, J. L. et al. Characterization of a novel insect-specific flavivirus from Brazil: potential for inhibition of infection of arthropod cells with medically important flaviviruses. The Journal of general virology, v. 95, n. 12, p. 2796-2808, dez. 2014.

KENT, R. J.; CRABTREE, M. B.; MILLER, B. R. Transmission of West Nile virus by Culex quinquefasciatus say infected with Culex Flavivirus Izabal. PLoS neglected tropical diseases, v. 4, n. 5, p. e671, maio 2010.

KING, A. M. Q.; ADAMS, M. J.; CARSTENS, E. B.; LEFKOWITZ, E. J. 2012. Virus Taxonomy: Ninth report of the international Committee on Taxonomy of Viruses (ICTV). San Diego: Elsevier Academic Press, p. 1327.

KOLODZIEJEK, J. et al. Barkedji virus, a novel mosquito-borne flavivirus identified in Culex perexiguus mosquitoes, Israel, 2011. The Journal of general virology, v. 94, n. Pt 11, p. 2449-2457, nov. 2013.

KRAEMER, M. U. G. et al. Spread of yellow fever virus outbreak in Angola and the Democratic Republic of the Congo 2015-16: a modelling study. The Lancet. Infectious diseases, v. 17, n. 3, p. 330-338, mar. 2017.

KRAMER, L. D.; CHANDLER, L. J. Phylogenetic analysis of the envelope gene of St. Louis encephalitis virus. Archives of virology, v. 146, n. 12, p. 2341-2355, dez. 2001.

KRAMER, L. D.; CHANDLER, L. J. Phylogenetic analysis of the envelope gene of St. Louis encephalitis virus. Archives of Virology, n. 12, v. 146, p. 2341-2355, dez. 2001.

KRAMER, L. D.; EBEL, G. D. Dynamics of Flavivirus Infection in Mosquitoes. Advances in Virus Research, v. 60, p. 187-232, 2003.

KUMAR S., STECHER, G., TAMURA, K. Mega 7: Molecular Evolutionary Genetics version 7 for bigger datasets. Molecular Biology and Evolution, v. 33, p. 18701874. 
KUNO, G.; CHANG, G. J. J. Biological transmission of arboviruses: reexamination of and new insights into components, mechanisms, and unique traits as well as their evolutionary trends. Clinical microbiology reviews, v. 18, n. 4, p. 608-637, out. 2005.

KUNO, G. Serodiagnosis of flaviviral infections and vaccinations in humans. Advances in virus research, v. 61, p. 3-65, 2003.

KUNO, G. et al. Phylogeny of the genus Flavivirus. Journal of Virology, v. 72, n. 1, p. 73-83, 1998a.

KUNO G. Universal diagnostic RT-PCR protocol for arboviruses. Journal of Virological Methods, $n$. 1 , v. 72 , p. 27-41, 1998b.

KUTSUNA, S. et al. Two cases of zika fever imported from french polynesia to Japan, December to January 2013. Eurosurveillance : bulletin Europeen sur les maladies transmissibles - European communicable disease bulletin v. 19, n. 4, p. 1-4, 2014.

LAEMMERT, H. W.; HUGHES, T. P. The virus of Ilheus encephalitis. Isolation, serological specificity, and transmission. Journal of Immunology, n. 1, v. 55, p. 61$67,1947$.

LANCIOTTI, R. S. Molecular amplification assays for the detection of flaviviruses. Adv Virus Res, v. 61, 2003.

LANCIOTTI, R. S. et al. Genetic and serologic properties of Zika virus associated with an epidemic, Yap State, Micronesia, 2007. Emerging Infectious Diseases, v. 14, n. 8, p. 1232-1239, 2008.

LANCIOTTI, R. S. et al. Origin of the West Nile virus responsible for an outbreak of encephalitis in the northeastern United States. Science (New York, N.Y.), v. 286, n. 5448, p. 2333-2337, dez. 1999.

LANCIOTTI, R. S. et al. Rapid detection of west nile virus from human clinical specimens, field-collected mosquitoes, and avian samples by a TaqMan reverse transcriptase-PCR assay. Journal of clinical microbiology, v. 38, n. 11, p. 40664071, nov. 2000.

LEDERMANN, J. P. et al. Aedes hensilli as a Potential Vector of Chikungunya and Zika Viruses. PLoS Neglected Tropical Diseases, v. 8, n. 10, 2014.

LINDENBACH, B. D.; THIEL, H. J.; RICE, C. M. Flaviviridae: The Viruses and Their Replication. In: KNIPE, D.M.; HOWLEY, P.M. Field's Virology. 5 ed. Philadelphia: Lippincott, Williams \& Wilkins, 2007, p. 1102-1152.

LINDSEY, N. P.; SCHROEDER, B. A.; MILLER, E. R. Adverse event reports following yellow fever vaccination. Vaccine, v. 26, p. 6077-6082, 2008.

LIKOS, A. et al. Local Mosquito-Borne Transmission of Zika Virus - Miami-Dade and Broward Counties, Florida, June-August 2016. MMWR. Morbidity and mortality 
weekly report, v. 65, n. 38, p. 1032-1038, set. 2016.

LOPES, O. S.; COIMBRA, T.L.M.; SACCHETTA, L.A.; CALISHER, C. H. Emergence of a new arbovirus disease in Brazil. I. Isolation and characterization of the etiologic agent, Rocio virus. American Journal of Epidemiology, v. 107, p. 444- 449, 1978a.

LOPES, O. S.; DE ABREU SACCHETTA, L.; COIMBRA, T. L. M.; PEREIRA, L. E. Isolation of St. Louis encephalitis virus in South Brazil. The American Journal of Tropical Medicine and Hygiene, v. 28, p. 583-585, 1979.

LOPES, O. S.; SACCHETTA, L. A.; COIMBRA, T. L. M.; GERALDO, H. P.; GLASSER, C. M. Emergence of a new arbovirus disease in Brazil. II. Epidemiological studies on 1975 epidemic. American Journal of Epidemiology, n. 5, v. 108, p. 394-401, 1978b.

LOPES, O. S.; SACCHETTA, L. A.; FRANCY, D. B.; JAKOB, W.; CALISHER, C. H. Emergence of a new arbovirus disease in Brazil. III - Isolation of Rocio virus from Psorophora ferox (Humboldt, 1819). American Journal of Epidemiology, n. 2, v. 113; p. 122-125, 1981.

LUMSDEN, L. L. St. Louis encephalitis in 1933. Observations on epidemiological features. Public Health Reports, v. 73, p. 340-353, 1958.

LUSTIG, Y. et al. Detection of Zika virus RNA in whole blood of imported Zika virus disease cases up to 2 months after symptom onset, Israel, December 2015 to April 2016. Euro surveillance : bulletin Europeen sur les maladies transmissibles European communicable disease bulletin, v. 21, n. 26, jun. 2016.

MACKENZIE, J. S.; GUBLER, D. J.; PETERSEN, L. R. Emerging flaviviruses: the spread and resurgence of Japanese encephalitis, West Nile and dengue viruses. Nature Medicine, v. 10, p. 98-109, nov. 2004.

MARCANTONIO, M. et al. Identifying the environmental conditions favouring West Nile Virus outbreaks in Europe. PloS one, v. 10, n. 3, p. e0121158, 2015.

MARTIN, M.; TSAI, T. F.; CROPP, B. Fever and multisystem organ failure associated with 17D-204 yellow fever vaccination: a report of four cases. Lancet, v. 358, p. 98104, 2001.

MCLEAN, R. G.; BOWEN, G. S. Vertebrate hosts. In "St. Louis encephalitis" (T. P. Monath, ed.), 1980. American Public Health Association, Washington, DC, pp. 381450.

MCLEAN, R. G.; SCOTT, W. Avian Hosts Of St. Loius Encephalitis Virus Bird Control Seminars Proceedings, [S.I], 1979.

METSKY, H. C. et al. Zika virus evolution and spread in the Americas. Nature, v. 546, n. 7658, p. 411-415, jun. 2017.

MIR, D. et al. Phylodynamics of Yellow Fever Virus in the Americas: new insights into the origin of the 2017 Brazilian outbreak. Scientific reports, v. 7, n. 1, p. 7385, ago. 
2017.

MLAKAR, J. et al. Zika Virus Associated with Microcephaly. The New England journal of medicine, v. 374, n. 10, p. 951-8, 2016.

MONATH, T. P.; BALLINGER, M. E.; MILLER, B. R.; SALAUN, J. J. Detection of yellow fever viral RNA by nucleic acid hybridization and viral antigen by immunocytochemistry in fixed human liver. American Journal of Tropical Medicine and Hygiene, n. 6, v. 40, p. 663-668, 1989.

MONATH, T. P.; CETRON, M. S. Prevention of yellow fever in persons traveling to the tropics. Clinical Infectious Diseases, v. 34, p. 1369-78, 2002.

MONATH, T. P. Epidemiology. In "St. Louis Encephalitis" (T. P. Monath, ed.), 1980, pp. 239-312. American Public Health Association, Washington, DC.

MONATH, T. P. et al. Yellow fever 17D vaccine safety and immunogenicity in the elderly. Human vaccines, v. 1, n. 5, p. 207-214, 2005.

MONATH, T. P. et al. Yellow fever vaccine supply: a possible solution. The Lancet, v. 387, n. 10028, p. 1599-1600, 9 ago. 2017.

MONATH, T. P.; VASCONCELOS, P. F. C. Yellow fever. Journal of clinical virology, v. 64, p. 160-173, mar. 2015.

MONATH, T. P. Yellow fever: an update. Lancet Infectious Diseases, n.1, v.1, p.1120, 2001.

MORENO, E. S. et al. Reemergence of yellow fever: detection of transmission in the State of Sao Paulo, Brazil, 2008. Revista da Sociedade Brasileira de Medicina Tropical, v. 44, n. 3, p. 290-296, 2011.

MONDINI, A. et Simultaneous infection by DENV-3 and SLEV in Brazil. Journal of Clinical Virology, n. 1, v. 40, p. 84-86, 2007a.

MONDINI, A. et al. Saint Louis encephalitis virus. Brazilian Emerging Infectious Diseases, n. 1, v. 13, p. 176-8, Jan. 2007b.

MOUREAU, G. et al. A real-time RT-PCR method for the universal detection and identification of flaviviruses. Vector borne and zoonotic diseases, v. 7, n. 4, p. 467-477, 2007.

MOUREAU, G. et al. New Insights into Flavivirus Evolution, Taxonomy and Biogeographic History, Extended by Analysis of Canonical and Alternative Coding Sequences. PLoS ONE, v. 10, n. 2, p. e0117849, fev. 2015.

Muckenfuss, R. S.; Armstrong, C.; Webster, L. T. Etiology of the 1933 epidemic of encephalitis. JAMA, v. 103, p. 731-733, 1934.

MUSSO, D. et al. Potenial sexual transmission of Zika virus. Emerging infectious 
diseases, v. 21, n. 2, p. 359-361, 2015a.

MUSSO, D. et al. Detection of Zika virus in saliva. Journal of clinical virology : the official publication of the Pan American Society for Clinical Virology, v. 68, n. 1, p. 53-5, 2015b.

MUSSO, D.; NILLES, E. J.; CAO-LORMEAU, V. M. Rapid spread of emerging Zika virus in the Pacific area. Clinical Microbiology and Infection, v. 20, n. 10, p. 595596, 2014.

NASCI, R. S. et al. Comparison of vero cell plaque assay, TaqMan reverse transcriptase polymerase chain reaction RNA assay, and VecTest antigen assay for detection of West Nile virus in field-collected mosquitoes. Journal of the American Mosquito Control Association, v. 18, n. 4, p. 294-300, dez. 2002.

Nassar, E.S. et al. Human disease caused by an arbovirus closely related to Ilheus virus: report of five cases. Intervirology, v. 40, p. 247-252, 1997.

NUNES, M. R. T. et al. Genomic and Phylogenetic Characterization of Brazilian Yellow Fever Virus Strains. Journal of Virology, v. 86, n. 24, p. 13263-13271, dez. 2012.

OEHLER, E. et al. Zika virus infection complicated by Guillain-Barre syndrome--case report, French Polynesia, December 2013. Euro surveillance : bulletin Européen sur les maladies transmissibles - European communicable disease bulletin, v. 19, n. 9, p. 7-9, 2014.

OLIVEIRA, W. K. DE et al. Increase in reported prevalence of microcephaly in infants born to women living in areas with confirmed Zika virus transmission during the first trimester of pregnancy - Brazil , 2015. Morbidity and Mortality Weekly Report, v. 65, n. 9, p. 242-247, 2016.

OLSON, J. G., et al. Zika virus, a cause of fever in Central Java, Indonesia. Transactions of the Royal Society of Tropical Medicine and Hygiene, v. 75 , n. 3, p. 389-393, 1981.

OSÓRIO, H. C. et al. Mosquito Surveillance for Prevention and Control of Emerging Mosquito-Borne Diseases in Portugal - 2008-2014. International Journal of Environmental Research and Public Health, v. 11, n. 11, p. 11583-11596, 12 nov. 2014.

ORGANIZAÇÃO MUNDIAL DE SAÚDE (OMS). Yellow fever, 1998-1999. Weekly Epidemiological Record 2000, n. 40, v. 75, p. 322-328, 2000.

ORGANIZAÇÃO PAN-AMERICANA DE SAÚDE (OPAS), 2017. Disponível em $<$ http://www.paho.org/hq/index.php?option=com_content\&view=article\&id=11599:regi onal-zika-epidemiological-update-americas\&ltemid=41691 >. Acesso em 27.09.17

PAPA, A. et al. Detection of West Nile virus and insect-specific flavivirus RNA in Culex mosquitoes, central Macedonia, Greece. Transactions of the Royal Society of Tropical Medicine and Hygiene, v. 108, n. 9, p. 555-559, set. 2014. 
PATEL, P. et al. Development of one-step quantitative reverse transcription PCR for the rapid detection of flaviviruses. Virology Journal, v. 10, n. 1, p. 58, 2013.

PAUVOLID-CORREA, A. et al. Ilheus Virus Isolation in the Pantanal, West-Central Brazil. PLoS Neglected Tropical Diseases, n. 7, v. 7, 2013.

PAUVOLID-CORRÊA, A. et al. Nhumirim virus, a novel flavivirus isolated from mosquitoes from the Pantanal, Brazil. Archives of virology, v. 160, n. 1, p. 21-27, 25 jan. 2015.

PAUVOLID-CORREA, A. et al. Serologic evidence of the recent circulation of Saint Louis encephalitis virus and high prevalence of equine encephalitis viruses in horses in the Nhecolandia sub-region in South Pantanal, Central-West Brazil. Memórias do Instituto Oswaldo Cruz; v. 105, p. 829-833, 2010.

PELLISSIER, A. Serological investigation on the incidence of neurotropic viruses in French Equatorial Africa. Bulletin de la Societè de Pathologique Exotique et de ses Filiales, v. 47, n. 2, p. 223-227, 1954.

PEREIRA, L. E. et al. Arbovírus Ilheus em aves silvestres (Sporophila caerulescens e Molothrus bonariensis). Revista de Saúde Pública, n. 2, v. 35, p. 119-123, 2001.

PETERSEN, L. R.; MARFIN, A. A. Shifting epidemiology of Flaviviridae. Journal of travel medicine, v. 12 Suppl 1, p. S3-11, abr. 2005.

PHILIP SAMUEL, P.; TYAGI, B. K. Diagnostic methods for detection \& isolation of dengue viruses from vector mosquitoes. The Indian Journal of Medical Research, v. 123 , n. 5, p. 615-628, maio 2006.

PRIAS-LANDINEZ, E.; BERNAL-CUBIDES, C.; MORALES-ALARCON, A. Isolation of Ilheus virus from a man in Colombia. American Journal of Tropical Medicine and Hygiene, v. 17, p. 112-114, 1968.

PYBUS, O. G. et al. New inferences from tree shape: numbers of missing taxa and population growth rates. Systematic biology, v. 51, n. 6, p. 881-888, dez. 2002.

RAWLINS, S. C.; HULL, B.; CHADEE, D. D.; MARTINEZ, R.; LEMAITRE, A.; JAMES, F.; WEBB, L. Sylvatic yellow fever activity in Trinidad, 1988-1989.

Transactions of the Royal Society of Tropical Medicine and Hygiene, n. 1, v. 84, p. 142-143, 1990.

REED, L.J.; MUENCH, H. A simple method of estimating fifty percent endpoints. The American Journal of Hygiene, v. 27, p. 493-497, 1938.

REED, W.; CARROLL, J.; AGRAMONTE, A. Experimental yellow fever. American Medicine, n. 1, v. 2, p. 15-23. 1901.

REISEN, W. K.; PRESSER, S. B.; LIN, J.; ENGE, B.; HARDY, J. L.; EMMONS, R. W. Viremia and serological responses in adult chickens infected with western equine 
encephalomyelitis and St. Louis encephalitis viruses. Journal of the American Mosquito Control Association, v. 10, p. 549-555, 1994.

REISEN, W. K. Epidemiology of St. Louis encephalitis virus. Advances in Virus Research, v. 61, p. 139-183, 2003.

REISEN, W. K.; MEYER, R. P.; PRESSER, S. B.; HARDY, J. L. Effect of temperature on the transmission of western equine encephalomyelitis and St. Louis encephalitis viruses by Culex tarsalis (Diptera: Culicadae). Journal of Medical Entomology, v. 30, p. 151-160, 1993.

REISEN, W. K.; REEVES, W. C. Bionomics and ecology of Culex tarsalis and other potential mosquito vector species. In "Epidemiology and control of mosquito- borne arboviruses in California, 1943-1987" (W. C. Reeves, ed.), 1990. California Mosquito and Vector Control Assoc., Sacramento, California, pp. 254-329.

ROCCO, I. M. et. al. St. Louis encephalitis virus: first isolation from a human in São Paulo State, Brazil. Revista do Instituto de Medicina Tropical, n. 5, v. 47, p. 281 285, 2005

RODANICHE, E.; GALINDO, P. Isolation of llheus virus from Sabethes chloropterus captured in Guatemala in 1956. American Journal of Tropical Medicine and Hygiene, v. 6, p. 686-687, 1957a.

RODANICHE, E.; GALINDO, P. Isolation of the virus of Ilheus encephalitis from mosquitoes captured in Panama. American Journal of Tropical Medicine and Hygiene, v. 10, p. 393-394, 1961.

RODANICHE, E.; GALINDO, P. Isolation of yellow fever virus from Haemagogus mesodentatus, $H$. equinus and Sabethes chloropterus captured in Guatemala in 1956. The American Journal of Tropical Medicine and Hygiene, n. 6 v. 2, p. $232-$ 237, 1957b.

RODANICHE, E.; GALINDO, P.; JOHNSON, C. M. Isolation of yellow fever virus from Haemagogus lucifer, $H$. equinus, $H$. spegazzinii falco, Sabethes chloropterus and Anopheles neivai captured in Panama in the fall of 1956. The American Journal of Tropical Medicine and Hygiene, n. 6 v. 4, p. 681-685, 1957.

RODRIGUES, S. G. et al. Molecular epidemiology of Saint Louis encephalitis virus in the Brazilian Amazon: genetic divergence and dispersal. The Journal of General Virology, v. 91, n. 10, p. 2420-2427, out. 2010.

ROSA, J.F.S.T. et al. Arboviruses isolated in the Evandro Chagas Institute, including some described for the first time in the Brazilian Amazon region, their known hosts, and their pathology for man. In: TRAVASSOS DA ROSA, A. P. A., VASCONCELOS, P.F.C., ROSA, J.F.S.T. An overview of arbovirology on Brazil and neighboring countries. [S.I], Belem, 1998. p. 19-31.

ROSA, R. et al. Isolation of saint louis encephalitis virus from a horse with neurological disease in Brazil. PLoS neglected tropical diseases, v. 7, n. 11, p. 
e2537, nov. 2013.

SARNO, M. et al. Zika Virus Infection and Stillbirths: A Case of Hydrops Fetalis, Hydranencephaly and Fetal Demise. PLoS Neglected Tropical Diseases, v. 10, n. 2, p. 5-9, 2016.

SAVAGE, H. M. et al. Entomologic and avian investigations of an epidemic of West Nile fever in Romania in 1996, with serologic and molecular characterization of a virus isolate from mosquitoes. The American journal of tropical medicine and hygiene, v. 61, n. 4, p. 600-611, out. 1999.

SCARAMOZZINO, N. et al. Comparison of flavivirus universal primer pairs and development of a rapid, highly sensitive heminested reverse transcription-PCR assay for detection of flaviviruses targeted to a conserved region of the NS5 gene sequences. Journal of clinical microbiology, v. 39, n. 5, p. 1922-1927, maio 2001.

SHAFFER, L. E. Role of surveillance in disease prevention and control: Crossspecies surveillance contribution to one medicine. Conference Notes: AVMA Annual Meeting, [S.I], 2008.

SCHULER-FACCINI, L. et al. Possible association between Zika virus infection and microcephaly-Brazil, 2015. Morbidity and Mortality Weekly Report, v. 65, n. 3, p. 59-62, 2016.

SHANNON, R. C.; WHITMAN, L.; FRANCA, M. Yellow Fever Virus in Jungle Mosquitoes. Science, n. 88, v. 2274, p. 110-111, 1938.

SHEN, S. et al. Phylogenetic analysis revealed the central roles of two African countries in the evolution and worldwide spread of Zika virus. Virologica Sinica, v. 31, n. 2, p. 118-130, abr. 2016.

SHI, P. Y. et al. High-throughput detection of West Nile virus RNA. Journal of clinical microbiology, v. 39, n. 4, p. 1264-1271, abr. 2001.

SHOPE, R. E. Epidemiology of other arthropod-borne flaviviruses infecting humans. Advances in virus research, v. 61, p. 373-391, 2003.

SIMPSON, D. I. Zika virus infection in man. Transactions of the Royal Society of Tropical Medicine and Hygiene, v. 68, p. 335-338, 1964.

SOPER, F. L. et al. Yellow fever without Aedes aegypti: study of a rural epidmic in the Valle do Chanaan, Espirito Santo, Brazil, 1932. American Journal of Tropical Medicine Hygiene, v. 18, p. 555-87, 1933.

SOPER, F. L. Yellow fever. In: Taylor, B. Z., editor. Clinical tropical medicine. New York City: Paul B Hoeber; 1944. p. 391-420.

SIMMONDS, P. et al. ICTV Virus Taxonomy Profile: Flaviviridae. The Journal of General Virology, v. 98, n. 1, p. 2-3, 17 jan. 2017. 
SRIHONGSE, S.; JOHNSON, C. M. The first isolation of Bussuquara virus from man. Transactions of the Royal Society of Tropical Medicine and Hygiene, $v$. 65, n. 4, p. 541-542, 1971.

SRIHONGSE, S.; JOHNSON, C. M. The isolation of Ilheus virus from a man in Panama. American Journal of Tropical Medicine Hygiene, v. 16, p. 516-8, 1967.

STAPLES, J. E. et al. Yellow Fever Vaccine Booster Doses: Recommendations of the Advisory Committee on Immunization Practices, 2015. MMWR. Morbidity and mortality weekly report, v. 64, n. 23, p. 647-650, jun. 2015.

STAPLES, J. E.; MONATH, T. P. Yellow fever: 100 years of discovery. JAMA, v. 300, n. 8, p. 960-962, ago. 2008.

STOLLAR, V.; THOMAS, V. L. An agent in the Aedes aegypti cell line (Peleg) which causes fusion of Aedes albopictus cells. Virology, v. 64, n. 2, p. 367-377, abr. 1975.

STRAATMANN, A.; SANTOS-TORRES, S.; VASCONCELOS P. F. C.; TRAVASSOS DA ROSA, A. P. A.; RODRIGUES, S. G.; TAVARES-NETO, J. Evidências sorológicas da circulação do arbovírus Rocio (Flaviviridae) na Bahia. Revista da Sociedade Brasileira de Medicina Tropical, n. 6, v. 30, p. 511-515, 1997.

STRODE, G.K. Yellow Fever. New York: McGraw-Hill Book Co., 1951.

STUART, G. The Problem of Mass Vaccination Against Yellow Fever. World Health Organization, p. 1-13, 1953.

SULKIN, S. E., ALLEN, R.; MIURA, T.; TOYOKA,W. Studies of arthropod-borne virus infections in Chiroptera. VI. Isolation of Japanese B encephalitis virus from naturally infected bats. American Journal of Tropical Medicine Hygiene, v. 19, p. 77-87, 1970.

SVOBODA et. al. Serological evidence for Saint Louis encephalitis virus in freeranging New World monkeys and horses within the upper Paraná River basin region, Southern Brazil. Revista da Sociedade Brasileira de Medicina Tropical, v. 47, n. 3, p. 280-286, 2014.

TANAKA, M. Rapid identification of flavivirus using the polymerase chain reaction. Journal of virological methods, v. 41, n. 3, p. 311-322, mar. 1993.

TAVARES-NETO, J. et al. Pesquisa de anticorpos para arbovírus no soro de residentes no Povoado de Corte de Pedra, Valença, Bahia. Memórias do Instituto Oswaldo Cruz, v. 8, p. 351-358, 1986.

TAYLOR, R. M. Epidemiology. In: Yellow Fever. Strode, G. K. (eds), McGraw-Hill, New York, 1951, p. 431-538.

TEIXEIRA, L. A. Da transmissão hídrica a culicidiana: a febre amarela na sociedade de medicina e cirurgia de São Paulo. Revista Brasileira de História, São Paulo, v. 21, n. 41, p. 217-242, 2001. 
TEMPELIS, C. H. Host-feeding patterns of mosquitoes, with a review of advances in analysis of blood meals by serology. Journal of Medical Entomology, v. 11, p. 635653, 1975.

THEILER, M.; SMITH, H. H. The effect of prolonged cultivation in vitro upon the pathogenicity of Yellow Fever virus. The Journal of Experimental Medicine, v. 65, n. 6, p. 767-786, maio 1937a.

THEILER, M.; SMITH, H. H. The use of Yellow Fever virus modified by in vitro cultivation for human immunization. The Journal of Experimental Medicine, v. 65, n. 6 , p. $787-800$, maio $1937 b$.

THOMAS, D. L. et al. Local Transmission of Zika Virus--Puerto Rico, November 23, 2015-January 28, 2016. MMWR. Morbidity and mortality weekly report, v. 65, n. 6, p. 154-158, fev. 2016.

TOMLINSON, W.; HODGSON, R. S. Centennial year of yellow fever eradication in New Orleans and the United States, 1905-2005. The Journal of the Louisiana State Medical Society : official organ of the Louisiana State Medical Society, v. 157, n. 4, p. 216-217, 2005.

TRAVASSOS DA ROSA, A. P. A.; VASCONCELOS P. F .C.; PINHEIRO, F. P, SHOPE, R. E.; TRAVASSOS DA ROSA, J. F.S.; RODRIGUES, S. G.; DÉGALIER, N.; TRAVASSOS DA ROSA E. Arboviruses pathogenic for man in Brazil. In:

TRAVASSOS DA ROSA, A.P.A.; VASCONCELOS, P. F. C., TRAVASSOS DA ROSA J.F.S. An overview of arbovirology in Brazil and neighbouring countries. Belém, [S.I], 1998, p. 72-104.

TROILLET, N.; LAURENCET, F. Effects of yellow fever vaccination. Lancet; v. 358, p. 1908-1909, 2001.

TSAI, T. F.; MITCHELL, C. J. St. Louis encephalitis. In: MONATH, T. P. The arboviruses: epidemiology and ecology. Florida: CRC Press, Boca Raton, 1989. p. 431-458.

TURELL, M. J. et al. An update on the potential of North American mosquitoes (Diptera: Culicidae) to transmit West Nile virus. Journal of Medical Entomology, v. 42, p. 57-62, 2005.

TURELL, M. J. et al. Isolation of viruses from mosquitoes (Diptera: Culicidae) collected in the Amazon Basin region of Peru. Journal of Medical Entomology, $n$. 5, v. 42, p. 891-898, 2005.

VAINIO, J., CUTTS, F. Yellow fever. Weekly Epidemiological Record, v. 78, p. 349-359, 1998.

VAN HANDEL, E. et al. C. Plant sugar, glycogen, and lipid assay of Aedes aegypti collected in urban Puerto Rico and rural Florida. Journal of American Mosquito Control Association, v. 10, p. 149-153, 1994. 
VASCONCELOS, P. F. et al. An epidemic of sylvatic yellow fever in the southeast region of Maranhao State, Brazil, 1993-1994: epidemiologic and entomologic findings. The American journal of tropical medicine and hygiene, v. 57, n. 2, p. 132-137, ago. 1997.

VASCONCELOS, P. F. C. et al. Arboviruses pathogenic for man in Brazil. In: ROSA A. P. A. T.; VASCONCELOS, P. F. C., ROSA, J. F. S. T. (eds) An overview of arbovirology in Brazil and neighbouring countries, Instituto Evandro Chagas, Belém, p.72-79, 1998.

VASCONCELOS, P. F. C. Febre amarela. Revista da Sociedade Brasileira de Medicina Tropical, n. 2, v. 36, p. 275-293, 2003.

VASCONCELOS, P. F. C. et al. Arboviroses. In: Tratado de infectologia, vol. 1. Focaccia, R.; Veronesi, R. (eds)., São Paulo, Brasil, Atheneu, 2005, p. 289-302.

VASCONCELOS, P. F. et al. Isolations of yellow fever virus from Haemagogus leucocelaenus in Rio Grande do Sul State, Brazil. Transactions of the Royal Society of Tropical Medicine and Hygiene, v. 97, n. 1, p. 60-62, 2003.

VASCONCELOS, P. F. C. et al. Genetic Divergence and Dispersal of Yellow Fever Virus, Brazil. Emerging Infectious Diseases, v. 10, n. 9, p. 1578-1584, set. 2004.

VENEGAS, E. A.; AQUILAR P. V.; CRUZ, C. GUEVARA, C.; KOCHEL, T. J.; VARGAS, J.; HALSEY, E. S. Ilheus Virus Infection in Human, Bolivia. Emerging Infectious Diseases, v. 18, n. 3, p. 516-518, mar. 2012.

VENTER, M. et al. Lineage 2 west nile virus as cause of fatal neurologic disease in horses, South Africa. Emerg Infect Dis, v. 15, 2009.

WEBSTER, L. T.; FITE, G. L. Contribution to the etiology of encephalitis. Differentiation of encephalitis by protection tests. Proceedings of the Society for Experimental Biology and Medicine, v. 31, p. 344-346, 1933.

WERFEL, U., POPP, W. Effects of yellow fever vaccination. Lancet, v. 358, n. 1, p. 1909, 2001.

WILDER-SMITH, A. et al. Epidemic arboviral diseases: priorities for research and public health. The Lancet Infectious Diseases, v. 17, n. 3, p. e101-e106, 9 ago. 2017.

WOUTHUYZEN-BAKKER, M.; KNOESTER, M.; VAN DEN BERG, A. P.; et al. Yellow fever in a traveller returning from Suriname to the Netherlands, March 2017. Eurosurveillance, v. 22, n. 11, p. 30488, 2017.

YANG, C. F. et al. Screening of mosquitoes using SYBR Green I-based real-time RTPCR with group-specific primers for detection of Flaviviruses and Alphaviruses in Taiwan. Journal of virological methods, v. 168, n. 1-2, p. 147-151, set. 2010. 
ZANLUCA, C. et al. First report of autochthonous transmission of Zika virus in Brazil. Memorias do Instituto Oswaldo Cruz, v. 110, n. 4, p. 569-572, 2015.

ZIEGLER, U. et al. Epidemic Spread of Usutu Virus in Southwest Germany in 2011 to 2013 and Monitoring of Wild Birds for Usutu and West Nile Viruses. Vector borne and zoonotic diseases (Larchmont, N.Y.), v. 15, n. 8, p. 481-488, ago. 2015.

ZUO, S. et al. Detection of Quang Binh virus from mosquitoes in China. Virus research, v. 180, p. 31-38, fev. 2014. 


\section{ANEXOS}




\section{First Complete Genome Sequence of Zika Virus (Flaviviridae, Flavivirus) from an Autochthonous Transmission in Brazil}

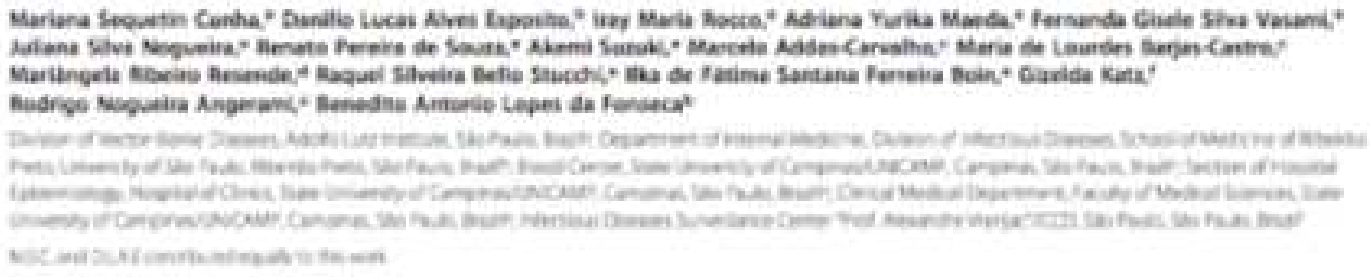

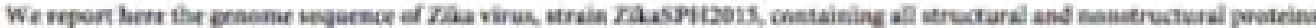

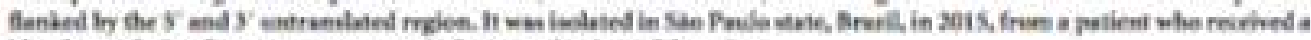

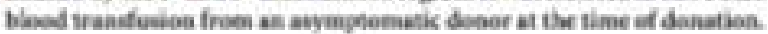

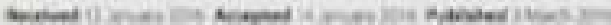

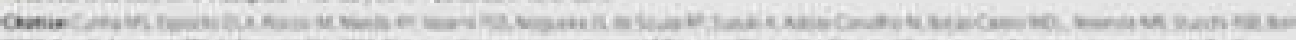

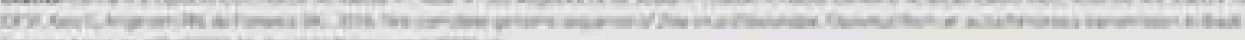

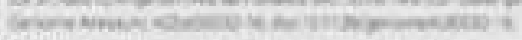

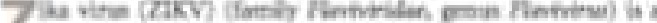

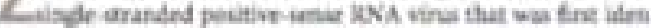

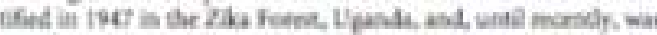

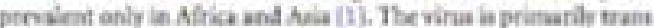

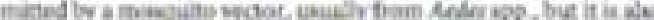

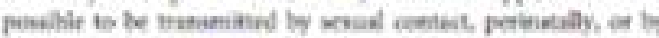

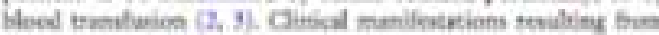

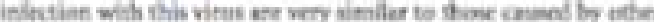

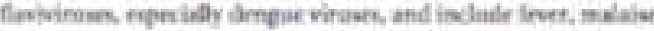

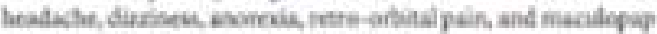

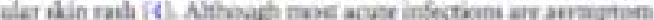

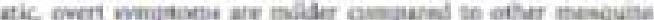

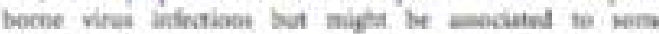

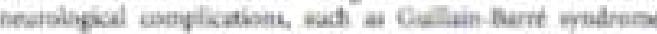

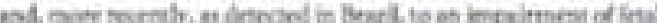

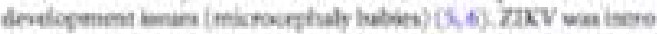

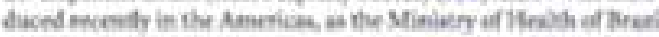

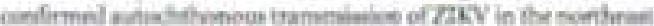

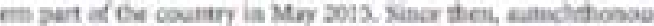

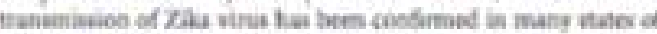

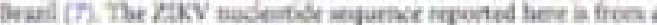

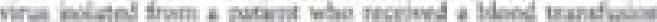

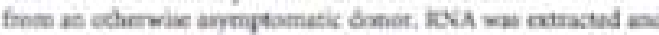

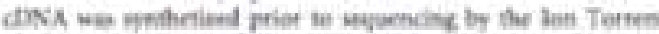

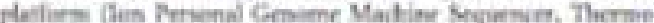

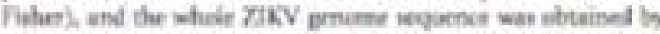

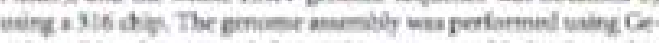

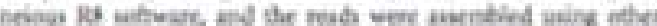

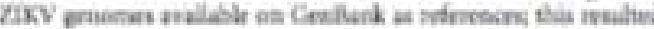

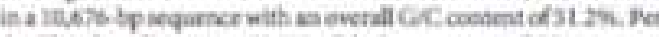

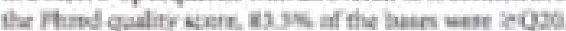

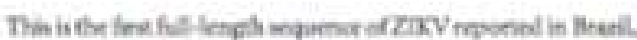

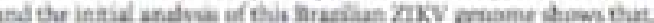

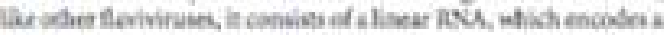

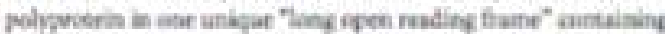

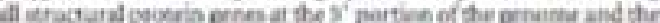

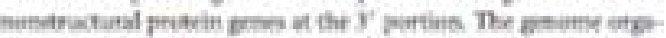

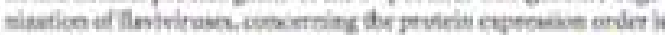

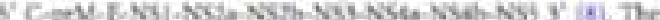

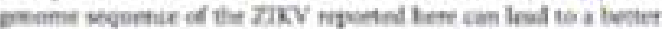

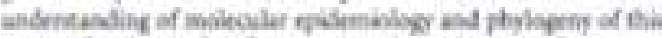

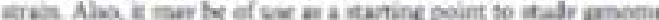

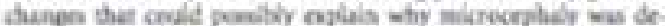

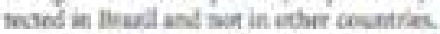

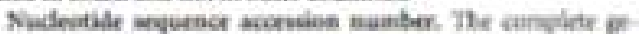

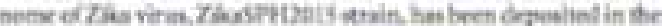

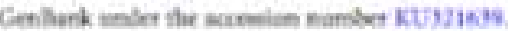

\section{ruwbuve inroamanow}

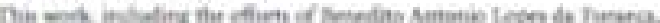

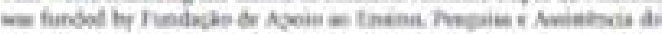

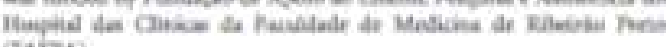
$00 \%$.

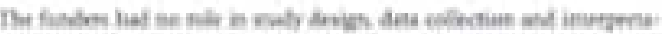

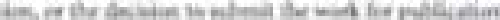

\section{efreatincts}

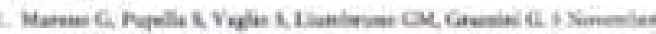

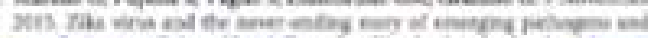

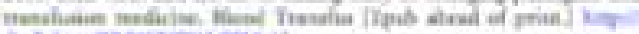

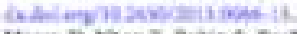

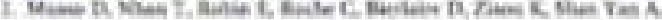

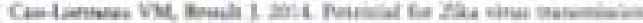


through blood transfusion demonstrated during an outbreak in French Polynesia, November 2013 to February 2014. Euro Surveill 19:20761. http://dx.doi.org/10.2807/1560-7917.ES2014.19.14.20761.

3. Musso D, Roche C, Robin E, Nhan T, Teissier A, Cao-Lormeau VM. 2015. Potential sexual transmission of Zika virus. Emerg Infect Dis 21: 359-361. http://dx.doi.org/10.3201/eid2102.141363.

4. Heang V, Yasuda CY, Sovann L, Haddow AD, Travassos da Rosa AP, Tesh RB, Kasper MR. 2012. Zika virus infection, Cambodia, 2010. Emer Infect Dis 18:349-351. http://dx.doi.org/10.3201/eid1802.111224.

5. Oehler E, Watrin L, Larre P, Leparc-Goffart I, Lastere S, Valour F, Baudouin L, Mallet H, Musso D, Ghawche F. 2014. Zika virus infection
B. complicated by Guillain-Barre syndrome—case report, French Polynesia, December 2013. Euro Surveill 19:20720. http://dx.doi.org/10.2807/1560 -7917.ES2014.19.9.20720.

6. ECDC. 10 December 2015. Rapid risk assessment: Zika virus epidemic in the Americas: potential association with microcephaly and Guillain-Barré syndrome. European Centre for Disease Prevention and Control, Stockholm.

7. WHO. 2015. Zika virus outbreaks in the Americas. Wkly Epidemiol Rec 90:609-610.

8. Lindenbach BD, Murray CL, Thiel HJ, Rice CM. 2013. Flaviviridae, $\mathrm{p}$ 712-746. In Knipe DM, Howley PM (ed), Fields Virology vol 1, 6th ed, vol 712-746. In Knipe DM, Howley PM (ed), Fields
1. Lippincott Williams \& Wilkins, Philadelphia. 


\title{
Zika virus in the Americas: Early epidemiological and genetic findings
}

\begin{abstract}
Nuno Rodrigues Faria, U* Kaimunda do Socorro da Silva Arevedo, "Moritz U. G. Kruemer,' Kenato Souza,

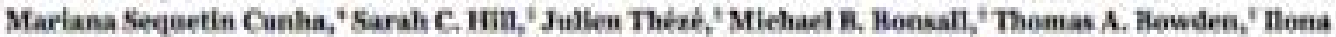
Dissanes, ' Iray Marla Peeco,' Jullana Silva Nogueira, 'Adriana Vurika Maeda, "Fernanda Glseli da Silva Vasami, ' Fernande Lnit de L.ima Macedo,' Akemi Sumbd,' Suell Guerreiro Rodrigues, 'Ana Ceeilia tibeiro Cruz,' itrune Tardeli Nunes,' Daniele Barhosa de Almeida Medeiros,' Daniela Suell Guerreire Rodrigraes,' Alice Louise Nunes Queired, 'Elana Vleira Pinto da Stva,' Daniele Freitas Henriques,' Elisabeth. Salle Travassos da

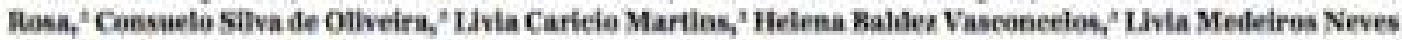
Casweh, ' Darlene de ilrito Simith,' Jane P. Mtessina, '.' Leandro Abude," Jose Lourenço, 'Luir Carios Junior

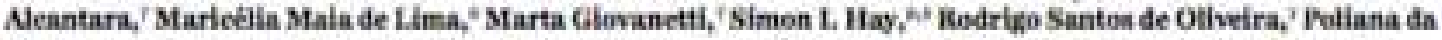

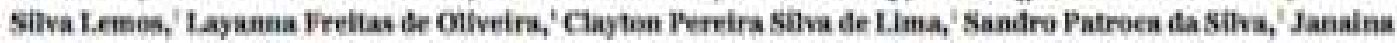

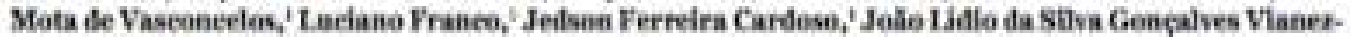

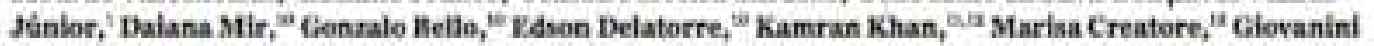

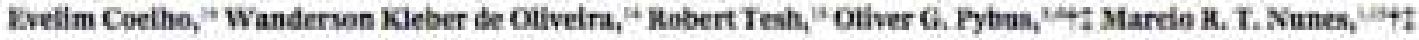
PedreF.C. Vaseonesles't:
\end{abstract}

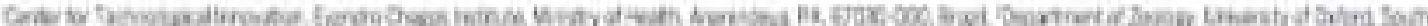

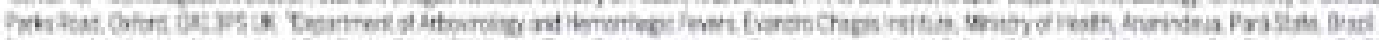

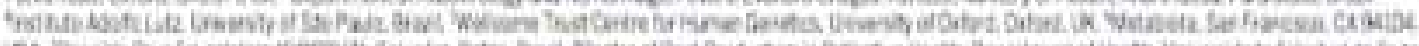

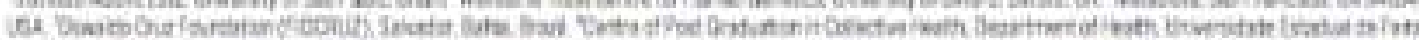

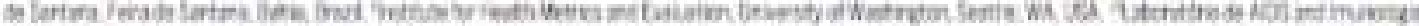

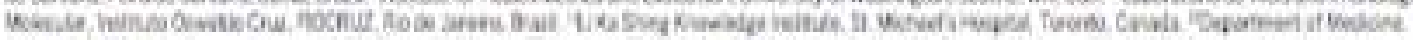

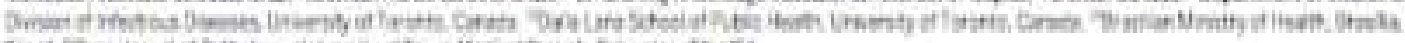

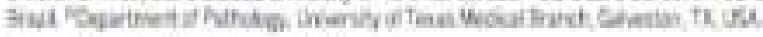

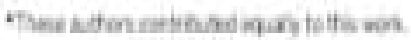

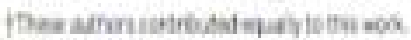

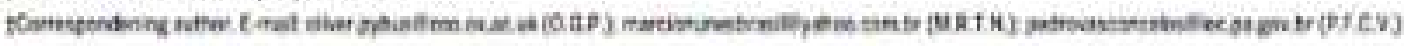

Brazil has experienced an unprecedented epidemic of Ziha virus (ZiKV), with -30.000 cases reported to date. ZIXV was first defected in Drazil in Mary 2015 and cases of microcephaly potentially associated with Z1KV infection were identified in Novenber 2015. Using next generation sequencing we generated seven Braz lian ZIKV ganomes, sanpled from four seif limited cases, one blood donor, one fatal adult case, and one newborn with microcephaly and congenital malformations. Phylogenet ic and molecular clock analyses show a single introduction of ZIKV into the Americas, estimated to have occurred between May-Dec 2013. more than 12 months prior to the detection of ZIXV in BrazI. The estimated date of origin coincides with an increase in air passengers to Brazil from ZIKV endemic areas, and with reported outbreaks in Pacific Islands. ZIKV genemes from Brasil are phylogenetically interspersed with those from other South American and Caribbean countries. Mapping mutations onto existirg structural models revealed the context of virat amino acid charges present in the outbreak lineage: however no shared amino acid changes were found among the three currently available virus genemes from microcephaly cases: Municipalify-ievel incidence data indicate that roports of suspected mictocephaiy in Brazi best correlate with ZIKV incidence around week 17 of pregnancy, although this does not demonstrate cousation, Out genetic description and aralysis of ZIKV isolates in Hrazit provide a baseline for future studies of the evolution and molecular epidemiology in the Americas of this emerging virus.

Zika virna (nXV) la a single ittacdect, ponitive-netse XNA virut with a $104 \mathrm{~Kb}$ geneme entuding a single pobprotet that is cleaved inta three strietural pecteins $\left(\mathrm{C}_{\mathrm{i}}\right.$ pr M/M, $\mathrm{m}$

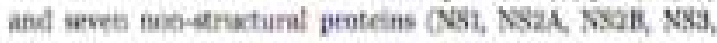

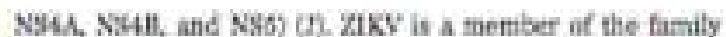

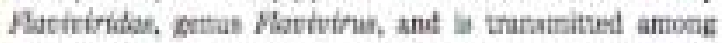

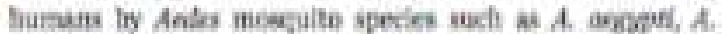

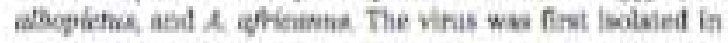


WW fun a sentirel rhesu mincky in the aku boret tr

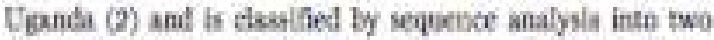

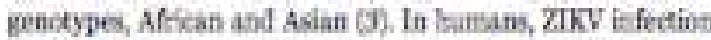

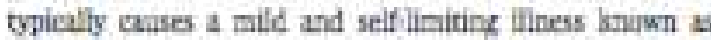

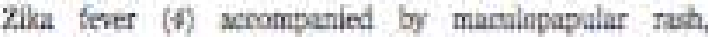

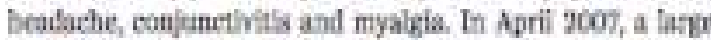

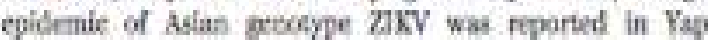

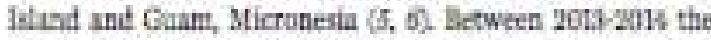

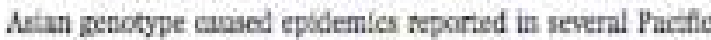

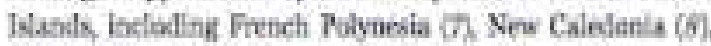

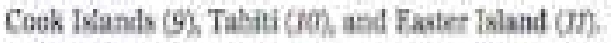

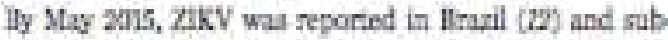
sequently in several cuontrie of South and Centril Amerias.

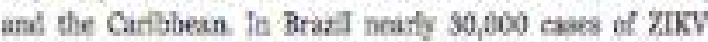
tofection byd ben notithet by Joth Jan now wupplemen

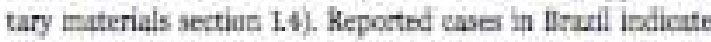

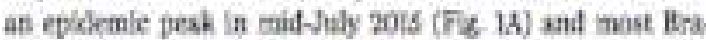

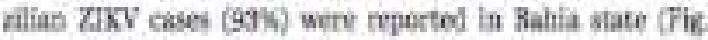

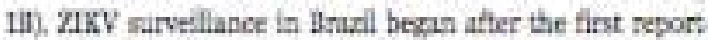
ed lowilim ane and te condocted tirolach the nathanal so

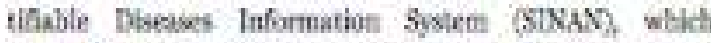

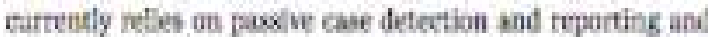

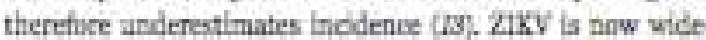

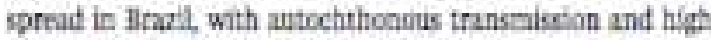

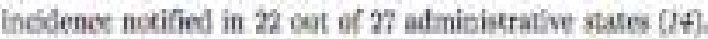

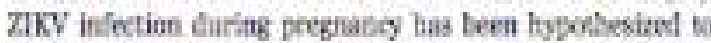

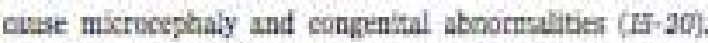

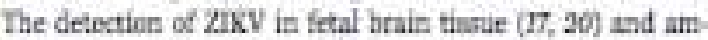

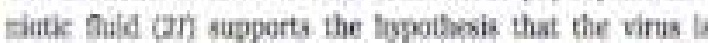

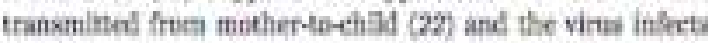

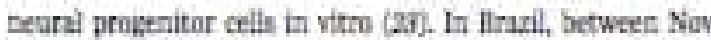

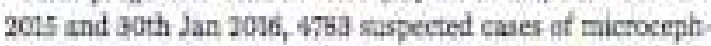

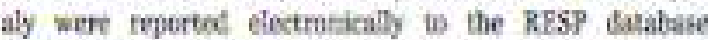

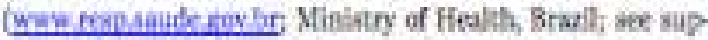

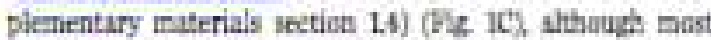
movethd case are still under anvetzation ard a simit

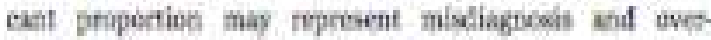

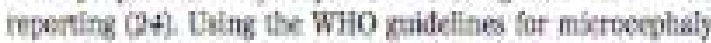
tivposs provibed an the the Murch 2036 (25) we ident

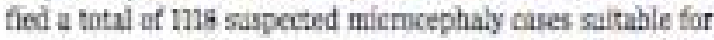

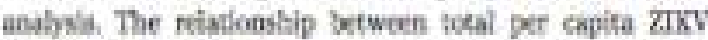

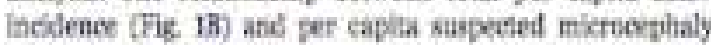

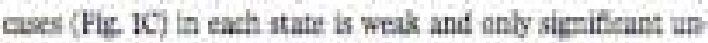

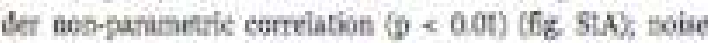

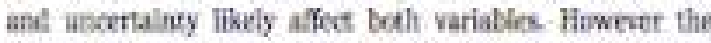

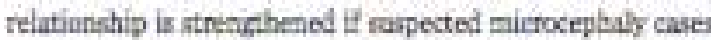

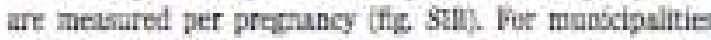

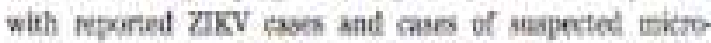

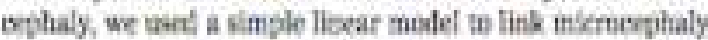

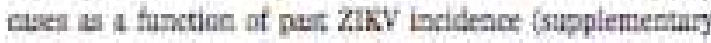

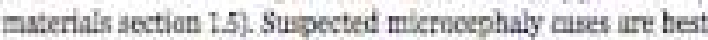

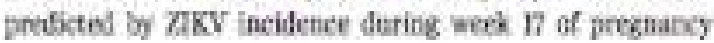

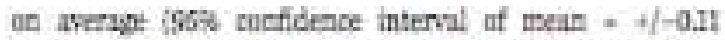

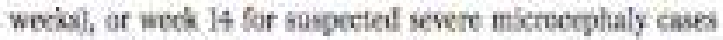

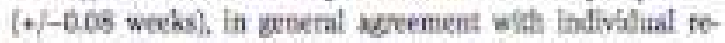
pors of the taine of ZIKV gompturs in mithers of mino

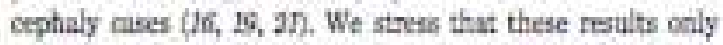

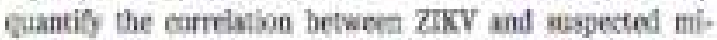

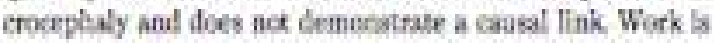

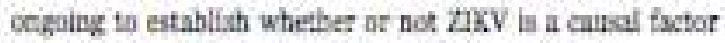

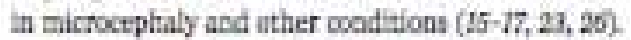

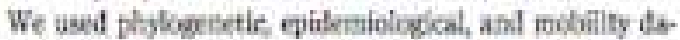

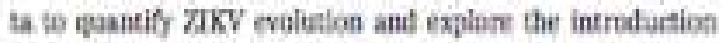

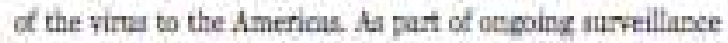
by the Brallian Stritry of Health, notanal Iahientaries,

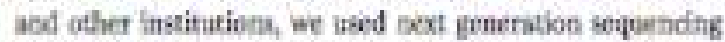

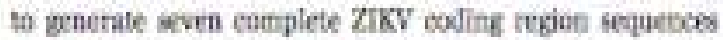

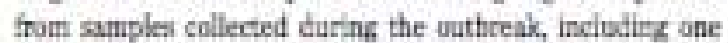

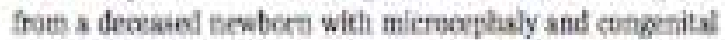

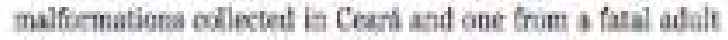
cae with lupa und themaind diseise tom Mananho

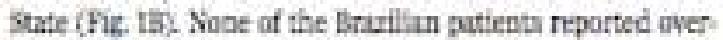

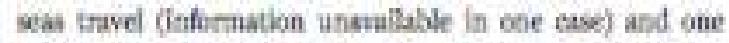

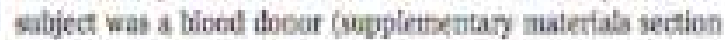

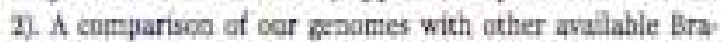

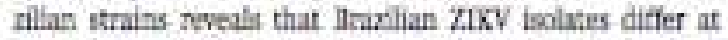

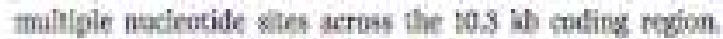

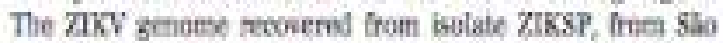

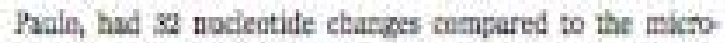

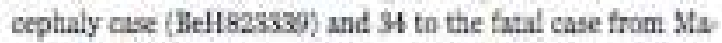

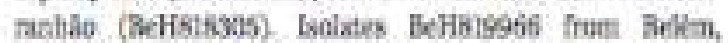

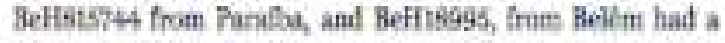
maxmom of 5 noclentite chanpel.

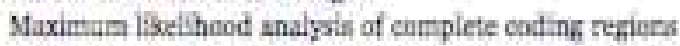

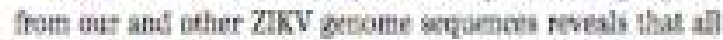

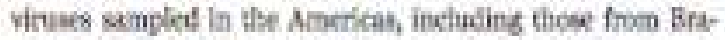
ah, tarm a robat Eanophyicte churer (boototup wore -

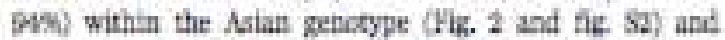

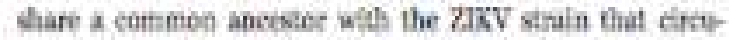

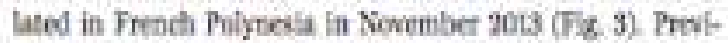

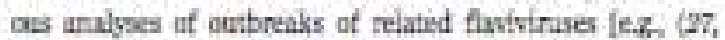

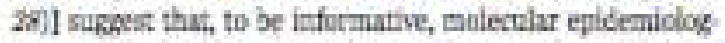

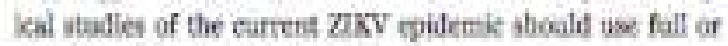

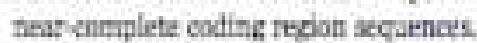

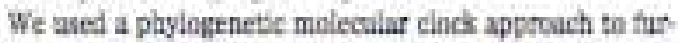

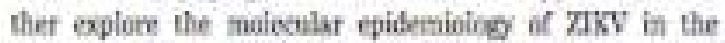

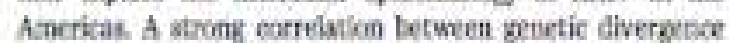

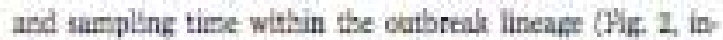

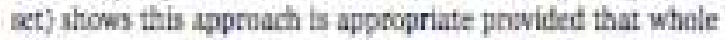

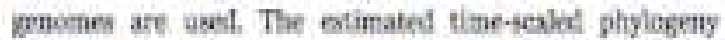

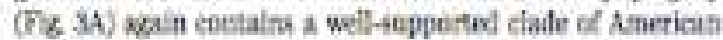

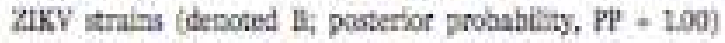

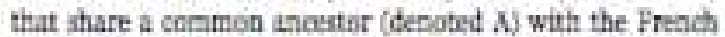

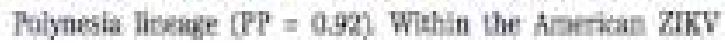




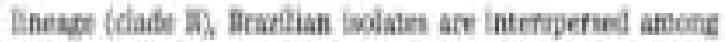

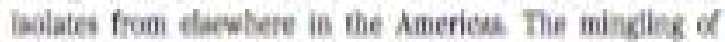

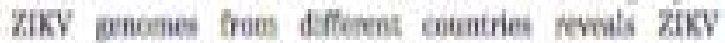

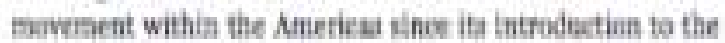

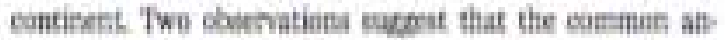

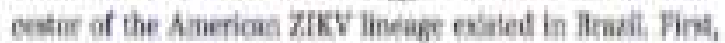

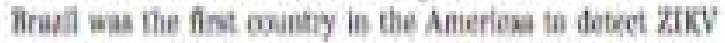

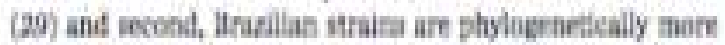

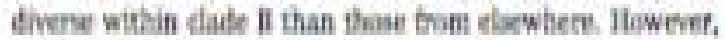

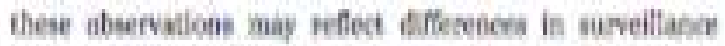

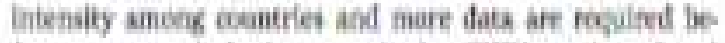

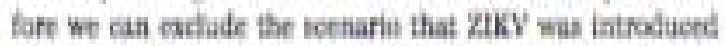

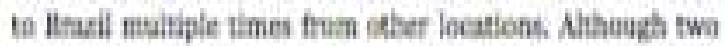

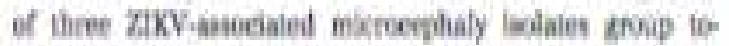

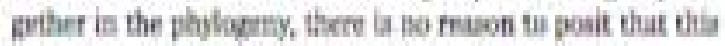

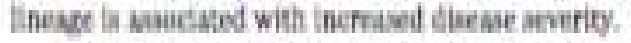

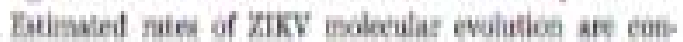

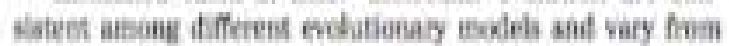

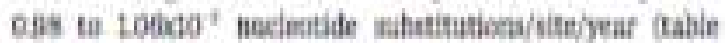

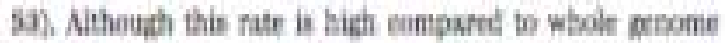

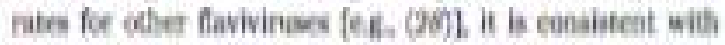

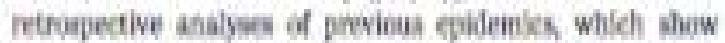

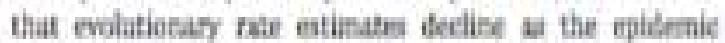

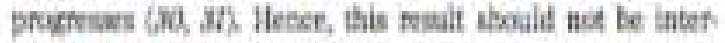

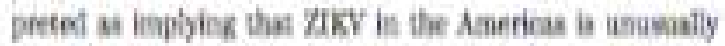

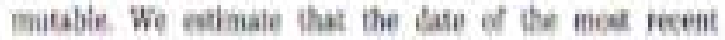

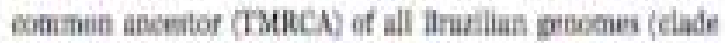

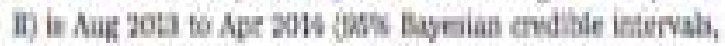
Ifti

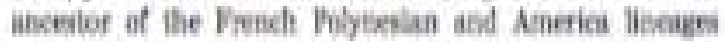

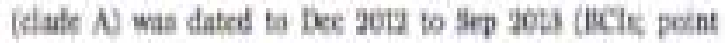

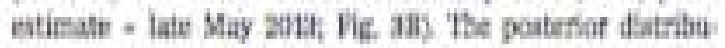

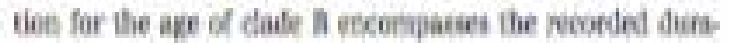

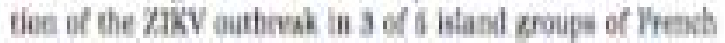

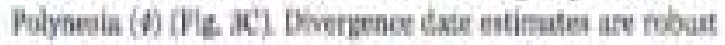

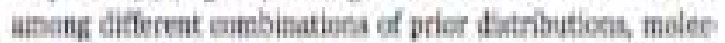

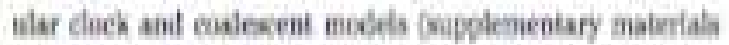

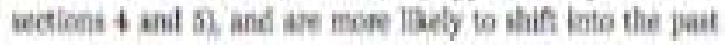

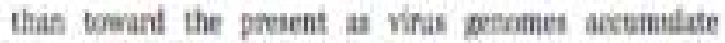
thruath une (in)

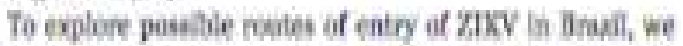

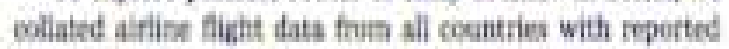

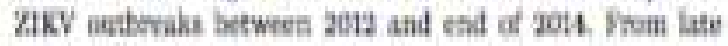

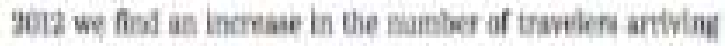

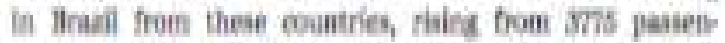

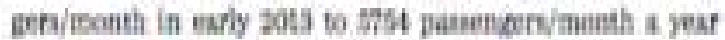

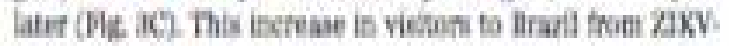

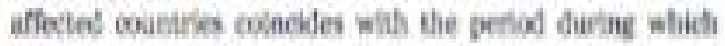

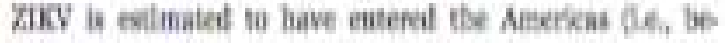

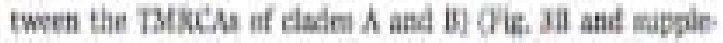

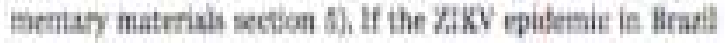

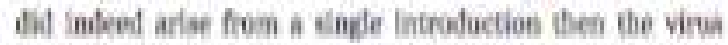

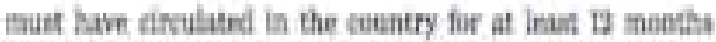

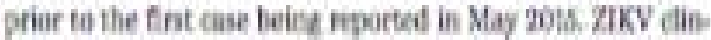

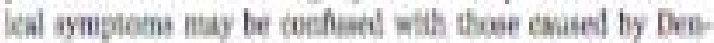

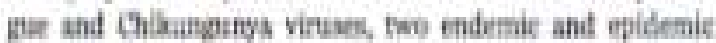

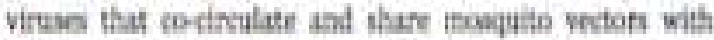

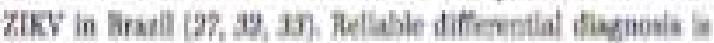

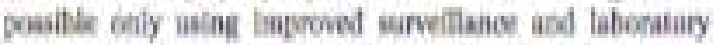

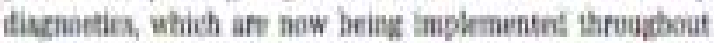
the wouthy

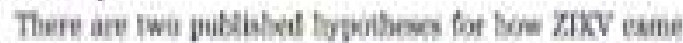

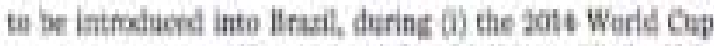

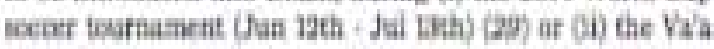

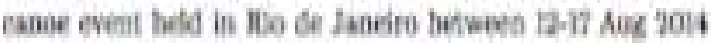

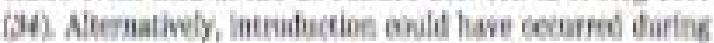

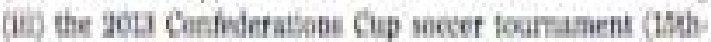

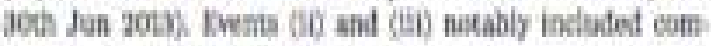

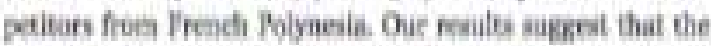

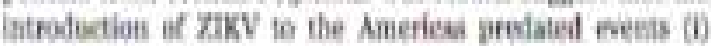

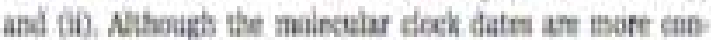

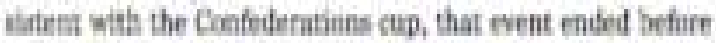

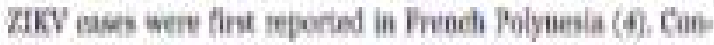

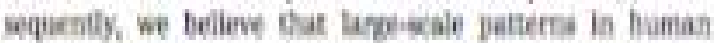

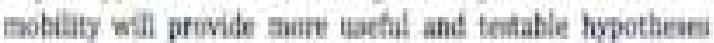

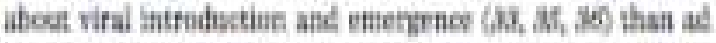

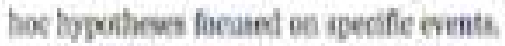

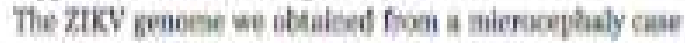

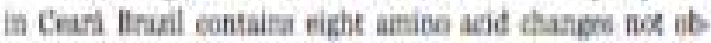

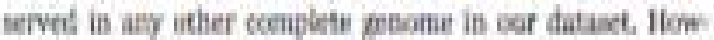

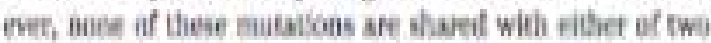

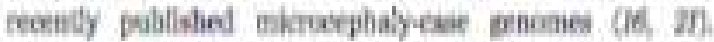

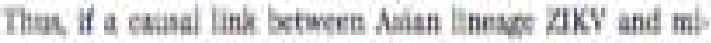

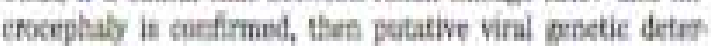

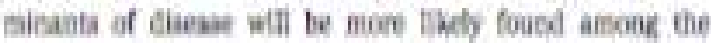

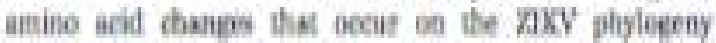

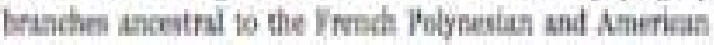

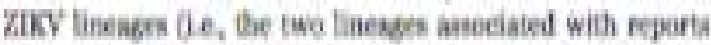

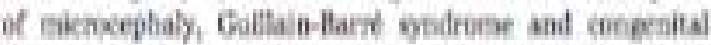

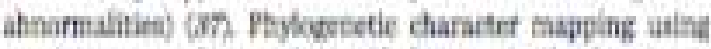

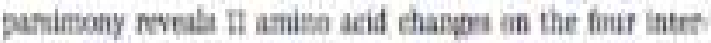

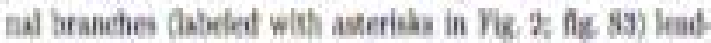

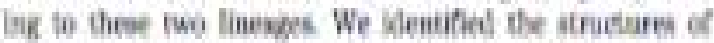

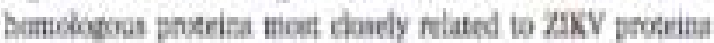

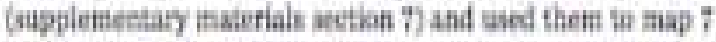

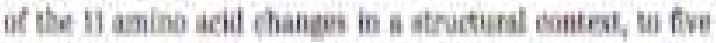

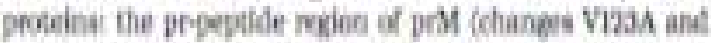

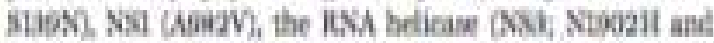

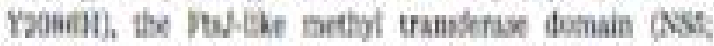

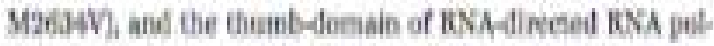

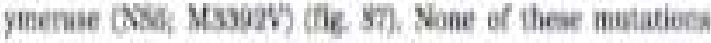

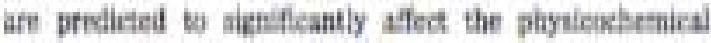

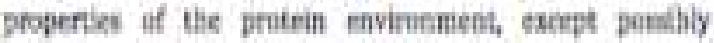

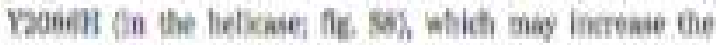


http://dx doi.org/10.1016/j.stem.2016.02.

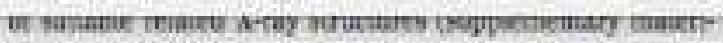

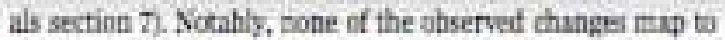

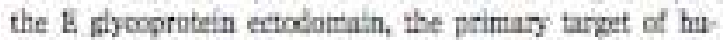

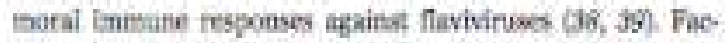

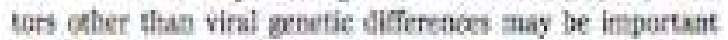
bor the proposed pathrgenes of hXV; hypothesizd tietors

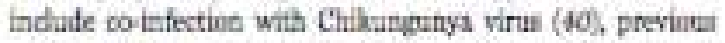

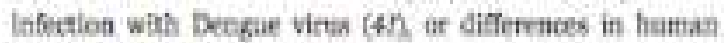

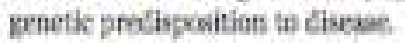

Heides vecto borne and muthen to chlld tramingion,

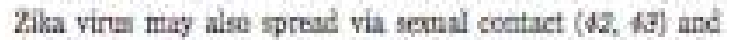

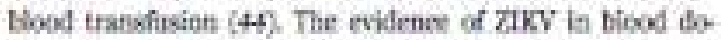

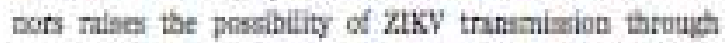

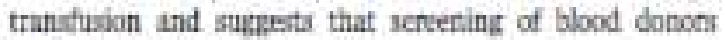

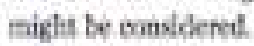

\section{PEFEREALES AND WOTES}

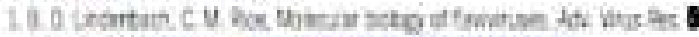

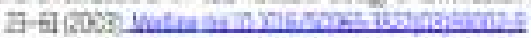

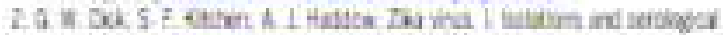

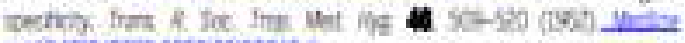

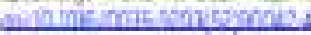

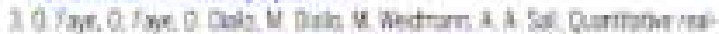

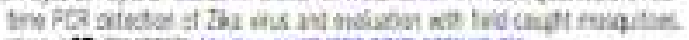

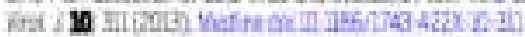

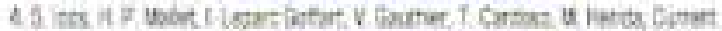

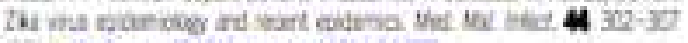

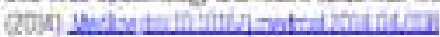

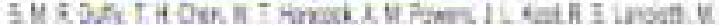

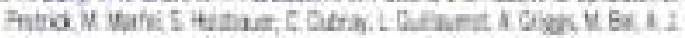

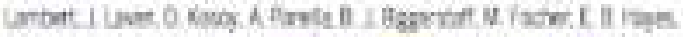

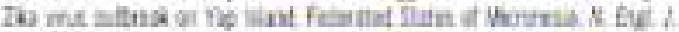

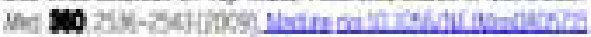

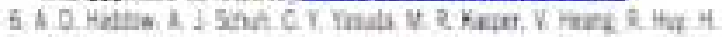

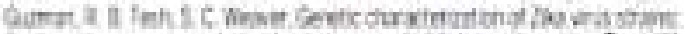

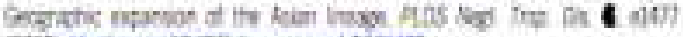

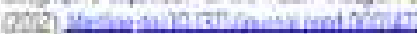

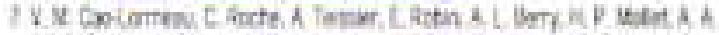

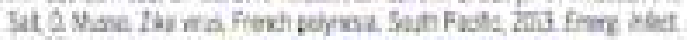

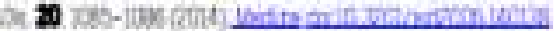

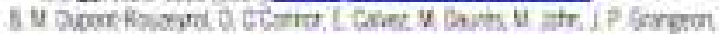

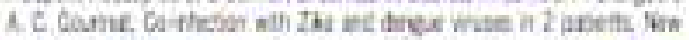

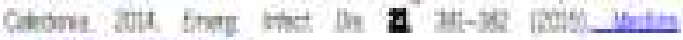

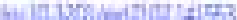

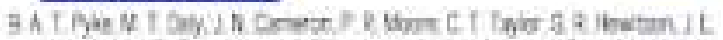

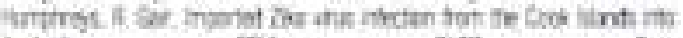

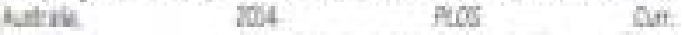

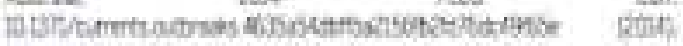
Hide

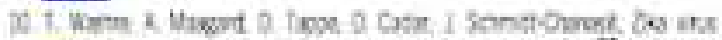

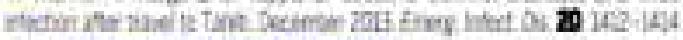

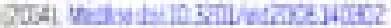

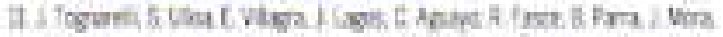

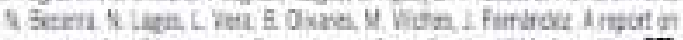

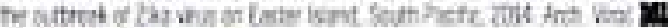
프 seaphHn

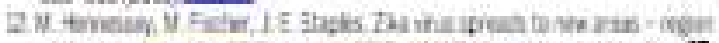

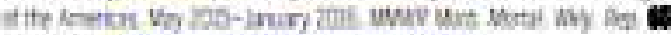

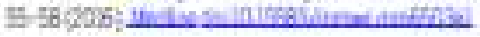

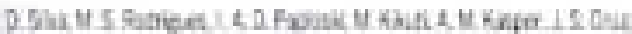

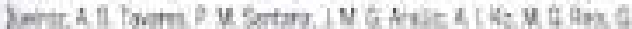

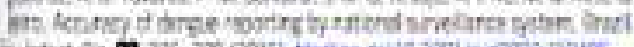

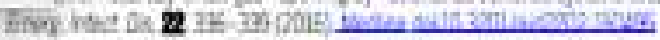

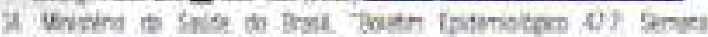

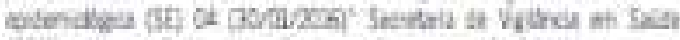

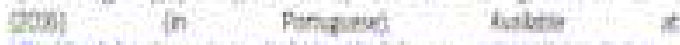

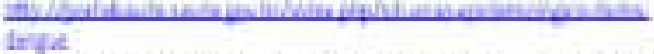

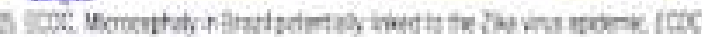
Mis

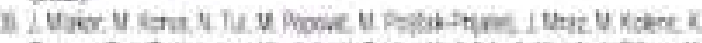

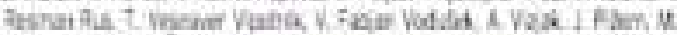

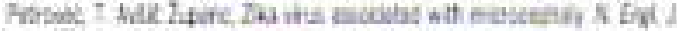

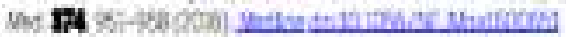

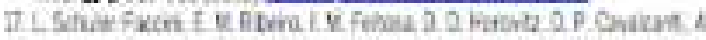

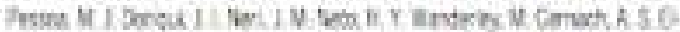

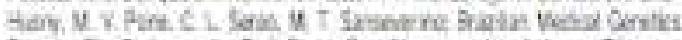

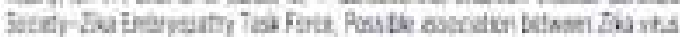

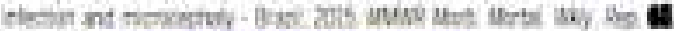
\$av

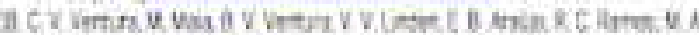

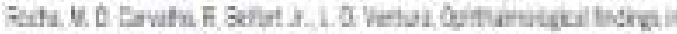

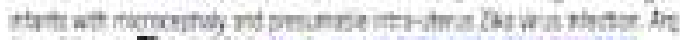

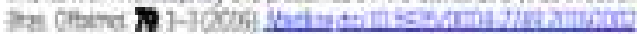

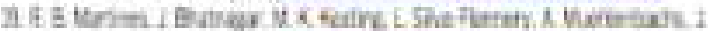

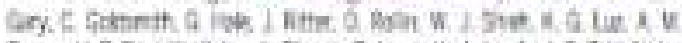

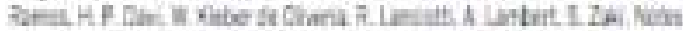

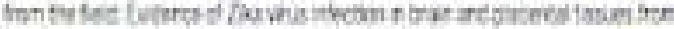

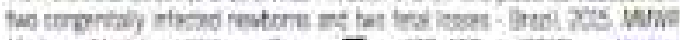

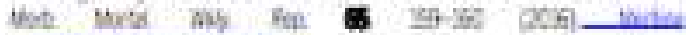

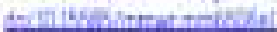

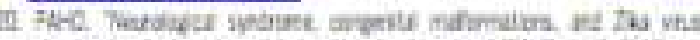

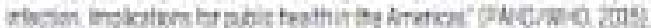

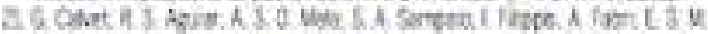

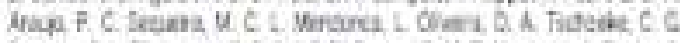

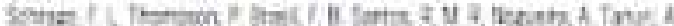

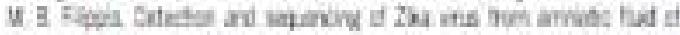

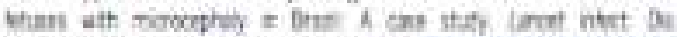

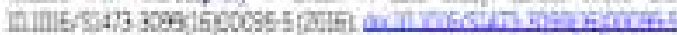

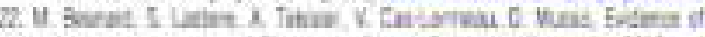

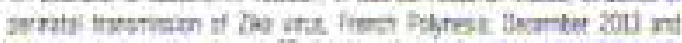

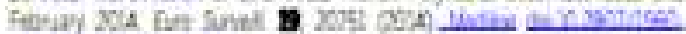

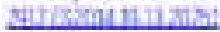

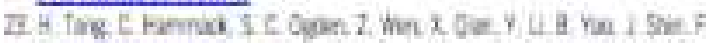

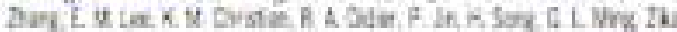

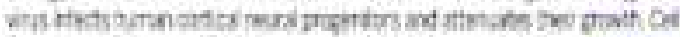

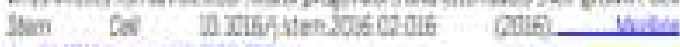
1.

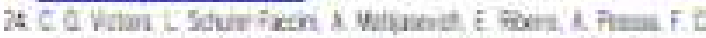

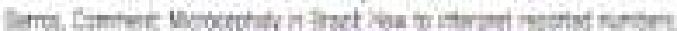

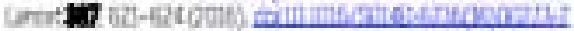

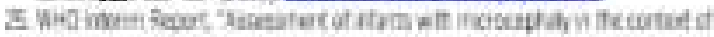

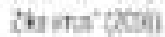

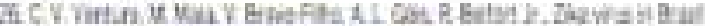

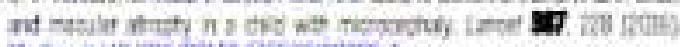

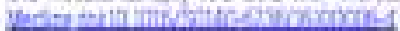

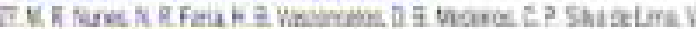

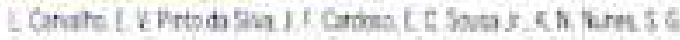

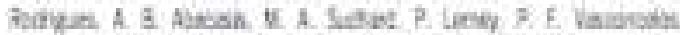

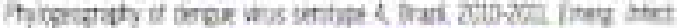

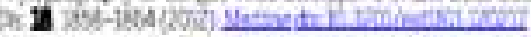

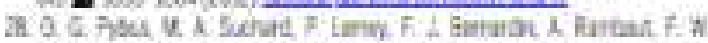

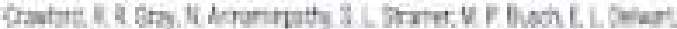

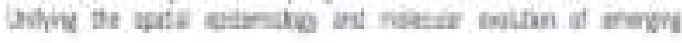




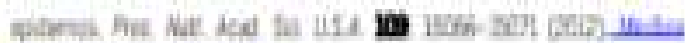

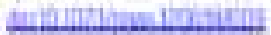

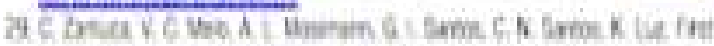

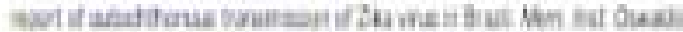

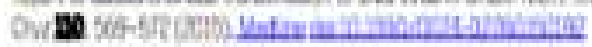

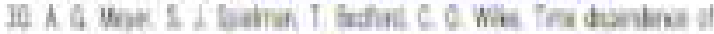

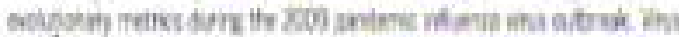

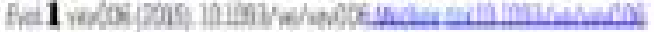

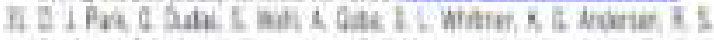

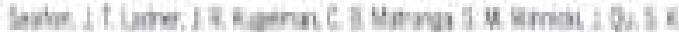

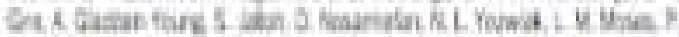

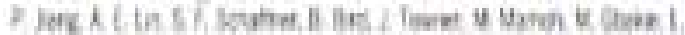

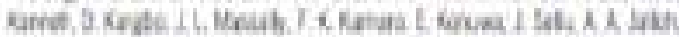

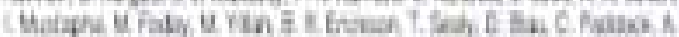

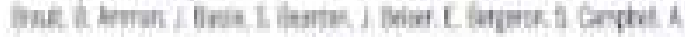

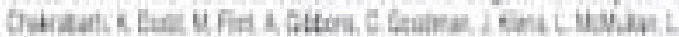

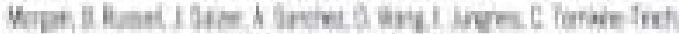

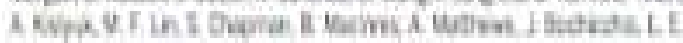

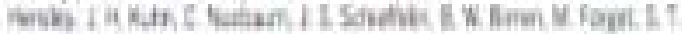

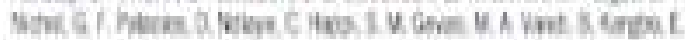

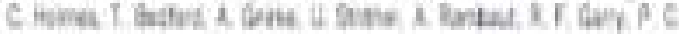

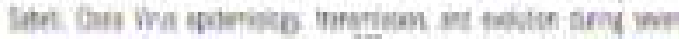

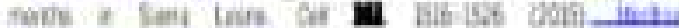

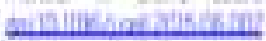

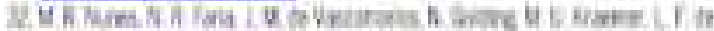

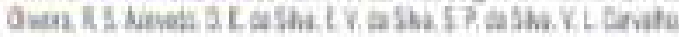

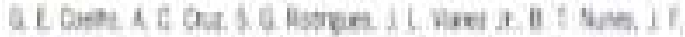

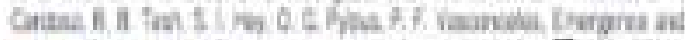

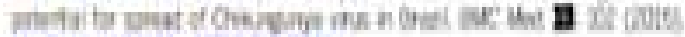

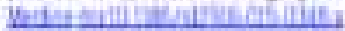

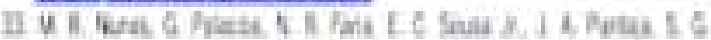

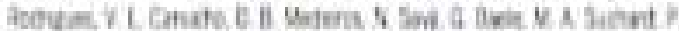

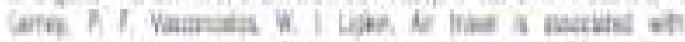

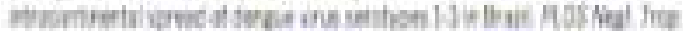

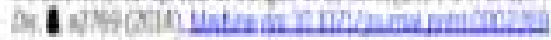

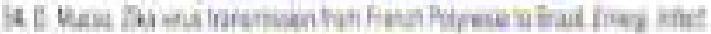

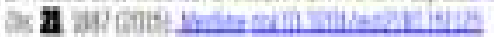

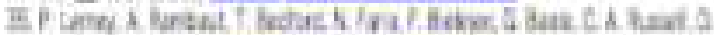

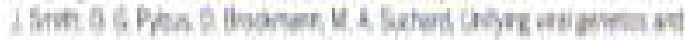

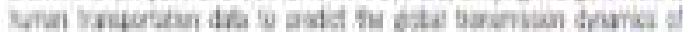

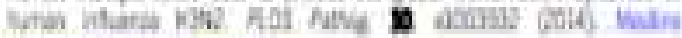

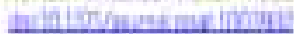

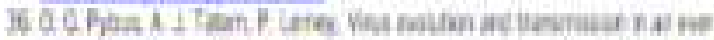

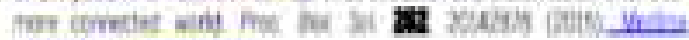

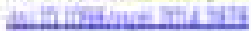

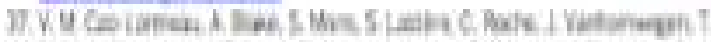

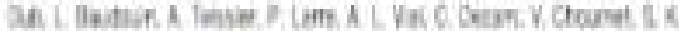

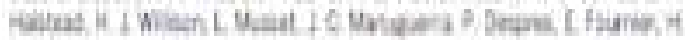

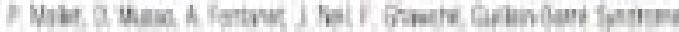

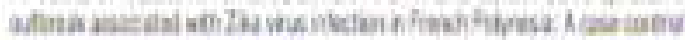

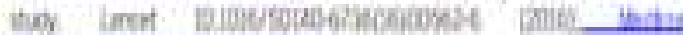

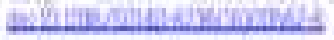

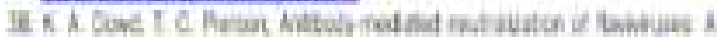

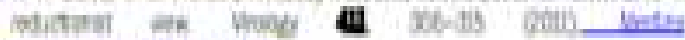

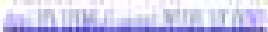

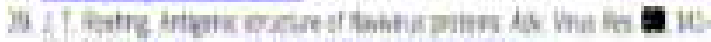

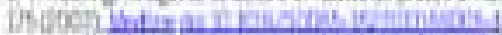

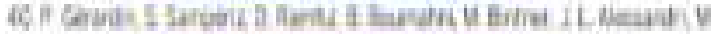

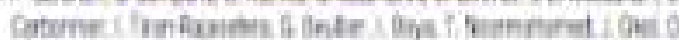

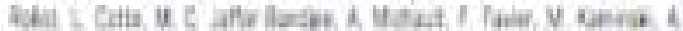

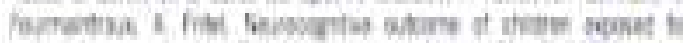

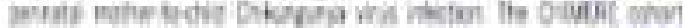

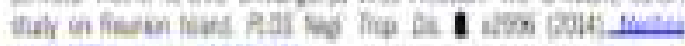

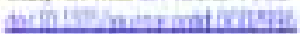

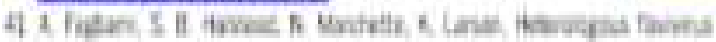

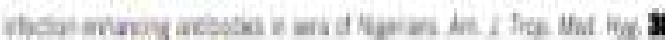

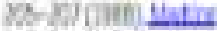

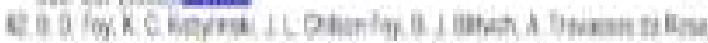

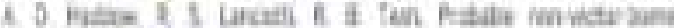

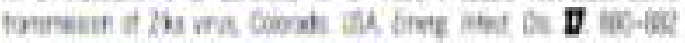

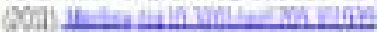

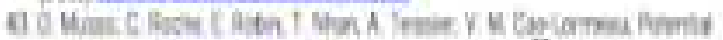

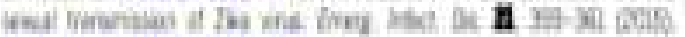

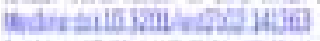

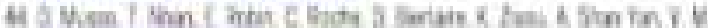

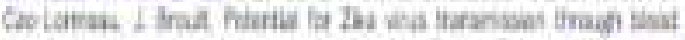

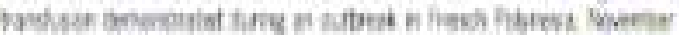

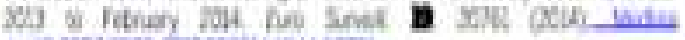

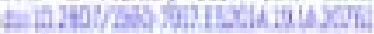

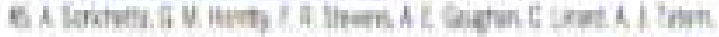

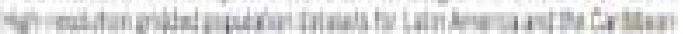

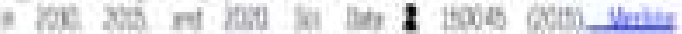
-

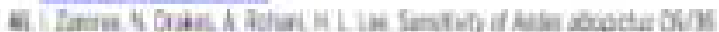

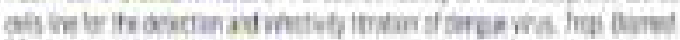
A 117 Tithintur

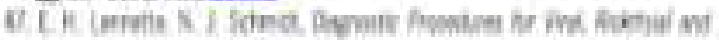

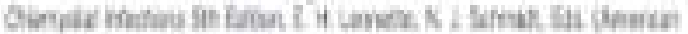

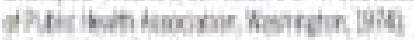

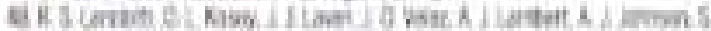

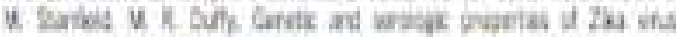

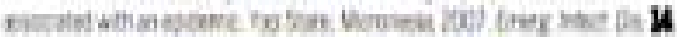

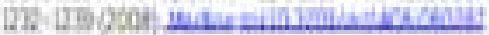

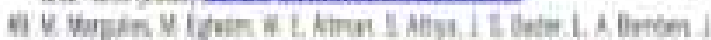

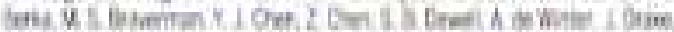

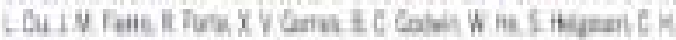

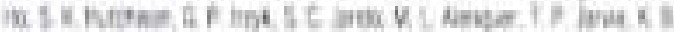

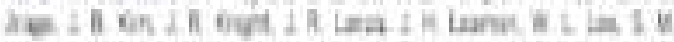

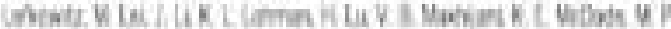

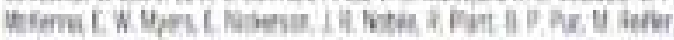

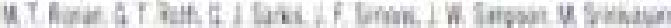

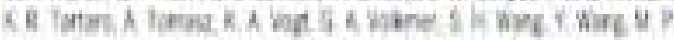

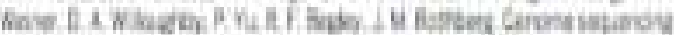

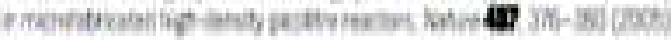
Hine

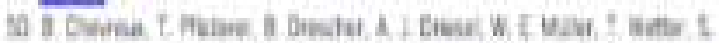

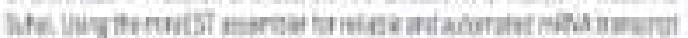

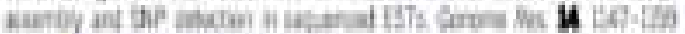

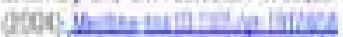

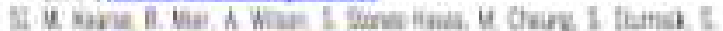

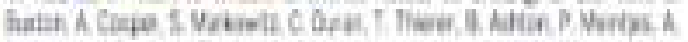

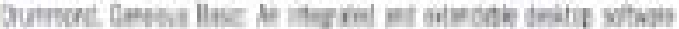

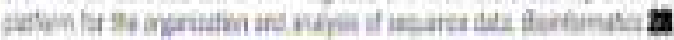

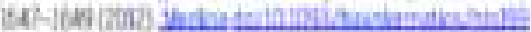

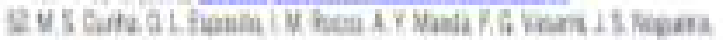

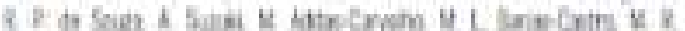

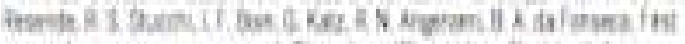

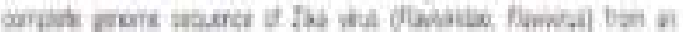

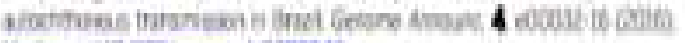

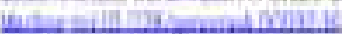

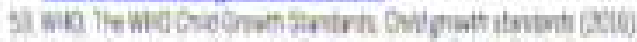

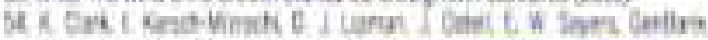

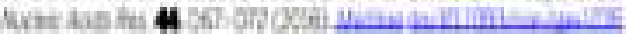

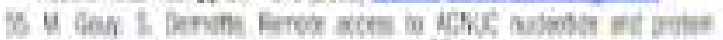

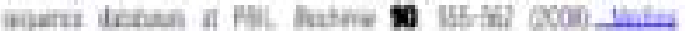

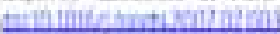

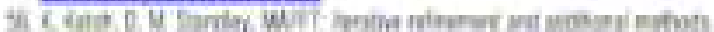

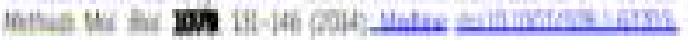
Hillis

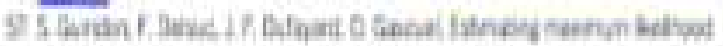




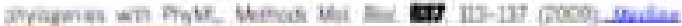

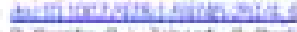

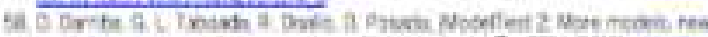

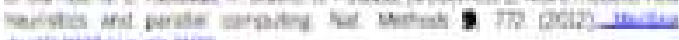

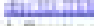

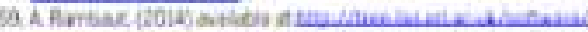

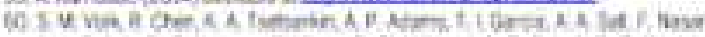

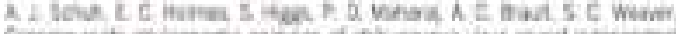

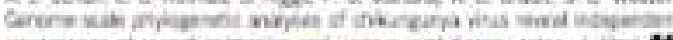

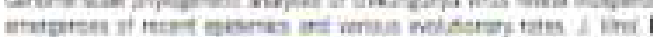

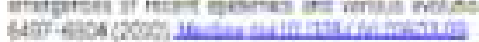

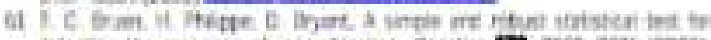

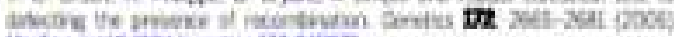

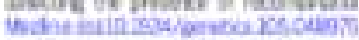

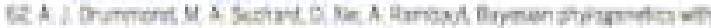

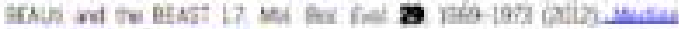

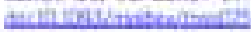

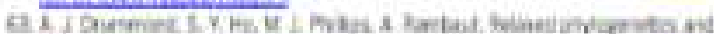

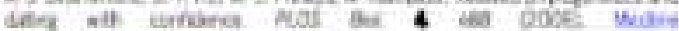

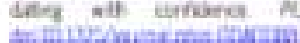

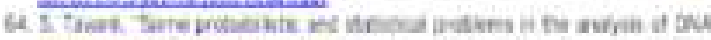

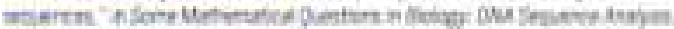

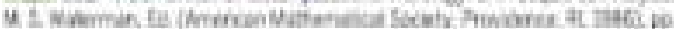
5).

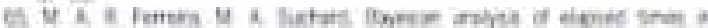

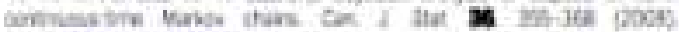

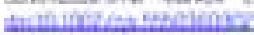

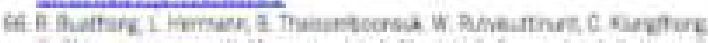

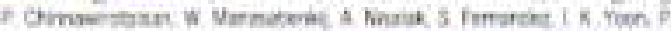

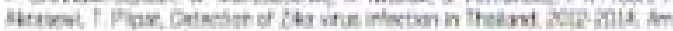

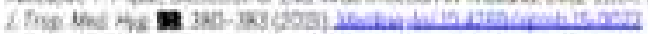

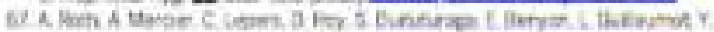

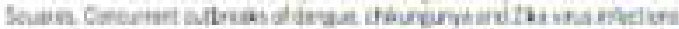

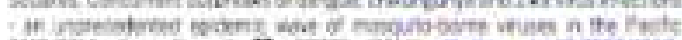

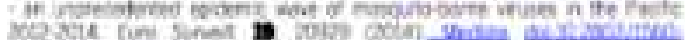
Dexit foni sonet

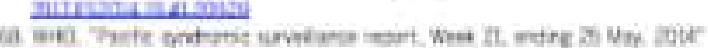

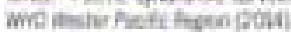

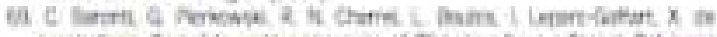

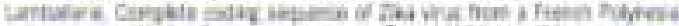

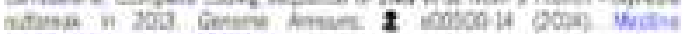

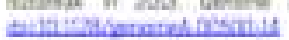

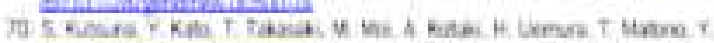

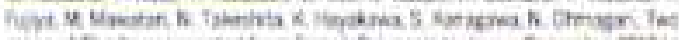

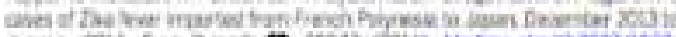

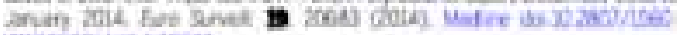

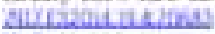

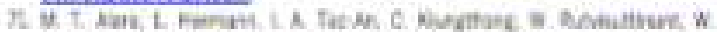

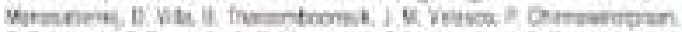

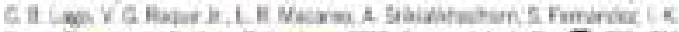

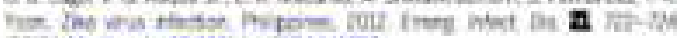

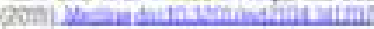

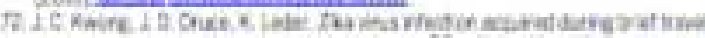

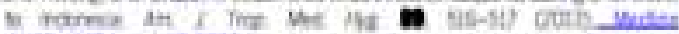

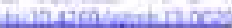

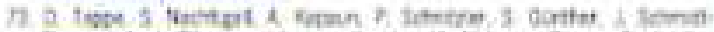

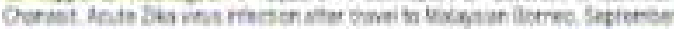

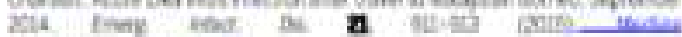

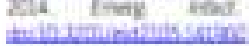

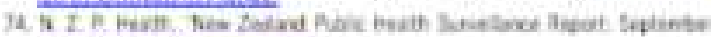
zerovitan

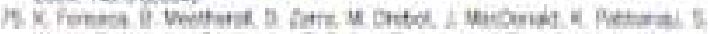

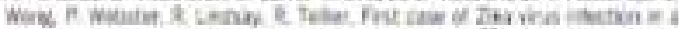

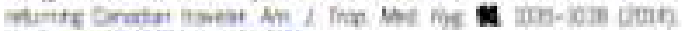

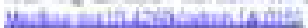

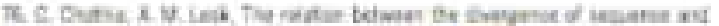

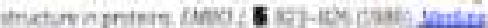

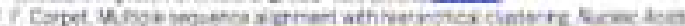

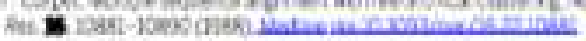

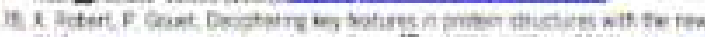

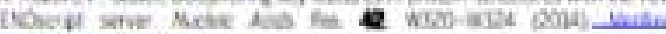

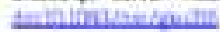

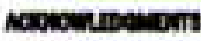

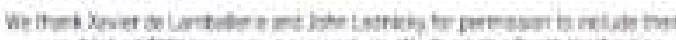

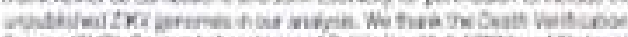

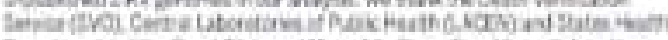

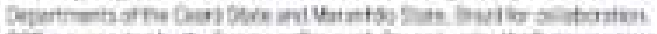

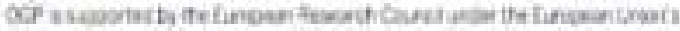

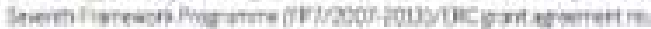

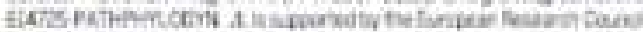

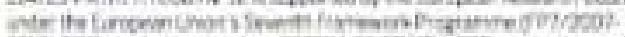

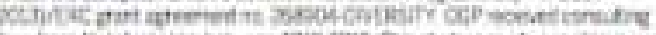

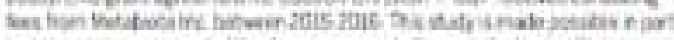

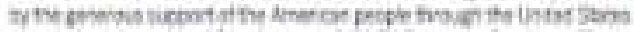

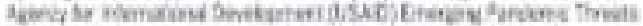

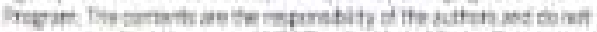

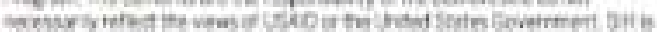

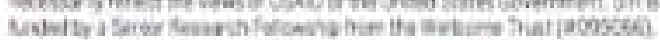

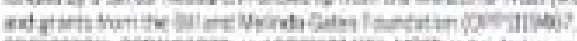

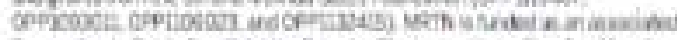

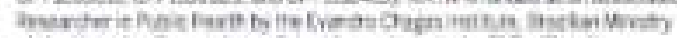

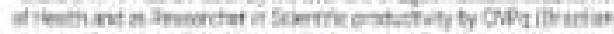

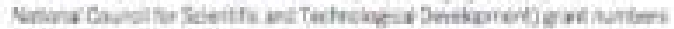

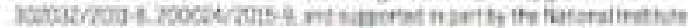

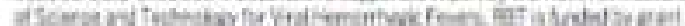

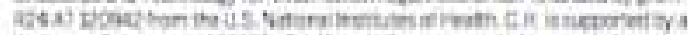

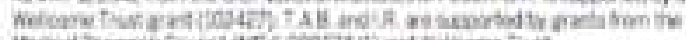

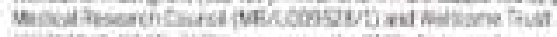

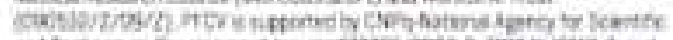

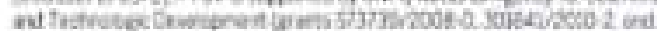

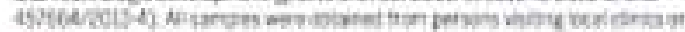

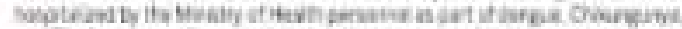

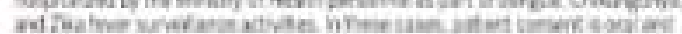

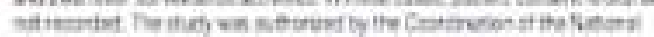

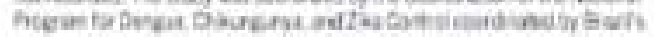

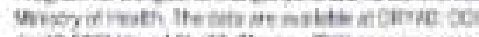

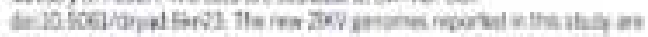

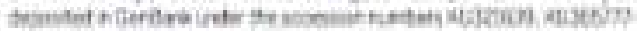

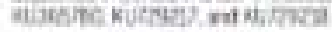

\section{SUPpt ENENTARY MaTEALALS}

Unminat beint

Seserestay tat

lermitiols

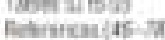

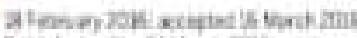

Nanted mire it vert ant

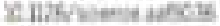


A

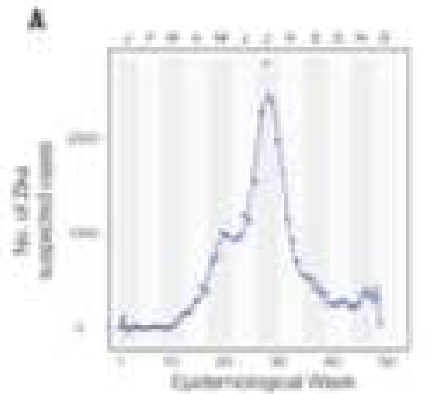

(3)

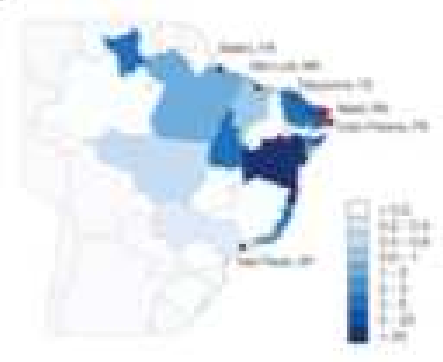

c

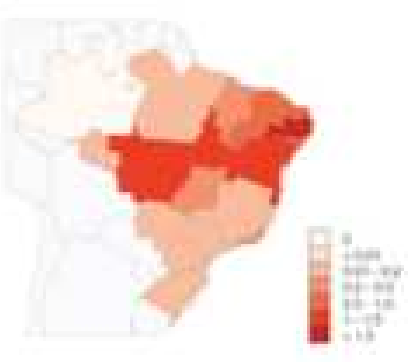

Fe 1 Tme series and cartegraphy of reported Zilea vinus and microcephaly cases in Brazll. (A) Number of notified cases of 2 KV (bi.je) in 5596 municipaltips in Brazil, per week, which peaked in 12.18 July 2015 (n $=279 t$ cases). (B) Total incidence of ZKV cates per 100,000 peaple it each federal state, Triargies indicate sarroling locations of the sequerices reootted bere; circles indicate focations of other genomes trom Brazi [municipaity of Natai in Ric Grance do Norte state $(10)$ and an unevewn municipaity in Paraiba state [21)] Red symbols irvicate ZiKV genomes isolated from microcephaly cases. Federal states are indicated by 2-etter codes: PA: Para, MA: Marannäa, CE: Ceara. RN: Rea Grande do Norte PB: Paraba. Per capita incidences in wach state were caloulated isirg hovresouticn gridded burnan populat on size datasets for Brazl (45). (C) inodence-co sispected m crocephaly cases per 100.000 pecplie in eoch fecteral state. Per easita incidences for each state ware calculated a isescribed for panei (B). 


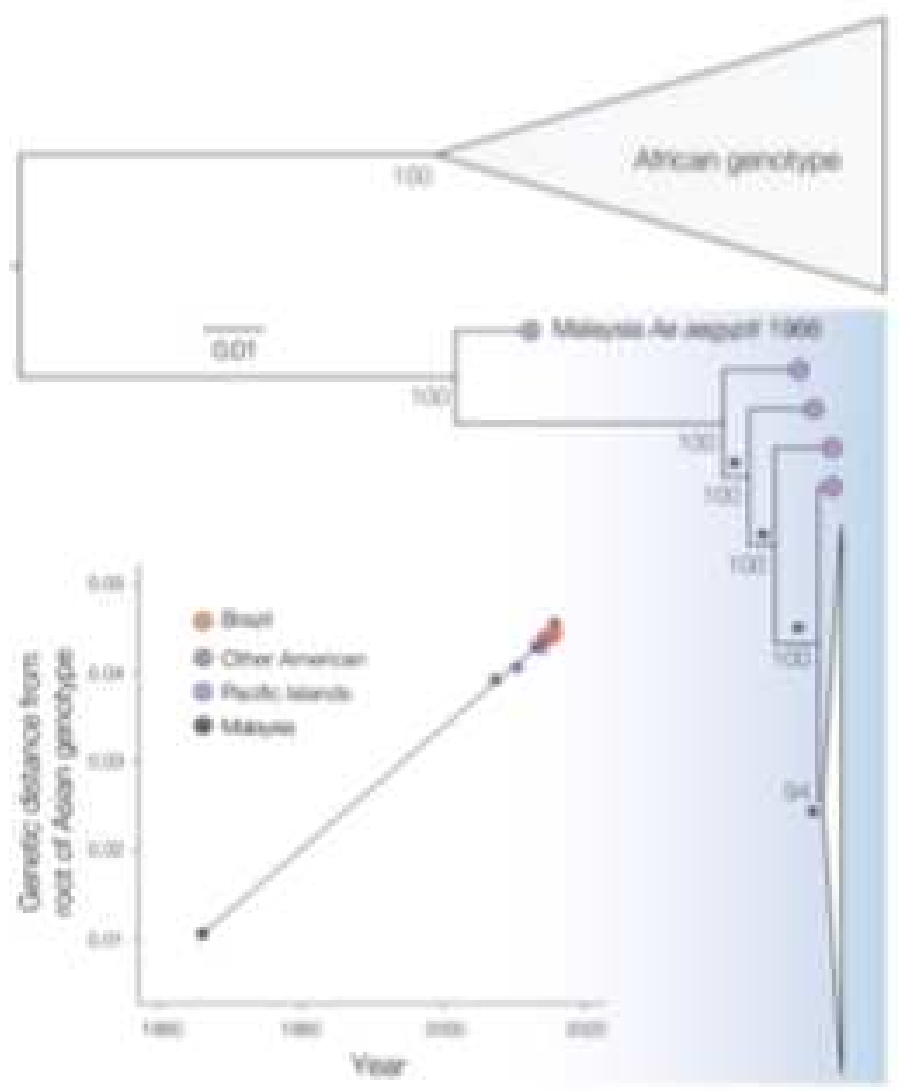

Fe. 2. Mandmum Ilkallhood phylogeny of ZIKV complate codine reclon sequencea. Boetstiap scores art stown next to welstupported nedes and thet phylogerny was mid-pont rootind A fult arnotated tree is provided in te. S2. The American ZKX outbreah ciace is drawt as a white trange and is shown in detail in $r g$. 3 . Asterisks bevight the fou internai branches that are

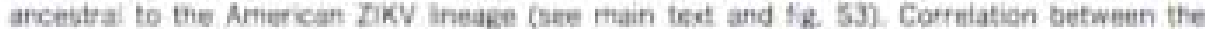
samping date of each secuerce and the gnnetic distance of trat seasence frem then foot of a maximum ikeincod phylognny of the Asian genotype $\left\langle F^{2}=0.097\right)$ A motecutar clock phylogery

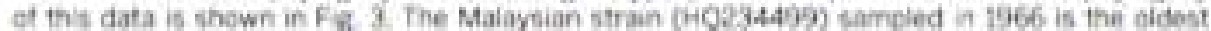
mprosentative of that geriotype and falis on the reeretaion lire. indcatirg that it does not apoeir

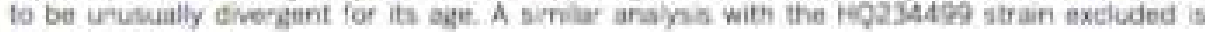
shown in fie Ssc: 
$\mathbf{A}$

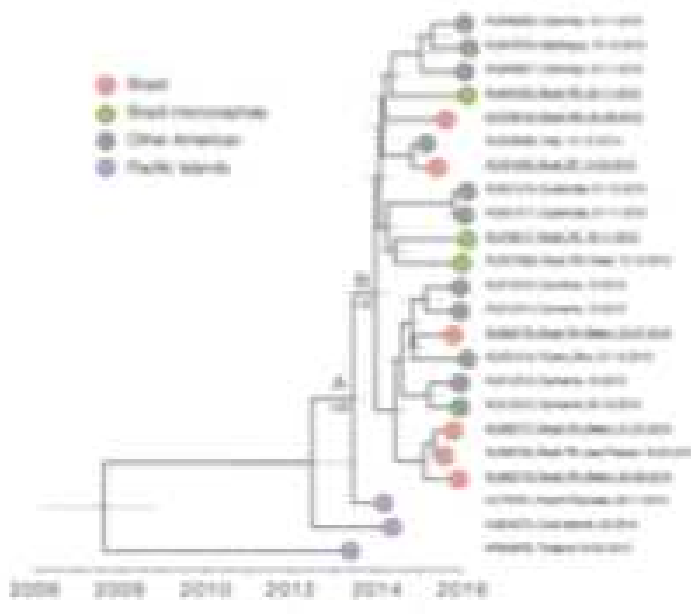

c

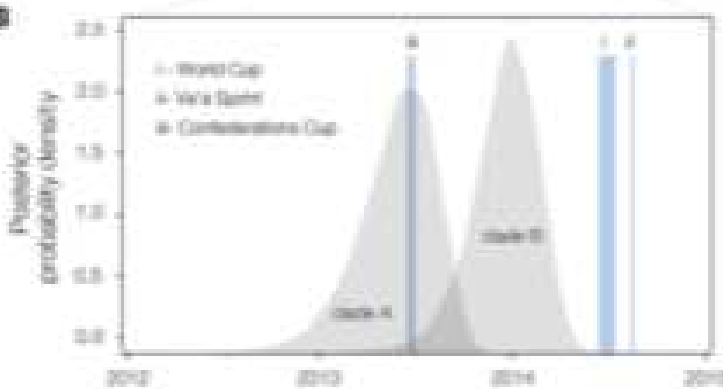

c

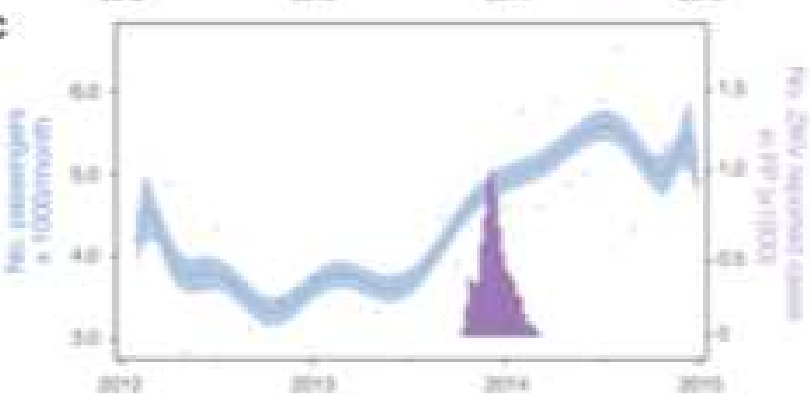

Fie. 3. Timescale of the introduction of ZiKV to the Americss. (A) Noiecular clock ohylogery of the ZIKV butoreas lineage estirnated from eorralete codict rexian sequences, plis 6 secuences (KJ6342)3. Kis12335 Ku3t2314. KLR12313, KU646828. and KU646827 iarger Enan 1500nt (asalabie dals is of 7 th March 2016) For visual clar ty. theee dasal secuences, HQ23499 (Maiaysia. 1966) Eus45988 (Micronesia. 2007) and JN860885 (Combodia. 2010) are not displayed here (see fig. 53) Gray horizontel bars epprasert $95 \%$ Bayesian cred yle atervals for divergence dates. A and $A$ denote claibes tiscussed in main text arid nutribers next to them denote postericr prababihtes. Diamand sizes represent, at each node. the posternor probanility supcort of that node. Taw are abeled with accesson number, sarnpling acation, and sampling date. Nanes of secuances generated in this stidy are underlined ( $\mathbf{B}$ ) Postersor distributions of the ustimated ages (TMRCAs) of clades $A$ and $B$, ustirated in BEAST using wnder the best fitirg evolutionary model (tabin S2). The time and curation of the three ewents $(1)+i v)$ discissec an the main text ate showh. (C) The the curve (lePt fiand axis) shows a polynomial fittris of the number of travelers (bue points) from countries with reccrded $2 \mathrm{KV}$ cutbrease between 2012 and 2015 (French Polynesia, Thailard. Indonesia. Masysia, Cambodia, New Caledoriat. supplementary matariais section 6), ageregated across 20 Brazliat national arports. The purpie tors represent weekly rirnters of susstected ZKV cases (right hand side) in Frarch Pelnesia fram the 30 Oct 2013 to 14 Feb $2014(4)$. 


\section{Science}

\section{Zika virus in the Americas: Early epidemiological and genetic findings}

Nuno Rodrigues Faria, Raimunda do Socorro da Silva Azevedo, Moritz U. G. Kraemer, Renato Souza, Mariana Sequetin Cunha, Sarah C. Hill, Julien Thézé, Michael B. Bonsall, Thomas A. Bowden, llona Rissanen, Iray Maria Rocco, Juliana Silva Nogueira, Adriana Yurika Maeda, Fernanda Giseli da Silva Vasami, Fernando Luiz de Lima Macedo, Akemi Suzuki, Sueli Guerreiro Rodrigues, Ana Cecilia Ribeiro Cruz, Bruno Tardeli Nunes, Daniele Barbosa de Almeida Medeiros, Daniela Sueli Guerreiro Rodrigues, Alice Louize Nunes Queiroz, Eliana Vieira Pinto da Silva, Daniele Freitas Henriques, Elisabeth Salbe Travassos da Rosa, Consuelo Silva de Oliveira, Livia Caricio Martins, Helena Baldez Vasconcelos, Livia Medeiros Neves Casseb, Darlene Giovanetti, Simon I. Hay Rodrigo Santos de Oliveira, Poliana, La Silva Lemos, Layanna Freitas de Oliveira Clayton Pereira Silva de Lima, Sandro Patroca da Silva, Janaina Mota de Vasconcelos, Luciano Franco, Jedson Ferreira Cardoso, João Lídio da Silva Gonçalves Vianez-Júnior, Daiana Mir, Gonzalo Bello, Edson Delatorre, Kamran Khan, Marisa Creatore, Giovanini Evelim Coelho, Wanderson Kleber de Oliveira, Robert Tesh, Oliver G. Pybus, Marcio R. T. Nunes and Pedro F. C. Vasconcelos

published online March 24, 2016

ARTICLE TOOLS

SUPPLEMENTARY

RELATED
CONTENT

REFERENCES

PERMISSIONS http://science.sciencemag.org/content/early/2016/03/23/science.aaf5036

http://science.sciencemag.org/content/suppl/2016/03/23/science.aaf5036.DC1

http://science.sciencemag.org/content/sci/351/6280/1377.ful file:/content This article cites 68 articles, 11 of which you can access for free
http://science.sciencemag.org/content/early/2016/03/23/science.aaf5036\#BIBL

http://www.sciencemag.org/help/reprints-and-permissions

Science (print ISSN 0036-8075; online ISSN 1095-9203) is published by the American Association for the Advancement of Science, 1200 New York Avenue NW, Washington, DC 20005. 2017 @) The Authors, some rights reserved, exclusive license American Association for the Advancement of Science. No claim to original U.S. Government Works. The title Science is a registered trademark of AAAS. 